\title{
UTILIZAÇÃO DA SENTENÇA DE IMPROCEDÊNCIA PRIMA FACIE COMO MECANISMO ACELERATÓRIO DO JULGAMENTO DE DEMANDAS REPETITIVAS
}

Dissertação de Mestrado apresentada à Banca Examinadora da Faculdade de Direito da Universidade de São Paulo, como exigência parcial para a obtenção do título de Mestre em Direito Processual, sob orientação do Prof. Doutor Oreste Nestor de Souza Laspro.

FACULDADE DE DIREITO DA UNIVERSIDADE DE SÃO PAULO SÃO PAULO 2013 
BANCA EXAMINADORA 
Aos meus amados pais: do Céu e da Terra. 


\section{AGRADECIMENTOS}

Sempre pensei que agradecer fosse um gesto simples e fácil. Pelo menos é essa a ideia que sempre me venderam... está lá no dicionário - "agradecer: Mostrar-se grato por (benefício recebido)."

Contudo, cá estou eu há algum tempo pensando em como redigir essas aparentes simples linhas. Isto porque me dei conta que a gratidão envolve algo maior: o reconhecimento. O reconhecimento das benesses recebidas: e elas são muitas! São tantas que, às vezes, passam até de forma despercebida na correria quotidiana e este espaço é insuficiente para mencioná-las.

De plano, expresso meus sinceros agradecimentos ao meu estimado orientador Professor Doutor Oreste Nestor de Souza Laspro, pela confiança e estímulo na realização do presente trabalho.

A minha família amada (meus pais, irmãos, cunhados, sobrinhos), por compreenderem minha ausência e por todos os gestos e palavras de entusiasmo.

Aos meus queridos colegas de mestrado, em especial à Alessandra, Beatriz, Gabriela e Nathália, por atuarem pacientemente como ouvintes e incentivadoras.

Aos amigos da Justiça Federal, pelo inestimável apoio.

A todos os meus amigos, que participaram direta ou indiretamente desta empreitada, pelos momentos de descontração e pela torcida verdadeira.

Após uma extensa marcha de renúncias, abdicações, estudos, perseverança e muita fé em Deus, posso dizer a todos: concluímos mais uma etapa! Muito obrigada! 


\section{FRASE}

"As formas, solenidades, estruturas e categorias do direito processual não podem ser únicas, rígidas, inflexíveis ou absolutas. Prevalecem enquanto úteis ou necessárias à realização da justa composição do conflito de direito material. Quando essa meta exigir vias alternativas que melhor se adequem à tutela efetiva do direito subjetivo a resguardar ou restaurar, haverá de se franquear $o$ caminho procedimental que a tanto se afeiçoa. $O$ direito processual é dinâmico e não pode perder-se em conceitualismo e estruturalismo estáticos, incompatíveis com a função maior a desempenhar em prol da efetiva prestação de tutela ao direito e interesses materiais envolvidos em conflito". (Humberto Theodoro Júnior) 


\section{RESUMO}

O artigo 285-A do Código de Processo Civil foi introduzido em nosso ordenamento jurídico pela Lei $\mathrm{n}^{\mathrm{o}} 11.277 / 2006$, uma dentre outras tantas modificações advindas da denominada terceira fase da reforma do CPC, em clara tentativa de dar efetividade à garantia constitucional da razoável duração do processo. Para melhor compreensão da norma, o presente estudo faz uma breve incursão sobre a temática da morosidade processual, a relação entre o processo e os anseios da sociedade em relação à justiça, bem como acerca da necessária adequação dos institutos processuais ao mundo moderno, globalizado e informatizado. Investiga-se, ainda, a existência ou não de similares da norma em apreço em outros ordenamentos estrangeiros. O referido dispositivo permite ao magistrado o julgamento de plano, pela total improcedência, antes mesmo da citação do réu, de ações repetitivas, nos casos em que a matéria for unicamente de direito e já houver sido proferida sentença de improcedência em outros casos idênticos no mesmo juízo. Trata-se de evolução do ordenamento, surgindo como um novo momento processual para prolação de sentença de mérito, estabelecendo um procedimento todo peculiar para sua aplicação. No presente estudo, para além de temas como a polêmica existente em torno da inovação legislativa e os requisitos para sua incidência, surgem, ainda, o sistema recursal que a regra comporta, a possibilidade de aplicação do art. 285-A quando houver cumulação de pedidos, bem como sua aplicação nos processos de competência originária dos tribunais. Por fim, diante da existência de várias críticas ao dispositivo legal, bem como do pedido de declaração de sua inconstitucionalidade pelo Conselho Federal da Ordem dos Advogados do Brasil, por intermédio da Ação Direta de Inconstitucionalidade no 3.695/06, analisa-se a constitucionalidade do art. 285-A do CPC e sua consonância com os princípios processuais. Neste contexto, procura-se demonstrar que o julgamento prima facie de demandas repetitivas a que faz alusão o artigo 285-A não colide com a Constituição Federal, sendo, ao contrário, medida de efetivação da economia e celeridade processuais.

Palavras-chave: Art. 285-A, do CPC; julgamento prima facie de demandas repetitivas; requisitos de incidência; constitucionalidade. 


\begin{abstract}
Article 285-A of the Civil Procedure Code was introduced in our legal system by Law $\mathrm{n}^{\circ}$. 11.277/2006, one among many other changes arising from the so-called third phase of the $\mathrm{CPC}$ reforms, in an attempt to give effectiveness to the constitutional guarantee of reasonable duration of the procedure. For better understanding of the institute, this paper presents an overview about the matter of the procedural slowness, the relation between the process and the society expectations in respect to justice, as well as talks about the necessary adequacy of procedural institutes to the modern, globalized and computerized world. Also, it investigates if there are similar rules in other foreign legal system. The referred rule allows the prima facie judgment of dismissal for the judge, even before the defendant's citation, of repetitive actions where the matter is solely of law and has already been pronounced a merit sentence, denying the request, in other similar cases. It is the legal system evolution, emerging as a new procedural time for delivery of merit judgment, establishing a very specific application procedure. In this paper, besides issues like the controversy that exists around the legislative innovation, the requirement to its application, other questions emerge, such as: how is its appeal system, the applicability of art. 285-A when there is overlapping of demands, as well as in cases of original jurisdiction of the courts. Finally, given the existence of a lot of criticism to such article as well as the request for declaration of its unconstitutionality for the Federal Council of Brazilian Lawyers Association, through the Direct Action of Unconstitutionality $n^{0} 3.695 / 06$, it is analyzed the constitutionality of article 285-A of the CPC and its consonance with the procedural principles. In this context, it seeks to demonstrate that the prima facie judgment of repetitive demands referred in article 285-A does not conflict with the Federal Constitution and is, instead, a measure to bring economy and celerity to the process.
\end{abstract}

Key words: Article 285-A of the Code of Civil Procedure; prima facie judgment of repetitive actions; requirement to its application; constitutionality 


\section{SUMÁRIO}

INTRODUÇÃO.

\section{CAPÍTULO I. JULGAMENTO DE IMPROCEDÊNCIA PRIMA FACIE NA} CONJUNTURA DO PROCESSO CIVIL ATUAL

1.1. A crise da justiça e o problema da morosidade no julgamento dos processos: apreciação crítica

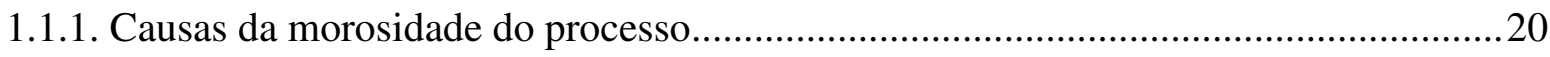

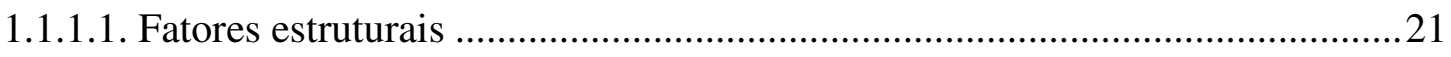

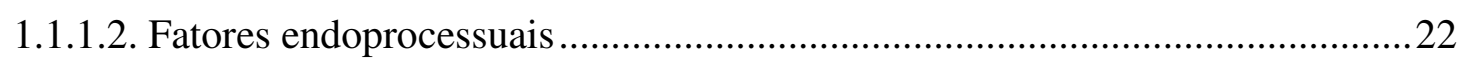

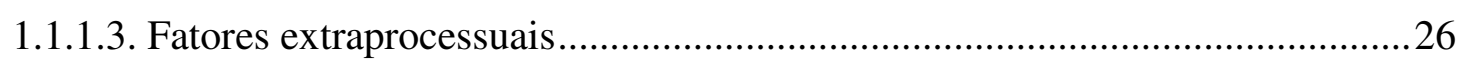

1.2. Litigiosidade excessiva e demandas repetitivas.............................................................29

1.3. As reformas do CPC e a busca pela celeridade processual..................................................32

1.4. Técnicas aceleratórias de julgamento de demandas repetitivas em grau recursal .................37

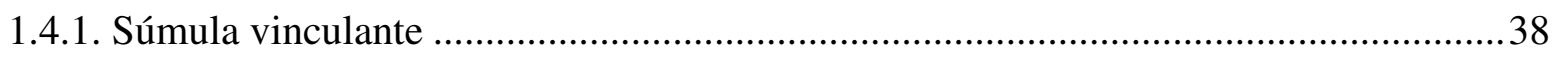

1.4.2. Análise da repercussão geral da questão constitucional, por amostragem ..................40

1.4.3. Julgamento do recurso especial por amostragem ...................................................46

1.5. Julgamento de improcedência prima facie do art. 285-A do Código de Processo Civil:

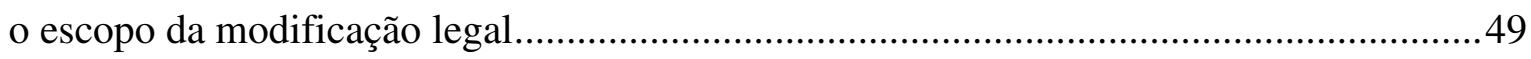

CAPÍtULO II. JULGAMENTO DE IMPROCEDÊNCIA PRIMA FACIE DE DEMANDAS REPETITIVAS: INTERPRETAÇÃO E ABRANGÊNCIA DO DISPOSTO NO ART. 285-A DO CPC ....................53

2.1. Sentença de improcedência prima facie do Art. 285-A do Código de Processo Civil: um novo momento para o julgamento de demandas repetitivas ........................................53

2.2. Institutos semelhantes ao Artigo 285-A do CPC ............................................................57

2.3. Julgamento de improcedência prima facie: um mecanismo "tupiniquim"? .........................65

2.4. Artigo 285-A do CPC: faculdade ou dever? .................................................................... 75

2.5. Requisitos para aplicação do Art. 285-A do CPC ................................................................ 77

2.5.1. Matéria controvertida unicamente de direito ....................................................... 78

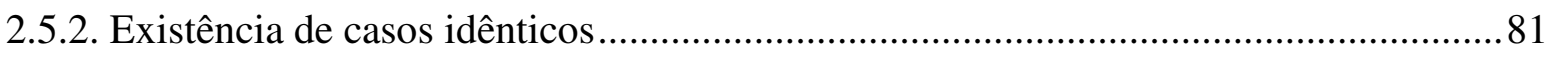

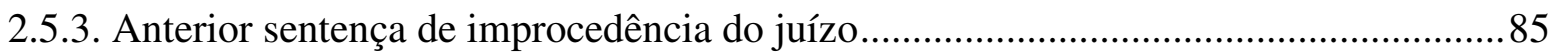

2.6. A utilização de súmula e/ou jurisprudência dominante do Supremo Tribunal Federal ou de Tribunal Superior como caso paradigma. 
2.6.1. Análise do cabimento da utilização de Súmula e/ou Jurisprudência dominante como caso paradigma pelo Juízo.

2.6.2. Confronto entre o entendimento do juiz de primeiro grau e súmula / jurisprudência do Supremo Tribunal Federal e Tribunal Superior

2.7. Sentença de improcedência de plano e demandas com pedidos cumulados: análise da possibilidade de cisão do julgamento.

2.8. Participação do MP (na qualidade de custos legis) e o Art. 285-A

2.9. Aplicação do Art. 285-A no âmbito dos tribunais, em termos de competência originária

2.9.1. Utilização do Art. 285-A no julgamento dos mandados de segurança de

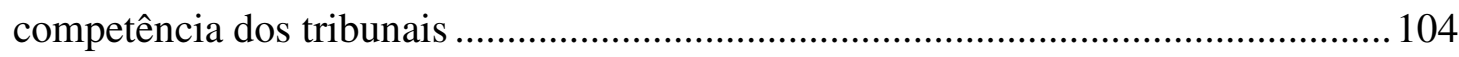

2.9.2. Utilização do Art. 285-A no julgamento de ação rescisória ..................................... 107

\section{CAPÍTULO III. QUESTÕES RECURSAIS ATINENTES À APLICABILIDADE DO} ART. 285-A DO CPC

3.1. Considerações iniciais

3.2. Do cabimento dos embargos de declaração

3.3. Do recurso adequado diante do julgamento de improcedência de plano e o princípio da fungibilidade recursal .

3.4. Objeto do recurso. 128

3.5. Juízo de admissibilidade do recurso de apelação.

3.5.1. Súmula de Jurisprudência dominante impeditiva de recurso: um novo requisito de admissibilidade recursal?

3.5.2. Compatibilidade com o artigo 557, caput, do CPC. 140

3.6. Juízo de retratação (Art. 285-A, $\S 1^{\circ}$, do CPC) 142

3.7. Citação 144

3.8. Natureza jurídica da resposta do réu 152

3.9. Julgamento da apelação pelo tribunal e a possibilidade de julgamento per saltum do mérito (Art. 515, $\S 3^{\circ}$, do CPC) 158

3.9.1. A reforma da decisão e o princípio da proibição da reformatio in pejus 163

3.10. Da formação da coisa julgada. 166

\section{CAPÍTULO IV. ANÁLISE DA CONSTITUCIONALIDADE DO ARTIGO 285-A DO CÓDIGO DE PROCESSO CIVIL}

4.1. Princípio da isonomia 


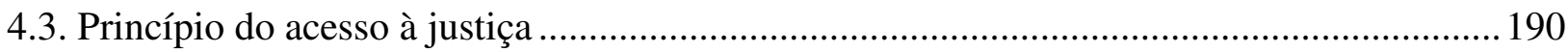

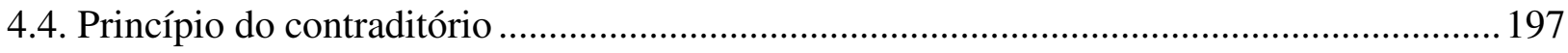

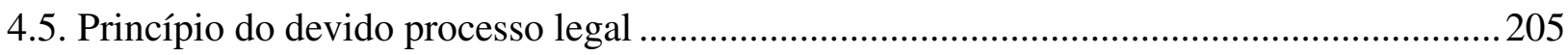

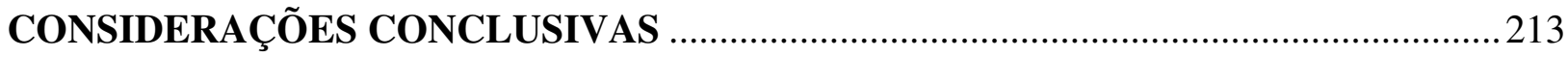

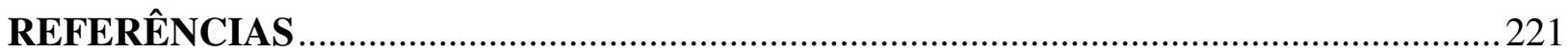




\section{INTRODUÇÃO}

Percebe-se que nas últimas reformas de direito processual civil tem buscado o legislador a inclusão de instrumentos que possam acelerar a tramitação dos processos em primeiro grau de jurisdição, bem como o julgamento dos processos nos tribunais. Mas qual seria a causa ou, ainda, as causas da morosidade processual? Trata-se de indagação que tem sido objeto de diversos estudos e acerca da qual o Capítulo 1 da presente dissertação se ocupará, já que divergentes são as respostas (os fatores determinantes apontados são os mais diversos possíveis, desde falta de estrutura e de recursos humanos, até deficiência do sistema processual) e complexas as soluções apontadas pela doutrina.

Com efeito, é notória a tentativa do legislador em adequar as leis às necessidades da sociedade. Ocorre que o Direito não tem obtido êxito em acompanhar a mutante realidade social, em especial nesse início de novo milênio, em que o surgimento de tecnologias da comunicação e informação alterou sobremaneira a forma de relações interpessoais em geral, de acesso à informação, a velocidade com que são realizados negócios jurídicos, bem como as ameaças e as lesões aos direitos acontecem, demandando retornos cada vez mais rápidos do Estado-Juiz, sob pena de tornar ineficaz a tutela prestada.

Foi com base nessas ideias, e tendo por motivação a sobrecarga de processos pendentes de julgamento, em especial aqueles que veiculam teses repetitivas e que tomam, de modo completamente irracional, tempo e dinheiro do Poder Judiciário, que foi atribuída aos magistrados a possibilidade de se utilizar do art. 285-A, do CPC, inserido no ordenamento pela Lei 11.277/2006.

O tema é polêmico, pois se permite ao juiz, em seu primeiro contato com a petição inicial, proferir, desde logo, julgamento de improcedência do pedido, sem citação do réu, abreviando, assim, o caminho do processo.

Têm-se a partir da Lei 11.277/2006 três ocasiões para que o magistrado profira julgamento de mérito, com fundamento no art. 269, inciso I, do CPC, quais sejam: (i) ainda na fase postulatória, ao despachar a petição inicial (art.285-A, do CPC, objeto de nosso estudo); (ii) na fase saneadora do processo, no denominado julgamento antecipado da lide (art. 330, do CPC); e (iii) na denominada fase decisória, finda a produção probatória. 
A partir da norma prevista no artigo 285-A do CPC buscar-se-á evidenciar e trazer à discussão, ao longo do Capítulo 2, alguns dos pressupostos que levam à aplicabilidade do instituto pelo julgador. Em primeiro lugar, é imprescindível observar que o artigo em comento não prima pela qualidade de redação. Da leitura do caput da norma surgem alguns questionamentos que, assim como outros estudiosos do tema, ansiamos por melhor esclarecer, quais sejam: o que vem a ser matéria controvertida unicamente de direito? Qual o significado da locução "casos idênticos"? Quis o dispositivo referir-se efetivamente a juízo ou a juiz? E, ainda, o que se entende por reprodução do teor da sentença anteriormente proferida?

Além disso, pretende-se verificar a possibilidade, em que pese a ausência de permissivo na norma, de se aplicar o art. 285-A nos casos em que, embora inexista orientação já assentada no grau de origem, houver súmula vinculante, súmula comum impeditiva, jurisprudência dominante nos tribunais superiores. Convém, ainda, examinar a possibilidade de julgamento de plano com base nos precedentes do juízo quando o entendimento dos tribunais caminhar em outro sentido.

O presente estudo tem por objeto, também, a análise da natureza do provimento judicial que contempla o julgamento de uma demanda com fundamento no artigo 285-A do CPC. Pretende-se, ainda, verificar a possibilidade de aplicação do dispositivo em testilha naqueles casos em que só se vislumbra sua aplicação no tocante à parcela dos pedidos da inicial. Nessa hipótese, a resposta da indagação acerca da natureza jurídica do provimento sofreria alteração?

Também no segundo Capítulo indaga-se, por oportuno, se o julgamento de improcedência de plano de processos repetitivos configura um mecanismo exclusivo de nosso ordenamento jurídico ou se encontra similares em sistemas estrangeiros, bem como se a possibilidade albergada pelo art. 285-A do CPC pode ser apontada como verdadeira novidade em nosso sistema. Além disso, cabe questionar se a medida configura faculdade ou dever do magistrado e se tem aplicação em demandas de competência originária dos Tribunais.

No capítulo seguinte, passa-se à difícil tarefa de sistematizar o tratamento legislativo recursal da disciplina, fazendo-se imperioso conectar diversos dispositivos esparsos e ordená-los de forma harmoniosa, de modo a colaborar com a coerência que a disciplina processual civil exige. 
Há de ser analisada a possibilidade de aplicação conjunta dos arts. 285-A, 515, § $3^{\circ}$ (julgamento per saltum), 518, $\S 1^{\circ}$ (súmula impeditiva de recurso) e 557 (poderes do relator) do Código de Processo Civil como forma de acelerar ainda mais o julgamento de processos.

Diante da simplicidade das orientações contidas nos parágrafos do dispositivo, verificar-se-á qual o recurso cabível diante do julgamento de improcedência de plano da demanda, bem como qual o seu conteúdo. Analisa-se, outrossim, alguns aspectos recursais concernentes à norma objeto do presente trabalho, tais como a realização do juízo de admissibilidade, o objetivo da citação do réu e suas possíveis atitudes, bem como as possíveis condutas do Tribunal diante do recurso. Além disso, será verificado se tal decisão é apta à formação de coisa julgada formal e material.

A questão da constitucionalidade do art. 285-A do CPC não é unânime e será objeto de análise do quarto capítulo, em que será apontada a divergência de entendimentos entre importantes doutrinadores pátrios. Ressalte-se, nesse particular, que a nova regra processual é questionada através da ADIn 3.695, ajuizada pelo Conselho Federal da Ordem dos Advogados do Brasil, por suposta incompatibilidade com os princípios do devido processo legal, contraditório, direito de ação, isonomia e segurança jurídica, motivo pelo qual merecem os mesmos uma análise mais detalhada.

Mostra-se pertinente o enfrentamento do tema, que se coloca como atual (fazendo parte, inclusive, do Projeto do Novo Código de Processo Civil) e envolve controvérsia a respeito de importante mecanismo a ser utilizado na busca da efetividade do processo. 


\section{CAPÍTULO I. JULGAMENTO DE IMPROCEDÊNCIA PRIMA FACIE NA CONJUNTURA DO PROCESSO CIVIL ATUAL}

\subsection{A crise da justiça e o problema da morosidade no julgamento dos processos: apreciação crítica}

Diante da ausência de um Estado forte o suficiente para frear o ímpeto individualista dos homens e fixar o direito acima da vontade dos particulares, a autotutela (ou autodefesa) foi, inicialmente, o mecanismo eleito para solucionar os conflitos. Da autotutela passou-se à autocomposição, em que o conflito é solucionado pelas partes envolvidas, sem ingerência de outros agentes.

Da solução parcial, ou seja, por ato das próprias partes houve a gradativa mudança para a busca de solução amigável e imparcial através de árbitros, pessoas de confiança mútua das partes. No direito romano arcaico, o fortalecimento do papel do Estado começou a reduzir a anterior indiscriminada esfera de liberdade dos indivíduos. A fim de evitar o subjetivismo e arbitrariedade do julgador evoluiu-se para a prévia estipulação de regras em abstrato, às quais as partes concordavam em se submeter e, num segundo momento, para a inauguração da justiça pública realizada, originariamente, por pretores, responsáveis por conhecer dos litígios e julgá-los. É o surgimento da atividade jurisdicional do Estado. ${ }^{1}$

A partir do instante em que o Estado avocou o monopólio da jurisdição, assumiu também a obrigação de garantir a todos os jurisdicionados a prestação de uma tutela adequada às suas necessidades. Daí porque a necessidade do Poder Judiciário ser acessível a todos, não podendo a lei excluir de sua apreciação lesão ou ameaça a direito.

O Estado, por intermédio da tutela jurisdicional, resguarda quem seja titular de um direito subjetivo. A função jurisdicional deve ser, inicialmente, entendida em contraposição às demais funções do Estado que abalizam o arcabouço constitucional, quais sejam: legislativa e executiva (art. $2^{\circ}$. da CF). Em outras palavras, é por intermédio desta jurisdição que o Estado utiliza-se do seu poder de decisão imperativa com escopo pacificador, o que o diferencia das demais funções do Estado, legislativa e administrativa.

${ }^{1}$ CINTRA, Antônio Carlos de Araújo; DINAMARCO, Cândido Rangel; GRINOVER, Ada Pellegrini. Teoria geral do processo. 26. ed. São Paulo: Malheiros Ed., 2010. p. 28-29. 
Atua o Estado, no exercício da jurisdição, como um terceiro que se sobrepõe àqueles que sentirão os reflexos da sua decisão, motivo pelo qual deve existir imparcialidade no exercício dessa atividade. A imparcialidade, que não se confunde com a neutralidade, é a ausência de interesse na causa com tratamento isonômico às partes, mantendo-se o Juiz equidistante.

Nos termos do artigo $2^{\circ}$ do Código de Processo Civil (CPC), há a necessidade de provocação da atividade jurisdicional, não atuando o Estado por iniciativa própria. Todavia, uma vez acionada a jurisdição caberá ao Poder Judiciário não somente declarar o direito, mas torná-lo efetivo, utilizando-se dos meios necessários à conversão da asserção ao plano social, daí a sua coatividade.

A relação jurídica processual é instrumento da relação de direito material e se inicia por meio da ação, que é um direito público autônomo, abstrato e condicionado. ${ }^{2}$ Trata-se do poder de ativar a máquina judiciária, retirando a jurisdição de sua inércia, exercida contra o Estado, para que esse tome providência e pacifique o conflito de interesses. ${ }^{3}$

O direito à prestação jurisdicional é essencial, pois dele depende a efetividade e proteção dos demais direitos. ${ }^{4}$ Cabe às partes a decisão de, após ponderação acerca da gravidade do conflito enfrentado, recorrer ou não ao Judiciário. Dessa forma, a função pacificadora do processo, instrumento da jurisdição, está ligada ao interesse das partes de levar ou não a sua pretensão até o Estado.

Existem, cabe salientar, outras formas de atuação - mesmo na esfera privada - que

\footnotetext{
${ }^{2}$ Ainda nesse sentido, adverte Sérgio Bermudes: "Reconhecer a natureza instrumental do processo não implica negar-lhe o valor; antes, significa compreender-lhe a exata utilidade, mas sem perder a perspectiva de que ele não se esgota em si mesmo, devendo, por isso, ser manejado por seus operadores com olhos postos na projeção dos seus efeitos na vida social”. (BERMUDES, Sério. Direito processual civil: estudos e pareceres: $2^{a}$ série. 2. ed. São Paulo: Saraiva, 1994. p. 98).

${ }^{3} \mathrm{~A}$ esse respeito, Antonio Carlos Marcato anota que: "vedada a realização da justiça pelo particular, ao Estado incumbe o poder-dever de prestá-la por meio de seu aparato judicial e com a observância do devido processo, embora sem perder de vista a sua finalidade instrumental: se a todos é assegurado incondicionalmente, o direito de reclamar a tutela estatal (correspondente ao direito de acesso à jurisdição), somente têm direito à tutela jurisdicional efetiva aqueles que estejam amparados ao plano do direito material. Mas essa efetividade não resulta exclusivamente da declaração da vontade concreta do direito - que é, afinal, apenas um dos fins do processo: analisado à luz de sua utilidade plena, processo efetivo é o capacitado ao cabal cumprimento de todos "os escopos do sistema, vistos em conjunto e compensadas certas deficiências por outras vantagens", tendo como idéia nuclear sua capacidade de exaurir os objetivos que o legitimam nos contextos jurídicos, social e político - daí, o "empenho em operacionalizar o sistema, buscando extrair dele todo o proveito que ele seja potencialmente apto a proporcionar, sem deixar resíduos de insatisfações por eliminar e sem se satisfazer com soluções que não sejam jurídica e socialmente legítimas". (MARCATO, Antonio Carlos. Crise da Justiça e influência dos precedentes judiciais no direito processual civil brasileiro. Tese (Professor Titular) - Faculdade de Direito, Universidade de São paulo, São Paulo, 2008. p. 10).

${ }^{4}$ Cf. CAPPELlETTI, Mauro; GARTH, Bryant. Acesso à justiça. Trad. de Ellen Gracie Northfleet. Porto Alegre: Fabris, 2002. p. 12-13.
} 
levam a resultados similares, tais como a arbitragem e a mediação. Desejável e imperioso, aliás, que se instiguem esses outros caminhos, reconhecendo-se que a atividade jurisdicional às vezes não é o instrumento mais apropriado para a aplicação do direito em determinadas situações, isto em virtude do grande volume de processos, formalismo, custo, especificidade do tema tratado, demora no julgamento, etc. ${ }^{5}$ Contudo, ainda hoje, a posição de supremacia e a imperatividade são prerrogativas atribuídas ao Poder Estatal.

É de se ressaltar, ainda, que uma vez provocada a atividade jurisdicional, o processo deve ser conduzido de maneira adequada, buscando-se a realização dos escopos social (educação para o exercício dos próprios direitos e respeito aos direitos alheios), político (preservação do valor liberdade, participação nos destinos do Estado e a preservação da autoridade do ordenamento jurídico) e jurídico (desempenho da vontade concreta do direito). ${ }^{6}$

A Constituição Federal de 1988 inseriu, no ordenamento jurídico pátrio, o princípio constitucional da inafastabilidade da jurisdição (art. 5 XXXV), garantindo, assim, a todos o acesso à justiça para proteção de direitos contra ameaça ou lesão.

Não é demais ressaltar que o simples acesso formal à justiça, idealizado à luz dos valores do Estado Liberal, não se alinha ao atual arquétipo constitucional brasileiro, previsto sob os valores do Estado Democrático de Direito, tendo por escopo a promoção da justiça social e a busca do bem comum.

Nesse diapasão, o acesso à justiça implica o acesso à ordem jurídica justa e pressupõe segundo ensinamento de Kazuo Watanabe: i) o direito à informação e completa noção do direito material; ii) o direito de acesso à justiça devidamente constituída e constituída por juízes inseridos na realidade social, assim como envolvidos com o objetivo de realização da ordem jurídica justa; iii) o direito à preordenação dos mecanismos

\footnotetext{
${ }^{5}$ Como bem pondera Carlos Alberto de Salles: "O modo judicial de solução de controvérsias deve ser visto como uma das formas dentro de um universo de alternativas parcial ou totalmente direcionadas aos mesmos fins. O reconhecimento dessa realidade permite melhor enquadrar a escolha e o momento de se recorrer a determinado mecanismo de solução de conflitos. Isso possibilita, em longo prazo, uma redução da sobrecarga do Judiciário, mas também tem a real importância de propiciar canais para uma resposta mais adequada à situação do interessado." (SALLES, Carlos Alberto de. Mecanismos alternativos de solução de controvérsias e acesso à justiça: a inafastabilidade da tutela jurisdicional recolocada. In: FUX, Luiz; NERY JR., Nelson; WAMBIER, Tereza Arruda Alvim (Coord.). Processo e Constituição: estudos em homenagem ao Professor José Carlos Barbosa Moreira. São Paulo: Ed. Revista dos Tribunais, 2006. p. 779-792, p. 784-785).

${ }^{6}$ CINTRA, Antônio Carlos de Araújo; DINAMARCO, Cândido Rangel; GRINOVER, Ada Pellegrini. Teoria geral do processo, cit., p. 30.
} 
processuais aptos a promover a efetiva tutela de direitos; iv) o direito à excisão de todos as barreiras que se anteponham ao acesso à justiça com tais características. ${ }^{7}$

A facilitação do ingresso no Judiciário, o desenvolvimento da sociedade brasileira, associado ao seu crescimento natural, fez acrescer de forma considerável o número de ações judiciais, o que não foi acompanhado da necessária atualização da sistemática processual, causando indevida morosidade no Poder Judiciário, ente detentor do monopólio da distribuição da justiça, o qual não estava apto a cumprir a contento seu papel. ${ }^{8}$

A busca pelo pleno acesso à tutela jurisdicional encontra sérios embaraços que necessitam ser removidos ${ }^{9}$, fatores que se apresentam em dimensões de variada complexidade, congregando aspectos de ordem política, econômica e social, tais como a insuficiência de informações imprescindíveis ao pleno exercício da cidadania devido ao baixo grau de escolaridade e de poder aquisitivo de parte da população e o alto custo das taxas judiciais. A falta de celeridade nos feitos e a demora na resolução dos processos judiciais também é fator de desestímulo àqueles que pensam em se socorrer do Poder Judiciário.

Para a melhor compreensão do presente trabalho, imprescindível se faz discorrer sobre o último obstáculo listado, o tempo. De fato, não é de hoje a discussão em torno do grave problema da lentidão do Poder Judiciário, atribuída, por muitos, ao intimidante volume de processos e de recursos que tramitam nos Juízos e Tribunais brasileiros, sobrecarregando-os.

\footnotetext{
${ }^{7}$ Cf. WATANABE, Kazuo. Acesso à justiça e sociedade moderna. In: DINAMARCO, Candido Rangel; GRINOVER, Ada Pellegrini; WATANABE, Kazuo. (Orgs.). Participação e processo. São Paulo: Ed. Revista dos Tribunais, 1988. p. 135.

${ }^{8}$ A respeito da crise do Judiciário, Ada Pellegrini Grinover asseverou: “A crise da Justiça está na ordem do dia: dissemina-se e serpenteia pelo corpo social, como insatisfação dos consumidores de Justiça, assumindo as vestes do descrédito nas instituições; atinge os operadores do direito e os próprios magistrados, como que impotentes perante a complexidade dos problemas que afligem o exercício da função jurisdicional; desdobra-se em greves e protestos de seus servidores; ricocheteia, enfim, pelas páginas da imprensa e ressoa pelos canais de comunicação de massa, assumindo dimensões alarmantes e estimulando a litigiosidade latente. A Justiça é inacessível, cara, complicada, lenta, inadequada. A Justiça é denegação de Justiça. A justiça é injusta. Não existe Justiça." (GRINOVER, Ada Pellegrini. A crise do Poder Judiciário. In: . O processo em evolução. 2. ed. Rio de Janeiro: Forense Universitária, 1998. p. 20-21).

${ }^{9}$ Como bem observa Ricardo de Barros Leonel, "para que todo o empenho de meios e pessoal na prestação jurisdicional não acabe figurando na realidade como um capricho inexeqüível, há necessariamente o estudioso do direito processual que percorrer, e o legislador que prover, caminhos pelos quais o provimento editado pelo Estado-juiz cumpra efetivamente sua finalidade." (LEONEL, Ricardo de Barros. Revisitando a teoria geral dos recursos: o efeito suspensivo. p. 2. Disponível em: <http://www.justitia.com.br/artigos/b9yc1y.pdf>. Acesso em: 27 nov. 2012).
} 
Tanto a morosidade no trâmite processual quanto a dificuldade de acesso ao Poder Judiciário acabam por lhe causar descrença e afetar sua legitimidade, haja vista que quanto menos resistente economicamente o jurisdicionado, mais se agravará a desigualdade substancial.

O problema da morosidade, contudo, não é exclusiva do direito brasileiro. ${ }^{10}$ Portugal é um exemplo de país em que o processo se desenvolve de forma lenta ${ }^{11}$, tanto é assim que a Constituição de Portugal, em seu art. 20, bem como o Código de Processo Civil Português, em seu art. 2-1 trazem dispositivos que procuram resguardar o direito ao julgamento em prazo razoável. Situação semelhante ocorre também na Itália. ${ }^{12}$

É de se salientar que o direito à duração razoável do processo e de meios que garantam a celeridade processual encontra guarita constitucional, sendo cogente criar condições para que tal direito seja respeitado. ${ }^{13}$ Em que pese o conceito de "razoável duração do processo" seja aberto, doutrina e a jurisprudência esmeram-se para definir qual prazo possa ser considerado aceitável para o recebimento da prestação jurisdicional.

A determinação do prazo deve ser verificada em cada caso concreto, como o estritamente necessário à solução do litígio com segurança. A mensuração da razoável duração do processo deve ter por critério a verificação de certas variáveis, tais como: a

\footnotetext{
${ }^{10}$ Confira-se reflexão de José Carlos Barbosa Moreira: "cabe prevenir contra a tendência, algo masoquística, a supor que a mazela da demora excessiva é peculiar à Justiça brasileira, ou que o Brasil, no particular, ocupa posição ainda pior do que a que lhe toca em matéria de distribuição de renda. O problema, na verdade, é universal e multisecular." (BARBOSA MOREIRA, José Carlos. A duração dos processos: alguns dados comparativos. Revista Síntese de Direito Civil e Processual Civil, v. 5, n. 29, p. 28-36, maio/jun. 2004).

11 "Em Portugal, de cuja experiência pretendo trazer aqui algum testemunho, os juízes eram, ainda há duas décadas, pessoas respeitadas e os tribunais tidos na conta de fazedores de justiça, em face dos cidadãos e em face da administração. Mas hoje, apesar de a eles se recorrer muito mais do que então, as sondagens revelam um descrédito profundo nos tribunais e nos juízes. Os processos demoram anos e os cidadãos deixaram de confiar." (FREITAS, José Manuel Lebre de. A exigência de celeridade e os princípios processuais (a experiência portuguesa). Revista da Faculdade de Direito do Sul de Minas (eletrônica), Pouso Alegrel v. 26 n. 2, p. 182, jul./ dez. 2010.

${ }^{12}$ Luciana Dias traz a baila dados estatísticos de processos italianos em andamento na Corte Europeia sendo que a maioria deles era referente à excessiva duração dos processos naquele país, o que pode ser apontado como um dos motivos que levou à elaboração de uma lei nacional que pudesse julgar estes dissídios - a lei 89/2001 que prevê o direito à reparação dos danos causados pela duração não razoável do processo no ordenamento italiano. (DIAS, Luciana Drimel. Dossiê Itália: a grave e profunda crise da duração dos processos/ alerta e subsídio. Revista de Direito Processual Civil Genesis, Curitiba, v. 7, n. 26, p. 780, out./dez. 2002). Importa ressaltar que o art. 111 da Constituição italiana, com a alteração sofrida no ano de 1999, passou a prever expressamente o direito à duração razoável do processo (ragionevole durata).

${ }^{13}$ Nesse sentido, destacamos que o Brasil é signatário do Pacto de São José da Costa Rica, o qual prevê em seu art. $8^{\circ}, 1$, que "Toda pessoa tem direito a ser ouvida, com as devidas garantias e dentro de um prazo razoável, por um juiz ou tribunal competente, independente e imparcial, estabelecido anteriormente por lei, na apuração de qualquer acusação penal formulada contra ela, ou para que se determinem seus direitos ou obrigações de natureza civil, trabalhista, fiscal ou de qualquer outra natureza”.
} 
dificuldade da matéria trazida a juízo, o local em que se desenvolve a causa, idade dos envolvidos, etc. ${ }^{14}$

Com efeito, diante da ausência de critérios objetivos ${ }^{15}$, não se deve dar ao tema um valor absoluto, estanque, devendo ser levado em conta a razoabilidade e as peculiaridades do caso submetido à apreciação jurisdicional. Não se deve furtar às partes o direito à ampla defesa, contraditório, oportunidade para produção de provas e interposição de eventuais recursos.

Os danos de uma justiça excessivamente morosa são diversos: causam indignação popular $^{16}$, desmoralizam a atuação do Poder Judiciário e, ainda, trazem sérios prejuízos à economia do país. ${ }^{17}$

Cabe ressalvar que a ciência processual contemporânea tem buscado elementos capazes de externar os valores segurança e celeridade ${ }^{18}$, a fim de dar uma resposta a essa

${ }^{14}$ Cf. DELGADO, José Augusto. Reforma do poder judiciário: art. 5º LXXVIII, da CF. In: WAMBIER, Teresa Arruda Alvim (Coord.). Reforma do Judiciário: primeiros ensaios críticos sobre a EC no 45/2004. São Paulo: Ed. Revista dos Tribunais, 2005. p. 363.

${ }^{15}$ Vladimir Passos de Freitas, ex-presidente do TRF-4, indagado em entrevista sobre o que venha a ser "prazo razoável”, assim se manifesta: "A Corte Européia de Direitos Humanos define três requisitos para determinar se o processo obedeceu ao prazo razoável: natureza da ação, protelação das partes e se o poder público estava à altura de oferecer o serviço pedido em tempo razoável, por exemplo, se tinha funcionário suficiente na vara, na secretaria e no cartório. Mas o fato é que ninguém sabe o que á prazo razoável. A Constituição de 67 dizia: O processo administrativo deverá terminar em 180 dias. Não sei se esse tempo é razoável, mas já é uma dica”. (FREITAS, Vladimir Passos de. [Entrevista concedida a Aline Pinheiro]. Revista Consultor Jurídico, 18 mar. 2007. Disponível em: <http://www.conjur.com.br/2007-mar18/nao_aposentadoria_doenca_judiciario?pagina=4>. Acesso em: 27 nov. 2012).

${ }^{16}$ A esse respeito, José Rogério Cruz e Tucci ilustra: "Todavia, além do alvitrado prejuízo de natureza material, que tem como fonte a decisão ou satisfação serôdia, presume-se, sempre, a amargura da parte interessada que padeceu, durante anos a fio, sofrendo também o inafastável mal de índole psicológica advindo da exacerbada duração do processo". (CRUZ E TUCCI, José Rogério. Tempo e processo: uma análise empírica das repercussões do tempo na fenomenologia processual (civil e penal). São Paulo: Ed. Revista dos Tribunais, 1997. p. 113).

${ }^{17}$ Com relação a este último item, trazemos oportuna lição de José Eduardo Faria: "É evidente que as crises de eficiência e identidade do Judiciário exercem um impacto negativo nas crises econômica e política de um país, do mesmo modo como também são por ela alimentadas. Há uma interação sistêmica entre todas essas crises, cujo resultado concreto tem sido a manutenção do círculo vicioso da pobreza, a distribuição desigual dos direitos adquiridos, a ampliação da concentração de renda, o agravamento das disparidades setoriais e regionais, o esgarçamento o tecido social, a expansão desordenada das normas dispositivas, programáticas e de organização, o aumento incessante de regras editadas por fatores meramente conjunturais, a expansão irracional das matérias submetidas a controle jurídico, a diluição das fronteiras entre o público e o privado, a emergência de um sem número de fontes materiais de um direito abrindo caminho para um efetivo pluralismo jurídico e a tendência ao esvaziamento das funções básicas do direito positivo”. (FARIA, José Eduardo. A crise do poder judiciário no Brasil. Justiça e Democracia, São Paulo, n. 1, p. 22, jan./jun. 1996).

${ }^{18}$ José Roberto dos Santos Bedaque leciona que "processo efetivo é aquele que, observado o equilíbrio entre os valores segurança e celeridade, proporciona às partes o resultado desejado pelo direito material." (BEDAQUE, José Roberto dos Santos. Efetividade do processo e técnica processual. 2. ed. São Paulo: Malheiros Ed., 2007. p. 49). 
insatisfação geral com a lentidão do sistema judicial brasileiro no julgamento das ações que lhe são postas a apreciação e que tanto sacrificam o direito material das partes.

Não é novidade que a prestação jurisdicional efetiva exige que o processo se dê em um lapso temporal razoável, devendo ser garantido os meios imprescindíveis ao seu alcance. ${ }^{19}$ Preocupado com a excessiva duração dos litígios judiciais e visando combater tal mal, o legislador pátrio promoveu no decorrer das últimas décadas uma série de reformas no sistema processual. A introdução do artigo 285-A no Código de Processo Civil consubstancia, como veremos ao longo do presente trabalho, tentativa de atribuir racionalidade e celeridade processual.

Convém, antes de darmos início ao estudo do tema central que nos propomos, analisarmos quais são os fatores apontados como responsáveis pela excessiva duração dos processos, dentre os quais se destacamos a litigiosidade de massa. Isto porque, só assim poderemos ponderar, ao final, se o art. 285-A do CPC pode ser apontado como instrumento hábil a cooperar com a tempestiva e efetiva entrega da prestação jurisdicional.

\subsubsection{Causas da morosidade do processo}

Na doutrina pátria, há muito se busca sistematizar, a fim de facilitar seu estudo e analisar suas consequências, as causas ensejadoras da morosidade dos processos judiciais.

José Rogério Cruz e Tucci, em primorosa obra, agrupou os fatores da lentidão em três classes, quais sejam: institucionais, derivados de ordem técnica e subjetiva e derivados da insuficiência material. ${ }^{20}$

No presente trabalho, optou-se por sistematização elaborada por Ricardo de Barros Leonel, que indica que os fatores ou motivos causadores da lentidão podem ser

\footnotetext{
${ }^{19} \mathrm{O}$ art. $5^{\circ}$, inciso LXXVIII, da Constituição Federal, incluído pela Emenda Constitucional $\mathrm{n}^{\mathrm{o}}$ 45, de 08.12.2004, consagrou o direito de todos "à razoável duração do processo", assegurado "os meios que garantam a celeridade de sua tramitação”. A menção a prazo razoável, contudo, já havia sido usada, na década de 50, pela Convenção Européia para Salvaguarda dos Direitos do Homem e das Liberdades fundamentais, em seu artigo $6^{\circ}, 1$ : "Toda pessoa tem direito a que sua causa seja examinada equitativa e publicamente num prazo razoável, por um tribunal independente e imparcial instituído por lei, que decidirá sobre seus direitos e obrigações civis ou sobre o fundamento de qualquer acusação em matéria penal contra ela dirigida”.

${ }^{20}$ A respeito do tema, e com pormenorizada verificação dos fatores atribuídos a cada uma dessas categorias, confira-se CRUZ E TUCCI, José Rogério. Tempo e processo: uma análise empírica das repercussões do tempo na fenomenologia processual (civil e penal), cit., p. 98-109.
} 
decompostos em 3 blocos (fatores endoprocessuais, extraprocessuais e estruturais) ${ }^{21}$, cuja análise será feita de forma detida a seguir.

\subsubsection{Fatores estruturais}

Os fatores estruturais que colaboram com a demora dos processos são aqueles relacionados à organização do Poder Judiciário, abrangendo a carência de pessoal (tanto de juízes como de servidores e auxiliares) e meios, bem como seu impróprio aproveitamento. $^{22}$

O número de magistrados e servidores na maior parte dos órgãos de primeira e segunda instância é muito aquém das necessidades, o que traz dificuldades para uma resposta célere e eficaz ao cidadão que busca o Poder Judiciário para ver solucionados seus conflitos. Percebe-se que o número de servidores e o provimento de cargos de juízes não se coadunam com o que seria necessário para dar maior mais agilidade ao andamento dos processos no Judiciário brasileiro.

Com o intuito de contribuir para a melhoria desse problema, a Emenda Constitucional $n^{\circ} 45 / 2004$ introduziu dispositivo que prevê que o número de juízes na unidade jurisdicional deve ser proporcional em relação à população e à demanda judicial da área (art.93, XIII, da CF). Trata-se, em nosso sentir, de dispositivo que expressa um ideal extremamente distante de ser obtido. Com efeito, segundo uma pesquisa conduzida pelo Instituto Paulista de Magistratura, sob coordenação do desembargador Caetano Lagrasta Neto e dos juízes Jayme Martins de Oliveira Neto e Durval Augusto Rezende Filho, a proporção entre juízes e desembargadores por habitantes no Brasil é uma das menores do mundo, especialmente na comparação com países europeus. A título de exemplo, enquanto na Alemanha, apontada como uma das justiças mais ágeis do mundo, existem 24 magistrados para 100.000 pessoas, no Brasil, são apenas 6 magistrados para o mesmo grupo populacional. ${ }^{23}$

\footnotetext{
${ }^{21}$ LEONEL, Ricardo de Barros. Revisitando a teoria geral dos recursos: o efeito suspensivo, cit., p. 5.

${ }^{22}$ LEONEL, Ricardo de Barros. Revisitando a teoria geral dos recursos: o efeito suspensivo, cit., p. 5.

${ }^{23}$ FALTA de juízes explica lentidão da Justiça, aponta pesquisa. Disponível em: $<$ http://veja.abril.com.br/noticia/brasil/falta-de-juizes-explica-lentidao-da-justica-aponta-pesquisa >. Acesso em 04 dez. 2012.
} 
Além da escassez de magistrados nos quadros do Judiciário, é de se apontar que como muitos juízes ingressam na magistratura ainda bem jovens, alguns deles não gozam de vasta experiência profissional prévia, o que pode causar, inicialmente, uma demora maior na análise dos casos e na formação de um entendimento.

A deficiência de servidores ${ }^{24}$ atuando pelas varas e cartórios do país é outro problema, sendo agravado pela falta de apropriada capacitação dos mesmos, fazendo-se imperioso o investimento em programas de qualificação que possam capacitá-los de forma adequada para enfrentar as questões que são postas à apreciação do sistema judicial.

Nesse sentido, não há como pensar em agilizar o trâmite das demandas sem que se verifique a necessidade de majoração dos quadros de juízes e de servidores, bem como o investimento em sua capacitação contínua.

Não se pode deixar de mencionar as péssimas condições de muitos edifícios onde estão instalados os fóruns e Tribunais, instalações físicas precárias, falta de material e equipamento e até mesmo as antiquadas organizações dos feitos por meio de fichários datilografados ou até manuscritos.

A tudo isso se contabilize a carência de equipamentos de informática, bem como falta de conhecimento técnico de manuseio por parte dos servidores, além da ausência de um sistema unificado de controle e gerenciamento de processos, que facilitaria o trâmite e dinamizaria a tramitação dos processos judiciais. ${ }^{25}$

\subsubsection{Fatores endoprocessuais}

Os fatores endoprocessuais referem-se às causas internas relacionadas à disciplina do processo. Dizem respeito, assim, à legislação e regras procedimentais processuais. ${ }^{26}$

Costuma-se atribuir exclusivamente à legislação a culpa pela morosidade. Em que pese tal afirmação não seja inteiramente verdadeira, fato é que, sem sombra de dúvidas, a esta cabe parcela da responsabilidade. Com efeito, é assente a presença no ordenamento

\footnotetext{
${ }^{24} \mathrm{E}$ aqui vislumbramos todos os auxiliares da Justiça, entendido "todas aquelas pessoas que de alguma forma participam da movimentação do processo, sob a autoridade do juiz, colaborando com este para tornar possivel a prestação jurisdicional”. (CINTRA, Antônio Carlos de Araújo; DINAMARCO, Cândido Rangel; GRINOVER, Ada Pellegrini. Teoria geral do processo, cit., p. 222).

${ }^{25}$ CRUZ E TUCCI, José Rogério. Tempo e processo: uma análise empírica das repercussões do tempo na fenomenologia processual (civil e penal), cit., p. 109.

${ }^{26}$ LEONEL, Ricardo de Barros. Revisitando a teoria geral dos recursos: o efeito suspensivo, cit., p. 5.
} 
processual brasileiro de normas e procedimentos extremamente formais, cuja complexidade, imperfeita apreensão de sua abrangência e inadequada aplicação têm contribuído de forma categórica para o fracasso do instrumento.

Observa-se a existência de normas processuais que demandam extremo rigor, dificultando que o processo atinja os seus fins de forma rápida, desvirtuando sua finalidade instrumental. Com efeito, esquece-se, muitas vezes, que o procedimento deve ser adequado à solução da natureza da questão colocada em debate. ${ }^{27}$

Necessário se faz simplificar o processo, isto é, racionalizar os atos e termos processuais a fim de que nele somente se incluam aqueles imprescindíveis à administração da justiça, deixando de lado aqueles considerados supérfluos e que sejam óbice ao seu regular andamento. ${ }^{28}$

Nesse sentido, convém lembrar que o artigo 154, do Código de Processo Civil, prevê que os atos processuais somente exigem forma determinada quando a lei expressamente assim o exigir. Logo, serão considerados válidos os atos que atinjam sua finalidade essencial, ainda que realizados de outra forma.

Vale ressalvar que nem todo formalismo é prejudicial ao processo, uma vez que há certas formalidades que devem mesmo ser observadas a fim de permitir melhor organização, eficiência e aproveitamento dos atos judiciais, além de assegurar igualdade e previsibilidade no desenvolver do processo. ${ }^{29} \mathrm{O}$ processo deve ser, assim, formal e não meramente formalista. ${ }^{30}$

\footnotetext{
${ }^{27}$ Nesse tocante, adotaremos a concepção de Kazuo Watanabe de que "é através do procedimento, em suma, que se faz a adoção das várias combinações de cognição considerada nos dois planos mencionados, criando-se por essa forma tipos diferenciados de processo que, consubstanciando um procedimento adequado, atendam às exigências das pretensões materiais quanto à sua natureza, à urgência da tutela, à definitividade da solução e a outros aspectos, além de atender às opções técnicas e políticas do legislador. Os limites para a concepção dessas várias formas são os estabelecidos pelo princípio da inafastabilidade do controle jurisdicional e pelos princípios que compõem a cláusula do "devido processo legal"". (WATANABE, Kazuo. Cognição no processo civil. 4. ed. São Paulo: Saraiva, 2012. p. 131).

${ }^{28}$ Confira-se, a esse respeito, lição de Paulo Eduardo Alves da Silva: "No sistema de justiça, a democracia se realiza pela ampla possibilidade de acesso dos cidadãos e pelas diversas oportunidades que os litigantes têm de apresentar suas alegações e debatê-las no processo. Isso é proporcionado por uma série de regras procedimentais, definidas em lei. Em geral, há uma presunção de que, quanto mais detalhadas essas regras, mais elevado o nível de igualdade entre as partes e mais democrático o processo. Mais isso nem sempre é verdadeiro. A profusão de regras pode sobrecarregar o procedimento e tornar demasiadamente longo e complexo o método dialético-investigativo de solução de conflitos. Nestes casos, a igualdade entre as partes e a democracia do acesso à justiça estariam ameaçadas, pois o litigante com melhores condições técnicas e financeiras está em posição de vantagem". (SILVA, Paulo Eduardo Alves da. Gerenciamento de processos. São Paulo: Saraiva, 2010. p. 30).

${ }^{29}$ GAJARDONI, Fernando da Fonseca. Flexibilização procedimental. São Paulo: Atlas, 2008. p. 133.

${ }^{30}$ Dessa ótica, defende BEDAQUE que "a forma na medida certa é fator de garantia. A ausência dela enseja abusos, normalmente por parte dos mais fortes. O formalismo exagerado, todavia, é sinônimo de burocracia, escudo utilizado pelos covardes e preguiçosos para esconder-se." (BEDAQUE, José Roberto dos Santos. Efetividade do processo e técnica processual, cit., p. 25).
} 
Aqui, vislumbra-se a exigência de atuação do Poder Legislativo para a eliminação de obstáculos processuais baldios e para criação de estruturas e procedimentos mais eficientes, que facilitem o acesso à Justiça.

Vivemos em uma sociedade extremamente dinâmica em que se desenvolvem diariamente relações de diversas ordens e isto muito se deve ao fenômeno da globalização e dos avanços tecnológicos. O direito e, de modo muito especial, o processo devem estar preparados para se adequar a essa nova realidade e fornecer instrumentos que atendam de forma satisfatória, célere e segura às novas demandas que lhe chegam.

Em nosso sentir, seria extremamente útil a adoção em nosso ordenamento jurídico de dispositivo semelhante àquele que consta do art. 265-A do Código de Processo Civil Português, com a redação dada pelo Decreto-Lei 180/1996, que instituiu o denominado "Princípio da Adequação Formal". ${ }^{31}$ Referido princípio tem por finalidade retirar qualquer entrave ao acesso à justiça, privilegiando a natureza instrumental do processo, caso a tramitação prevista em lei não se coadune com a finalidade do processo. ${ }^{32}$

Também não se pode deixar de mencionar queixa relacionada ao excessivo formalismo por parte dos magistrados na condução de demandas judiciais, transformando o processo num fim em si mesmo, desprestigiando o direito material. Usualmente se depara com decisões judiciais que se pautam por formalismos impertinentes, sem os quais haveria deslinde mais célere, dinâmico e justo às partes. Isso sem falar na utilização de linguagem extremamente rebuscada e truncada que dificultam o entendimento das partes e, algumas vezes, até mesmo de advogados. Deve-se primar pela informação clara e acessível dos julgados aos seus destinatários.

É bem verdade que os magistrados não são dotados de ampla margem de atuação, sendo que o sistema coloca ao seu alcance diversas opções procedimentais, competindo a eles optar, conjuntamente com as partes, a que melhor se coadune com o caso concreto. Com efeito, "é vedado às partes ou ao juiz se afastar do modelo legal, excepcionada a

\footnotetext{
${ }^{31}$ Referido artigo possui a seguinte redação: “Artigo $265 .^{\circ}-A$ - Princípio da adequação formal: Quando a tramitação processual prevista na lei não se adequar às especificidades da causa, deve o juiz oficiosamente, ouvidas as partes, determinar a prática dos actos que melhor se ajustem ao fim do processo, bem como as necessárias adaptações." E mais, consta da exposição de motivos do Decreto-lei no 329$\mathrm{A} / 95$, dentre outras, a intenção de "obviar-se a que regras rígidas de natureza estritamente procedimental possam impedir a efectivação em juízo dos direitos e a plena discussão acerca da matéria relevante para propiciar a justa composição do litígio".

${ }^{32}$ GAJARDONI, Fernando da Fonseca. Flexibilização procedimental, cit., p. 126.
} 
necessidade de variação com base na incapacidade das diversas opções tutelarem adequadamente e utilmente o caso concreto". 33

Entendemos que seria pertinente o incentivo à adoção pelos magistrados de técnicas de gerenciamento de processos (judicial case management), assim entendido como o planejamento da condução de demandas judiciais tendo por objetivo a mais adequada resolução dos conflitos com o menor dispêndio de tempo e recursos.

Esta seria possível por intermédio de um maior envolvimento e controle judicial na condução dos feitos, bem como da organização da unidade judiciária. Com efeito, o gerenciamento de processos tende a direcionar a atividade cognitiva do juiz às questões de fundo e menos às de forma e a incrementar qualitativamente a atividade das partes e seu relacionamento com o juiz. ${ }^{34}$

Pertinente, nesse aspecto, a participação dos processualistas para dirimir eventuais dúvidas procedimentais e buscar mecanismos aptos a simplificar o processo, suprimindo empecilhos que a técnica possa oferecer à efetividade da tutela jurisdicional. Em outras palavras, é preciso estar atento para dar o maior proveito às normas existentes compatibilizando, sempre que possível, com as novas relações que surgem na sociedade.

Convém destacar que está em discussão o Novo Código de Processo Civil - Projeto de Lei do Senado 166/10, em trâmite na Câmara sob o $n^{\circ} 8.046 / 10$, que prevê vários dispositivos cujo escopo é a simplificação e instrumentalidade processual. Nota-se o intento de afastar a processualidade exagerada e imprimir maior agilidade e simplicidade ao processo.

A título de exemplo propõe-se a diminuição das hipóteses de intervenção de terceiros, eliminando a oposição e a nomeação à autoria, sendo que esta última é posicionada no plano da correção da legitimidade (art. 328 do PLS 166/2010, na redação do substitutivo aprovado pelo Senado Federal em dezembro de 2010). Manteve-se o chamamento ao processo e a denunciação em garantia que corresponde à denunciação da lide (arts. 70 a 76 do CPC vigente), bem como a possibilidade de julgamento de improcedência liminar do pedido, conforme veremos ao longo do presente estudo.

\footnotetext{
${ }^{33}$ GAJARDONI, Fernando da Fonseca. Flexibilização procedimental, cit., p. 158.

${ }^{34}$ Em obra especialmente dedicada ao estudo do gerenciamento de processos judiciais, Paulo Edurado Alves da Silva sustenta que "O gerenciamento de processos não se reduz a um conjunto de técnicas determinadas em lei para aplicação pelo juiz, como no mais são as regras processuais. Não há um conjunto exaustivo de regras e procedimentos para a condução planejada de processos judiciais. Há, em verdade, uma racionalidade que os organismos judiciários incorporam para aplicar as regras processuais e realizar as atividades que lhe cabem." (SILVA, Paulo Eduardo Alves da. Gerenciamento de processos, cit., p. 30).
} 
Determinadas matérias que são hoje objeto de incidentes processuais específicos, como, por exemplo, a impugnação ao valor da causa (art. 261 do Código de Processo Civil), passam, na redação do Projeto, a ser arguidas por intermédio de requerimento dentro da contestação (art. 268 do PLS 166/2010). Também as exceções de suspeição e impedimento passam a ser alegadas mediante simples petição, acompanhada das respectivas provas documentais e/ou de rol de testemunhas.

Contudo, pecou-se ao rejeitar proposta de flexibilização mais altiva, nos termos originariamente pressagiados no PLS 166/2010, que assegurava ao magistrado, por um dispositivo genérico, poderes amplos de adaptação do procedimento às peculiaridades do caso, em dicção análoga àquela constante do art. 265-A do Código de Processo Civil Português. Prevê o artigo 118, do novo CPC, os poderes dos juízes, sendo que seu inciso V faz alusão à possibilidade de o magistrado “dilatar os prazos processuais e alterar a ordem de produção dos meios de prova, adequando-os às necessidades do conflito, de modo a conferir maior efetividade à tutela do bem jurídico”.

\subsubsection{Fatores extraprocessuais}

Os fatores extraprocessuais dizem respeito aos aspectos relacionados ao desenvolvimento da demanda em juízo, porém que lhe são externos. Tratam-se de causas de ordem social e cultural, como é o caso, por exemplo, da exagerada litigiosidade, a crise na advocacia ou problema da cultura legal local. ${ }^{35}$

Como bem identificou Cândido Rangel Dinamarco, atualmente reconhece-se a existência de peculiar conexão entre o sistema processual e as relações sociais, sendo a litigiosidade contida considerada fator de infelicidade e desagregação, daí ter o Estado como papel primordial a pacificação e eliminação de conflitos. ${ }^{36}$

De fato, observou-se nos últimos anos, até como consequência às ondas renovatórias de acesso à justiça, uma maior conscientização da sociedade acerca de seus direitos, bem como incremento da busca da resolução dos conflitos fundamentada na

\footnotetext{
${ }^{35}$ LEONEL, Ricardo de Barros. Revisitando a teoria geral dos recursos: o efeito suspensivo, cit., p. 5.

${ }^{36}$ DINAMARCO, Cândido Rangel. A reforma do Código de Processo Civil. São Paulo: Malheiros Ed., 2001. p. 127.
} 
jurisdição estatal e no processo. ${ }^{37}$ Ocorre que o incremento da litigância não foi acompanhado de forma satisfatória por oferta de serviços pelo Poder Judiciário. ${ }^{38}$

A simplificação do acesso à justiça foi e deve permanecer como um norte a ser sempre perseguido na aplicação da lei e na reforma estrutural do Judiciário. Deve-se, contudo, distinguir o acesso à justiça que consiste na facilitação de ingresso em juízo às partes, bem como mecanismos que permitam sua efetiva participação na formação do convencimento do magistrado, da litigiosidade exacerbada, que deve ser combatida.

Em outras palavras, o acesso à justiça, isto é, a aproximação do jurisdicionado ao Poder Judicial com a finalidade de receber de forma efetiva seus direitos é uma grande conquista, sendo extremamente válido. Nesse sentido, diversos mecanismos, entre eles a criação dos Juizados Especiais, são responsáveis por permitir que indivíduos, antes não representados, agora tenham pleno acesso à prestação jurisdicional oficial. A problemática, contudo, surge com a ampliação da judicialização extrema dos conflitos, o que se dá pela conjugação de múltiplas causas de origens diversas.

A esse respeito, o professor Rodolfo de Camargo Mancuso, anota, com exatidão, que a garantia constitucional da inafastabilidade do Judiciário tem recebido, no Brasil, leitura irrealista que o coloca, de forma equivocada, como atividade primária e universal do Estado, sendo que "todo e qualquer interesse contrariado ou insatisfatório deve, de pronto, ser submetido a um órgão judicial". Essa compreensão, acrescenta o autor, leva a exageros, disseminando a, por ele chamada, “cultura demandista”, que leva a crer que a judicialização dos conflitos é o caminho natural para toda sorte de interesses contrariados ou insatisfeitos, desestimulando a busca pela solução alternativa dos conflitos e criando uma falsa expectativa quanto à eficácia da prestação jurisdicional. ${ }^{39}$

\footnotetext{
${ }^{37}$ A corroborar o que se está a dizer, temos que entre os anos de 1990 e 2000 houve um vertiginoso aumento no número de processos, que passaram de cerca de 3,6 milhões para o patamar de 20 milhões de ações. (CONSELHO NACIONAL DE JUSTIÇA. Demandas repetitivas e a morosidade na justiça cível brasileira. Disponível em: <http://www.cnj.jus.br/images/pesquisasjudiciarias/Publicacoes/pesq_sintese_morosidade_dpj.pdf>. Acesso em 29 nov. 2012).

${ }^{38}$ Conforme enfatiza Carlos Simões: "É indiscutivel que um dos acontecimentos mais marcantes da última década foi o considerável crescimento da massa litigiosa devido ao aumento populacional, aos conflitos sociais, à ampliação do rol dos direitos, à melhoria dos mecanismos para a defesa desses direitos, ao reconhecimento dos interesses coletivos e dos legitimados a defendê-las, bem como à conscientizacão da população quanto aos direitos a que faz jus, fenômenos que, reunidos, ocasionaram a multiplicação dos litígios e contribuíram para o "esgotamento" do sistema judicial para solucioná-los adequadamente." (FONSECA, Carlos Simões. Sincretismo processual e acesso à justiça. São Paulo: LTr, 2009. p. 47).

${ }^{39}$ MANCUSO, Rodolfo de Camargo. Acesso à justiça: condicionantes legítimas e ilegítimas. São Paulo: Ed. Revista dos Tribunais, 2011. p. 462-463.
} 
Embora exista o denominado descrédito às instituições jurídicas, interessante ressaltar que o número de processos só tem aumentado no Judiciário. O que pode ser comemorado por um lado, isto em virtude de uma maior conscientização da sociedade acerca de seus direitos, decorrente de obtenção de maior número de informações através dos meios de comunicação e certa conscientização política, por outro lado, traz carga negativa à celeridade processual. ${ }^{40}$

O aumento da litigiosidade e a preferência pela resolução dos conflitos mediante a atuação de um terceiro (Estado), titular do poder coercitivo, tem sido objeto de estudos por sociólogos do direito, juristas e até mesmo economistas. Costuma-se apontar como razões para tais fatos a democratização do Estado, como o aumento do rol de direitos e garantias fundamentais, bem como fatores históricos, como o desenvolvimento econômico e social do último século. ${ }^{41}$

É de se ressaltar, ainda, a postura de muitos advogados que, talvez até por desconhecimento ou falta de domínio de outras técnicas como a mediação e conciliação, acabam por optar fazer uso somente de soluções contenciosas e adjudicadas dos conflitos, onerando sobremaneira o sistema. ${ }^{42}$

Fato é que, independentemente de suas causas, a propagada litigiosidade contida ou reprimida parece estar ganhando vazão e inundando o Poder Judiciário com inúmeras demandas, algumas desnecessárias, ocasionando, por ausência de planejamento prévio, sobrecarga no sistema judiciário.

\footnotetext{
${ }^{40}$ Nessa seara, oportuno transcrever trecho de entrevista concedida por Maria Tereza Sadek a Aline Pinheiro e veiculada no sítio eletrônico Consultor Jurídico. Em referida oportunidade, indagada se o Poder Judiciário cumpre seu papel de fazer Justiça, respondeu: "Não há serviço público com tamanha procura como o Judiciário. São milhões de ações. Ao mesmo tempo, a população diz que a Justiça não funciona, que só serve para os ricos. Como pode acontecer essa situação? É um paradoxo. As pessoas não acreditam no Judiciário, mas o movimento é surpreendente. Então, a qual dos lados eu dou crédito? Eu acredito nos dois lados. Para entender, é preciso fazer um diagnóstico correto de quem recorre à Justiça, porque recorre, qual a natureza do pedido. É aí que falta informação". (SADEK, Maria Tereza. Entrevista concedida por Maria Tereza Sadek a Aline Pinheiro. Consultor Jurídico. Disponível em: $<$ http://www.conjur.com.br/2006-jan-08/justica_trabalha_nao_chega_cidadao>. Acesso em: 28 nov. 2012).

${ }^{41}$ Pesquisa veiculada pelo sítio eletrônico do Conselho Nacional da Justiça aponta que, "para além do cidadão, que crescentemente tem se tornado mais consciente dos seus direitos, existem no Brasil vários canais de incentivo à judicialização dos conflitos, tais como: o próprio setor público, a advocacia e a mídia”. (CONSELHO NACIONAL DE JUSTIÇA. Demandas repetitivas e a morosidade na justiça cível brasileira, cit.) - grifos do original.

${ }^{42}$ DUARTE, Ricardo Quass. O tempo inimigo no processo civil brasileiro. São Paulo: LTr, 2009. p. 71.
} 


\subsection{Litigiosidade excessiva e demandas repetitivas}

No contexto acima mencionado, temos um enorme número de processos repetitivos, versando acerca das mesmas questões de direito, que ocupam elevado tempo do juiz e espaço físico nos armários e prateleiras. Este número, é bom salientar, está longe de diminuir, muito pelo contrário, haja vista o continuado desenvolvimento socioeconômico brasileiro.

Convém destacar que o Código de Processo Civil foi extremamente influenciado pelo liberalismo, sendo o processo estruturado para veicular demandas individuais. Todavia, com o passar dos anos, tal sistema revelou-se inadequado para tutelar as novas relações sociais que envolvem direitos difusos, coletivos e individuais homogêneos, o que ensejou a edição de normas processuais voltadas à tutela coletiva como é o caso do Código de Defesa do Consumidor, da lei da ação popular e da ação civil pública.

Mesmo diante da edição de referidas normas, porém, perdura a multiplicação de repetitivas demandas individuais que veiculam casos judiciais massificados a respeito de um mesmo bem jurídico, resultado das atividades tanto do setor público quanto da iniciativa privada.

Observa-se, assim, que a excessiva litigância não ocorre apenas por parte daqueles que se encontravam às margens da atuação Estatal e sim também por parte de alguns órgãos públicos e privados, que parecem se aproveitar do problema da morosidade para postergar ao máximo a solução dos conflitos.

Essas demandas repetitivas, que refletem casos em que a situação jurídica dos interessados é no todo semelhante, fez reacender discussão acerca dos diferentes tipos de pessoas que litigam em juízo: os chamados litigantes eventuais e os litigantes habituais, bem como acerca da vantagem que estes levam sobre os primeiros.

Os litigantes eventuais são aqueles que se socorrem do Judiciário de forma esporádica, ocasional, enquanto que os litigantes habituais acessam os órgãos judiciais de forma frequente, possuindo vasta experiência judicial. São estes os denominados por Marc Galanter “one-shotters" e “repeat-players”. Afirma-se haver elevado grau de sobreposição dos litigantes habituais em face dos litigantes eventuais em virtude dos seguintes fatores: $(i)$ maior experiência com o direito, o que possibilita melhor estruturação e planejamento da situação, (ii) a economia de escala, por ter mais casos, (iii) a 
possibilidade de manter relações contínuas com os membros da instância decisória, (iv) a possibilidade de diluição dos riscos da demanda por maior número de casos e $(v)$ tolerância para jogar com probabilidades e testar estratégias com determinados casos, de modo a desenvolver expectativas de precedentes mais favoráveis em casos futuros. ${ }^{43}$

Outro acontecimento que se seguiu e, ao lado da influência da tecnologia, corroborou para o aumento dos processos repetitivos, diz respeito ao surgimento de novo mercado entre os grandes escritórios de advocacia: o contencioso de massa. ${ }^{44}$

Com efeito, diversos escritórios atentos a essa nova "fatia" de mercado, criaram equipes de advogados e estagiários todos voltados ao mesmo cliente, os quais, com o auxílio do computador e da internet, são responsáveis por milhares de ações tratando sobre pouquíssimas controvérsias: juros abusivos em cartão de crédito, cobranças indevidas na conta telefônica, etc. Tal praxe possibilita reproduzir petições e recursos com extraordinária facilidade, bem como gerenciar, por meio de modernos sistemas de acompanhamento processual um enorme número de processos.

Deve-se buscar uma alteração na mentalidade dos jurisdicionados no sentido de que somente o Judiciário estaria autorizado a resolver os conflitos existentes, para que se possa verificar a oferta da prestação jurisdicional oficial como mecanismo subsidiário, a ser acionado nos casos em que efetivamente é necessário. ${ }^{45}$ Contudo, enquanto não há alteração dessa mentalidade, deve ser preocupação do legislador e dos operadores do direito buscar mecanismos para não frustrar as pretensões do número cada vez maior de pessoas que apelam ao Estado para ver seus direitos declarados e realizados.

Assim, não se pretende afastar a legitimação do Poder Judiciário perante a sociedade civil, desencorajando as pessoas a buscarem reparação pelo manejo do processo,

\footnotetext{
${ }^{43}$ GALANTER, Marc. Afterword: explaining litigation. Law and Society Review, v. 9, p. 360, 1975). Disponível em: <http://marcgalanter.net/Documents/afterwardexplaininglitigation.pdf>. Acesso em: 04 dez. 2012.

${ }^{44}$ A esse respeito, confira-se: “A advocacia, na busca de novos nichos de atuação que favoreçam o ingresso de novos clientes, fomenta a reprodução da litigiosidade por meio da criação de novas teses jurídicas. Observa-se o fenômeno da expansão da advocacia massiva contenciosa (especificamente no âmbito previdenciário, um único escritório pode ser responsável por $25 \%$ dos processos de uma vara). Grandes escritórios conseguem oferecer formas de cobrança mais atraentes, muitas vezes vinculadas ao êxito da demanda. Havendo concessão da gratuidade processual, o ajuizamento representa ao cliente somente possível ganho, não implicando qualquer ônus com despesas processuais. Nessa advocacia de massa é notório constatar deficiências frequentes na postulação técnica (petição inicial e documentação) e na própria condução do processo que acarretam a necessidade de atos processuais adicionais e tornam o trâmite judicial mais demorado." (CONSELHO NACIONAL DE JUSTIÇA. Demandas repetitivas e a morosidade na justiça cível brasileira, cit.) - grifos do original.

${ }^{45}$ MANCUSO, Rodolfo de Camargo. Acesso à justiça: condicionantes legítimas e ilegítimas, cit., p. 462-463.
} 
mas sim buscar mecanismos de dar celeridade ao processo e imprimir maior velocidade na sua condução, tornando efetiva a tutela prestada.

Na mesma linha, José Marcelo Menezes Vigliar defende que ao invés de apontar o aumento de litigiosidade como um dos fatores do emperramento do sistema judicial brasileiro, deve-se buscar o seu contigenciamento, isto é, imposição de limites que não provoquem a restrição dos direitos dos jurisdicionados, mas que impliquem no incremento da possibilidade de julgamento conjunto de matérias semelhantes. Por meio de tal conduta, sustenta o autor, "não só o volume experimentará redução, mas a possibilidade de compreensão uniforme do ordenamento jurídico se verificará." 46

As demandas repetitivas devem receber tratamento peculiar, sendo necessária a adoção de mecanismos aptos a lhes dar solução num curto espaço de tempo, a fim de que não sejam utilizadas com intuitos protelatórios. Além da celeridade deve-se buscar, sempre que possível, instrumentos de uniformização de jurisprudência.

Referidas demandas fazem parte da realidade atual, sendo forçoso voltar os olhos dos estudiosos e dos operadores do direito para sua análise e compreensão, bem como estudar mecanismos que permitam lhes dar o tratamento diferenciado que merecem, haja vista as suas particularidades.

É bom frisar que o processamento de causas semelhantes (e não idênticas, como teremos oportunidade de mostrar), por si só, não desafia, sobremaneira a capacidade da estrutura judicial, nem tampouco os princípios jurídicos (como os da isonomia, do contraditório, da segurança jurídica), enquanto elas estiverem diluídas em pequeno volume nos órgãos judiciais. Com efeito, a problemática não emerge da semelhança entre as demandas, mas sim da sua repetição em ampla quantidade, que faz acrescer o trabalho, bem como o consumo do tempo e dinheiro do Poder Judiciário.

Sem dúvida, um grande desafio para o tratamento da questão está na estrutura e na motivação das equipes. No que diz respeito à infraestrutura, há carência de espaços adequados para armazenar o enorme volume de processos. Por sua vez, no que se refere à gestão de pessoas, a atividade desempenhada pelos servidores no mais das vezes é repetitiva e pouco intelectual, o que exige estímulo constante.

\footnotetext{
${ }^{46}$ VIGLIAR, José Marcelo Menezes. Litigiosidade contida (e o contigenciamento da litigiosidade). In: SALLES, Carlos Alberto de (Coord.). As grandes transformações do processo civil brasileiro: homenagem ao professor Kazuo Watanabe. São Paulo: Quartier Latin, 2009. p. 58-59.
} 
Com efeito, não é nada incomum que, para fazer frente à grande avalanche de processos que chegam ao Judiciário, os juízes elaborem decisões e sentenças a serem reproduzidas nos feitos por seus assessores, sob sua supervisão, os quais fazem apenas as adaptações necessárias ao caso analisado.

Feita essa análise da diversidade de fatores que levam à excessiva litigiosidade no Judiciário, em especial de demandas repetitivas, bem como dos atores envolvidos e tendo em vista que tais demandas parecem não ter recebido o adequado tratamento por um longo período, o que levou à elevação do tempo de duração dos processos, convém verificar as soluções que foram apontadas, especificamente no campo legislativo processual, a fim de melhor equacionar tal problemática.

Como veremos a seguir, diversos foram os mecanismos introduzidos pelas reformas processuais visando tutelar de forma diferenciada os processos repetitivos ${ }^{47}$, dentre eles: a súmula vinculante do Supremo Tribunal Federal; o sistema de processamento e julgamento por amostragem dos recursos especiais repetitivos, a repercussão geral do recurso extraordinário e, mais recentemente, a possibilidade de o juiz de primeiro grau julgar a causa improcedente (portanto, análise de mérito), antes mesmo da citação do réu, em casos expressamente previstos.

Como se percebe, inicialmente, os mecanismos foram criados para serem utilizados em fase mais avançada do processo, isto é, em fase recursal. Esta última técnica, assim, se sobressai ao servir de filtro, logo na fase inicial do processo, às demandas repetitivas descabidas, merecendo um melhor estudo de suas peculiaridades.

\subsection{As reformas do CPC e a busca pela celeridade processual}

O atual Código de Processo Civil brasileiro entrou em vigor no dia $1^{\circ}$ de janeiro de 1974, e além de manter diversos institutos e aprimorar outros já existentes no CPC de

\footnotetext{
${ }^{47}$ Observa-se a escolha do legislador de, ao invés de encaminhar essas macrolides à jurisdição coletiva como defende Rodolfo de Camargo Mancuso, pactuar com o manejo de repetitivas demandas judiciais, para somente depois agrupá-las e dar-lhe manejo massivo. (MANCUSO, Rodolfo de Camargo. Acesso à justiça: condicionantes legítimas e ilegítimas, cit., p. 477-478). A justificativa para tal conduta, a nosso ver, pode estar no fato de que tais demandas repetitivas se incluem em categoria "cuja homogeneidade não é suficientemente intensa a justificar o tratamento coletivo da controvérsia e nem há razoável dispersão dos interessados a tornar a tutela coletiva mais eficiente, a despeito de empiricamente repetitivos os pedidos." (RODRIGUES, Viviane Siqueira. O processo coletivo para a defesa dos direitos individuais homogêneos. 2012. Dissertação (Mestrado)_ Faculdade de Direito, Universidade de São Paulo, São Paulo, 2012. p. 155).
} 
1939, inspirou-se em diplomas similares da Itália, Alemanha e Portugal, conforme se verifica da exposição de motivos.

Questão sobre a qual tem se debruçado os estudiosos do Direito Processual na atualidade diz respeito a como equacionar efetividade da prestação jurisdicional e acesso à justiça, de modo a proporcionar ao cidadão uma resposta mais rápida do Poder Judiciário.

De acordo com Mauro Cappelletti e Bryant Garth o acesso à justiça “não é apenas um direito social fundamental, crescentemente reconhecido; ele é, também, necessariamente, o ponto central da moderna processualística. Seu estudo pressupõe um alargamento e aprofundamento dos objetivos e métodos da moderna ciência jurídica”. 48

Assim, constata-se ser de rigor um processo efetivo e tempestivo, sob pena de garantir ao jurisdicionado uma eficácia aparente e tornar um processo injusto.

Foram realizados vários movimentos na comunidade jurídica para atingir este escopo, o que se verifica através da grande quantidade de reformas que foram realizadas desde a instituição do Código de Processo Civil de 1973.

O movimento por acesso à justiça analisa e procura os caminhos para superar os obstáculos que tornam inacessível para tantas pessoas a aquisição da prestação jurisdicional apropriada. São apontados três óbices que afrontam o pleno acesso à justiça, quais sejam: a deficiência econômica, parcos conhecimentos dos direitos pelos cidadãos e o excessivo apego ao individualismo. ${ }^{49}$

Ao longo de pouco mais de 35 anos de vigência, o CPC atual sofreu o efeito de mais de 60 leis dentre pequenas alterações e minirreformas. As alterações no corpo do Código foram iniciadas no próprio ano de 1973, com a edição da Lei $\mathrm{n}^{\circ} 5.925$, que modificou vários de seus dispositivos.

No final do ano de 1994 sobrevém a primeira grande onda reformista do Código de Processo Civil que proporcionou diversas inovações, dentre elas podemos citar a nova sistematização da tutela antecipada, da tutela específica das obrigações de fazer e não fazer, o novo regime do recurso de agravo, entre outras.

Fechando esse primeiro ciclo, podemos apontar a Lei $n^{\circ} 8.953 / 1994$ que alterou topicamente o processo de execução e a edição da Lei $n^{\circ}$ 9.079/1995, que introduziu no nosso sistema processual a ação monitória.

\footnotetext{
${ }^{48}$ CAPPELLETTI, Mauro; GARTH, Bryant. Acesso à justiça, cit., p 12-13.

${ }^{49}$ CAPPELLETTI, Mauro; GARTH, Bryant. Acesso à justiça, cit., p 15-29.
} 
Embora de grande contribuição, as alterações ainda pareciam insuficientes. Em 2001 e 2002, concretizou-se a segunda grande reforma do Código de Processo Civil, que teve como assuntos mais proeminentes: limitação dos casos de reexame necessário, a fungibilidade entre as providências antecipatórias e as medidas cautelares incidentais, reforço da execução provisória, permissão de conversão de agravo de instrumento em agravo retido pelos relatores, limitação dos casos de cabimento de embargos infringentes, etc. São exemplos de leis editadas em tal período a Lei 10.358/01, que alterou o processo de conhecimento no que diz respeito aos deveres dos sujeitos processuais, à apresentação do rol de testemunhas pelas partes e ao acompanhamento da produção da prova pericial pelas partes, bem como a Lei 10.444/02, que tratou de diversos institutos, como a determinação do valor de alçada para a adequação da causa ao procedimento sumário, a audiência preliminar, a execução para a entrega de coisa certa, entre outros.

Apesar do caráter revolucionário desta fase reformista, uma espécie de continuação das práticas introduzidas pela reforma anterior, visando dar maior efetividade à prestação jurisdicional, não logrou êxito a mesma em trazer eficiência de fato, uma vez que o trâmite processual se tornou ainda mais demorado com o aumento do número de demandas.

A Emenda Constitucional $\mathrm{n}^{\mathrm{o}} 45$, de 08 de dezembro de 2004, a qual se convencionou chamar de Emenda Constitucional da Reforma do Poder Judiciário, trouxe outras importantes inovações constitucionais, capazes de contribuir, sem dúvida, para a prestação de uma justiça em tempo razoável, tais como a garantia da duração razoável do processo, a federalização das violações aos direitos humanos, a súmula vinculante, a repercussão geral da questão constitucional como pressuposto para a admissibilidade do recurso extraordinário e os Conselhos Nacionais da Magistratura e do Ministério Público.

$\mathrm{Na}$ forma de anexo ao texto da Reforma, os representantes do Executivo, Legislativo e Judiciário firmaram um pacto de Estado "em favor de um Judiciário mais rápido e republicano". Este Pacto proporcionou um novo pacote de reformas ao CPC, o que denotou, de maneira bem clara, que as modificações até então empreendidas não haviam sido suficientes para a efetiva melhora da qualidade da prestação jurisdicional.

A terceira onda de reforma iniciou-se nos anos de 2005 e 2006, originando outras alterações, dentre as quais destacamos: a Lei 11.187/05, que alterou novamente o regime do agravo, a Lei n ${ }^{\circ} 11.232 / 05$, que trata do novo procedimento de execução e liquidação de sentença; a 11.276/2006, que instituiu a súmula impeditiva de recurso, bem como a Lei 
11.277/2006, que cuida da sentença de improcedência prima facie, objeto de análise do presente trabalho.

Não é demais mencionar também a Lei 11.280/2006, que diz respeito à incompetência relativa, meios eletrônicos, prescrição, distribuição por dependência, exceção de incompetência, revelia, carta precatória e rogatória, ação rescisória e vista dos autos, Lei 11.417/06, que regulamentou a edição da súmula vinculante no STF; Lei 11.418/06, que regulamentou a repercussão geral no STF; Lei 11.419/06, que dispõe sobre os meios eletrônicos processuais; Lei 11.441/07, que possibilitou que o inventário e a partilha, a separação e o divórcio fossem feitos extrajudicialmente; Lei 11.672/08, que introduziu o artigo 543-C, e parágrafos, no CPC, versando sobre o julgamento dos recursos repetitivos, fundados na mesma questão de direito, entre outras.

Depreende-se, pelo exame do conciso resumo das leis acima mencionadas, que esta terceira fase almejou diminuir o trâmite processual, isto é, ensejar uma maior celeridade processual, consubstanciada no princípio da razoável duração do processo, por meio da diminuição do número de processos a serem julgados.

Um número tão grande de alterações em nosso diploma processual não saiu ileso a críticas. Paulo Roberto de Gouvêa Medina compartilha seu receio no seguinte sentido "o que preocupa, nessa última etapa da reforma do CPC, é o afã de imprimir celeridade ao processo a qualquer preço. É preciso não confundir, com efeito, justiça rápida com justiça apressada". ${ }^{0}$

Em abril de 2009, os representantes dos três poderes se reuniram para a assinatura do II Pacto Republicano de Estado por um Sistema de Justiça mais acessível, ágil e efetivo. O documento procura dar continuidade àquele assinado em 2004 e tem por objetivos o incremento do acesso universal à Justiça, especialmente dos mais necessitados, o aprimoramento da prestação jurisdicional, sobretudo em relação à duração dos processos, e o combate à violência e criminalidade, por meio de políticas de segurança pública combinadas com ações sociais e proteção à dignidade da pessoa humana. A intenção é racionalizar o processo e o julgamento dos conflitos de massa.

Contudo, as novidades não param por aqui. Isto porque, sob o argumento de dar mais celeridade ao Poder Judiciário, o Senado Federal encarregou uma Comissão de

\footnotetext{
${ }^{50}$ MEDINA, Paulo Roberto Gôuvea. As Reformas do CPC. Disponível em: <http://www.oab.org.br/oabEd./users/revista/1205506460174218181901.pdf>. Acesso em 15 nov. 2010.
} 
Juristas, presidida pelo Ministro Luiz Fux, a elaboração do Anteprojeto do Novo Código de Processo Civil. Com a apresentação do anteprojeto ao Senado Federal, deu-se início ao Processo Legislativo através do Projeto de Lei do Senado $n^{\circ} .166 / 2010$, em trâmite na comissão especial da Câmara sob o n ${ }^{\circ}$ 8.046/10. Depois, a matéria seguirá ao plenário da Câmara, antes de ser devolvido ao Senado em razão das diversas alterações que o texto deve sofrer.

As mudanças no novo código têm como objetivo diminuir a morosidade da Justiça brasileira, afastando o excesso de formalidades e reduzindo as possibilidades de recursos, trazendo racionalidade para o julgamento de demandas pelo Poder Judiciário.

Entre os destaques do texto do projeto de novo Código de Processo Civil está a criação de um mecanismo de resolução de demandas repetitivas. O mecanismo aplicaria uma só decisão proferida pelas instâncias superiores, após fixação de tese, a todas as ações que tratem de um mesmo tema, desde que presentes dois requisitos: controvérsia com potencial de gerar relevante multiplicação de processos fundados em idêntica questão de direito e o temor da insegurança jurídica em virtude de decisões conflitantes a respeito do mesmo tema. Desse modo, inúmeros processos seriam finalizados de semelhante maneira e num curto espaço de tempo, desafogando o Judiciário. ${ }^{51}$ É de se ressaltar também o prestígio de meios eletrônicos, limitação ao número de testemunhas, aumento da multa para recursos protelatórios, entre outros.

Em que pese o projeto de novo Código de Processo Civil não tenha saído incólume a críticas $^{52}$, quer nos parecer que o mesmo apresenta inovações de grande relevo, que permitem uma maior simplicidade e coesão no ordenamento. ${ }^{53} \mathrm{O}$ ministro Teori Zavascki,

\footnotetext{
${ }^{51}$ A respeito do tema, Leonardo Carneiro da Cunha sustenta que ao invés da utilização da técnica de forma preventiva, como prevê o dispositivo, "seria mais adequado prever o incidente quando já houvesse algumas sentenças antagônicas a respeito do assunto". (CUNHA, Leonardo Carneiro da. Anotações sobre o incidente de resolução de demandas repetitivas previsto no Projeto de Novo Código de Processo Civil. Revista de Processo, São Paulo, v. 36, n. 193, p. 258, mar. 2011).

${ }^{52}$ Por todos, confira-se censura do professor Antonio Cláudio da Costa Machado acerca do relatório do Deputado Sérgio Barradas (PT-BA) apresentado à Câmara: "De todo o exposto e tendo em vista como se encontra projetado o Código de Processo Civil mais autoritário de que já se teve notícia em nossa história, fica também a certeza de que o prevalecimento do relatório Sérgio Barradas poderá representar uma grande porta aberta à incontrolabilidade das decisões, insegurança jurídica e à própria corrupção no seio do Poder Judiciário". (MACHADO, Antonio Cláudio da Costa. Relatório sobre novo CPC na Câmara é autoritário. Consultor Jurídico, 29 ago. 2012. Disponível em: <http://www.conjur.com.br/2012-ago-29/costa-machadorelatorio-cpc-camara-autoritario >. Acesso em: $01 \mathrm{dez}$. 2012).

${ }^{53}$ Fredie Didier Júnior que inicialmente mostrou-se desfavorável à necessidade de um novo CPC reviu seu entendimento e fez questão de veiculá-lo publicamente: "Fiz questão de escrever este pequeno editorial, como forma de apresentar publicamente o meu confiteor. É que, em 2008, defendi publicamente a desnecessidade de um novo CPC. Um ano de discussão do assunto na Câmara, tendo ouvido quase duas centenas de pessoas sobre o assunto, me fez mudar de opinião. Cumpro o meu dever de dar este
} 
após reunião com deputados relatores do projeto do novo CPC (PL 8.046/2010) e outros ministros do STJ alertou, contudo, para a necessidade de maiores reflexões no tocante às ações coletivas, bem como no que diz respeito a instrumentos judiciais que tornem dispensável repetir várias vezes o mesmo julgamento. Conforme enfatiza o ministro, "o projeto atende em parte a essa necessidade de redução dos litígios, mas nós podemos avançar mais. Tivemos hoje aqui várias ideias nesse sentido, de prestar mais autoridade às decisões já tomadas e inibir o aparecimento de novas ações". ${ }^{4}$

Questiona-se a necessidade de elaboração de um novo Código, bem como se não seriam suficientes apenas algumas alterações pontuais. É compreensível que a substituição de um diploma complexo como é um código processual, depois de anos de vigência, gere incertezas e encontre resistências. Contudo, não há como se negar que o Código atual sofreu inúmeras alterações ao longo do tempo, perdendo, de certa forma, coesão. Vê-se, assim, ser válida a proposta, que não configura, ao que tudo indica, ruptura com o sistema atual, mas sim sua evolução, com o aperfeiçoamento de muitas das técnicas já existentes. Daí a importância da participação dos diversos segmentos da sociedade no que diz respeito às propostas de modificações o que, ao menos aparentemente, tem sido oportunizado.

\subsection{Técnicas aceleratórias de julgamento de demandas repetitivas em grau recursal}

A estrutura tradicional do processo civil não foi idealizada para diferenciar e tratar adequadamente os milhares de ações repetitivas, o que fez com que estas fossem, em regra, processadas pelo mesmo tipo de procedimento empregado às demandas convencionais.

As recentes reformas do Código de Processo Civil, porém, trouxeram diversos institutos novos destinados, ainda que não de forma específica, ao manejo desse contingente litigioso, com o escopo de adotar caminhos mais curtos e menos dispendiosos para a Justiça. Ressaltamos, desde já, que foge do escopo deste trabalho analisar de forma aprofundada tais mecanismos. O objetivo deste tópico é tão só demonstrar que,

esclarecimento público, reafirmando o postulado da minha atividade intelectual: o jogo da ciência não tem fim; quem não se predispõe a rever suas ideias deve sair da brincadeira”. (DIDIER JÚNIOR, Fredie. Razões para um novo CPC. Confiteor. Fredie Didier. Disponível em: $<$ http://www.jurisciencia.com/noticias/razoes-para-um-novo-cpc-confiteor-fredie-didier/1523/>. Acesso em: 01 dez. 2012.

${ }^{54}$ MINISTROS do STJ destacam pontos críticos do novo CPC. Migalhas. Disponível em: $<$ http://www.migalhas.com.br/Quentes/17,MI162264,101048-

Ministros+do+STJ+destacam+pontos+criticos+do+novo+CPC>. Acesso em: 01 dez. 2012. 
originariamente, as reformas trouxeram um conjunto de normas tendo por objeto a contenção da litigiosidade nos Tribunais.

Apenas num segundo momento é que se percebeu a necessidade e, acima de tudo, a utilidade da criação de um mecanismo, um verdadeiro filtro, que pudesse desde logo combater o crescente número de demandas repetitivas, bem como diminuir o tempo de litigância, do que é exemplo o art. 285-A do CPC, permitindo ao juiz proferir julgamento de improcedência prima facie de ações repetitivas. Trata-se, assim, de evolução da tendência de adaptação da tutela jurisdicional às demandas repetitivas e opção política pela racionalização dos trabalhos do Judiciário. O objetivo deste estudo é, justamente, esmiuçar essa técnica, no intuito de verificar os requisitos exigidos em lei bem como elucidar as polêmicas decorrentes de sua aplicação.

\subsubsection{Súmula vinculante}

O ordenamento jurídico prevê a existência de dois tipos de súmulas: as vinculantes e as não vinculantes, sendo que somente se admite a coexistência dessas duas espécies no STF. A súmula vinculante aproxima-se dos precedentes vinculativos dos países do Commom Law, e tem por objetivo precípuo superar controvérsia atual sobre a validade, a interpretação e a eficácia de normas capazes de gerar insegurança jurídica e relevante propagação de processos. Tem, portanto, o condão de vincular diretamente os órgãos judiciais e os órgãos da Administração Pública, abrindo a possibilidade de que qualquer interessado faça valer a orientação do STF.

Nos termos do art. 103-A da Constituição Federal a Súmula Vinculante deverá ser aprovada por maioria de $2 / 3$ dos votos do STF, havendo de incidir sobre matéria constitucional que tenha sido objeto de decisões reiteradas no Tribunal. As súmulas não vinculantes, por sua vez, são aquelas firmadas pela nossa Suprema Corte sem observância dos requisitos constitucionais. ${ }^{55}$

\footnotetext{
55 "Para que o STF possa editar verbete com força vinculante, nos termos da CF 103-A e do LSV $2^{\circ}$, devem estar preenchidos os seguintes requisitos: a) a tese jurídica que se quer afirmar em verbete de Súmula vinculante tem de dizer respeito a norma constitucional; b) o objeto do verbete tem de ser a validade, a interpretação ou a eficácia de norma constitucional; c) controvérsia atual entre os órgãos do Poder Judiciário ou entre eles e a administração pública sobre a validade, a interpretação ou a eficácia de norma constitucional questionada; d) grava insegurança: a controvérsia atual deve ter aptidão para gerar grave insegurança jurídica; e) relevante multiplicação de processos sobre questão idêntica acarretada
} 
A aprovação, bem como a revisão e o cancelamento de súmula, poderá ser provocada pelos legitimados para a propositura da ação direta de inconstitucionalidade, sem prejuízo do que vier a ser estabelecido em lei. A possibilidade de revisão ou cancelamento de Súmula é de extrema relevância, tendo em vista que é de natureza da própria sociedade e do direito estar em constante transformação, daí a necessidade de flexibilidade no sistema sumular. ${ }^{56}$

Contra o ato administrativo ou decisão judicial que contrariar a súmula aplicável ou que indevidamente a aplicar, caberá reclamação ao STF. O Supremo Tribunal Federal, julgando-a procedente, anulará o ato administrativo ou cassará a decisão judicial reclamada, e determinará que outro seja proferido com ou sem a aplicação da súmula, conforme o caso. ${ }^{57}$

Ressalte-se que a adoção de súmulas vinculantes diminui o ativismo nos órgãos de jurisdição ordinária e funciona como mecanismo de uniformização das decisões, afastando decisões contraditórias e contribuindo para abrandar movimentos de recalcitrância que são prejudiciais ao tratamento isonômico.

Luiz Guilherme Marinoni vai além e defende a extensão do efeito vinculante também às súmulas do Superior Tribunal de Justiça sob o fundamento de que caberia tanto ao STF quanto ao STJ a resolução das questões jurídicas, cabendo aos juízes e tribunais de $2^{\circ}$ grau a análise fática, apontando a melhor forma do deslinde do feito. Ressalta o autor, ainda, que erram aqueles que alegam que os juízes podem decidir de forma distinta dos tribunais superiores, uma vez que tal conduta colabora tão somente com o aumento de recursos. $^{58}$

Convém salientar que o art. 285-A do CPC não faz menção à possibilidade de julgamento de improcedência de plano com fundamento em súmula, seja ela vinculante ou não, motivo pelo qual perdura a indagação acerca de qual deve ser conduta do juízo de $1^{\circ}$

pela controvérsia a respeito da norma constitucional questionada; f) reiteração das decisões do STF no mesmo sentido da afirmação da tese jurídica objeto do verbete vinculante; g) quórum qualificado: decisão por 2/3 dos membros do STF (oito ministros) afirmando a tese do verbete vinculante; h) publicação do verbete vinculante na imprensa oficial (DOU elou DJU)". (NERY JÚNIOR, Nelson; NERY, Rosa Maria Andrade. Código de Processo Civil comentado e legislação processual civil extravagante em vigor. 11. ed. São Paulo: Ed. Revista dos Tribunais, 2010. p. 796).

${ }^{56}$ MENDES, Gilmar Ferreira; COELHO, Inocêncio Mártires; BRANCO, Paulo Gustavo Bonet. Curso de direito constitucional. 2. ed. rev. e atual. São Paulo: Saraiva, 2008. p. 967.

${ }^{57}$ PELEJA JÚNIOR, Antônio Veloso. Reformas do Código de Processo Civil e novos mecanismos de acesso à justiça. Curitiba: Juruá, 2010. p. 278-279.

${ }^{58}$ MARINONI, Luiz Guilherme. Ações repetitivas e julgamento liminar. Revista Jurídica, Porto Alegre, v. 55, n. 354, p. 55-56, abr. 2007. 
grau em tais casos. Nos casos em que há súmula vinculante, parece-nos que não há como fugir à sua aplicação, havendo verdadeira obrigação do magistrado de decidir no mesmo sentido que a súmula vinculante do STF, uma vez que a ofensa à súmula vinculante dá ensejo à propositura de reclamação constitucional.

\subsubsection{Análise da repercussão geral da questão constitucional, por amostragem}

O Supremo Tribunal Federal, instituído para ser a Corte Constitucional brasileira, há muito estava em crise. Isto porque estava na contingência de analisar todas as questões dirigidas ao Poder Judiciário, o que acarretou o abarrotamento de processos no Tribunal e, por conseguinte, morosidade em suas decisões.

Nesse sentido, Carlos Alberto Carmona argumenta que o problema vem de longa data, desde a origem do recurso extraordinário, tendo em vista sua conformação amplíssima, que possibilitava um sem-número de causas. Ressalta, ainda, que o Supremo foi tratado como mais uma instância, ou seja, de Guardião da Constituição, tornou-se mera terceira instância. ${ }^{59}$

Para delimitar a função do Supremo, foi promulgada a Emenda Constitucional $\mathrm{n}^{\circ}$. 45/2004, que através da introdução do $\S 3^{\circ}$ no art. 102 da Constituição Federal inseriu o instituto da repercussão geral da questão constitucional ${ }^{60}$. A regulamentação da citada alteração deu-se pela Lei 11.418 de 2006 que introduziu para tanto os artigos 543-A e 543B ao Código de Processo Civil.

A Emenda Regimental ao Regimento Interno do Supremo Tribunal Federal (RISTF) $\mathrm{n}^{\mathrm{o}}$ 21, de 30.04.2007, trouxe as modificações necessárias para que a regulamentação da repercussão geral fosse concluída.

O que o texto preceitua no entendimento de Arruda Alvim é que, para que possa a vir ser conhecido e julgado o recurso extraordinário, é necessário que a repercussão da matéria discutida seja geral, isto é, “(...) que diga respeito a um grande espectro de pessoas ou a um largo segmento social, uma decisão sobre assunto constitucional

\footnotetext{
${ }^{59}$ CARMONA, Carlos Alberto. Recurso extraordinário: uma análise do acesso do Supremo Tribunal Federal. São Paulo: Atlas, 2007.

${ }^{60}$ Dispõe o Art. 102, § $3^{\circ}, \mathrm{CF}$ - "No recurso extraordinário o recorrente deverá demonstrar a repercussão geral das questões constitucionais discutidas no caso, nos termos da lei, a fim de que o Tribunal examine a admissão do recurso, somente podendo recusá-lo pela manifestação de dois terços de seus membros”.
} 
impactante, sobre tema constitucional muito controvertido." Corroboramos o entendimento do professor Arruda Alvim quando o insigne processualista afirma que " $a$ expressão 'repercussão geral' significa praticamente a colocação de um filtro ou de um divisor de águas em relação ao cabimento do recurso extraordinário (...)". ${ }^{61}$

A repercussão geral ocorre quando há interesse coletivo pelo desfecho da causa, ou seja, interesse público e não somente dos envolvidos naquele litígio. Desde a edição da EC/45 que trouxe a expressão repercussão geral havia dúvida quanto ao seu real significado, já que se tratava de um conceito vago.

Pretende o $\S 1 \circ$ do art. 543-A do CPC conceituar o que vem a ser a repercussão geral. Considera-se presente tal requisito quando a questão discutida apresente relevância do ponto de vista econômico, político, social ou jurídico, que ultrapassem os interesses subjetivos da causa.

A despeito de ainda veicular um conceito muito amplo e subjetivo, tal norma regulamentadora indica que apenas temas de notável importância, com transcendente relevância é que merecerão a atenção da Corte Suprema brasileira. Não há dúvida, entretanto, que pela extensa margem de subjetivismo inerente a esse novo requisito, incumbirá, em última análise, aos ministros do STF, construir, cotidianamente, o conceito de repercussão geral. Em que pese seja algo extremamente complexo definir o que seja de relevância em determinado período de tempo, foi opção do legislador deixar a cargo do órgão julgador tal tarefa.

No tocante à natureza jurídica da repercussão geral, temos tratar-se de requisito de admissibilidade recursal, em virtude de figurar expressamente no $\S 3^{\circ}$, do art. 102, da Constituição Federal, que o recorrente deverá demonstrar a repercussão geral das questões constitucionais debatidas no caso, a fim de que o Tribunal examine a admissão do recurso. $^{62}$

O $\S 3 \circ$ do mesmo artigo 543-A veicula, por sua vez, norma bastante interessante, pois cria uma situação em que há presunção iure et de iure da presença da repercussão geral. Dispõe o dispositivo em comento que há presunção de que as matérias sumuladas

\footnotetext{
${ }^{61}$ ALVIM, Arruda. A EC. N. 45 e o Instituto da Repercussão Geral. WAMBIER, Tereza Arruda Alvim et al. (Coord.) Reforma do Judiciário: primeiras reflexões sobre a Emenda Constitucional n. 45/2004. São Paulo: Ed. Revista dos Tribunais. 2005. p. 63-64.

${ }^{62}$ Contudo, entendemos importante mencionar o entendimento de Arruda Alvim que defende que a repercussão geral não afeta a admissibilidade ou o mérito do recurso. Trata-se, para ele, de ato de avaliação política, prévio à possibilidade de admissão. Não sendo ato de julgamento, a decisão não teria caráter jurisdicional. (ALVIM, Arruda. A EC. N. 45 e o Instituto da Repercussão Geral, cit., p. 64).
} 
pelo STF ou que foram objeto de reiteradas decisões são, por só esse motivo, dotadas de repercussão geral.

No tocante ao procedimento, traz o $§ 2 \circ$ do art. 543-A duas situações que merecem destaque, quais sejam: a) a repercussão geral é matéria a ser analisada exclusivamente pelo STF, sendo, pois, defeso ao juízo a quo adentrar na apreciação desse requisito específico; b) o requisito da repercussão geral é antecedente e prejudicial a qualquer outro, de modo que incumbe ao recorrrente, antes de discutir qualquer matéria, analiticamente demonstrar a existência dessa transcendência da causa. Vale ressaltar que se trata de regra de regularidade formal e uma vez não observada pode acarretar o não conhecimento do RE.

Indo adiante, pela redação do $\S 44^{\circ}$, que trata da competência e do quorum para a deliberação acerca da presença ou não da repercussão geral, cabe ao Plenário do STF a verificação de sua presença. Entretanto, quando, na Turma, que é composta de cinco ministros, quatro deles decida pela presença da repercussão geral, a remessa ao Plenário é dispensada. Fácil entender, no caso, o motivo da desnecessidade do envio a Plenário. O artigo $102, \S 3^{\circ}$, da $\mathrm{CF} / 88$, ao prever o requisito em comento, veicula regra que exige o voto de dois terços dos membros do plenário para deixar de conhecer um recurso por ausência de repercussão geral, o que equivale a oito votos em onze. Assim, se na Turma quatro ministros já concluíram pela presença da repercussão geral, o máximo que se obteria no plenário seriam sete votos pela ausência desse requisito, o que seria inferior aos $2 / 3$ exigidos pela norma constitucional.

Com relação ao juízo de admissibilidade do recurso extraordinário há certa polêmica. Parcela da doutrina defende que é vedado ao juízo a quo analisar a presença da repercussão geral, sendo que tal tema seria de apreciação exclusiva pelo STF.

Nesse sentido, Rodrigo Barioni explica que, frente ao art. $102, \S 3^{\circ}$ da CF, o recurso extraordinário não poderá sofrer juízo de admissibilidade pelo Tribunal local por duas razões:

Primeiro, porque se é certo que compete ao presidente do órgão a quo examinar a admissibilidade do recurso extraordinário, é igualmente induvidoso que esse juízo de admissibilidade faz-se por meio de decisão unipessoal do presidente. Como o texto constitucional prevê que a recusa, pela falta de 'repercussão geral', somente poderá ser tomada por dois terços dos membros do tribunal, a apreciação da 'repercussão geral' deve ser feita por órgão colegiado, o que já é suficiente para impedir o exame desse tema pelo presidente do tribunal a quo. 
A esse argumento, alinha-se outro: a localização da norma. $\mathrm{O}$ art. 102, caput, da CF trata da competência originária e recursal do STF. A inclusão do $\S 3^{\circ}$ no art. 102 indica seu indissociável vinculo com o caput. A partir daí, tem-se que o vocábulo 'tribunal' significa STF, de forma que incumbe a este e não ao tribunal a quo apreciar a alegação de repercussão geral da matéria constitucional. ${ }^{63}$

Entende de modo diverso Sérgio Bermudes ${ }^{64}$, para quem o primeiro juízo de admissibilidade, tal qual ocorre com todos os recursos interpostos, será feito pelo Tribunal local. Assim, seria o mesmo competente para analisar a admissibilidade do recurso, inclusive quanto à questão da repercussão geral, nos termos do art. $542, \S 1^{\circ}$, do CPC.

Antes que se alegue que o juízo de admissibilidade pelo Tribunal local seria inconstitucional, deve-se lembrar de que contra a decisão de inadmissibilidade cabe agravo de instrumento o que garante que a causa será apreciada pelo STF. Aliás, a possibilidade de interposição desse recurso é justamente o que confere constitucionalidade ao exercício do juízo de admissibilidade pelo Tribunal a quo. Mesmíssimo princípio foi adotado pelo nosso Tribunal de cúpula ao apreciar a constitucionalidade do art. 557.

Outro tema polêmico refere-se ao quórum de votação, uma vez que se for negada a existência de repercussão geral em determinado caso, o Tribunal deverá se manifestar por dois terços de seus membros, de forma similar ao que ocorria com relação à arguição de relevância. Partindo-se de tal premissa, seria necessário um quórum maior (oito Ministros) para apreciar um dos requisitos de admissibilidade do que para se dar provimento a um recurso extraordinário.

Ainda no artigo 543-A, o $\S 5^{\circ}$ confere eficácia vinculante às decisões que negarem repercussão geral a determinados temas, impondo que a decisão valha para todos os recursos sobre idêntica matéria, que serão indeferidos liminarmente. Aquelas outras que decidam pela presença da repercussão não assumirão a mesma eficácia em relação a outros recursos que tratem do mesmo tema.

$\mathrm{O} \S 6^{\circ}$ inova ao prever a intervenção de amicus curiae, a ser autorizada pelo relator do RE, na análise da repercussão geral. Convém destacar, por oportuno, que não pode o terceiro formular alegações sobre o mérito a fim de ver provido ou não o recurso

\footnotetext{
${ }^{63}$ BARIONI, Rodrigo. O recurso extraordinário e as questões constitucionais de repercussão geral. WAMBIER, Teresa Arruda Alvim (Coord.). Reforma do Judiciário. São Paulo: Ed. Revista dos Tribunais, 2005. p. 724.

${ }^{64}$ BERMUDES, Sérgio. A Reforma do Judiciário pela Emenda Constitucional $N^{o} 45$. Rio de Janeiro: Forense, 2005. p. 56.
} 
extraordinário, matéria privativa dos integrantes da relação jurídico-processual e aos terceiros juridicamente interessados. ${ }^{65}$

Por fim, o art. 543-A, em seu $\S 7^{\circ}$, determina que o resumo da decisão sobre a repercussão geral conste de ata que deve ser publicada no Diário Oficial, valendo então como se acórdão fosse.

Outras interessantes inovações encontram-se no novo artigo 543-B, do Código de Processo Civil. A regulamentação do referido dispositivo ocorreu por meio da Emenda Regimental no 21/07 do STF, a qual, especificamente em relação ao procedimento que deveria ser adotado em processos múltiplos, conferiu nova redação ao art. 328 do RISTF.

O caput e o parágrafo primeiro do artigo 543-B falam que, havendo diversos recursos extraordinários que externem controvérsia idêntica, caberá ao tribunal recorrido selecionar um ou alguns recursos - os quais servirão de paradigma - e enviá-lo(s) ao STF para que essa corte suprema decida se, naquele caso, a questão constitucional debatida tem ou não a repercussão geral exigida pela nova lei. O dispositivo em comento apenas se aplica aos recursos extraordinários já admitidos no juízo a quo.

Assim, julga-se um ou alguns recursos quanto à repercussão geral e, negada a existência da mesma, os recursos sobrestados na instância $a$ quo sequer são apreciados pela corte suprema. Contudo, parece ser imprescindível que o Presidente ou vice do tribunal $a$ quo profira decisão interlocutória nos processos sobrestados, negando seguimento aos mesmos por força da decisão paradigmática do STF, já que a parte prejudicada ainda poderia interpor, contra essa decisão do presidente ou vice, o agravo de instrumento do artigo 544 para rever essa decisão, buscando demonstrar, por exemplo, que o seu recurso não veicula matéria idêntica àquele examinado e ao qual foi negada a repercussão geral.

O $5^{\circ}$ do art. 543-B, bem como o artigo $3^{\circ}$ da Lei 11.418/06, dispõem que caberá ao Regimento Interno do STF estabelecer as normas necessárias à execução da lei da repercussão geral, bem como dispor sobre as atribuições dos Ministros, Turmas e outro órgãos do tribunal. Nota-se, pois, que muitos aspectos de detalhamento da nova legislação serão ainda preenchidos e delineados pelo RISTF.

\footnotetext{
${ }^{65}$ Destacamos posicionamento de Athos Gusmão Carneiro para quem a atuação do amicus curiae no processo não passaria de uma espécie atípica de intervenção de terceiros, "com características peculiares, inclusive porque não necessita demonstrar interesse jurídico na solução da demanda, embora deva ostentar representatividade adequada e suficiente". (CARNEIRO, Athos Gusmão. Intervenção de terceiros. São Paulo: Saraiva, 2008. p. 201).
} 
$\mathrm{O}$ art. 543-B demonstra uma tendência que vem sendo adotada pelo STF nos casos em que envolvam demandas tributárias, previdenciárias e administrativas de promover a análise das questões ventiladas em Recurso Especial de forma objetiva, estendendo os efeitos da decisão proferida a todos os recursos extraordinários que versem sobre matéria idêntica.

Longe de ambicionar exaurir o tema, o presente trabalho visa analisar essa inovação trazida pelo constituinte derivado e evidenciar que a repercussão geral, além de funcionar como um filtro para diminuir o número de recursos extraordinários possui também o escopo de firmar o papel do Supremo Tribunal Federal como Corte Constitucional e não como simples instância revisora.

Há, no direito estrangeiro, institutos análogos à repercussão geral. No sistema americano, por exemplo, após o Judicial Reform Act de 1988 eliminou-se quase a totalidade dos recursos, uma vez que prevê referida lei que um processo só pode chegar à Suprema Corte por meio do certiorari.

O writ of certiorari, anota Ives Gandra, é, fundamentalmente, uma solicitação encaminhada à Corte, onde a parte expõe as razões pelas quais os juízes deveriam aceitar julgar um caso em particular. O critério essencial na escolha dos casos é o de sua importância, assim ponderada, de forma discricionária. ${ }^{66}$

Após, a Corte superior dá uma ordem a uma Corte inferior, no sentido de que lhe remeta um determinado caso, para que seja revisto. No caso, diante da latente discricionariedade na seleção do caso que será analisado, o que existe não é um recurso como conhecemos e sim "uma petição, na qual se pleiteia que a corte faça a carta requisitória, ‘chamando' os autos do caso para si!". ${ }^{67}$

Na Alemanha, por sua vez, o instituto que se assemelha à repercussão geral é a Verfassungsbeschwerde ou, em tradução livre à língua portuguesa, "reclamação constitucional", que apresenta feições de ação constitucional específica. A reclamação constitucional alemã pode ser formulada por qualquer pessoa que possua um direito fundamental ofendido por medidas adotadas pelas autoridades públicas ou por decisões judiciais, desde que esgotadas todas as instâncias ordinárias, não sendo necessária a

\footnotetext{
${ }^{66}$ MARTINS FILHO, Ives Gandra da Silva. O critério de transcendência no recurso de revista. Brasília. Disponível em <http://www.planalto.gov.br/ccivil_03/revista/Rev_20/artigos/IvesGandra_rev20.htm>. Acesso em 04 jun. 2010.

${ }^{67}$ Cf. CARMONA, Carlos Alberto. Recurso extraordinário: uma análise do acesso do Supremo Tribunal Federal, cit., p. 32.
} 
formulação prévia de reclamação a uma corte estadual. Tal qual ocorre com a repercussão geral, a reclamação constitucional alemã passa por fase precedente de admissibilidade, por meio da qual se analisa a importância fundamental constitucional da questão, cuja decisão é irrecorrível, sendo que somente após sua admissão se analisa o mérito, cabendo ressaltar que as decisões têm efeito vinculante. ${ }^{68}$

\subsubsection{Julgamento do recurso especial por amostragem}

As hipóteses de cabimento do recurso especial estão previstas no art. 105, III, da Constituição Federal de 1988, sendo tal recurso de direito estrito destinado a atos judiciais que configurem “causas decididas em única ou última instância”. Tais causas abrangem não apenas as questões de mérito, como também as processuais e referem-se tanto às decisões finais quanto às interlocutórias, desde que presente o requisito da definitividade, isto é, impossibilidade de recurso nas instâncias ordinárias, ressalvado o cabimento de embargos de declaração.

Em razão do acúmulo de recursos nos tribunais, a Lei 11.672/2008 trouxe para o julgamento do recurso especial um mecanismo semelhante ao previsto na lei que regulamentou a Repercussão Geral nos Recursos Extraordinários (Lei 11.418/06). Por delegação da lei $\left(\$ 9^{\circ}\right.$, do art. 543-C), o STJ regulamentou o processamento e o julgamento dos recursos especiais repetitivos por intermédio da resolução no 8/2008.

Busca a Lei dos Recursos Repetitivos trazer maior celeridade no processamento dos Recursos Especiais que versem sobre a mesma questão de direito. Trata-se de "filtro" destinado a limitar os casos sujeitos à apreciação pelo STJ e aplica-se quando houver multiplicidade de Recursos Especiais, com tese idêntica, isto é, debatendo a mesma questão jurídica.

Nesses casos, o presidente do tribunal a quo (TJ e TRF), ao constatar a multiplicidade de recursos análogos, admitirá apenas um ou alguns representativos da polêmica (amostras), sobrestando os demais até a decisão do STJ. Os próprios ministros, verificando a multiplicidade, podem escolher as amostras, sobrestando os demais.

\footnotetext{
${ }^{68}$ VIANA, Ulisses Schwarz. A repercussão geral e a Verfassungsbeschwerde. Revista Jurídica Consulex, ano 13, n. 290, p. 51-53, 15 fev. 2009.
} 
Nessa hipótese, comunicarão aos tribunais locais para que se proceda à suspensão dos demais recursos idênticos.

Percebe-se, assim, um sistema de dupla filtragem recursal, sendo que apenas subsidiariamente caberá ao Ministro Relator do STJ a seleção do recurso repetitivo que será julgado, o que ocorrerá somente quando o presidente do Tribunal originário deixe passar algum recurso especial que possa ser caracterizado como repetitivo.

Selecionadas as amostras e suspensos os recursos idênticos, o relator do STJ poderá requisitar informações por escrito ao Tribunal a quo acerca de todos os casos que apresentam a mesma questão controvertida, no intuito de perquirir a real assimilação entre as causas.

Observa-se ser extremamente relevante a adequada escolha do recurso-piloto, isto é, do recurso afetado para julgamento por amostragem ${ }^{69}$, devendo a escolha recair sobre casos em que exista discussão prévia, com a devida reflexão e amadurecimento a respeito do tema, bem como deve haver o correto sobrestamento das demais impugnações.

Após a verificação da questão de direito, será proferida decisão com o intuito de uniformizar a jurisprudência do Superior Tribunal de Justiça sobre a matéria, sendo este entendimento aplicado aos demais processos os quais restaram sobrestados nos Tribunais, aguardando o julgamento do recurso piloto.

No tocante à indagação acerca de quais questões podem ser consideradas idênticas, tem-se que questões fáticas e que exijam dilação probatória não terão espaço no âmbito do recurso especial, restando a matéria exclusivamente jurídica, particularmente a de direito federal.

Aponta o $\S 4^{\circ}$ do novo art. 543-C a possibilidade da intervenção de amicus curiae, contudo, é a norma silente no tocante às formalidades necessárias para que ocorra tal intervenção.

\footnotetext{
69 “O novo artigo traz consigo uma séria complicação, pois deverá, no mínimo, o relator ser cauteloso quanto à identificação de ser ou não os casos análogos. Impondo, assim, uma responsabilidade maior ao presidente do Tribunal de origem em tomar os cuidados necessários a fim de não ocorrer em injustiça, pois, não obstante a esfera de recursos extraordinários (in casu recurso especial) tratar unicamente questão de direito (lei federal), cada caso possui um fundo fático distinto, mesmo que semelhante, todavia, jamais teremos controvérsias em que a base fática seja ipsis litteris". (NOGUEIRA, Daniel Moura. A nova sistemática do processamento e julgamento do recurso especial repetitivo, art. 543-C, do CPC. Revista de Processo, São Paulo, v. 33, n. 164, p. 238, out. 2008).
} 
Daniel Moura Nogueira pondera, com razão, que o novo dispositivo faz nascer um efeito suspensivo oblíquo do recurso especial:

Sendo o recurso especial recebido, como regra, apenas no efeito devolutivo e fazendo parte do grupo dos recursos repetitivos análogos, na forma do novo comando do art. 543-C do CPC, terá uma nova sistemática por via oblíqua, na qual o que não era suspenso passará a ser, pois, terá suspensos efeitos por interpretação sistemática do artigo em comento, com os arts. 265 e 266, do mesmo Código, ou seja, nem um ato se praticará. ${ }^{70}$

Há na norma jurídica em comento, a possibilidade de o órgão a quo retratar-se caso a decisão por este proferida seja diversa da firmada pelo STJ (II, §7 ${ }^{\circ}$, artigo 543C, do CPC), amoldando-se ao entendimento firmado pela Corte. Apesar de ser possível o juízo de retratação, caso o órgão originário entenda pela manutenção de sua decisão, ainda que esta seja contrária à da Corte Superior, no âmbito do STJ, de acordo com a Lei dos Recursos Repetitivos o recurso especial interposto contra a decisão da Câmara ou Turma terá a sua admissibilidade examinada para, posteriormente, presentes os requisitos de admissibilidade, ser remetido ao STJ para julgamento (artigo 543-C, $\S 7^{\circ}$, I e II, e $\S 8^{\circ}$, do CPC).

Apesar da similitude entre a Lei dos Recursos Repetitivos e a Lei 11.418/06, que incluiu os artigos 543-A e 543-B, no Código de Processo Civil, há que se ressaltar, no que diz respeito ao recurso especial, que este não possui suporte constitucional como o recurso extraordinário, que foi implementado justamente para regulamentar o disposto no artigo $102, \S 3^{\circ}$, da $\mathrm{CF} / 88$, acrescentado pela $\mathrm{EC} \mathrm{n}^{\circ} 45 / 2004$. Ademais, no que tange à manifestação do membro do Ministério Público, há previsão expressa no artigo 543-C, §5 , do CPC, o que não ocorre no âmbito da Lei 11.418/06 e nem no Regimento Interno do STF.

Por fim, não se pode olvidar que apesar de a Lei 11.672/08 ter alterado apenas o Código de Processo Civil, a mesma é aplicável a todos os recursos especiais repetitivos que veiculem qualquer matéria de direito repetitiva. Com efeito, trata-se de reforma de caráter geral, pertinente à Teoria Geral do Processo, almejando a diminuição da quantidade de processos em trâmite no Superior Tribunal de Justiça, não devendo a novidade se

\footnotetext{
${ }^{70}$ NOGUEIRA, Daniel Moura. A nova sistemática do processamento e julgamento do recurso especial repetitivo, art. 543-C, do CPC, cit., p. 242.
} 
restringir apenas à matéria cível e sim ser aplicada à matéria penal e processual penal repetitiva. $^{71}$

\subsection{Julgamento de improcedência prima facie do art. 285-A do Código de Processo Civil: o escopo da modificação legal}

A Lei 11.277/2006, dentre outras alterações, acrescentou ao CPC o art. 285-A e seus parágrafos, que possuem a seguinte redação: Art. 285-A. Quando a matéria controvertida for unicamente de direito e
no juízo já houver sido proferida sentença de total improcedência em
outros casos idênticos, poderá ser dispensada a citação e proferida
sentença, reproduzindo-se o teor da anteriormente prolatada.
$\S 1^{\circ}$ Se o autor apelar, é facultado ao juiz decidir, no prazo de 5 (cinco)
dias, não manter a sentença e determinar o prosseguimento da ação.
$\S 2^{\circ}$ Caso seja mantida a sentença, será ordenada a citação do réu para
responder ao recurso.

$\mathrm{O}$ artigo em comento potencializa a força dos precedentes judiciais, na medida em que permite que, antes mesmo da citação do réu, o magistrado, quando a matéria controvertida for unicamente de direito e já houver sido proferida sentença de improcedência daquela pretensão em outros casos semelhantes, possa sentenciar de plano, repetindo o teor das sentenças anteriores.

Questionável, nesse ponto, se o dispositivo em comento poderia ser enquadrado como mecanismo apto a unificar a jurisprudência, tal qual ocorre com tantos outros, a saber, exemplificativamente, ações de controle concentrado de constitucionalidade, súmulas vinculantes editadas pelo Supremo Tribunal Federal, incidente de uniformização de jurisprudência (previsto nos artigos 476 a 479 do CPC). Em nosso sentir, referida norma só poderá ser compreendida como instrumento hábil a unificar a jurisprudência (seja de forma direta ou indireta) se entendermos como requisito de sua utilização a necessidade de que a sentença proferida esteja em consonância o entendimento exarado nos Tribunais Superiores, conforme será detalhado adiante. Caso contrário, restará somente como mecanismo aceleratório do procedimento e meio de julgamento de demandas repetitivas.

\footnotetext{
${ }^{71}$ Nesse sentido, diversos são os precedentes do STJ: RESP 200900970925, JORGE MUSSI, STJ - QUINTA TURMA, DJE DATA: 17/12/2010; AGRESP 201000414707, HAROLDO RODRIGUES (DESEMBARGADOR CONVOCADO DO TJ/CE), STJ - SEXTA TURMA, DJE DATA: 23/08/2010.
} 
Indo adiante, antes de passarmos à verificação dos requisitos formais para a aplicação do julgamento de improcedência liminar da lide, convém destacar que o mesmo só poderá ocorrer na fase inicial do processo, isto é, após a análise preliminar da petição inicial, desde que presentes na hipótese as condições da ação e, por ora, determinados os pressupostos processuais. Constatando o magistrado a presença de defeito sanável, determinará que o autor emende a inicial no prazo de dez dias, sob pena de indeferimento (art. 284, parágrafo único, CPC). Em outras palavras, somente deverá proceder o juiz ao julgamento de improcedência prima facie se presentes os pressupostos processuais e condições da ação. Caso contrário, caberá ao magistrado proferir sentença sem resolução de mérito (art. 267 do CPC).

$\mathrm{O}$ art. 285-A do CPC configura mecanismo apto a evitar o desperdício de atividade jurisdicional e administrativa, tornando o sistema processual brasileiro mais célere e efetivo. $^{72}$

Trata-se o dispositivo em comento de hipótese de julgamento liminar de improcedência, em que ocorre dispensa de citação do demandado. Nesse caso, há supressão da fase instrutória sob a justificativa de ocorrência de frequente reprodução da matéria (predominantemente de direito), posta em juízo. ${ }^{73}$

Convém destacar que o procedimento ordinário, em linhas gerais, é composto pela fase postulatória, que compreende a petição inicial e as possíveis respostas do réu, fase saneadora, instrutória, decisória, liquidação e cumprimento de sentença. Provocada a jurisdição, por meio da petição inicial, o juiz pode adotar determinadas atitudes, tais como: proceder à análise preliminar acerca dos pressupostos processuais, das condições da ação, bem como da existência de eventuais circunstâncias que possibilitem a resolução liminar

\footnotetext{
${ }^{72}$ De acordo com Gustavo Martins dos Santos: “A introdução do art. 285- A no CPC pela Lei na 11.277/2006 justifica-se, em tese, pelas metas institucionais de dar mais celeridade ao processo, desafogando a Justiça, bem como prestigiar o principio da economia processual, a fim de evitar que um processo fadado ao insucesso percorra longo caminho até o inevitável desfecho desfavorável ao autor. Na exposição de motivos do respectivo projeto de lei, apresentou-se como objetivo da nova norma conferir eficiência à tramitação de feitos judiciais e evitar a morosidade que atualmente caracteriza a atividade jurisdicional". (SANTOS, Gustavo Martins dos. A sentença liminar do artigo 285-A do CPC e a celeridade processual: uma abordagem à luz dos princípios da isonomia, do acesso à justiça e do devido processo legal. Revista da Seção Judiciária do Rio de Janeiro, Rio de Janeiro, n. 26, p. 72, dez. 2009).

${ }^{73}$ Pertinente a esse respeito se faz o comentário de Luiz Guilherme Marinoni: “(...) é preciso dar atenção à multiplicação das ações que repetem litígios calcados em fundamentos idênticos, solucionáveis unicamente a partir da interpretação da norma. A multiplicação de ações desta natureza, muito frequente na sociedade contemporânea, especialmente nas relações travadas entre o cidadão e as pessoas jurídicas de direito público ou privado - como aquelas que dizem respeito à cobrança de um tributo ou à interpretação de um contrato de adesão - geram, por consequencia lógica, mais trabalho à administração da justiça, tomando de forma absolutamente irracional, tempo e dinheiro do Poder Judiciário”. (MARINONI, Luiz Guilherme. Ações repetitivas e julgamento liminar, cit., p. 56).
} 
do mérito. É nesta oportunidade, ainda, que o magistrado emite provimento determinando a citação. Pode ocorrer, todavia, que analisando o feito entenda o juiz ser o caso de emissão de provimento negativo do direito de ação ou mesmo do direito material.

$\mathrm{O}$ artigo 285-A do CPC se coaduna com o princípio informativo da economia processual à medida que ao prever, num primeiro momento, dispensa da citação, suprime a concessão de prazo conferido para a resposta do réu e o tempo necessário ao seu exame. Há, assim, nítida redução do caminho procedimental no juízo de primeiro grau, uma vez que o decurso de todo esse procedimento pode levar meses ou anos. Ademais, não se pode negar evidente redução de custos, já que inicialmente não será necessária a contratação de advogado pelo réu, não havendo que se falar, também, em condenação na sucumbência do autor. Ressalte-se, ainda, economia de recursos financeiros do Poder Judiciário com pessoal e equipamentos.

Sopesando-se os prós e contras do dispositivo em comento, conclui-se tratar de técnica efetiva que salvaguarda os direitos do réu e prestigia a economia processual já que dispensa o réu de gastos de energia, tempo e dinheiro com honorários advocatícios. ${ }^{74}$

De outra banda, Umberto Bara Bresolin traz oportunas ponderações sobre o artigo em comento, ao destacar que se houver recurso em face da sentença de improcedência proferida com fundamento no art. 285-A e, convencendo-se de seu desacerto, o juiz se retratar, determinando o regular prosseguimento do feito, ou ainda, caso resolva manter o julgado e o Tribunal anular a sentença, determinando o retorno dos autos ao primeiro grau, terá havido grande desperdício de tempo. ${ }^{75}$

Compreendemos os eventuais problemas decorrentes da aplicação da norma suscitados pelo autor e entendemos que a aplicação da norma do art. 285-A do CPC, deve se dar com cautela a fim de se evitar que na má aplicação do dispositivo ocorram algumas violações no caso concreto.

O direito processual brasileiro, atento aos princípios da economia processual e instrumentalidade das formas, tem evoluído de maneira correta para a inviabilidade do prosseguimento de demandas e recursos sabidamente condenados a desfechos desfavoráveis.

\footnotetext{
${ }^{74} \mathrm{Cf}$. BONDIOLI, Luís Guilherme Aidar. O julgamento liminar de improcedência da demanda da óptica do réu (art. 285-A do CPC). Revista Jurídica, Porto Alegre, v. 56 n. 367, p. 12, maio 2008.

${ }^{75}$ BRESOLIN, Umberto Bara. Considerações sobre o artigo 285-A do Código de Processo Civil. In: CARMONA, Carlos Alberto (Coord.). Reflexões sobre a reforma do Código de Processo Civil. 1. ed. São Paulo: Atlas, 2007. v 1, p. 386.
} 
O dispositivo legal está alicerçado na noção de que já tendo o Poder Judiciário fixado reiteradamente o conteúdo de determinada decisão, torna-se desnecessário prosseguir em processo repetitivo para obtenção de semelhante resultado. Como se verá, o julgamento de improcedência prima facie configura técnica a ser empregada de forma excepcional no sistema estando, portanto, atrelada à presença de determinados requisitos previamente estipulados em lei.

A finalidade da alteração legislativa em comento é, na medida em que autoriza que o primeiro ato do magistrado no processo seja o de proferir julgamento definitivo do mérito da demanda, agilizar o julgamento e evitar o infundado gasto de energia com as causas repetitivas. Trata-se de exemplo de técnica de simplificação e aceleração procedimental, por meio da qual se busca desafogar o juízo de primeira instância.

Tal mecanismo, conforme sabiamente pressagiou Ada Pelegrini Grinover, “rompe certamente com os princípios e regras do processo civil tradicional". ${ }^{76}$ Deste modo, verificado o peso do excessivo número de demandas repetitivas para a crise do Poder Judiciário é que se buscará ao longo do presente trabalho analisar a relevância, utilidade e a compatibilidade do artigo 285-A do Código de Processo Civil, introduzido pela Lei $\mathrm{n}^{\circ}$ 11.277/2006, no ordenamento jurídico processual, como mecanismo de combate à morosidade do processo, em especial aqueles que veiculam teses repetitivas.

\footnotetext{
${ }^{76}$ GRINOVER, Ada Pellegrini. Mudanças estruturais no processo civil brasileiro. Revista IOB de Direito Civil e Processo Civil. Porto Alegre:, v. 8, n. 44, p. 51, nov./dez. 2006.
} 


\section{CAPÍTULO II. JULGAMENTO DE IMPROCEDÊNCIA PRIMA FACIE DE DEMANDAS REPETITIVAS: INTERPRETAÇÃO E ABRANGÊNCIA DO DISPOSTO NO ART. 285-A DO CPC}

\subsection{Sentença de improcedência prima facie do Art. 285-A do Código de Processo Civil: um novo momento para o julgamento de demandas repetitivas}

A introdução do art. 285-A no Código de Processo Civil pela edição da Lei $n^{\circ}$ 11.277, de 7 de fevereiro de 2006 é uma das inovações mais expressivas da terceira etapa da Reforma do Código de Processo Civil ao conferir racionalidade ao julgamento de processos repetitivos.

O relativo projeto de lei, de autoria do Poder Executivo, ao tramitar na Câmara dos Deputados assumiu o $\mathrm{n}^{\mathrm{o}} 4.728 / 2004$, e teve por Relator o Deputado João Almeida que apresentou substitutivo, acolhendo a única sugestão de emenda ao texto original, do Deputado Roberto Magalhães, no sentido de suprimir a expressão "em processos repetitivos e sem qualquer singularidade”, inserida no caput do art. 285-A, bem como substituindo a palavra “cassar" contida no $\S 1^{\circ}$ do artigo em comento, bastante criticada por seu cunho autoritário, pela expressão "não manter". ${ }^{77}$

No Senado Federal, a proposição tramitou como Projeto de Lei da Câmara nº 101, de 2005, tendo como relator o Senador Aloizio Mercadante, o qual opinou pela aprovação do projeto, havendo a determinação tão somente de supressão da palavra “por” existente no $\S 1$, mantendo-se, no mais os termos do substitutivo da Câmara dos Deputados. Na sequencia, a Lei 11.277 foi sancionada em 07/02/2006, sendo sua publicação ocorrida em 22/02/2006.

\footnotetext{
${ }^{77}$ Eis a redação original do art. 285-A, antes de sofrer as alterações, in verbis: “Art. 285-A. Quando a matéria controvertida for unicamente de direito, em processos repetitivos e sem qualquer singularidade, e no juízo já houver sentença de total improcedência em caso análogo, poderá ser dispensada a citação e proferida sentença reproduzindo a anteriormente prolatada. \$ 1 o Se o autor apelar, é facultado ao juiz, no prazo de cinco dias, cassar a sentença e determinar o prosseguimento da demanda. § 20 Caso mantida a sentença, será ordenada a citação do réu para responder ao recurso." (CÂMARA DOS DEPUTADOS. Projeto de Lei n. ${ }^{\circ}$ 4.728, de 2004.2 Disponível em: <http://www.camara.gov.br/proposicoesWeb/prop_mostrarintegra;jsessionid=8B69B11D297D0322DB9B0 153DB0F8AEC.node2? codteor=272449\&filename=Avulso+-PL+4728/2004>. Acesso em: 23 out. 2012).
} 
Quanto à posição topográfica do art. 285-A, no Código de Processo Civil, verificase que o dispositivo em comento está inserto na Seção I (Dos requisitos da petição inicial) do Capítulo I (Da petição inicial) do Título VIII (Do procedimento ordinário) do seu Livro I (Do processo de conhecimento). Deste modo, o art. 285-A permite ao juiz ao invés de determinar a citação do réu a possibilidade de, desde logo, presentes os requisitos especificados na norma, julgar improcedente o pedido do demandante.

O procedimento ordinário do Código de Processo Civil brasileiro está estruturado, basicamente, em quatro fases lógicas, as quais são interligadas: postulatória, saneamento, instrutória e decisória (sendo esta última o momento habitual para o julgamento do pedido). Há, é bom frisar, outros procedimentos que, de acordo com a natureza da questão substancial debatida entre as partes, assumem contornos distintos, com eliminação ou, ainda, maior grau de centralização em determinadas fases procedimentais.

$\mathrm{O}$ art. 285-A, do CPC leva a uma concentração de atos processuais ainda na fase postulatória, na qual a parte autora manifesta sua pretensão através da exordial e o magistrado, caso se façam presentes os requisitos exigidos em lei, pode extinguir o feito, com resolução de mérito, antes mesmo da formação da relação jurídica processual triangular.

Atualmente, proposta a ação (art. 263, do CPC), pode o magistrado adotar uma das seguintes condutas: i) declarar, caso presente uma das hipóteses dos arts. 134 e 135 do CPC, seu próprio impedimento ou suspeição; ii) reconhecer, de ofício, a sua incompetência absoluta, determinando a remessa dos autos ao juízo competente; iii) declarar, de ofício, a nulidade de cláusula de eleição de foro abusiva em contrato de adesão, remetendo os autos ao foro competente; iv) determinar a emenda da inicial (quando houverem vícios sanáveis); v) indeferir a inicial, quando nesta houver vício insanável ou quando houver vício sanável, o autor não proceder à sua emenda; vi) deferir a petição inicial e determinar a citação do réu; vii) nos processos repetitivos, se já houver sentenças anteriores de total improcedência no juízo, o juiz pode proferir sentença desde logo, julgando totalmente improcedente o pedido, repetindo os argumentos das sentenças anteriores, sem a necessidade de citar o réu (art. 285-A, do CPC). ${ }^{78}$

\footnotetext{
${ }^{78}$ DONIZETTI, Elpídio. Curso didático de direito processual civil. 12. ed. Rio de Janeiro: Lumen Juris, 2009. p. 326-330.
} 
Assim, com a chegada da Lei 11.277/2006, que introduziu o art. 285-A ao Código, três são os momentos para que o juiz julgue, com apreciação do mérito, o pedido formulado pela parte autora, quais sejam: ao despachar a petição inicial, na fase postulatória (art.285-A do CPC), no chamado julgamento antecipado da lide, na fase saneadora (art. 330 do CPC) e, ainda, na fase decisória, após a fase de instrução, nos termos do art. 456 do CPC. Aqui cabe lembrar que o Código de Processo Civil de 1.939 só admitia o julgamento do mérito mediante realização de audiência percebendo-se, assim, a evolução legislativa que tal disciplina tem recebido.

A aplicação do julgamento prévio de improcedência da lide só poderá ocorrer na fase inicial do processo, isto é, após a análise preliminar da petição inicial, desde que presentes na hipótese as condições da ação e os pressupostos processuais. Constatando o magistrado a presença de defeito sanável, determinará que o autor emende a inicial no prazo de dez dias, sob pena de indeferimento (art. 284, parágrafo único, CPC). Em outras palavras, o juiz somente deverá proceder ao julgamento de improcedência prima facie se presentes os pressupostos processuais e condições da ação. Caso contrário, caberá ao magistrado proferir sentença sem resolução de mérito (art. 267 do CPC).

O julgamento antecipado da lide, por sua vez, ocorre em estágio mais avançado do processo e ocorre em duas hipóteses, que não precisam ser simultâneos, quais sejam: i) quando a matéria é só de direito ou é de direito e de fato, mas não exige produção de prova em audiência (ex.: fato incontroverso, confessado, notório ou provado por documento), ii) quando houver revelia incidindo a presunção de veracidade dos fatos.

Tal dispositivo permite uma simplificação significativa do procedimento ordinário, uma vez que é suprimida a fase instrutória, já que dispensável para a solução do caso concreto, passando o juiz a analisar o objeto do processo, na fase destinada à decisão de saneamento, em inegável técnica de economia processual.

$\mathrm{O}$ art. 285-A do CPC se assemelha com o julgamento antecipado da lide previsto no art. 330 do CPC na medida em que ambos destinam-se ao julgamento abreviado do mérito, desde que presentes certos requisitos, sendo técnicas de aceleração do procedimento ordinário.

Por outro lado, essas modalidades de julgamento se diferem quanto à necessidade de citação, necessidade de existência ou não de casos idênticos anteriormente resolvidos pelo mesmo juízo, bem como quanto ao resultado final da sentença de mérito, uma vez que no julgamento antecipado da lide o feito pode ter sentença de procedência ou 
improcedência, enquanto a norma do art. 285-A só comporta o julgamento de improcedência. Deste modo, se o juiz pretender julgar procedente a demanda repetitiva, não poderá fazê-lo sem antes proceder à citação do réu, dando-lhe oportunidade para que exerça o contraditório.

A modalidade do julgamento antecipado da lide foi introduzida no Código de Processo Civil de 1.973 e representou grande avanço ao possibilitar a prolação de sentença independente da realização de audiência.

Tal dispositivo, contudo, recebeu, inicialmente, ressalvas por parte da doutrina que via no julgamento antecipado uma ameaça de ofensa às garantias constitucionais processuais, caso não fosse utilizado com prudência. ${ }^{79}$

As críticas formuladas ao art. 330 do CPC não destoam muito daquelas ventiladas a respeito do art. 285-A, posto que evidenciam o receio de parcela da doutrina no que diz respeito às possíveis afrontas às garantias constitucionais processuais em relação ao encurtamento no caminho procedimental em primeira instância. ${ }^{80}$

Observe-se que a redação do artigo 285-A em momento algum limita a sua aplicação a determinado rito processual, razão pela qual balizada doutrina defende a sua utilização de forma bastante ampla. ${ }^{81}$

Com efeito, não vislumbramos óbice para que se estenda essa regra também aos juizados especiais cíveis, já que seu escopo de imprimir maior celeridade e efetividade ao processo está em consonância com os princípios que regem aquele órgão, em especial pela simplificação e desapego ao formalismo em processos de sua competência.

\footnotetext{
${ }^{79}$ Por todos, cf. GRINOVER, Ada Pellegrini. O julgamento antecipado da lide: enfoque constitucional. Revista de Processo, São Paulo, v. 2 n. 5, p. 112, jan./ mar. 1977.

${ }^{80}$ ARAÚJO, Luciano Vianna. 285-A do CPC (julgamento imediato, antecipado e maduro da lide): evolução do sistema desde o Código de Processo Civil de 1939 até 2007. Revista de Processo, São Paulo, v. 33 n. 160, p. 162, jun. 2008.

81 "Processos e procedimentos em que incide a norma. Nada obstante o CPC 285-A se localize topicamente dentro do processo comum ordinário, do Livro do processo de conhecimento, a norma comentada tem natureza de regra geral de processo e procedimento, motivo pelo qual se aplica a toda e qualquer ação, independentemente da competência do juízo e do rito procedimental que se imprima à ação repetida. Assim, pode ser aplicada a regra da improcedência da ação repetida nos processos de conhecimento, cautelar e execução, nos procedimentos comum (ordinário e sumário) e sumaríssimo (v.g., juizados especiais federal e estadual), assim como nas ações que se processam por rito especial (v.g., CPC 890 et seq., mandado de segurança, ação civil pública, ação popular, ação coletiva, ações de locação, ações falências, ação de embargos do devedor etc.) É admissível a aplicação do CPC 285-A nos processos da competência da justiça comum (federal e estadual) e da justiça especial (e.g., justiça do trabalho - CLT 769). A incidência da norma comentada dá-se, também, no âmbito dos tribunais, para as ações de sua competência originária”. (NERY JÚNIOR, Nelson; NERY, Rosa Maria Andrade. Código de Processo Civil comentado e legislação processual civil extravagante em vigor, cit., p. 580-581).
} 
Cabível também nas hipóteses de interposição de embargos à execução, desde que veiculem matéria preponderantemente de direito, sem necessidade de dilação probatória, como é bem comum em sede tributária, ou seja, nos embargos contra a Fazenda Nacional. Não encontramos, ainda, óbice à aplicação do art. 285-A do $C P C$, às denominadas ações cautelares de natureza satisfativa.

Ademais, prevê o artigo 769, da Consolidação das Leis do Trabalho (CLT) a aplicação subsidiária do direito processual comum (CPC principalmente) nos casos em que houver omissão da regulamentação processual trabalhista, desde que haja compatibilidade com o sistema processual trabalhista. Na mesma direção, aponta o artigo 889, da CLT quanto à execução trabalhista. Assim, ainda que não seja omissa a CLT, nada impede que uma norma do Código de Processo Civil que seja considerada mais eficaz possa ser aplicada, em determinados casos, ao processo trabalhista. ${ }^{82}$

\subsection{Institutos semelhantes ao Artigo 285-A do CPC}

$\mathrm{O}$ art. 285-A do CPC, na verdade, não contempla total novidade no cenário jurídico brasileiro, pois antes mesmo do advento da Lei n. 11.277/2006, dois dispositivos já possibilitavam ao juiz o liminar julgamento de improcedência da ação. Com efeito, o art. 269, IV, do CPC, combinado com o art. 295, IV, do mesmo diploma, permite ao juiz o indeferimento da inicial pelo advento da prescrição ou da decadência. A outra hipótese diz respeito ao art. 17 da Lei n. 8.429/92 (Lei de Improbidade Administrativa) que dispõe que o juiz pode, além do indeferimento da inicial em virtude da inconformidade da via eleita ou vícios formais (art. 283 c/c. art. 295 do CPC), julgar a ação improcedente de plano (mérito), desde que convencido da inexistência do ato de improbidade pelos elementos trazidos aos autos. ${ }^{83}$

A possibilidade de julgamento de mérito pelo juiz logo nos primeiros contatos com a petição inicial é, vale frisar, medida excepcional. A primeira hipótese ventilada refere-se

\footnotetext{
${ }^{82}$ No mesmo sentido posiciona-se Fernanda Guedes Pinto: "Incide, ainda, tanto na justiça comum (federal e estadual) como na especial, principalmente na Justiça do Trabalho, onde haverá grande utilidade nas ações previdenciárias, que muitas vezes se caracterizam por ações repetitivas.” (PINTO, Fernanda Guedes. As ações repetitivas e o novel art. 285-A do CPC (racionalização para as demandas de massa). Revista de Processo, São Paulo, v. 32 n. 150, p. 153, ago. 2007).

${ }^{83}$ MARCATO, Antonio Carlos. Crise da Justiça e influência dos precedentes judiciais no direito processual civil brasileiro, cit., p. 209.
} 
à possibilidade de reconhecimento de decadência ou prescrição do direito que a parte autora alude fazer direito através da ação (art. 295, IV, do CPC). Referido artigo faz menção expressa ao art. $219, \S 5^{\circ}$, o qual teve sua redação modificada pela Lei 11.280/2006, passando a ser a prescrição matéria passível de ser reconhecida ex officio pelo juiz nos casos de direitos de qualquer espécie, sejam eles patrimoniais ou não patrimoniais. $^{84}$

O instituto da decadência está previsto expressamente no Novo Código Civil nos arts. 207 a 211, bem como no Código de Defesa do Consumidor, Lei 8.078/90, art. 26, I, II, $\S 1^{\circ}, \S 2^{\circ}$, I e III e $\S 3^{\circ}$. No que diz respeito à prescrição, o Código Civil de 2.002 dispõe em seu art. 189: "Violado o direito, nasce para o titular a pretensão, a qual se extingue, pela prescrição, nos prazos a que aludem os arts. 205 e 206."

Decadência e prescrição são fatos jurídicos que se relacionam com o passar do tempo e se referem à extinção de determinada eficácia jurídica, dado o desinteresse ou inércia do titular do exercício do direito nas relações jurídicas. Em que pese configurem ambos formas de perecimento de direitos subjetivos, tais institutos não se confundem.

A decadência, que se distingue do fenômeno da preclusão temporal, refere-se ao perecimento do direito potestativo (sejam eles disponíveis ou indisponíveis) em razão do seu não exercício no prazo legal ou contratualmente estabelecido. A decadência, mesmo a convencional, é fato que pode ser alegado pelas partes a qualquer tempo e grau de jurisdição, a exemplo do que disciplina o art. 211 do atual Código Civil. Contudo, somente ocorrendo a decadência legal é que poderá o magistrado declará-la, ex officio, nos termos do art. 210 do Código Civil.

A prescrição, por sua vez, refere-se à extinção da pretensão de um direito subjetivo, em razão da inércia do seu titular, em determinado lapso de tempo, desde que ausente qualquer fato ou ato ao qual a lei confira eficácia impeditiva, suspensiva ou interruptiva de curso prescricional, podendo ser reconhecida a qualquer tempo e grau de jurisdição por aquele a quem aproveita.

\footnotetext{
${ }^{84}$ Muitos doutrinadores lançaram críticas a essa alteração. Humberto Theodoro Júnior, a guisa de exemplo, se insurge contra a prescrição ex officio alegando se tratar de interesse disponível da parte e que por tal razão não poderia o Estado invadir a esfera de autonomia da vontade, própria do direito privado. Para referido autor, "melhor mesmo seria revogar, de lege ferenda, a infeliz inovação, mas, enquanto isto não se der, o dever do intérprete e aplicador da lei inovadora será o de buscar minimizar as impropriedades contidas em sua literalidade, e reduzir sua aplicação apenas às hipóteses compatíveis com a natureza, finalidade e sistema da prescrição dentro do direito material". (THEODORO JÚNIOR, Humberto. Curso de direito processual civil: teoria geral do direito processual civil e processo de conhecimento.. 52. ed. Rio de Janeiro: Forense, 2011. v. 1, p. 365).
} 
É bom salientar que o que se extingue é a pretensão alegável em juízo por meio de uma ação, mas não o direito em si considerado. Tanto é assim que é considerado válido o pagamento voluntário da dívida, ainda que prescrita, sendo que a restituição não poderá ser reclamada, a teor do que dispõe o art. 882 do Código Civil.

Com o intuito de compatibilizar o sistema normativo com a nova redação do $\$ 5^{\circ}$ do art. 219 do CPC, o art. 11 da Lei 11.280/06 revogou o art.194 do CC/2002, que estabelecia que o magistrado não poderia conhecer de ofício a ocorrência da prescrição, exceto se em benefício de incapaz. Tal medida busca evitar que o processo tramite de maneira indevida naquelas situações em que o magistrado constata a existência da prescrição, não alegada pela parte.

Importa frisar que a modificação em comento trouxe consigo alguns questionamentos. O primeiro deles refere-se ao momento em que o juiz deverá pronunciar a prescrição, se de imediato ou se num segundo instante, após oportunizar defesa do réu. $\mathrm{O}$ segundo, e mais importante, diz respeito à declaração, de ofício, da prescrição pelo juiz, tendo em vista que o art. 191 do Código Civil, que ainda está em vigor, possibilita à parte a faculdade de renunciar à prescrição. Diante desse quadro, quer nos parecer que o mais adequado seja determinar a citação do réu para manifestar seu interesse em renunciar ou não à prescrição, uma vez que podem existir situações de fato ou de direito de conhecimento privativo das partes, as quais podem obstar a perda da prescrição. ${ }^{85}$

Há várias características típicas no que diz respeito a cada um dos institutos, sendo que a doutrina tem buscado ao longo dos anos encontrar regras que possam, de forma segura, diferenciar tais institutos. ${ }^{86}$ Aponta-se como primeiro grande critério de distinção entre os institutos da prescrição e decadência o fato de que o primeiro atinge as pretensões de natureza condenatória, enquanto que o segundo incide sobre as pretensões de natureza constitutiva que tenham prazo especial de exercício estipulado em lei. ${ }^{87}$ Ademais, e fundamentalmente, distinguem-se entre si pela decadência atingir o direito propriamente dito, isto é, o próprio direito potestativo (cuja principal característica é o estado de sujeição

${ }^{85}$ Cf. CIANCI, Mirna. A prescrição na Lei 11.280, de 2006. Disponível em: <http://www.migalhas.com.br/dePeso/16,MI31614,51045-A+Prescricao+na+Lei+11280+de+2006>. Acesso em: 16 dez. de 2012.

${ }^{86}$ Não se trata de tarefa simples, sendo que Antônio Luiz da Câmara Leal, autor brasileiro que se debruçou sobre o estudo do assunto, chegou a afirmar que distinguir tais institutos é "um dos problemas mais árduos da teoria geral do direito civil." (CÂMARA LEAL, Antônio Luiz da. Da prescrição e decadência. 3. ed. Rio de Janeiro: Ed. Forense, 1978. p. 133).

${ }^{87}$ AMORIM FILHO, Agnelo. Critério científico para distinguir a prescrição da decadência e para identificar as ações imprescritíveis. In: NERY JÚNIOR, Nelson; NERY, Rosa Maria Andrade (Orgs.). Responsabilidade civil: teoria geral. São Paulo: Ed. Revista dos Tribunais, 2010. v. 1, p. 791-798. 
que o seu exercício cria para outras pessoas, independentemente e, até mesmo, contra a vontade dessas), enquanto que a prescrição atinge a pretensão, isto é, possibilidade de exigir de outrem, de forma coercitiva, o cumprimento de um dever jurídico, continuando a existir o direito subjetivo. ${ }^{88}$

Tanto a prescrição quanto a decadência constituem matérias preliminares de mérito e estão sujeitas a julgamento de mérito, de acordo com o art. 269, IV e o art. 295, IV, ambos do CPC. Ao se permitir que sejam pronunciadas de ofício pelo juiz, surge a possibilidade de se julgar o mérito antes mesmo da citação do réu, já que o juiz poderá declarar tanto a decadência legal quanto a prescrição quando da análise acerca do recebimento da petição inicial. ${ }^{89}$

O que torna o art. 285-A um mecanismo peculiar e o distingue da hipótese aqui ventilada é o fato de que naquele caso o processo é extinto com resolução do mérito por meio de uma sentença genuinamente de mérito (art. 269, I, do CPC), enquanto que ao extinguir o processo com resolução do mérito, reconhecendo a decadência e a prescrição (art. 269, IV, CPC), profere o juiz “uma sentença de mérito por equiparação (ou uma falsa sentença de mérito), já que o julgador não aprecia o pedido deduzido pelo autor". 90

Nas ações de improbidade administrativa também já existia a possibilidade de julgamento imediato pela improcedência com análise do mérito, caso o julgador estivesse convencido da inexistência de ato de improbidade pelos elementos dos autos, de acordo com a disciplina do art. 17, da Lei $n^{\circ} 8.429 / 92$, com a redação dada pela Medida Provisória $\mathrm{n}^{\mathrm{o}} 2.225 / 2001{ }^{91}$

A lei de improbidade administrativa pode ser considerada um microssistema por meio do qual se estabeleceu as espécies de atos de improbidade administrativa e suas

\footnotetext{
${ }^{88}$ Maria Helena Diniz assim resume a diferença entre prescrição e decadência no direito civil: "A decadência não seria mais do que a extinção do direito potestativo, pela falta de exercício dentro do prazo fixado, atingindo indiretamente a ação, enquanto a prescrição extingue a pretensão alegável em juízo por meio de uma ação, fazendo desaparecer, por via oblíqua, o direito por ela tutelado que não tinha tempo fixado para o seu exercício. Logo, a prescrição supõe direito já exercido pelo seu titular, existente em ato, mas cujo exercício sofreu obstáculo pela violação de terceiro; a decadência supõe um direito que não foi exercido pelo seu titular, existente apenas em potência.” (DINIZ, Maria Helena. Curso de direito civil brasileiro: teoria geral do direito civil. 24. ed. São Paulo: Saraiva, 2007. v. 1, p. 413).

${ }^{89}$ LUCCA, Rodrigo Ramina de. Resolução liminar do mérito. Revista Dialética de Direito Processual, São Paulo, n. 79, p. 124, out. 2009.

${ }^{90}$ LUCON, Paulo Henrique dos Santos. Prescrição, decadência e processo civil. In: JAIME, Fernando Gonzaga; FARIA, Juliana Cordeiro de; LAUAR, Maira Terra (Coords.). Processo civil: novas tendências: estudos em homenagem ao Professor Humberto Theodoro Júnior. Belo Horizonte: Del Rey, 2008. p. 571.

${ }^{91}$ Dispõe o artigo 17, parágrafo $8^{\circ}$, da Lei 8.429/92: "Recebida a manifestação, o juiz, no prazo de trinta dias, em decisão fundamentada, rejeitará a ação, se convencido da inexistência do ato de improbidade, da improcedência da ação ou da inadequação da via eleita."
} 
respectivas sanções, bem como instrumentos processuais que permitissem dar efetividade à ação de improbidade administrativa.

Improbidade Administrativa corresponde à expressão técnica para a chamada corrupção administrativa, que, sob diversas formas, gera o desvirtuamento da Administração Pública e insulta os princípios da ordem jurídica revelando-se pela obtenção de vantagens patrimoniais indevidas às expensas do erário, pelo exercício nocivo das funções e empregos públicos, através de "ação ou omissão dolosa de agente público ou de quem de qualquer forma concorresse para a realização da conduta, com a nota imprescindível da deslealdade, desonestidade ou ausência de caráter." ${ }^{22}$

A Constituição Federal faz diversas menções à improbidade: art. 14, §9 (ambiciona coibir a improbidade no período eleitoral, possuindo caráter preventivo; art. 15 , inc. $\mathrm{V}$ (trata de suspensão de direitos políticos em caso de improbidade; art. 85, V (elenca dentre os crimes de responsabilidade do Presidente da República o de improbidade; art. 37, § $4^{\circ}$ (elenca rol exemplificativo de algumas medidas punitivas para a improbidade). Nesse sentido, a lei de improbidade administrativa (Lei 8.429/92) surgiu como mecanismo para regulamentar a previsão constitucional constante do art. $37, \S 4^{\circ}$, dando-lhe plena eficácia. Através de tal dispositivo, ampliou-se o rol das modalidades de atos de improbidade administrativa cometidas pelos sujeitos ativos, bem como possibilitou-se a cominação de medidas repressivas mais enérgicas, condizentes com a lesividade do respectivo ato e com maior poder intimidativo. ${ }^{93}$

Para que reste configurado o ato de improbidade é necessário a presença de determinados elementos, a saber: sujeito passivo, sujeito ativo, ocorrência de ato danoso descrito na lei, elemento subjetivo.

A lei de improbidade, em seus artigo $1^{\circ}$, define quem são os sujeitos passivos do ato de improbidade, enquanto que nos artigos $2^{\circ}$ e $3^{\circ}$ trata da titularidade ativa.

Podem compor o polo passivo do ato de improbidade qualquer entidade da Administração pública direta, indireta ou fundacional (Autarquias e Agências Reguladoras, Agências Executivas, Associações Públicas, Fundações, Empresas Públicas e Sociedades de Economia Mista), de qualquer dos poderes dos entes da Federação, pessoa jurídica de

\footnotetext{
${ }^{92}$ NEIVA, José Antonio Lisbôa. Improbidade administrativa: estudo sobre a demanda na ação de conhecimento e cautelar. 2. ed. Rio de Janeiro: Impetus, 2006. p. 13.

${ }^{93}$ FAZZIO JÚNIOR, Waldo. Improbidade administrativa: doutrina, legislação e jurisprudência. São Paulo: Atlas, 2012.p. 13.
} 
direito privado em que o erário participe com mais de $50 \%$ do custeio do patrimônio ou receita anual, além de entidades que recebam subvenção, benefício ou incentivo, fiscal ou creditício de órgãos ou empresas públicas.

No que diz respeito à titularidade ativa do ato de improbidade, são sujeitos o agente público (art. $2^{\circ}$, da Lei 8.429/92) e o terceiro que se beneficia pelo ato de forma direta ou indireta, concorre ou induz à prática do ato de improbidade (art. $3^{\circ}$, da Lei 8.429/92). No primeiro caso fala-se em ato de improbidade próprio, enquanto no segundo diz-se ser o ato de improbidade impróprio ou por equiparação.

O ato improbidade pode se dar por conduta comissiva ou omissiva, no exercício da função pública ou quando a atinge. A lei de improbidade traz em seu Capítulo II, dividido em três seções, as modalidades dos atos de improbidade, quais sejam: aqueles que importam enriquecimento ilícito, os que causam prejuízo ao erário e aqueles que atentam contra os princípios da Administração Pública. De acordo com o art. $9^{\circ}$ constitui ato de improbidade administrativa, configurando enriquecimento ilícito, receber qualquer tipo de vantagem patrimonial indevida em virtude do exercício de atividade pública.

Reza o art. 10 constituir ato de improbidade administrativa que causa lesão ao erário qualquer ação ou omissão dolosa ou culposa que enseje perda patrimonial, desvio, apropriação ou dilapidação dos bens das entidades da administração pública.

Nos termos do art. 11, da Lei $\mathrm{n}^{\mathrm{o}}$ 8.429/92, também configura ato de improbidade administrativa qualquer ação ou omissão que atente contra os princípios da administração pública, violando os deveres de honestidade, imparcialidade, legalidade e lealdade às instituições.

A Lei 8.429/92 prevê a aplicação de sanção independentemente da decisão do Tribunal de Contas (seja favorável ou desfavorável) ou de efetiva lesão ao erário. Tais medidas são de natureza extra penal (civil ou política-administrativa) e variam de acordo com a conduta, a gravidade do ato praticado, bem como o proveito patrimonial alcançado pelo agente. Dentre as medidas cabíveis, destaca-se a suspensão de direitos políticos, perda de função pública, indisponibilidade dos bens, multa civil e ressarcimento ao erário.

É preciso verificar a razoabilidade e a proporcionalidade no que toca à seriedade do ato ímprobo e à imposição das penalidades, as quais podem ser aplicáveis cumulativamente ou não. Ademais, as penalidades constantes da lei de improbidade podem ser aplicadas independentemente de outras sanções previstas em outras leis. 
A aplicação da lei de improbidade administrativa requer, ainda, a presença de elemento subjetivo, qual seja, dolo ou culpa ou, ainda, má-fé por parte do sujeito ativo. ${ }^{94}$

Vale frisar que as ações que visam o ressarcimento de dano ao erário são, segundo a doutrina, imprescritíveis (art. $37, \S 5^{\circ}$ da $\left.\mathrm{CF} / 88\right)^{95}$, mas os demais pedidos prescrevem no prazo do art. 23 da Lei 8.429/92.

Os mecanismos para o controle dos atos de improbidade são o inquérito civil e a ação de improbidade administrativa, de natureza civil. A lei prevê, ainda, algumas medidas cautelares, tais como: sequestro, indisponibilidade de bens e afastamento do agente público.

A ação de improbidade administrativa, com legitimidade ativa concorrente entre o Ministério Público ou pessoa jurídica interessada (isto é, aquelas atingidas pelo ato ímprobo), segue rito híbrido ${ }^{96}$, tendo em vista a existência de um juízo prévio de admissibilidade, que enseja a notificação do requerido ${ }^{97}$, antes do recebimento da inicial, para oferecer resposta por escrito no prazo de 15 dias (defesa preliminar), podendo o juiz rejeitar a ação se convencido da inexistência do ato, da improcedência da demanda ou da inadequação da via eleita.

\footnotetext{
${ }^{94}$ Nesse sentido: "ADMINISTRATIVO E PROCESSUAL CIVIL. ART. 535 DO CPC. ALEGAÇÃO GENÉRICA. SÚMULA 284/STF. IMPROBIDADE ADMINISTRATIVA. INEXISTÊNCIA DE CARACTERIZAÇÃO DE DOLO E MÁ-FÉ. 1. É assente nesta Corte Superior o entendimento segundo o qual, para que seja reconhecida a tipificação da conduta do réu como incurso nas previsões da Lei de Improbidade Administrativa, é necessária a demonstração do elemento subjetivo, consubstanciado no dolo para os tipos previstos nos arts. $9^{\circ}$ e 11 e, ao menos, pela culpa, nas hipóteses do art. 10. 2. No caso dos autos, as premissas fáticas assentadas pela origem dão conta de que o ex-prefeito demitiu irregularmente servidores públicos, sob o entendimento de "estar atendendo às disposições da Lei de Responsabilidade Fiscal, ao reduzir as despesas com pessoal desnecessário". Não havendo comprovação do dolo de prejudicar os lesados, ou favorecer terceiros, dano ao erário, e que, tampouco, "o agente público agiu visando outro fim que não o bem público". 3. A má-fé, consoante cediço, é premissa do ato ilegal e improbo; e a ilegalidade só adquire o status de improbidade quando a conduta antijurídica fere os princípios constitucionais da Administração Pública, coadjuvados pela má-intenção do administrador. Precedente: REsp 1.149.427/SC, Rel. Min. Luiz Fux, Primeira Turma, julgado em 17.8.2010, DJe 9.9.2010. Agravo regimental improvido." (AgRg no AREsp 81.766/MG, Rel. Ministro HUMBERTO MARTINS, SEGUNDA TURMA, julgado em 07/08/2012, DJe 14/08/2012).

95 "As ações de ressarcimentos de danos decorrentes de atos de improbidade administrativa, portanto, estão sujeitas a prazo prescricional e, sem minimizar a argúcia dos que defendem a tese oposta - a da não prescrição dessa pretensão administrativa - lembro que a fixação desse prazo é um modo de não se premiar a inércia da Administração, sempre tão alerta em impedir as iniciativas particulares contra si, valendo-se dos mais variados argumentos." (ROCHA, Cesar Asfor. Breves reflexões críticas sobre a ação de improbidade administrativa. Ribeirão Preto: Migalhas, 2012. p. 47-48).

${ }^{96}$ Cf. FAZZIO JÚNIOR, Waldo. Improbidade administrativa: doutrina, legislação e jurisprudência, cit., p. 434.

${ }^{97}$ Cabe frisar que o STJ já manifestou entendimento no sentido de que a "ausência da notificação prévia tratada no art. $17, \S 7^{\circ}$, da Lei 8.429/1992 somente acarreta nulidade processual se houver comprovação de efetivo prejuízo, de acordo com a parêmia pas de nullité sans grief." (REsp 1174721/SP, Rel. Ministro HERMAN BENJAMIN, SEGUNDA TURMA, julgado em 27/04/2010, DJe 29/06/2010).
} 
Podem figurar no polo passivo de uma demanda de improbidade, o agente público e os terceiros beneficiados com o ato ímprobo. Contudo, não há que se falar em litisconsórcio passivo necessário por não estarem presentes nenhuma das hipóteses pressagiadas no art. 47 do CPC (disposição legal ou relação jurídica unitária).

Haverá indeferimento com juízo de mérito quando, pela simples leitura da inicial e da defesa prévia apresentada pelo requerido, houver persuasão do magistrado acerca da inexistência de ato ímprobo que se enquadre nos casos previstos em lei, bem como quando o juiz se convence da improcedência da demanda. Por outro lado, haverá julgamento sem análise de mérito nos casos de inadequação da via eleita, isto é, quando "da narração dos fatos não decorre, logicamente, a conclusão". ${ }^{98}$

Somente após findo o juízo preliminar de admissibilidade da ação civil de improbidade, com o recebimento da inicial, oportunidade em que o magistrado expressa a plausibilidade do pedido, é que terá início o rito ordinário, onde então, após dilação probatória, será analisada a existência ou não de ato de improbidade administrativa a ser apenado.

$\mathrm{O} \S 9^{\circ}$ do art. 17 prevê que, recebida a inicial, o juiz mandará citar o réu para que apresente sua defesa. A decisão de recebimento da inicial de uma ação de improbidade administrativa, dada a sua relevância e seriedade, está sujeita a agravo de instrumento, a teor do que dispõe o art. 17, § 10 da Lei 8.429/92, já que indica, inicialmente, que ao magistrado pareceu "que aquele imputado (promovido ou réu) agiu mesmo de forma ímproba, sendo o caso, portanto, de submetê-lo a processo, para se apurar as circunstâncias em que cometeu aquele ilícito, para que se possa, no final, impor-lhe a sanção que a lei prevê". 99

$\mathrm{O}$ art. $17, \S 8^{\circ}$, da Lei 8.429/92, ao contrário do que acontece com a sentença proferida com fundamento no art. 285-A do CPC não apresenta um julgamento prévio do mérito puro, já que o julgamento ocorre após a notificação para apresentação de defesa prévia, ou seja, após manifestação de todas as partes. ${ }^{100}$ Há, é bom frisar, aqueles que entendem que apesar do teor do disposto $\S 8^{\circ}$, seria admissível o indeferimento da petição inicial, com julgamento de mérito, sem que houvesse prévia determinação de notificação, quando já se vislumbrasse não se configurar como ímprobo ato assim descrito na causa de

\footnotetext{
${ }^{98}$ FAZZIO JÚNIOR, Waldo. Improbidade administrativa: doutrina, legislação e jurisprudência, cit., p. 453. ${ }^{99}$ ROCHA, Cesar Asfor. Breves reflexões críticas sobre a ação de improbidade administrativa, cit., p. 38.

${ }^{100}$ LUCCA, Rodrigo Ramina de. Resolução liminar do mérito, cit., p. 121.
} 
pedir. Quanto ao recurso cabível para o caso, seria aplicável a sistemática do $\S 2^{\circ}$ do art. 285-A do CPC. ${ }^{101}$

Apesar do sistema já admitir o julgamento liminar da improcedência da ação nos casos citados (prescrição/decadência e improbidade administrativa), foi somente com a edição do art. 285-A do CPC, que houve uma "generalização de sua aplicação para todas as ações cíveis (incluindo aqui as trabalhistas) que, para seu deslinde, independam da produção de provas. "102

Cumpre salientar que o projeto do novo Código de Processo Civil (PL 8046/10), que atualmente tramita na Comissão Especial da Câmara dos Deputados, prevê em seu art. $307, \S 1^{\circ}$, que trata do julgamento de improcedência de plano do pedido, a incorporação da hipótese prevista no art. 295, IV, do CPC vigente (prescrição/decadência).

\subsection{Julgamento de improcedência prima facie: um mecanismo “tupiniquim"?}

Como visto no primeiro Capítulo do presente trabalho, a preocupação em assegurar aos litigantes amplo acesso ao Poder Judiciário, bem como uma prestação jurisdicional sem excessiva demora é constante no processo civil contemporâneo brasileiro e de muitos outros países.

Viu-se que a possibilidade de proferir julgamento prévio de mérito da causa no momento da apreciação da petição inicial, isto é, antes mesmo da citação do réu, abreviando o iter procedimental, não é, guardadas as devidas peculiaridades, figura tão nova em nosso ordenamento, ao contrário do que se cogitou quando da introdução do art. 285-A no Código pela Lei nº 11.277/2006.

Resta-nos verificar se tal técnica, cujo propósito é abreviar a duração temporal do processo, faz-se presente também em outros ordenamentos estrangeiros. Tal questionamento, em que pese a existência de inúmeras obras versando sobre o art. 285-A do CPC, não foi respondida pela maioria dos articulistas que escreveram sobre o assunto.

\footnotetext{
${ }^{101}$ NEIVA, José Antonio Lisbôa. Improbidade administrativa: estudo sobre a demanda na ação de conhecimento e cautelar, cit., p. 99.

${ }^{102}$ GAJARDONI, Fernando da Fonseca. O princípio constitucional da tutela jurisdicional sem dilações indevidas e o julgamento antecipadíssimo da lide. In: CALDERIA, Adriano. Terceira etapa da reforma do Código de Processo Civil: estudos em homenagem ao ministro José Augusto Delgado. Salvador: JusPodivm, 2007. p. 159.
} 
Denis Donoso, em livro sobre o assunto, originário de sua dissertação de mestrado defendida perante a banca examinadora da PUC-SP, aponta a existência de dispositivos análogos ao art. 285-A do CPC nos ordenamentos da Inglaterra (rule 24.2) e de Portugal (combinação dos artigos $234^{\circ}$ e $234^{\circ}$-A do CPC português). ${ }^{103}$

A tramitação do processo comum ordinário no ordenamento português, a exemplo do que ocorre aqui no Brasil, se desenvolve por intermédio de etapas, isto é, um caminho a ser percorrido, que envolve as seguintes fases: articulados, saneamento e condensação, instrução, audiência final e de sentença final. ${ }^{104}$

A fase dos articulados refere-se à etapa em que as partes da ação (autor e réu) apresentam as peças que expõem as razões de fato e de direito que fundamentam as posições que defendem em juízo e formulam os pedidos correspondentes. O processo ordinário português admite a apresentação dos seguintes articulados: a petição inicial (art. $467^{\circ} \mathrm{CPC}$ ), a contestação (art. $486^{\circ} \mathrm{CPC}$ ), a réplica (art. $502^{\circ} \mathrm{CPC}$ ) e a tréplica (art. $503^{\circ}$ CPC), sendo possível, ainda, em alguns casos, a apresentação de articulados supervenientes, que são empregados para alegação de fatos que por desconhecimento das partes acerca de sua existência ou, ainda, por ocorrerem posteriormente, não puderam ser invocados nos articulados normais (art. 506 ${ }^{\circ} \mathrm{CPC}$ ).

A fase de saneamento ou condensação do processo apresenta dupla função. A primeira diz respeito à verificação da regularidade do processo e, sempre que possível, seu saneamento. Na segunda fase, exerce-se a chamada função de concretização que permite demarcar as questões de fato importantes para a decisão da causa. Essa etapa pode terminar com o julgamento antecipado da ação, sempre que o juiz entenda ser possível decidir a demanda ou alguns dos pedidos que amparam a pretensão do autor. ${ }^{105}$ Cabe salientar que, nos termos do art. $787^{\circ}$, quando a complexidade da causa ou a necessidade de atuar o princípio do contraditório o determinem, pode ser realizada uma audiência preliminar. ${ }^{106}$

\footnotetext{
${ }^{103}$ DONOSO, Denis. Julgamento prévio do mérito: análise do art. 285-A do CPC. São Paulo: Saraiva, 2011. p. 33-34.

${ }^{104}$ BAPTISTA, José João. Processo Civil I: parte geral e processo declarativo. 8. ed. Coimbra: Coimbra Ed., 2006. p. 366.

${ }^{105}$ COELHO, Gláucia Mara. Direito processual civil português. In: CRUZ E TUCCI, José Rogério (Coord.). Direito processual civil europeu contemporâneo. São Paulo: Lex Ed., 2010. p. 300.

${ }^{106}$ Acerca do papel da audiência preliminar naquele ordenamento, importa salientar que a mesma constitui “o momento privilegiado para que tanto o tribunal como cada uma das partes prestem o seu contributo ao avanço regular do processo, com vista a obter-se, dentro de um prazo razoável, uma justa solução para o diferendo”. (GERALDES, António Santos Abrantes. Temas da reforma do processo civil. 4. ed. rev. e atual. Coimbra: Almedina, 2004. v. 2, p. 85).
} 
Indo adiante, tem-se a fase de instrução que corresponde à fase preparatória da produção das provas. Tal fase rege-se pelo princípio da cooperação, disposto no art. $266^{\circ}$, $\mathrm{n}^{\circ} 1$, do CPC português, introduzido por intermédio das reformas de 1995-1996, que implica o dever de colaboração de todos para a descoberta da verdade, tanto nas relações das partes e de terceiros com o Tribunal, como nas relações do Tribunal com as partes, com o intuito de promover de forma célere e eficaz, a melhor composição do litígio. ${ }^{107}$

A fase de audiência final corresponde àquela em que ocorre o debate oral entre os advogados das partes a respeito das provas produzidas e o consequente julgamento da matéria de fato, bem como há uma preparação para sentença final. De acordo com o art. $656^{\circ}, \mathrm{n}^{\mathrm{o}} 2,1^{\mathrm{a}}$ parte do CPC português, a audiência final é contínua, só podendo ser descontinuada por motivos de força maior, por absoluta necessidade ou nos casos regulados na lei.

Por fim, há a fase de sentença, oportunidade em que é proferida a decisão final do procedimento em $1^{\mathrm{a}}$ instância, pondo fim à causa.

A petição inicial deve ser entregue ou enviada à secretaria judicial do Tribunal competente por correio registrado ou transmissão eletrônica de dados (atual art. $150^{\circ}$ do CPC português). Estando em termos, a ação será recebida pela Secretaria e distribuída, caso contrário, haverá recusa de recebimento ou de distribuição, a qual deve ser fundamentada por escrito, com o fito de proporcionar à parte autora a sua ocasional impugnação, por meio de reclamação para o juiz.

Conforme disciplina o art. $234^{\circ}, \mathrm{n}^{\circ}$ 1, do Código de Processo Civil português, compete à secretaria, sem dependência de despacho prévio do juiz, promover "as diligências que se mostrem adequadas à efectivação da regular citação pessoal do réu e à rápida remoção das dificuldades que obstem à realização do acto, sem prejuízo do disposto no n. 4 e da citação por agente de execução ou promovida por mandatário judicial”. 108

Da leitura de referido dispositivo verifica-se que, regra geral, dispensa-se a necessidade de intervenção liminar do magistrado determinando a citação do réu para apresentar defesa, sendo que o magistrado somente terá contato com o feito em momento

\footnotetext{
${ }^{107}$ COELHO, Gláucia Mara. Direito processual civil português, cit., p. 292-293.

${ }^{108}$ PORTUGAL. Código de Processo Civil. Disponível em: <http://www.dgpj.mj.pt/sections/leis-dajustica/livro-iii-leis-civis-e/consolidacao-processo/codigo-processocivil/downloadFile/file/CODIGO_PROCESSO_CIVIL_VF.pdf?nocache=1286970369.12>. Acesso em: 21 dez. 2012.
} 
posterior, ao término da fase dos articulados. Por clara opção do legislador, as hipótese em que a citação do réu deve ser precedida de despacho judicial, ficaram restritas àquelas descritas no art. $234^{\circ}, n^{\circ} 4$, alíneas a) a f) do CPC português. ${ }^{109}$

$\mathrm{O}$ art. $234^{\circ}-\mathrm{A}, \mathrm{n}^{\circ} 1$, do CPC português estabelece os casos em que ao magistrado é autorizado, ao invés de ordenar a citação, proferir despacho de indeferimento liminar da petição (alíneas a) a e) do n. ${ }^{\circ} 4$ do artigo $234^{\circ}$ ), com base na manifesta improcedência do pedido ou quando ocorram, de forma clara, exceções dilatórias insanáveis (por exemplo, violação de pressupostos processuais que não possam ser objeto de saneamento pela parte), acerca das quais o juiz deva conhecer de ofício.

Os casos previstos em lei para que seja liminarmente rejeitada a petição referem-se àqueles em que se constate a presença de "vícios formais ou substanciais de tal modo graves que permitem prever, logo nesta fase, que jamais o processo assim iniciado terminará com uma decisão de mérito, ou que é inequívoca a inviabilidade da pretensão apresentada pelo autor." 110

Critica-se a alteração do Código de Processo Civil português que restringiu a algumas hipóteses a intervenção liminar do juiz no feito, sob o fundamento de que aquela conduta "garantia uma melhor imagem dos tribunais na medida em que permitia obstar ao avanço de acções sem fundamento sério ou motivadas por simples objectivos de chincana processual, ou impediam o prosseguimento de acções antecipadamente votadas ao insucesso". 111

Diante do indeferimento liminar, algumas possibilidades surgem para o réu. A primeira delas é conformar-se com a decisão. Uma outra atitude refere-se à possibilidade de apresentação de recurso de agravo até à Relação, com subida nos próprios autos, independentemente do valor da ação. Tendo em vista o disposto no art. $476^{\circ}$ do $\mathrm{CPC}$ português o autor poderá, ainda, optar por entregar, no prazo de 10 dias após a notificação

\footnotetext{
${ }^{109}$ Dentre os casos em que se faz necessário despacho judicial prévio determinando a citação, temos: “ $a$ ) Nos casos especialmente previstos na lei; b) Nos procedimentos cautelares e em todos os casos em que incumba ao juiz decidir da prévia audiência do requerido; c) Nos casos em que a propositura da acção deva ser anunciada, nos termos da lei; d) Quando se trate de citar terceiros chamados a intervir em causa pendente; e) No processo executivo, nos termos do $n .^{\circ} 5$ do artigo 812. ${ }^{\circ}-E$ e do $n .^{\circ} 2$ do artigo 812. ${ }^{\circ}-F$; $f$ ) Quando se trate de citação urgente, que deva preceder a distribuição”. PORTUGAL. Código de Processo Civil. Disponível em: <http://www.dgpj.mj.pt/sections/leis-da-justica/livro-iii-leis-civis-e/consolidacaoprocesso/codigo-processocivil/downloadFile/file/CODIGO_PROCESSO_CIVIL_VF.pdf?nocache=1286970369.12>. Acesso em: 21 dez. 2012.

${ }^{110}$ Cf. GERALDES, António Santos Abrantes. Temas da reforma do processo civil, cit., p. 255.

${ }^{111}$ Cf. GERALDES, António Santos Abrantes. Temas da reforma do processo civil, cit., p. 244.
} 
do indeferimento liminar, uma nova petição inicial (articulado), corrigindo as irregularidades da primeira, desde que sejam remediáveis, ao invés de interpor o recurso, caso em que os efeitos da segunda petição retroagem ao momento da apresentação da primeira. $^{112}$

O despacho que admitir o agravo interposto contra a decisão do indeferimento liminar ordenará a citação do réu ou requerido, tanto para os termos do recurso quanto para os da causa (art. 234 ${ }^{\mathrm{a}}-\mathrm{A}, \mathrm{n}^{\mathrm{o}} 3$, do CPC português). Caso seja negado provimento ao recurso de agravo, mantendo o juiz o decidido na primeira instância, não acatando o autor tal decisão, poderá apresentar nova petição (nos termos do art. $234^{\mathrm{a}}-\mathrm{A}, \mathrm{n}^{\mathrm{o}} 1 \mathrm{c} / \mathrm{c}$ art. $476^{\circ}$ ). Caso contrário, revogando-se os termos do despacho de indeferimento, seguirá o feito seu trâmite normal, com a notificação do réu, anteriormente já citado, para apresentação de contestação (art. art. 234 ${ }^{\mathrm{a}}$-A, no 4 , do CPC português).

Em síntese, o processo de conhecimento ordinário no sistema processual português é composto de cinco fases que não são estanques, ocorrendo no mais das vezes de forma interligada, sendo que podem surgir situações diversas que determinem a abreviação do procedimento, com supressão de algumas das etapas acima mencionadas.

Diferentemente do que ocorre no Brasil, a citação do réu, regra geral, não dependente de despacho judicial, competindo à secretaria promovê-la sem necessidade de despacho prévio (de acordo com o art. $234^{\circ}$, que traz a regra da oficiosidade das diligências destinadas à citação). Os casos em que se faz necessária a intervenção do juiz antes da citação do réu estão restritos àqueles elencados em lei. Em tais hipóteses, como já salientado, pode o magistrado, em sendo o caso, indeferir liminarmente a petição ao invés de ordenar a citação do réu, pondo fim, desde logo, à ação.

Ao que nos interessa no presente estudo, por pedido manifestamente improcedente há de se entender aquele que não procede qualquer que seja a interpretação que lhe seja dada, não havendo possibilidade de seu acolhimento pelos tribunais, seja porque a lei não o comporta ou porque as ocorrências apuradas, face ao direito, não o justificam. ${ }^{113}$

\footnotetext{
${ }^{112}$ Cf. BAPTISTA, José João. Processo Civil I: parte geral e processo declarativo, cit., p. 378.

${ }^{113}$ Nesse sentido, apreciando o significado da expressão manifestamente improcedente, numa tentativa de preencher este conceito indeterminado, a jurisprudência daquele país sumarizou a seguinte conclusão: "I A improcedência é manifesta quando, à vista da petição e dos factos alegados, for evidente que a tese do autor não tem condições para vingar nos tribunais, seja por carecer de suficiente apoio legal ou por não ter quem a defenda na jurisprudência ou na doutrina. II- O pedido será manifestamente improcedente quando for evidente que, pelos fundamentos apresentados (causa de pedir) o demandante não tem o direito a que se arroga. III-Tem, por isso, de ser ostensiva, de uma evidência irrecusável, a falta de fundamento
} 
Dito doutro modo, o julgamento prévio do mérito da causa só deve ocorrer quando a improcedência da pretensão da parte autora se mostre de maneira tão evidente que torne baldio qualquer instrução e discussão posteriores, tornando inútil a continuação do processo, levando a um desperdício evidente da atividade judicial. ${ }^{114}$

Diante de todo o exposto, temos que a regra que possibilita ao juiz proferir despacho de indeferimento liminar no direito processual português aproxima-se, mas como se verá no decorrer do presente trabalho, não se assemelha totalmente à proposta do art. 285-A de nosso Código de Processo Civil. Isto porque, ressalvado o fato de que ambos permitem o julgamento da demanda em momento limiar, com eliminação de algumas das fases do processo, os pressupostos para sua aplicação não se confundem. Outra diferença, adiantamos, refere-se aos desdobramentos que surgem com a prolação de tal julgamento.

No que diz respeito ao direito processual civil da Inglaterra e do País de Gales, temos que até o ano de 1.999, duas eram as principais fontes legislativas, quais sejam, as Regras da Suprema Corte, de 1981, (RSC - Rules of the Supreme Court), que lidavam com questões referentes à High Court e à Court of Appel e as CCR (County Court Rules), que dispunham sobre o andamento processual perante os órgãos judiciários inferiores. ${ }^{115}$

Contudo, o panorama alterou-se com as Civil Procedure Rules (CPR), vigentes a partir de abril de 1999, que apresentaram-se como o primeiro código de processo civil daquele ordenamento, surpreendendo pela presença de detalhes e inovações, dentre elas o poder de gestão dos processos atribuído aos tribunais. Acompanhando as CPR, foram disponibilizadas diretivas práticas (practice directions) pelos diversos órgãos judiciários, isto é, diretrizes para esclarecer a aplicação das novas regras.

A estrutura judiciária do direito inglês é composta dos seguintes órgãos: Appellate Committee of the House of Lords, que passou a ser chamada Supreme Court of the United Kingdom, por força do ato de reforma constitucional de 2005, e é responsável pelo julgamento, em último grau, dos recursos; logo abaixo, temos a High Court of Justice e a

jurídico da pretensão apresentada pelo demandante." (ACÓRDÃO do Tribunal da Relação do Porto, de 01.06.2010, $\quad$ 5roc. 5735/09.0TBMTS.P1. Disponível em: <http://www.dgsi.pt/jtrp.nsf/c3fb530030ea1c61802568d9005cd5bb/c5455dc1bef95d64802577880036f885 ?OpenDocument\&Highlight=0,5735\%2F09.0TBMTS>. Acesso em: 23 dez. 2012).

${ }^{114}$ Cf. GERALDES, António Santos Abrantes. Temas da reforma do processo civil. 2. ed. rev. e atual. Coimbra: Almedina, 2006. v. 1, p. 258-259.

${ }^{115}$ Cf. CRUZ E TUCCI, José Rogério. Direito processual civil inglês. In: CRUZ E TUCCI, José Rogério (Coord.). Direito processual civil europeu contemporâneo. São Paulo: Lex Ed., 2010. p. 216-217. 
Court of Appeal, que compõem a Supreme Court of Judicature; e, por fim, as County Courts, responsáveis pelo julgamento das causas em primeiro grau. ${ }^{116}$

Importa salientar que o direito inglês possui uma fase pré-processual, na qual os litigantes devem observar os protocolos (pre-action protocols) como forma de preparação do caso e, acima de tudo, como tentativa de solução da controvérsia de forma consensual, sem que seja necessário o ajuizamento da demanda. Tal etapa demanda um espírito de cooperação entre as partes, sendo que somente após percorrido todas as obrigações previstas em lei e caso reste infrutífera a tentativa de acordo é que o caso será encaminhado ao Judiciário. ${ }^{117}$

O ajuizamento de uma demanda, por meio de petição inicial, é feito através do preenchimento de um formulário uniformizado que deve conter um resumo do pedido, a natureza da tutela requerida e o valor a ser atribuído à causa. As CPR estabelecem três espécies de procedimento comum (tracks), de acordo com a natureza, características dos conflitos e, principalmente, valor do objeto do litígio, quais sejam: o small claims track, fast track e o multi-track. O small claims track é voltado para as demandas cujo valor envolvido não ultrapasse a quantia de $£ 5,000$ (cinco mil libras esterlinas). As causas entre $£ 5,000$ (cinco mil libras esterlinas) e $£ 25,000$ (vinte e cinco mil libras esterlinas) devem seguir o fast track, sendo o multi-track aplicável para os casos mais complexos e que envolvam valores superiores a $£ 25,000$ (vinte e cinco mil libras esterlinas). ${ }^{118}$

O caminho a ser seguido em cada caso é decidido pelo juiz com base no valor e complexidade do litígio. Tal escolha é feita levando em consideração, sempre que possível, as informações fornecidas pelas partes em um formulário denominado allocation questionnaire. Em tal formulário as partes são indagadas se possuem interesse em acordo, se fizeram uso do devido pre-action protocol, informam quais os esforços já foram realizados na tentativa de celebração de um acordo, qual o procedimento consideram mais adequado, informam os valores envolvidos, as testemunhas a serem ouvidas (se for o caso), a necessidade de perícia e sugerem peritos, apresentam uma estimativa de tempo para o

\footnotetext{
${ }^{116}$ Cf. CRUZ E TUCCI, José Rogério. Direito processual civil inglês, cit., p. 218-219.

${ }^{117}$ ANDREWS, Neil. $O$ moderno processo civil: formas judiciais e alternativas de resolução de conflitos na Inglaterra. Orientação e revisão da tradução Teresa Arruda Alvim Wambier. São Paulo: Ed. Revista dos Tribunais, 2009. p. 29.

${ }^{118} \mathrm{HM}$ COURTS \& TRIBUNALS SERVICE. The small claims track in civil courts. Disponível em: <http://hmctsformfinder.justice.gov.uk/courtfinder/forms/ex306-eng.pdf>. Acesso em: 23 dez. 2012.
} 
julgamento, propõem direcionamentos que podem ser dados à causa, estimam as custas do processo e fornecem quaisquer outras informações necessárias. ${ }^{119}$

Recebida a petição inicial, o réu deve ser cientificado da demanda, podendo optar por reconhecer o pedido, solicitar prazo para defesa ou, então, defender-se, iniciando o procedimento perante o Tribunal, oportunidade em que o caso será alocado em um dos três procedimentos acima mencionados. ${ }^{120}$

Ultrapassada a fase pré-litígio e iniciado o processo formal perante um Tribunal, obtendo o autor formulário de petição com data definida, deverá o processo observar determinadas fases de desenvolvimento, que envolvem a fase postulatória, a etapa de preparação das provas, que abrange a verificação da necessidade de prova pericial e divulgação de documentos antes do julgamento (disclosure), a audiência de instrução e julgamento, a etapa de recursos e a de execução, desde que haja requerimento da parte vitoriosa nesse sentido. $^{121}$

Caso no decorrer do processo as partes não celebrem algum tipo de acordo, este se finda, regra geral, pela realização do trial. A audiência pode vir a ser dispensada pelo juiz quando este entender que o caso pode ser julgado somente com base na prova escrita já apresentada. O juiz pode optar, ainda, por proferir a sentença ao final da sessão do trial ou em data posterior. Admite-se recurso contra a decisão do juiz, sendo necessário, contudo, sua prévia permissão para fazê-lo, bem como argumentos apropriados. ${ }^{122}$

Registre-se que as CPR oferecem a possibilidade de julgamentos sumários que permitem ao juiz pôr fim ao procedimento ainda que não percorridas todas as etapas.

A primeira hipótese a ser mencionada refere-se ao default judgment (regra 12.1) que é aquele julgamento que ocorre sem a necessidade de realização de audiência quando, devidamente citado, o réu deixe de apresentar defesa ou, ainda, protocolizar um

\footnotetext{
${ }^{119}$ ALMEIDA, Diogo Assumpção Rezende de. O Case Management inglês: um sistema maduro? Revista Eletrônica de Direito Processual - REDP, São Paulo, v. 2, p. 287-335. Disponível em: $<\mathrm{http}$ ///www.redp.com.br/arquivos/redp_7a_edicao.pdf>. Acesso em: 23 dez. 2012.

${ }^{120}$ De acordo com Paulo Eduardo Alves da Silva: "A indisponibilidade do procedimento no sistema inglês é parcial. Não havendo vedação legal, juiz e partes podem dispor sobre o procedimento, inclusive prazos $e$ ritos, desde que atendidos os overriding objectives estabelecidos em lei. Vários dispositivos do código estabelecem esta permissão. O juiz pode, por exemplo, escolher, substituir ou mesclar procedimentos, separar as questões para processamento ou julgamento em separado, deixar de apreciar a questão impertinente (Rule 3.1(2)). Pode, inclusive, fixar, abreviar ou estender os prazos". (SILVA, Paulo Eduardo Alves da. Gerenciamento de processos, cit., p. 45).

${ }^{121}$ ANDREWS, Neil. O moderno processo civil: formas judiciais e alternativas de resolução de conflitos na Inglaterra, cit., p. 52-53.

${ }^{122}$ Cf. CRUZ E TUCCI, José Rogério. Direito processual civil inglês, cit., p. 237.
} 
reconhecimento de citação (acknowledgment of service), com pedido de prorrogação de prazo para defesa. No caso do julgamento à revelia, o magistrado "julgará o mérito, com base nas alegações veiculadas pelo autor e no material probatório por ele apresentado". 123

Outra forma de julgamento que dispensa a realização de audiência diz respeito àquele proferido nos termos da regra 3.5, após o afastamento da pretensão do autor ou defesa do réu (striking out) previsto na regra 3.4 das $\mathrm{CPR}^{124}$. A parte contra quem foi proferido o referido julgamento pode, de acordo com a regra 3.6, requerer a sua revogação perante o mesmo órgão judicial que o exarou.

É possível, finalmente, que o procedimento não atinja a fase instrutória quando, a teor do que dispõe a regra 24.2, ocorra o chamado julgamento sumário (summary judgment). O juiz pode abreviar o procedimento, afastando ou acolhendo o pedido do autor, de ofício ou a requerimento de qualquer das partes. Para que seja apreciado o requerimento efetuado pelo autor, é necessário que se aguarde a apresentação de defesa ou protocolo de reconhecimento de citação pelo réu. O réu pode requerer o julgamento sumário a qualquer tempo após o ajuizamento da demanda pelo autor.

As hipóteses de cabimento para sua aplicação são: a) que demandante ou demandado não possuam real perspectiva de sucesso no pedido ou defesa, respectivamente; b) que não haja qualquer motivo para que o caso prossiga até julgamento na sua forma mais solene (trial).

O intuito do instituto é agilizar o procedimento, evitando atrasos e despesas, não admitindo o prosseguimento em direção ao trial de um processo cujo pedido ou defesa apresente-se manifestamente improcedente, isto é, sem chances de êxito. Busca-se, com isso, julgar antecipadamente procedente o pedido do autor ou rejeitá-lo de imediato, dependendo de quem fez o requerimento, com base nas provas documentais apresentadas.

\footnotetext{
${ }^{123}$ ALMEIDA, Diogo Assumpção Rezende de. O Case Management inglês: um sistema maduro?, cit., p. 287335.

124 "The court may strike out a statement of case if it appears to the court - (a) that the statement of case discloses no reasonable grounds for bringing or defending the claim; (b) that the statement of case is an abuse of the court's process or is otherwise likely to obstruct the just disposal of the proceedings; or (c) that there has been a failure to comply with a rule, practice direction or court order". Em tradução livre: $\mathrm{O}$ tribunal pode desconsiderar as assertivas das partes se lhe parecer que - (a) a pretensão ou a defesa não se baseiam em argumentos razoáveis; (b) a pretensão ou a defesa representam um abuso de processo perante a corte ou provavelmente obstruirão o desenrolar legítimo do procedimento; (c) alguma das partes deixou de atender a regra, prática diretiva ou determinação expressa do tribunal.
} 
A Corte possui as seguintes opções em uma audiência no procedimento sumário: (a) acolher o requerimento da parte que solicitou o julgamento antecipado, julgando o mérito, de forma total ou parcial; (b) não acatar a solicitação, prosseguindo o processo na direção do trial, quando então haverá o julgamento da causa; (c) conceder uma ordem condicional (conditional order), afirmando que, ainda que improvável, a pretensão ou a defesa contestada pode ter êxito, exigindo a prestação de caução em dinheiro ou outra providência para que o feito prossiga até o julgamento. ${ }^{125}$

O julgamento sumário e a rejeição de ação ou defesa são espécies de julgamento antecipado concebidos para evitar que casos perdurem por longos períodos à espera da audiência de instrução e julgamento. Diferenciam-se, contudo, porque o julgamento sumário comporta uma investigação um pouco mais aprofundada dos pontos relevantes e provas apresentadas. Ademais, outra diferença refere-se ao recurso cabível em face de tais julgamentos, sendo que no caso do julgamento sumário somente é possível a utilização de um recurso para um tribunal hierarquicamente superior.

O julgamento sumário, extraído da regra 24.2 das CPR, ao que nos parece, se harmoniza mais com o julgamento conforme o estado do processo, proferido antes da fase instrutória, na forma de julgamento antecipado da lide, previsto no art. 330, inc. I, do CPC brasileiro, do que com o art. 285-A do CPC. Tal conclusão se justifica tendo em vista que o julgamento antecipado da lide é também sentença com julgamento de mérito, acolhendo ou rejeitando o pedido do autor, desde que envolva matéria unicamente de direito ou, sendo de direito e de fato, não demande a produção de prova em audiência.

Nos Estados Unidos, o código de processo civil federal (federal rules of civil procedure), possui regramento que também permite um julgamento sumário, que dispensa que o processo se desenvolva até o julgamento (trial). De acordo com a regra $56^{126}$, o pedido de julgamento sumário pode ser apresentado por ambas as parte, e tem por finalidade eliminar atrasos e gastos com a realização de uma audiência de instrução. Para tanto, o requerente do pedido de julgamento sumário deve demonstrar que os fatos não são realmente como a parte contrária pretende mostrá-los e que por tal motivo possui direito a este julgamento antecipado.

\footnotetext{
${ }^{125}$ ANDREWS, Neil. O moderno processo civil: formas judiciais e alternativas de resolução de conflitos na Inglaterra, cit., p. 117-118.

${ }^{126}$ FEDERAL Rules of Civil Procedure With Forms, as amended to December 1, 2010. U.S. Government Printing Office - $\quad$ Washington: 2010.2 Disponível em: $<$ http://www.uscourts.gov/uscourts/RulesAndPolicies/rules/2010\%20Rules/Civil\%20Procedure.pdf>. Acesso em: 24 de dez. 2012.
} 
Tal instituto se assemelha com o julgamento sumário inglês. A decisão que põe fim ao processo em primeira instância, caso não haja recurso no prazo legal, estará sujeita aos efeitos da coisa julgada. ${ }^{127}$

Antes de ajuizar uma demanda civil, devem as partes verificar se realmente existe um caso, um litígio. Isso porque, se ajuizar uma ação que seja considerada fútil (frivolous claim), isto é, que tenha por intuito causar embaraços à outra parte ou que não tenha fundamento, a parte poderá ser penalizada com multa, pagamento de custas judiciais e outros gastos que tenha incorrido a parte adversa, bem como outros tipos de sanções. Assim, deve a parte verificar se há suporte legal para seu pedido.

Feitas essas considerações e diante das pesquisas por nós desenvolvidas, não encontramos notícia de instituto idêntico ao art. 285-A do CPC em outros ordenamentos estrangeiros, o que nos leva a concluir que, pode sim, ser o mesmo considerado um instrumento fundamentalmente tupiniquim.

\subsection{Artigo 285-A do CPC: faculdade ou dever?}

A doutrina diverge sobre o caráter obrigacional ou permissivo da norma, isto é, se o julgamento de improcedência, dispensada a citação, seria um dever ou uma prerrogativa do magistrado.

Há autores que entendem que a norma em comento deve ser entendida como uma faculdade legal conferida ao magistrado, a ser aplicada conforme sua convicção e que sempre poderá ser revista, não se constituindo, pois, em obrigação ou dever.

No que diz respeito à discricionariedade do magistrado na utilização da técnica em comento, defende-se não haver imperatividade na aplicação da norma em questão, por tratar-se de "simples faculdade ao juiz, não estando ele obrigatoriamente sujeito a decidir de plano, nem nula será qualquer decisão ulterior, se o réu, por exemplo, provar, em recurso, sentença semelhante do mesmo juízo". ${ }^{28}$

\footnotetext{
${ }^{127}$ GODOY, Arnaldo Sampaio de Moraes. Processo civil dos EUA buscou excepcionalismo. Revista Consultor Jurídico, 16 mar. 2011. Disponível em: <http://www.conjur.com.br/2011-mar-16/tudo-euaconstrucao-processo-civil-buscou-excepcionalismo?pagina=4>. Acesso em: 23 dez. 2012.

${ }^{128}$ SANTOS, Ernane Fidélis dos. As Reformas de 2005 e 2006 do Código de Processo Civil. 2. ed. São Paulo: Saraiva, 2006. p. 148. Também nesse sentido, PINTO, Fernanda Guedes. As ações repetitivas e o novel art. 285-A do CPC (racionalização para as demandas de massa), cit., p. 128.
} 
A técnica prevista no art. 285-A do CPC, nesse sentido, não implicaria qualquer obrigatoriedade ao juiz, que se entender mais prudente, mesmo ciente da existência, no juízo, de julgado de total improcedência em casos similares, poderá determinar a citação e processar normalmente a causa, quando verificar que esta apresenta alguma peculiaridade ou, ainda, quando tenha mudado seu posicionamento. ${ }^{129}$

Contudo, tal entendimento não é unânime. Isto porque há autores que entendem que para o juiz não há liberdade de escolha acerca dos casos em que o dispositivo poderá ou não ser utilizado, uma vez que para estes há verdadeiro poder-dever. ${ }^{130}$ Assim, preenchendo o processo em exame os requisitos necessários previstos em lei, outra saída não terá o magistrado senão fazer uso do artigo e julgar, sem necessidade de citação, improcedente o mérito da demanda.

Segundo esta linha de pensamento, o artigo 285-A do CPC alberga verdadeira hipótese de dever do magistrado, sendo que a determinação de prosseguimento do feito, com a citação do demandado, em caso de incidência das hipóteses do dispositivo, consistiria em verdadeiro descumprimento de um dever legal.

Entendemos, contudo, que a primeira corrente, a que defende que a aplicação do art. 285-A do CPC seja uma faculdade do magistrado, é a que melhor se coaduna com o espírito da lei. Assim, não nos parece que a norma contida no caput do art. 285-A, seja verdadeiramente um dever imposto ao magistrado para que se sinta obrigado a julgar antecipadamente o objeto do processo, antes mesmo de determinar a realização da citação da parte contrária.

Com efeito, o legislador teve a preocupação de utilizar o verbo poder, ao invés do verbo dever, deixando ao arbítrio do próprio juiz a escolha entre julgar de imediato a causa ou aguardar o desenvolvimento do processo, naqueles casos em que não se sentir seguro para se utilizar do atalho procedimental instituído pela lei. ${ }^{131}$

\footnotetext{
${ }^{129}$ ALVIM, Eduardo Arruda. Do julgamento de improcedência de casos repetitivos, à luz da lei $\mathrm{n}^{\circ}$ 11.277/2006 - algumas reflexões atinentes ao art. 285-A do CPC. Revista Forense, Rio de Janeiro, v. 103, n. 393, p. 44, set./out. 2007.

${ }^{130}$ Nesse sentido: ARAÚJO, Luciano Vianna. 285-A do CPC (julgamento imediato, antecipado e maduro da lide): evolução do sistema desde o Código de Processo Civil de 1939 até 2007, cit., p. 174 e CIMARDI, Cláudia A. Notas sobre o art. 285-A do CPC (sentença liminar de improcedência). In: MEDINA, José Miguel Garcia et al (Coord.). Os poderes do juiz e o controle das decisões judiciais: estudos em homenagem à Professora Teresa Arruda Alvim Wambier. São Paulo: Ed. Revista dos Tribunais, 2008. p. 410.

${ }^{131} \mathrm{Na}$ mesma esteira, confira-se: "AGRAVO LEGAL. REVISÃO. FATOR PREVIDENCIÁRIO. ART. 285-A DO CPC. TÁBUA COMPLETA DE MORTALIDADE. CÁLCULO DA RENDA MENSAL INICIAL. DECISÃO DO STF NA ADIN-MC 2111-DF.- Discussão a respeito da aplicação do fator previdenciário no cálculo da renda mensal inicial de benefício, a significar a predominância de questão de direito sobre
} 
A corroborar tal entendimento, convém salientar que acaso configurasse a norma em testilha uma espécie de dever, não haveria razão para não se impor alguma espécie de sanção pelo seu descumprimento. Fato é que não há na lei qualquer menção a algum tipo de medida repressiva, tampouco caberá qualquer tipo de recurso em face do ato judicial que receber a inicial, ordenando a citação do réu.

Assim, e ainda em respeito à independência funcional dos juízes, o artigo em comento não traz um dever legal mas sim uma faculdade, competindo exclusivamente ao magistrado decidir os casos em que o julgamento prévio de improcedência seja viável. Além do mais, ao juiz, a quem caberá aferir se há nos autos subsídios e provas suficientes para formar sua convicção, deve ser sempre permitido alterar seu posicionamento, mesmo que esteja diante de caso análogo a outros por ele já julgados improcedentes anteriormente. Deve o juiz, contudo, manter coesão em seus julgados, sendo que preenchidos os requisitos, somente deverá postergar a prestação da tutela jurisdicional, praticando atos considerados desnecessários (tais como a citação, prazo para resposta, réplica etc.), se existirem motivos relevantes para tanto.

\subsection{Requisitos para aplicação do Art. 285-A do CPC}

O artigo 285-A do CPC, em que pese algumas impropriedades técnicas, traz em seu texto requisitos ainda mais rígidos do que aqueles elencados pelo inciso I do art. 330 do CPC para a antecipação do julgamento, os quais devem ser respeitados a fim de se afastar eventuais arguições de nulidade processual.

Do que se depreende da leitura de referido preceito legal é forçoso, para a aplicação do art. 285-A, que se façam presentes os seguintes requisitos: a) matéria controvertida unicamente de direito; b) existência de causas idênticas precedentes; e c) possibilidade de 
se decidir o processo a partir da reprodução de sentenças de improcedência anteriormente proferidas pelo juízo.

\subsubsection{Matéria controvertida unicamente de direito}

Inicialmente, convém destacar a impropriedade do termo "matéria controvertida" como requisito para a prolação de julgamento nos termos do art. 285-A. Isto porque o julgamento prévio do mérito é proferido sem que tenha ocorrido a citação do réu e, por conseguinte, sem a apresentação de defesa impugnando os pontos (de fato e de direito) alegados pelo autor, o que torna mais apropriada a supressão do adjetivo controvertida quando da interpretação do dispositivo. ${ }^{132}$

De qualquer forma, por matéria controvertida unicamente de direito, expressão contida na redação do artigo, deve-se entender aqueles casos que não demandem, a princípio, debate a respeito de aspectos fáticos e sim apenas de aspectos normativos. Ainda, como esclarecem Nelson Nery Jr. e Rosa M. A. Nery, onde lê-se 'matéria controvertida' deve-se interpretar como aquela alegação que já tenha sido objeto de controvérsia em outros processos anteriores e julgada improcedente pelo mesmo juízo. ${ }^{133}$

O primeiro requisito apontado pela norma, assim, requer para sua aplicação, que a demanda não dependa de dilação probatória ou esclarecimento de fato para o exame do mérito. Nessa toada, para permitir esse julgamento mais do que antecipado, o desenlace da causa deve estar sujeito unicamente à subsunção dos fatos narrados pelo autor a uma norma ou tese jurídica.

Fernando da Fonseca Gajardoni destaca a necessidade de se fazer uma interpretação ampliativa do instituto, a fim de que não se restrinja a utilização do art. 285-A às questões unicamente de direito. Para referido autor, poderá ser proferido julgamento de improcedência prima facie, ainda que o caso demande a apreciação de matéria fática,

\footnotetext{
${ }^{132}$ Atentando para essa atecnia na redação do dispositivo: CUNHA, Leonardo José Carneiro da. Primeiras impressões sobre o art. 285-A do CPC (julgamento imediato de processos repetitivos: uma racionalização para as demandas de massa). Revista Dialética de Direito Processual, n. 39 jun. p. 95, 2006.

${ }^{133}$ NERY JÚNIOR, Nelson; NERY, Rosa Maria Andrade. Código de Processo Civil comentado e legislação processual civil extravagante em vigor, cit., p. 580.
} 
desde que os elementos trazidos na inicial ou previamente colhidos revelem, na esteira de casos similares do juízo, a improcedência do pedido. ${ }^{134}$

Temos, assim, que inexistem questões unicamente de direito, mas, sim, questões predominantemente de direito ${ }^{135}$, relacionadas às hipóteses que envolvam questões de fato e de direito, mas que o juiz entende desnecessária a produção de prova pericial e/ou oral para o julgamento do pedido do autor, sendo suficiente a prova documental constante dos autos. $^{136}$

Assemelha-se tal expressão, por conseguinte, àquela da segunda parte do inciso I do art. 330 do CPC, ou seja, "sendo de direito e de fato, não houver necessidade de prova em audiência", contudo, neste último caso, para que possa o magistrado conhecer diretamente do pedido, de rigor que se viabilize previamente o contraditório, o que não ocorre no caso do julgamento prima facie do mérito.

Outra diferença entre esses institutos que merece ser destacada, sendo essencial para melhor compreensão do art. 285-A do CPC, é que neste deve prevalecer a tese jurídica sobre a questão de fato, que não possui, regra geral, nenhuma peculiaridade, por ser semelhante àquelas que foram objeto de causas repetitivas anteriores, não comportando, por isso, maiores indagações quanto à sua existência e seus limites. A dúvida que surge diz respeito tão somente em saber qual o direito aplicável sobre aqueles fatos que já foram motivo de controvérsia anterior. ${ }^{137}$

Isso nos leva a concluir que o art. 285-A é nova hipótese de julgamento conforme o estado do processo, uma vez que se refere a julgamento da causa pelo juiz no momento em que só prova documental foi produzida e antes da audiência de instrução e julgamento.

\footnotetext{
${ }^{134}$ GAJARDONI, Fernando da Fonseca. O princípio constitucional da tutela jurisdicional sem dilações indevidas e o julgamento antecipadíssimo da lide, cit., p. 160-161.

${ }^{135}$ Acerca da existência de determinados graus de predominância do aspecto jurídico sobre o fático, confirase: "No plano ontológico, devem-se admitir (tanto quanto no plano técnico-processual) graus de predominância do aspecto jurídico da questão. Ter-se-á, por exemplo, uma questão quase que exclusivamente jurídica, se o foco do raciocínio do juiz estiver situado em como deve ser entendido o texto normativo, já que estariam 'resolvidos' os aspectos fáticos (= que fatos ocorreram e como ocorreram) e o mecanismo da subsunção. Estas primeiras etapas do raciocínio do aplicador da lei terão sido superadas e, agora, sua atenção se centra na exata compreensão do mandamento legal" (WAMBIER, Teresa Arruda Alvim. Questões de fato, conceito vago e a sua controlabilidade através de recurso especial. In: WAMBIER, Teresa Arruda Alvim. Aspectos polêmicos e atuais do recurso especial e do recurso extraordinário. São Paulo: Ed. Revista dos Tribunais, 1997. p. 449-450).

${ }^{136}$ CAVALCANTE, Mantovanni Colares. A sentença liminar de mérito do art. 285-A do Código de Processo Civil e suas restrições. Revista Dialética de Direito Processual, São Paulo, n. 42, p. 100, set. 2006.

${ }^{137}$ BUENO, Cássio Scarpinella. A nova etapa do Código de Processo Civil: comentários sistemáticos às Leis n. 11.276 de 7-2-2006, 11.277, de 7-2-2006, e 11.280, de 16-2-2006. São Paulo: Saraiva, 2006. v. 2, p. 75.
} 
Outro ponto a ser destacado, até mesmo diante da finalidade do instituto e da sua natureza excepcional, é que se a pretensão abordar questões predominantemente de fato e que demandem produção de prova, o juiz não estará autorizado a empregar o dispositivo em comento e antecipar o julgamento, devendo, ao contrário, decidir pelo prosseguimento regular da causa.

O projeto de criação do novo Código de Processo Civil (Projeto de Lei 8.046/2010), que tramita atualmente na Câmara dos Deputados, vem sendo acompanhado de forma atenta pelos estudiosos e operadores do direito. Referido projeto, cabe salientar, é originado do Senado Federal (Projeto de Lei do Senado n. ${ }^{\circ} 166$, de 2010), que nomeou e confiou a redação inicial do projeto de novo CPC a uma comissão de juristas, presidida pelo Ministro Luiz Fux.

No que diz respeito à questão do julgamento de improcedência prima facie, o conteúdo do art. 285-A do atual CPC foi realocado, originariamente, para o art. 317, sob a designação de "Da rejeição liminar da demanda". Na redação constante do PL 8.046/2010, foi atribuída nova redação à norma, agora contida no art. 307, Capítulo III (denominado "Da improcedência liminar do pedido"), Título I (Do Procedimento Comum), Livro II (Processo de Conhecimento e Cumprimento de Sentença), nos seguintes termos:

Art. 307. O juiz julgará liminarmente improcedente o pedido que se fundamente em matéria exclusivamente de direito, independentemente da citação do réu, se este:

I - contrariar súmula do Supremo Tribunal Federal ou do Superior Tribunal de Justiça;

II - contrariar acórdão proferido pelo Supremo Tribunal Federal ou pelo Superior Tribunal de Justiça em julgamento de recursos repetitivos;

III - contrariar entendimento firmado em incidente de resolução de demandas repetitivas ou de assunção de competência.

$\S 1^{\circ} \mathrm{O}$ juiz também poderá julgar liminarmente improcedente o pedido se verificar, desde logo, a ocorrência a decadência ou a prescrição.

$\S 2^{\circ}$ Não interposta a apelação, o réu será intimado do trânsito em julgado da sentença.

$\S 3^{\circ}$ Aplica-se a este artigo, no que couber, o disposto no art. 306.

Verifica-se da leitura de referido dispositivo que apesar das críticas acima explicitadas e de um trocadilho de palavras (alteração da redação de "unicamente de direito" para "exclusivamente de direito"), caminha o projeto mantendo a exigência verificada neste item no sentido de que a matéria apta a ensejar o julgamento de 
improcedência prima facie deve dispensar a necessidade de dilação probatória, isto é, produção de prova em audiência, bastando aquela já trazida aos autos com a inicial.

\subsubsection{Existência de casos idênticos}

A identidade entre demandas, na esfera processual, é definida pela verificação da presença de três elementos: mesmas partes, pedido e causa de pedir. Assim, configurada a tríplice identidade, estar-se-á diante de ações idênticas. Não é esta, contudo, a ideia que se extrai do disposto no art. 285-A do CPC. Senão vejamos.

Em toda demanda é afirmado pelo demandante a existência de uma relação jurídica. A "Res In Iudicium Deducta" é a relação deduzida em juízo, aquilo que será discutido, sendo posto pelo demandante.

São elementos da relação jurídica as partes, o objeto e o fato. Como em toda demanda se afirma ao menos uma relação jurídica, e esta tem partes, objeto e fato, logo, toda demanda envolve sujeitos, sobre um objeto, por conta de um fato. Assim, os elementos da demanda são três, partes, pedido e causa de pedir, relacionando-se, assim, com os elementos da relação jurídica. ${ }^{138}$

São partes, em sentido técnico, o autor (ou autores) e o réu (ou réus), que figuram na demanda. $\mathrm{O}$ autor é aquele que pede a prestação jurisdicional, enquanto o réu é aquele em face de quem se pede. ${ }^{139}$ Saliente-se que o Ministério Público pode ser parte em uma

\footnotetext{
${ }^{138}$ Ensina Cândido Rangel Dinamarco que "embora seja correto falar em condições da ação, como requisito sem os quais não há o direito ao provimento a ser emitido pelo juiz (sentença de mérito), é preferível falar em elementos constitutivos da demanda, não da ação. São eles os fatores que, em cada demanda concretamente considerada, dão-lhe individualidade própria e a distinguem das demais (daí, identificadores segundo a linguagem mais comum na doutrina); esses fatores são as partes, a causa de pedir e o pedido." (DINAMARCO, Cândido Rangel. Instituições de direito processual civil. 6. ed. São Paulo: Malheiros Ed., 2009. v. 1, p. 307).

139 “Partes - São as pessoas que participam do contraditório perante o Estado-juiz. É aquele que, por si próprio ou através de representante, vem deduzir uma pretensão à tutela jurisdicional, formulando pedido (autor), bem como aquele que se vê envolvido pelo pedido feito (réu), de maneira que uma sua situação jurídica será objeto de apreciação judiciária. A qualidade de parte implica sujeição à autoridade do juiz e a titularidade de todas as situações jurídicas que caracterizam a relação processual." (CINTRA, Antônio Carlos de Araújo; DINAMARCO, Cândido Rangel; GRINOVER, Ada Pellegrini. Teoria geral do processo, cit., p. 284).
} 
ação ${ }^{140}$ ou ser chamado a intervir ao menos como custos legis na causa (assunto que será discutido no item 2.8).

A causa de pedir, por sua vez, é constituída pelos fatos e pelos fundamentos jurídicos do pedido. ${ }^{141}$ Nesse sentido, os fatos que deram origem ao pedido devem ser expostos ao magistrado, bem como as consequencias jurídicas que podem ser extraídas desses fatos, com o fim de gerar segurança nessas relações jurídicas em litígio.

A causa de pedir subdivide-se em causa de pedir remota, que abarca os fatos narrados pela parte autora como ensejadores de seu direito e a causa de pedir próxima, composta pelos fundamentos jurídicos. Predomina em nosso ordenamento, a teor do que dispõe o art. 282, III, do CPC, a teoria da substanciação da causa de pedir, que considera como elemento identificador da ação não apenas a causa de pedir próxima, mas também a causa de pedir remota.

Indo adiante, entende-se como pedido aquela providência que a parte autora quer obter do Poder Judiciário, ante a oposição do réu em conceder-lhe. Distingue-se o pedido em mediato e imediato. O primeiro, pedido mediato, é o bem da vida que se quer obter na relação jurídica levada ao Judiciário, vinculado ao direito material, enquanto por pedido imediato considera-se o provimento jurisdicional que se espera. A guisa de exemplo, numa ação de cobrança, o pedido mediato refere-se à quantia monetária que se quer receber, já o pedido imediato configura-se na providência jurisdicional solicitada, qual seja, a condenação do requerido ao pagamento do numerário devido.

Apesar de o dispositivo legal fazer referência a casos idênticos, aponta-se a impropriedade terminológica, uma vez que não quer ele dizer ações idênticas, nos termos do art. 301, $\S 2^{\circ}$, do Código de Processo Civil, ou seja, mesmas partes, causa de pedir e pedido, uma vez que, fosse esta a hipótese, o processo deveria ser extinto por ofensa à

\footnotetext{
${ }^{140}$ Tal como foi bem destacado por Carlos Alberto de Salles, “a atuação do Ministério Público no processo é sempre precedida de um questionamento sobre sua legitimidade, o que, de maneira geral, significa perquirir sobre a existência de algum interesse público qualificado na situação de direito material." (SALlES, Carlos Alberto de. A legitimação do Ministério Público para defesa de direitos e garantias constitucionais. 1992. Dissertação (Mestrado) - Faculdade de Direito, Universidade de São Paulo. São Paulo, 1992. p. 113).

${ }^{141}$ É de se destacar que tal entendimento não é unânime, havendo aqueles que sustentam que a causa de pedir seria tão somente constituída pela narrativa dos fatos, sendo desnecessária a qualificação jurídica. (Cf. BUENO, Cássio Scarpinella. Curso Sistematizado de direito processual civil. 3. ed. São Paulo: Saraiva, 2009. v. 1, p. 380).
} 
coisa julgada, ou por transgressão a uma possível litispendência, tal como determina a lei processual (CPC, art. $301, \mathrm{~V}$ e VI, $\S 1^{\circ}$ e $3^{\circ}$, cc. art. $\left.267, \mathrm{~V}\right){ }^{142}$

Em outros dizeres, o artigo 285-A do Código de Processo Civil não exige sejam as demandas idênticas às demais ações já propostas, muito pelo contrário. Referido dispositivo tem aplicação naqueles casos em que as petições iniciais são uniformizadas, sendo relativas a casos semelhantes em que matéria jurídica e quadro fático do caso paradigma e da causa a ser apreciada são os mesmos, bastando, pois, ao juiz alterar os nomes das partes para prolação da sentença de improcedência.

Portanto, para que a fundamentação empregada em sentença anterior seja aproveitada em outra, por casos idênticos deve-se entender aqueles que apresentam o mesmo pedido (objeto) e as mesmas causas de pedir (remota e próxima), não bastando apenas uma delas. É o que sucede, normalmente, nas chamadas demandas de massa, tais como aquelas que envolvem questões previdenciárias, tributárias, direitos do consumidor, entre outras, onde se discute a mesma tese jurídica. ${ }^{143}$

Há, é bom frisar, aqueles que defendem que a identidade prevista na norma referese apenas aos "fundamentos fáticos e jurídicos da demanda proposta e os dos casos paradigmas de improcedência declinados pelo julgador, admitindo-se, obviamente, a diversidade de partes, como também a diversidade de pedido". ${ }^{144}$ Todavia, nos parece que o mais acertado é que para a caracterização dos casos idênticos, além da identidade da causa de pedir remota e próxima, exista também identidade dos pedidos. ${ }^{145}$

$\mathrm{O}$ art. 285-A do CPC tem por intuito adaptar as regras do processo à realidade da litigância contemporânea. Nesse sentido, os casos idênticos referidos na norma dizem respeito àqueles relativos a demandas de massa, apresentando a mesma argumentação,

\footnotetext{
${ }^{142}$ WAMBIER, Luiz Rodrigues; WAMBIER, Teresa Arruda Alvim; MEDINA, José Miguel Garcia. Breves comentários à nova sistemática processual civil 2. São Paulo: Ed. Revista dos Tribunais, 2006. p. 67.

${ }^{143}$ Cf. DIDIER JÚNIOR, Fredie. Curso de direito processual civil: teoria geral do processo e processo de conhecimento. 14. ed. Salvador: Ed. JusPodivm, 2012. v. 1, p. 488.

${ }^{144}$ PINTO, Fernanda Guedes. As ações repetitivas e o novel art. 285-A do CPC (racionalização para as demandas de massa), cit., p. 139. Ainda no mesmo sentido: ATAÍDE JÚNIOR, Vicente de Paula. A resolução antecipada do mérito em ações repetitivas (lei 11277/2006). Revista de Processo, São Paulo, v. 31 n. 141, p. 122, nov. 2006.

145 Outro não é o entendimento de Gilberto Gomes Bruschi: “O que, na verdade, o legislador pretendeu dizer por casos idênticos foi causas que contenham a mesma tese jurídica, que podem ser detectadas nas ações com mesma causa de pedir e mesmo pedido, desde que com partes diferentes”. (BRUSCHI, Gilberto Gomes. Casos idênticos e os requisitos para a aplicação do art. 285-A do CPC. Revista Dialética de Direito Processual, São Paulo, n. 78, p. 23, set. 2009).
} 
apenas se adaptando ao caso concreto, ajustando os nomes das partes e seus dados pessoais. $^{146}$

Em suma, o artigo em referência impõe celeridade processual, já que não há obrigação de formação da relação processual, sendo dispensada a citação do réu, para julgamento da lide em primeira instância. Contudo, não podemos esquecer que havendo qualquer peculiaridade na demanda que aguarda por julgamento ou naquelas já analisadas, não possui o magistrado autorização legal para a prolação de sentença liminar.

Indo adiante, apesar de não existir expressa menção no artigo, tal qual constava no projeto original da Lei n. 11.277/06, de que o mesmo se aplicará a "processos repetitivos", fato é que, na prática, o artigo vem sendo amplamente utilizado para abreviar o julgamento de demandas cujo destino já se conhece de antemão, diante dos precedentes existentes sobre certos temas jurídicos. ${ }^{147}$

Tratando sobre as partes existentes nas demandas repetitivas, observa-se que, regra geral, encontraremos em um dos polos do processo a presença de um litigante habitual.

Nesse sentido, recente relatório publicado pelo Departamento de Pesquisas Judiciárias (DPJ), após coletar e organizar dados recebidos sobre os maiores litigantes dos tribunais estaduais, regionais federais e do trabalho (excluíram-se, além dos processos criminais, aqueles relativos à Justiça Eleitoral, Justiça Militar e Infância e juventude), apresentou listagem dos 100 maiores litigantes nacionais, sendo que as dez primeiras colocações, em âmbito nacional, não surpreendentemente, foram ocupadas por órgãos Públicos, bancos e empresa de telefonia. ${ }^{148}$

\footnotetext{
${ }^{146}$ CUNHA, Leonardo José Carneiro da. Primeiras impressões sobre o art. 285-A do CPC (julgamento imediato de processos repetitivos: uma racionalização para as demandas de massa), cit., p. 96.

${ }^{147}$ Ressalta Ana Laura González Poittevin que a identidade de casos prevista no dispositivo legal não é a identidade de ações art. 301, § $2^{\circ}$, do CPC, sendo que a mesma "deve ser entendida como processos nos quais se discute a mesma tese jurídica, aplicada a uma mesma situação fática. São os chamados processos repetitivos, tão comuns em uma sociedade de massa, na qual o Judiciário não está ao alcance de uma minoria apenas." O art. 285-A do CPC e os embargos de declaração. In: MEDINA, José Miguel Garcia et al (Coord.). Os poderes do juiz e o controle das decisões judiciais: estudos em homenagem à Professora Teresa Arruda Alvim Wambier. São Paulo: Ed. Revista dos Tribunais, 2008. p. 621.

${ }^{148} \mathrm{Na}$ sequência, os dez maiores litigantes nacionais listados pela pesquisa: INSS, CEF, Fazenda Nacional, União, Banco do Brasil, Estado do Rio Grande do Sul, Banco Bradesco, Banco Itaú, Brasil Telecom Celular e Banco Finasa. Com efeito, o DPJ lançou as seguintes conclusões: “(...) o setor público (Federal, Estadual e Municipal), bancos e telefonia representam 95\% do total de processos dos 100 maiores litigantes nacionais. Desses processos, $51 \%$ têm como parte ente do setor público, $38 \%$ empresa do setor bancário, 6\% companhias do setor de telefonia e 5\% de outras empresas. Do total de processos dos 100 maiores litigantes nacionais, 59\% referem-se ao pólo passivo, sendo o comportamento do Setor Público Municipal diferente dos demais, uma vez que $97 \%$ dos processos desse setor referem-se ao pólo ativo". (Fonte: Departamento de Pesquisa Judiciárias/ CNJ).
} 
Chama atenção e até ocasiona certo grau de perplexidade o fato do art. 307 do PL 8.046/10 nada dispor sobre tal exigência em sua redação, estando tal necessidade, em nosso sentir, implícita.

\subsubsection{Anterior sentença de improcedência do juízo}

No tocante à expressão improcedência total, entende-se que não se admite julgamento prévio do mérito nas hipóteses de procedência ou procedência parcial, ainda que a matéria seja unicamente de direito, porque essas decisões seriam prejudiciais ao demandado, que não teve oportunidade de defender-se, cogitando-se cerceamento de defesa. $^{149}$

Para que haja aplicação do julgamento prima facie nos casos de demandas repetitivas, não se exige que a sentença seja, na íntegra, de total improcedência, bastando igualdade da causa de pedir e pedidos entre a demanda em andamento e aquelas que servirão como paradigma. ${ }^{150}$

Convém esclarecer, por oportuno, que quando se fala em reprodução da sentença anterior, o que se pretende é a reprodução dos fundamentos e do dispositivo da sentença anteriormente proferida, devendo o magistrado preparar o relatório do caso apresentado e na fundamentação reproduzir os fundamentos do julgado paradigma, justificando a similitude com a situação colocada em discussão. Assim, não se pretendeu afastar a necessidade de atendimento aos requisitos formais da sentença, quais sejam, a presença do relatório, da fundamentação e do dispositivo, conforme dispõe o art. 458 do Código de Processo Civil.

\footnotetext{
${ }^{149}$ Nesse sentido, leciona Eduardo Cambi que se fosse possível julgamento antecipado nas hipóteses de procedência ou procedência parcial "restaria comprometida a garantia do contraditório - já que não se respeitaria a isonomia entre as partes (o demandado não teria as mesmas chances ou igual oportunidade de poder influenciar no convencimento judicial) -, a garantia da ampla defesa (no qual se incluem todos os meios e recursos capazes de buscar a persuasão do órgão julgador; art. $5^{\circ}$, inc. LV, CF), além de infringir a noção basilar do devido processo legal, segundo o qual ninguém pode ser privado de sua liberdade ou de seus bens sem um processo regular (art. $5^{\circ}$, inc. LV, CF). Logo, a sentença, pela ausência da citação do demandado, que não tem oportunidade de influir no convencimento judicial, deve ser, integralmente, favorável ao réu”. (Julgamento prima facie (imediato) pela técnica do art. 285-A do CPC. Disponível em <www.abdpc.org.br/artigos/artigo1033.doc>. Acesso em: 09 jun. 2011).

${ }^{150}$ Nos dizeres de Elpídio Donizetti, “o que importa é a coincidência do pedido sob julgamento e o que serve de paradigma. O pedido é que deve ter sido julgado totalmente improcedente, não a sentença”. (DONIZETTI, Elpídio. Curso didático de direito processual civil, cit., p. 331).
} 
Nesse sentido, deve o magistrado pronunciar-se em sentença exclusiva, onde deve arrazoar os motivos da identidade da causa com a anterior que serve de paradigma, a fim de aplicar o art. 285-A, não havendo óbice para o reforço argumentativo. O que se admite é que o magistrado reaproveite o texto de julgados anteriormente proferidos (em especial, fundamentação e decisão), inserindo-os nas novas sentenças.

Não se trata, contudo, apenas de juntar cópia reprográfica da sentença modelo ou ainda de fazer menção no texto decisório, sendo necessário, em virtude do princípio da motivação, que se demonstre a adequação do paradigma ao caso concreto, isto é, que se aponte os pontos de coincidência que permitem o emprego da "sentença-tipo", com dados que a identifiquem. ${ }^{151}$ Tal reivindicação tem por intuito assegurar o princípio da ampla defesa e possibilitar à parte autora fundamentos para eventual recurso a fim de demonstrar a falta de identidade entre os casos.

Além da reprodução do teor da sentença-paradigma (e não juntada de cópia reprográfica ${ }^{152}$ ) no corpo da sentença que se está a proferir, até porque é esta que será registrada em livro próprio, há aqueles que defendem uma providência a mais, qual seja, a indicação da numeração de alguns dos processos paradigmas anteriormente decididos, a fim de se permitir à parte um maior controle sobre o real desacolhimento das demandas precedentes pelo juízo, bem como aferição da similitude com o caso atual.

Com efeito, o que se quer com o dispositivo não é a mera juntada de cópia da sentença paradigma, tal qual prevê o artigo 12 do regime processual experimental

\footnotetext{
${ }^{151}$ Cf. DIAS, Jean Carlos. A introdução da sentença-tipo no sistema processual civil brasileiro - Lei n. 11277. Revista Dialética de Direito Processual, São Paulo, n. 37, p. 68, abr. 2006.

${ }^{152}$ Como reforço argumentativo, confira-se: "DIREITO PROCESSUAL CIVIL. JULGAMENTO IMEDIATO DA LIDE. ARTIGO 285-A DO CÓDIGO DE PROCESSO CIVIL. EXIGÊNCIA DE TRANSCRIÇÃO E ANEXAÇÃO DE CÓPIAS ALÉM DA TRANSCRIÇÃO DAS SENTENÇAS PROFERIDAS ANTERIORMENTE. DESNECESSIDADE. 1.- Para o acórdão recorrido, o artigo 285-A do Código de Processo Civil que, diante de inicial, autoriza a imediata prolação de sentença de improcedência, exigiria, implicitamente, além das transcrições das sentenças proferidas anteriormente e que servem de paradigma para a solução abreviada do feito, a juntada de cópia dessas sentenças para verificação da coincidência entre o seu conteúdo e o que foi reproduzido no corpo da decisão. 2.- O entendimento, embora lastreado no princípio constitucional da fundamentação das decisões judiciais, cria requisito que não existe na lei. 3.- A exigência legal de que sejam transcritas as sentenças anteriores já assegura a observância do direito fundamental em questão em seu "mínimo necessário". A transcrição das sentenças paradigma já é, em regra, suficiente para revelar o processo cognitivo de subsunção realizado pelo julgador e também para permitir à parte a interposição de um recurso bem instruído e bem fundamentado. 4.- A exigência extra de que sejam juntadas as cópias das referidas sentenças, quando já houve a transcrição do seu conteúdo, depõe contra os princípios da celeridade e da economia processual que serviram justamente de inspiração para a lei. 5. Além disso, na apelação que se interponha poderá ser contestada a transcrição, submetendose a matéria ao crivo do Tribunal. 6.- Recurso Especial provido.” (REsp 1086991/MG, Rel. Ministro SIDNEI BENETI, TERCEIRA TURMA, julgado em 16/08/2011, DJe 06/09/2011)
} 
português ${ }^{153}$ ou, ainda, que no texto decisório faça o juiz alusão à sentença paradigma, (motivação per relationem), isto é, que o juiz simplesmente remeta as partes ao quanto decidido em outra demanda. Tal prática importaria violação do preceito contido no art. 93, IX, da Constituição Federal segundo o qual "todos os julgamentos dos órgãos do Poder Judiciário serão públicos, e fundamentadas todas as decisões, sob pena de nulidade (...)".

É de se ressaltar, ainda, que não basta a existência de apenas uma sentença de improcedência, pois a lei se utiliza do plural, expondo a obrigatoriedade da existência prévia de dois ou mais paradigmas para que a causa possa ser apreciada. ${ }^{154}$

Em que pese não exista na lei referência à necessidade de que sentença paradigma esteja acobertada pela coisa julgada, há aqueles que sustentam que tal conduta seria mais apropriada e propiciaria uma maior segurança jurídica. Com todo o respeito àqueles que pensam desta forma, ousamos discordar de tal interpretação, já que tal exigência significaria limitar a aplicação do dispositivo, restringindo os poderes do magistrado de primeiro grau. ${ }^{155}$

Isto porque, se o entendimento esposado em primeira instância contar com um histórico de reformas, deve o julgador ter consciência de que se trata de posição superada, inclusive considerando que deve seguir a orientação dos julgados dos tribunais superiores, colaborando para a uniformização de jurisprudência, cuja ausência, conforme exposto

\footnotetext{
${ }^{153}$ Segundo texto de referido artigo: "I - Sempre que possivel, nomeadamente quando a simplicidade da causa o permita, a sentença, julgando a matéria de facto e de direito, é sucintamente fundamentada e logo ditada para a acta. 2 - Em caso de procedência do pedido, o juiz pode, com valor de decisão condenatória, limitar- se a conferir força executiva à petição, aderindo aos fundamentos apresentados pelo autor ou remetendo para sentença ou acórdão anterior, de que junta cópia. 3 - Em caso de improcedência da acção, o juiz pode, com valor de decisão absolutória, limitar-se a absolver o réu da instância ou do pedido, mediante simples adesão aos fundamentos alegados pelo réu na contestação ou oposição ou remetendo para sentença ou acórdão anterior, de que junta cópia.4 - Se, na sua decisão, o juiz aderir a um acórdão de uniformização de jurisprudência deve limitar-se a remeter para os seus fundamentos, juntando cópia. 5 - As regras previstas nos números anteriores aplicam-se, com as devidas adaptações, aos despachos interlocutórios."

${ }^{154}$ Compartilham de tal entendimento: WAMBIER, Luiz Rodrigues; WAMBIER, Teresa Arruda Alvim; MEDINA, José Miguel Garcia. Breves comentários à nova sistemática processual civil 2, cit., p. 67. Mantovanni Colares Cavalcante, de outra banda, em que pese não expresse um número, salienta que " $o$ precedente só pode nascer em face de reiteradas decisões, pois esse é o símbolo da firmação do entendimento cristalizado a respeito da tese jurídica". (A sentença liminar de mérito do art. 285-A do Código de Processo Civil e suas restrições, cit., p. 100).

${ }^{155}$ Dessa ótica, Vicente de Paula Ataíde assevera que: "a lei não faz nenhuma ressalva quanto às condições da sentença paradigma. Isso quer dizer que essa sentença, que será utilizada como referência para os casos posteriores idênticos, não precisa estar acobertada pela coisa julgada, podendo, mesmo, ter sido reformada em grau de recurso. Se o juiz da causa concordar com a tese jurídica da sentença paradigma, não importa a confirmação ou a reforma desta: a sentença paradigma passará a ser a sentença do juiz da causa e o entendimento nela contido, dele será”. (ATAÍDE JÚNIOR, Vicente de Paula. A resolução antecipada do mérito em ações repetitivas (lei 11277/2006), cit., p. 122).
} 
anteriormente, gera grande quantidade de recursos, um dos pontos que contribuem para a atual morosidade processual.

Indo adiante, estabelece o dispositivo em questão, ainda, a necessidade de que a sentença de improcedência a ser reproduzida tenha sido proferida "no juízo". Surge, aqui, mais um questionamento diante da falta de técnica de redação do artigo.

O Juízo é o órgão jurisdicional que pode ser titularizado de modo monocrático ou colegiado. Nesse sentido, destacamos que como órgão jurisdicional há que se incluir os Tribunais, e neste, seus "vários órgãos jurisdicionais, como as câmaras cíveis e criminais isoladas; as câmaras cíveis e criminais reunidas, o tribunal pleno ou o órgão especial, dentre outros". 156

Importante salientar que há não há consenso doutrinário quanto à interpretação da palavra "juízo”. Há aqueles que argumentam que a lei estabelece que as decisões pretéritas sejam proferidas pelo mesmo juiz, primando por sua identidade física, uma vez que o entendimento é pessoal, fruto do livre convencimento do juiz e não do Juízo. ${ }^{157}$ Logo, um juiz substituto não poderia se valer das sentenças anteriormente proferidas pelo juiz titular, deveria, assim, proferir sentença, após a citação do réu, e somente depois de decidido pelo menos dois casos semelhantes é que poderia se valer da técnica em comento.

Fernanda Guedes Pinto defende no tocante à autoria da sentença paradigma, que esta deverá ter sido proferida pelo mesmo juízo que tenha sido o autor do ato sentencial, sendo que "o art. 285-A exige, para sua incidência, a identidade física do juiz prolator das sentenças paradigmas". ${ }^{158}$

Este tipo de entendimento, contudo, pode favorecer situações inusitadas: imaginemos o caso de um juiz substituto de uma Vara Federal de São Paulo que seja promovido para uma Vara Federal de Mato Grosso do Sul (ambas pertencentes ao Tribunal Regional Federal da $3^{\text {a }}$ Região). Em sendo o precedente do juiz, poderia o magistrado ao chegar a seu novo local de trabalho julgar improcedente demanda, dispensada a citação, valendo-se da ratio decidendi dos julgados proferidos em São Paulo.

\footnotetext{
${ }^{156}$ KLIPPEL, Rodrigo; SARTÓRIO, Élvio Ferreira. A aplicação do art. 285-A ao julgamento dos mandados de segurança de competência originária dos tribunais. In: ALVIM, Arruda; ARRUDA ALVIM, Eduardo. Atualidades do processo civil. Curitiba: Juruá, 2007. v. 1, p. 402.

${ }^{157}$ CAMBI, Eduardo. Julgamento prima facie (imediato) pela técnica do art. 285-A do CPC, cit.

${ }^{158}$ Cf. PINTO, Fernanda Guedes. As ações repetitivas e o novel art. 285-A do CPC (racionalização para as demandas de massa), cit., p. 143. Na doutrina, contudo, há quem entenda que a norma em análise esteja a se referir aos juízes, não aos juízos, posicionamento seguido por KOEHLER, Frederico Augusto Leopoldino. Breve análise sobre alguns aspectos polêmicos da sentença liminar de improcedência (artigo 285-A do CPC). Revista Dialética de Direito Processual, São Paulo, n. 41, p. 72, ago. 2006.
} 
Outros combatem tal entendimento sob o fundamento de que a norma legal exige que "as decisões paradigmas tenham sido proferidas no mesmo juízo, isto é, na mesma Vara onde tramite a nova ação”. 159

Há, por fim, aqueles que defendem que a orientação que permitiria aproveitar ao máximo a nova regra, garantindo maior agilidade e presteza jurisdicionais, é aquela que prevê que qualquer magistrado (substituto ou titular) poderia proferir julgamento prévio de improcedência fazendo uso de sentenças paradigmas proferidas por outros juízes dentro da mesma comarca ou subseção judiciária. ${ }^{160}$

Nos filiamos à corrente intermediária, que defende para a aplicação do artigo 285-A do CPC, que na mesma vara, ainda que por outro juiz, já tenha sido anteriormente enfrentada e julgada integralmente improcedente determinada pretensão, respeitados os demais requisitos legais.

É de se salientar e lamentar o fato de que o Projeto de Lei 8.046/10 nada diz acerca da possibilidade do julgamento ter por base o entendimento formado em primeiro grau, em virtude da análise reiterada da matéria em outros casos anteriores, em sentido oposto à pretensão formulada pela parte autora. Tal reserva, ao que tudo indica, surge como clara opção legislativa de restringir a atuação do juiz de primeira instância, e pode significar o decurso da utilização dessa técnica. ${ }^{161}$

\footnotetext{
${ }^{159}$ GAJARDONI, Fernando da Fonseca. O princípio constitucional da tutela jurisdicional sem dilações indevidas e o julgamento antecipadíssimo da lide, cit., p. 161. Do mesmo sentir, Jean Carlos Dias esclarece: "como a atuação processual tal como regulada no nosso Código não é da pessoa mas do órgão que ela incorpora, é razoável supor que a expressão utilize como referência a unidade funcional da jurisdição, como de resto o fazem as regras processuais, notadamente as relacionadas à competência”. (DIAS, Jean Carlos. A introdução da sentença-tipo no sistema processual civil brasileiro - Lei n. 11277, cit., p. 67).

${ }^{160}$ ATAÍDE JÚNIOR, Vicente de Paula. A resolução antecipada do mérito em ações repetitivas (lei 11277/2006), cit., p. 121.

${ }^{161}$ Vale dizer que aqui concordamos com a afirmação de José Tadeu Neves Xavier no sentido de que: " $O$ projeto de novo Código de Processo Civil, no entanto, deixa de dar seguimento ao caminho trilhado pela criação da possibilidade do julgamento prima facie, e, em uma guinada de mudança de direção, passa a propor que o julgamento de improcedência liminar do pedido seja colocado à disposição, em especial, do ideal de verticalização da tutela jurisdicional, atuando como mecanismo de efetivação, em sede de primeiro grau, das determinações fixadas pelos Tribunais Superiores por meio de seus enunciados de súmulas e julgamento de recursos repetitivos." (XAVIER, José Tadeu Neves. Julgamento de improcedência prima facie em ações repetitivas na sistemática processual civil atual e no contexto do projeto de novo Código de Processo Civil. Revista Jurídica. Sapucaia do Sul, v. 59, n. 404, p. 42, jun. 2011).
} 


\subsection{A utilização de súmula e/ou jurisprudência dominante do Supremo Tribunal Federal ou de Tribunal Superior como caso paradigma}

Ao nos debruçarmos sobre o estudo da técnica prevista no art. 285-A do CPC, questão que surge refere-se à possibilidade de, inexistindo no juízo de primeiro grau sentença anteriormente prolatada sobre o tema, o magistrado fazer uso de precedente do Tribunal.

Outra indagação oportuna é se pode o magistrado fazer uso de seus próprios julgados quando estes divergirem de orientação sumulada ou predominante dos Tribunais.

Em que pese a norma em comento não exija que o entendimento adotado na sentença copiada tenha transitado em julgado, tampouco tenha sido confirmado por órgão recursal superior àquele que proferiu a sentença-paradigma, fato é que parcela da doutrina defende que tal dispositivo deve ser interpretado em conformidade com outras regras e princípios processuais, especialmente aqueles relacionados à estabilização das decisões judiciais.

\subsubsection{Análise do cabimento da utilização de Súmula e/ou Jurisprudência dominante como caso paradigma pelo Juízo}

Inicialmente, convém verificar se apesar de não existir qualquer ressalva na redação do art. 285-A do CPC, poderia o juiz, para fins de julgamento prévio pela improcedência de demanda repetitiva, utilizar como caso paradigma posicionamento sumulado (seja através de súmula vinculante nos moldes do art. 103-A da CF que somente podem ser editadas pelo STF, ou súmulas comuns, assim entendidas aquelas editadas sem necessidade de quórum qualificado e que sejam veiculadas pelo STF ou pelo STJ) ou jurisprudência dominante do respectivo tribunal, do Supremo Tribunal Federal, ou de Tribunal Superior.

A fim de angariar subsídios para responder a esse questionamento, oportuno mostra-se conceituar o que vem a ser súmula e jurisprudência dominante. Ressalte-se, ainda, que a súmula com efeito vinculante já foi objeto de análise no Capítulo 1 do presente trabalho. 
No que tange à súmula, esta apresenta conceito que não enseja maiores dúvidas, pois o próprio Código de Processo Civil, em seu artigo 479, versa que "o julgamento, tomado pelo voto da maioria absoluta dos membros que integram o tribunal, será objeto de súmula e constituirá precedente na uniformização da jurisprudência”.

Em que pese não possua força de lei, a súmula "funciona, de acordo com o Regimento Interno do Tribunal, como instrumento de dinamização dos julgamentos e valioso veículo de uniformização jurisprudencial, como tem evidenciado a prática do Supremo Tribunal Federal". ${ }^{62}$

Se não há dificuldade na conceituação de súmula, o mesmo, infelizmente, não se pode dizer da expressão “jurisprudência dominante”, eis que ainda não foi adotado um critério majoritário, tanto na doutrina quanto na jurisprudência, sobre como conceituá-la.

O que se pode dizer, de antemão, é que súmula e jurisprudência dominante são conceitos que não se confundem, “aquela tem o enunciado emitido nos termos regimentais e legais, esta expressa o entendimento ordinariamente seguido, mas que não mereceu ainda o patamar sumular". ${ }^{163}$

Tratando-se de tema que comporta várias significações, forçoso se faz delimitar o sentido adotado na abordagem ora empreendida. Interessa, pois, a acepção de jurisprudência como "coleção ordenada de acórdãos consonantes e harmônicos sobre uma determinada matéria, no âmbito de uma dada Justiça ou de um dado Tribunal. "164

Cândido Rangel Dinamarco procura trazer sua contribuição para compreensão da expressão asseverando que "jurisprudência dominante será não somente aquela já estabelecida em incidentes de uniformização da jurisprudência, mas também a que estiver presente em um número significativo de julgados, a critério do relator". ${ }^{165}$

Priscila Kei Sato sinaliza a existência de critérios já determinados para verificação de jurisprudência dominante no Supremo Tribunal Federal, quais sejam: a) existência de

\footnotetext{
${ }^{162}$ THEODORO JÚNIOR, Humberto. Curso de direito processual civil: teoria geral do direito processual civil e processo de conhecimento, cit., v. 1, p. 649.

${ }^{163}$ SLAIBI FILHO, Nagib. Notas sobre o art. 557 do CPC. Competência do relator de prover e de negar seguimento a recurso. Jus Navigandi, Teresina, ano 7, n. 62, fev. 2003. Disponível em: <http://jus2.uol.com.br/doutrina/texto.asp?id=3792>. Acesso em: 11 nov. 2007.

${ }^{164}$ MANCUSO, Rodolfo de Camargo. A jurisprudência, dominante ou sumulada, e sua eficácia contemporânea. In: NERY JÚNIOR, Nelson; WAMBIER, Teresa Arruda Alvim (Coords.). Aspectos polêmicos e atuais dos recursos cíveis de acordo com a lei 9.756/98. São Paulo: Ed. Revista dos Tribunais, 1999. p. 530.

${ }^{165}$ DINAMARCO, Cândido Rangel. O relator, a jurisprudência e os recursos. In: NERY JÚNIOR, Nelson; WAMBIER, Teresa Arruda Alvim (coord.). Aspectos polêmicos e atuais dos recursos cíveis de acordo com a lei 9.756/98. São Paulo: Ed. Revista dos Tribunais, 1999. p. 134.
} 
mais de um acórdão que reflita aquele entendimento, ou unicidade de decisão, desde que esta faça menção de outros julgados no mesmo sentido; b) decisão do Tribunal Pleno, mesmo que não unânime. ${ }^{166}$

Luiz Rodrigues Wambier, por sua vez, rebate tais argumentos, sob o fundamento de que os mesmos não são suficientes para descrever o conceito de "jurisprudência dominante". Sustenta referido autor a necessidade de que a constatação da jurisprudência dominante se dê com base em dados objetivos e de forma delimitada no tempo. ${ }^{167}$

Como se vê, trata-se de tema complexo, cujo consenso parece estar longe de ser alcançado. Todavia, ao que nos propomos analisar, vislumbramos que o magistrado somente está obrigado a decidir seguindo orientação expressa em súmula vinculante do Supremo Tribunal Federal. Com efeito, somente há previsão de eficácia vinculante às súmulas do STF, não se estendendo tal vinculação às súmulas do STJ, hipótese em que deixou o legislador à discricionariedade do julgador.

Por tais razões, não nos parece que seja possível ao órgão judicante fazer uso da faculdade procedimental prevista no art. 285-A do CPC somente com base em súmula comum ou orientação jurisprudencial predominante, quando inexistente, no próprio juízo, decisões anteriores que tenham acolhido a tese jurídica a ser adotada.

Não é este ideário, contudo, que parece que vai prevalecer no novo Projeto de Código de Processo Civil, uma vez que o artigo 307, em seus incisos I a III, faz tão somente menção à possibilidade de julgamento liminar de improcedência quando o pedido não estiver em harmonia com súmula e acórdão proferido em julgamento de recursos repetitivos pelo STF e STJ, bem como quando não estiver em consonância com posicionamento firmado em incidente de resolução de demandas repetitivas ou de assunção de competência.

\footnotetext{
${ }^{166}$ SATO, Priscila Kei. Jurisprudência (Pre) Dominante. NERY JÚNIOR, Nelson; WAMBIER, Teresa Arruda Alvim (Coords.). Aspectos polêmicos e atuais dos recursos. São Paulo: Ed. Revista dos Tribunais, 2000. p. 579.

167 "Quanto ao mais, pensamos que um critério aceitável para o "preenchimento" desse conceito indeterminado seria sua delimitação no tempo. É preciso um período referencial para que se possa falar em jurisprudência dominante. Assim, o entendimento da Corte Especial do Superior Tribunal de Justiça, a respeito da interpretação do direito federal, poderia considerar-se dominante se houvesse a reiteração de decisões majoritárias daquela Corte, no mesmo sentido, na proporção de $70 \%$ por $30 \%$, durante o período de cinco anos (ou três anos, ou dois anos, por exemplo, contados retroativamente). E poder-se-ia pensar na flexibilização da questão, permitindo-se a subida de recurso ao Superior Tribunal de Justiça (e, portanto, a vedação ao ato do Tribunal inferior, a teor do art. 557, com base na jurisprudência dominante), na medida em que naquele Tribunal Superior houvesse demonstração de tendência à alteração do entendimento, o que poder-se-ia aferir pelo estreitamento das proporções entre um e outro entendimentos (60\% por $40 \%$, por exemplo)". (WAMBIER, Luiz Rodrigues. Uma proposta em torno do Conceito de Jurisprudência Dominante. Revista de Processo. São Paulo, v. 25 n. 100, p. 85, out./dez. 2000).
} 


\subsubsection{Confronto entre o entendimento do juiz de primeiro grau e súmula / jurisprudência do Supremo Tribunal Federal e Tribunal Superior}

Havendo incompatibilidade entre o posicionamento do juiz de primeira instância e a jurisprudência dominante do tribunal local, do STJ e do STF, da mesma forma como não há sentido que o relator, no tribunal de segundo grau, utilize de seus poderes monocráticos para ajustar uma decisão, ou sentença, conforme a jurisprudência em seu Tribunal dominante, mas em dissonância com a dominante nos tribunais superiores, também não seria lógico permitir tal conduta aos juízes. ${ }^{168}$

Com efeito, a interpretação sistemática do processo civil, leva-nos a concluir que a prolação de sentença com fulcro no art. 285-A deve estar em consonância com súmula ou jurisprudência dominante do respectivo Tribunal superior ao juízo de $1^{\circ}$ grau, Supremo Tribunal Federal ou Superior Tribunal de Justiça.

A respeito do tema, confira-se lição de Cássio Scarpinella Bueno:

Por mais convencido que esteja um específico "juízo" de primeiro grau de jurisdição sobre uma dada tese jurídica, outras vozes sobre ela, eventualmente dissonantes, existem nos diversos graus de jurisdição, inclusive no primeiro, em outros juízos, em outras varas, e que não podem ser desconsideradas. (...) A sentença de primeiro grau só poderia ser utilizada como paradigma interpretativo para os fins propugnados pelo art. 285-A na exata medida em que ela, a sentença, estivesse em plena consonância com as decisões dos Tribunais recursais competentes. ${ }^{169}$

\footnotetext{
${ }^{168}$ Nesse sentido, confira-se: "Afirma-se aqui, como premissa de trabalho, que o art. 285-A tem por escopo a aceleração do processo, não a "uniformização da jurisprudência do juizo”, de sorte que o juiz, ao sentenciar, deverá valer-se de seus precedentes (ou os do juízo, na dicção da lei) se e quando já previamente confirmados em sede recursal, ou, à míngua deles, de precedentes de tribunais, mormente, embora não exclusivamente, os já enunciados em súmula. Aliás, dispensa-se totalmente a existência de outros precedentes para o julgamento initio litis quando impositiva a aplicação, no caso concreto, de súmula vinculante, pois esta, além de expressar a interpretação final do Supremo Tribunal Federal, representa, ela própria, o resultado de reiterados julgamentos sobre matéria constitucional”. (MARCATO, Antonio Carlos. Crise da Justiça e influência dos precedentes judiciais no direito processual civil brasileiro, cit., p. 214-215). Assim também se posiciona Paulo Afonso de Souza Sant'anna (Ações repetitivas e julgamento liminar (art. 285-A do CPC). Revista Dialética de Direito Processual, São Paulo, n. 70, p. 109-110, jan. 2009).

${ }^{169}$ BUENO, Cássio Scarpinella. A nova etapa do Código de Processo Civil: comentários sistemáticos às Leis n. 11.276 de 7-2-2006, 11.277, de 7-2-2006, e 11.280, de 16-2-2006, cit., v. 2, p. 53.
} 
Convergimos com o posicionamento da maioria dos doutrinadores no sentido de considerar tal aspecto como um requisito implícito da norma ${ }^{170}$, que se apóia no direito constitucional à razoável duração do processo.

Concordamos com esse entendimento e acrescentamos que não há imposição para que o magistrado profira sentença liminar de improcedência da demanda repetitiva pelo simples fato de existir súmula do tribunal a que está vinculado ou de tribunais superiores. Contudo, em que pese o art. 285-A assim não tenha expressado, não parece razoável permitir que possa o magistrado decidir de acordo com sentença antes proferida em caso idêntico, quando esta estiver em contrariedade com súmula destes tribunais. ${ }^{171}$

Nesse sentido, convém destacar que restou decidido no julgamento do recurso especial (REsp) 1109398, pela Quarta Turma do Superior Tribunal de Justiça, que o artigo 285-A do CPC não deve ser aplicado em decisões antagônicas à jurisprudência consolidada nos tribunais superiores, sobretudo junto ao Superior Tribunal de Justiça e Supremo Tribunal Federal. Isto porque, nas palavras do ministro Luis Felipe Salomão, relator do feito, "permitir que se profiram decisões contrárias a entendimentos consolidados, ao invés de racionalizar o processo, seguramente acaba por fomentar o inconformismo da parte vencida e contribui com o patológico estado de litigiosidade verificado atualmente". 172

Conclui-se que, não havendo entendimento sumulado dos Tribunais sobre o caso em julgamento, o juiz terá a faculdade de aplicar o dispositivo em comento baseando-se

\footnotetext{
${ }^{170}$ Com bem referiu Fernanda Guedes Pinto, "uma interpretação teleológica do preceito permite reconhecer, como mens legis do novo texto, a otimização da celeridade processual e da estabilidade judiciária, mas pelo caminho da valorização das decisões de primeira instância quando convergirem para a súmula de jurisprudência dos tribunais superiores". (PINTO, Fernanda Guedes. As ações repetitivas e o novel art. 285-A do CPC (racionalização para as demandas de massa), cit., p. 131).

${ }^{171}$ A esse respeito, confira-se oportuna lição de Rogerio Mollica: "De nada adianta os Tribunais Superiores serem contrários à tese defendida nos autos e o juiz de primeira instância julgar o processo procedente, pois nesse caso só estará "vendendo uma ilusão" ao Autor e fazendo que o Réu e o Judiciário gastem tempo e recursos até que o processo chegue aos Tribunais, para que a sentença seja reformada, com a aplicação do entendimento pacificado. O mesmo acontece no caso inverso, no qual a tese é amplamente aceita pelos Tribunais Superiores e o juiz de primeira instância julga improcedente o pedido. Nesse caso, o Autor terá de pagar custas para apelar (muitas vezes exorbitantes), aguardar a distribuição e o julgamento da apelação ou recursos especial e extraordinário, para só então ter aplicado o entendimento pacificado. Ademais, com o exagerado formalismo dos nossos Tribunais, é capaz que seus recursos não sejam conhecidos por uma filigrama jurídica e o processo não atingirá o seu escopo de pacificação social e de entregar justiça." (MOLICA, Rogerio. Os processos repetitivos e a celeridade processual. 2010. Tese (Doutorado) - Faculdade de Direito da Universidade de São Paulo, São Paulo, 2010. p. 82-83).

${ }^{172}$ REsp 1109398/MS, Rel. Ministro LUIS FELIPE SALOMÃO, QUARTA TURMA, julgado em 16/06/2011, DJe 01/08/2011. Disponível em: <https://ww2.stj.jus.br/revistaeletronica/Abre_Documento.asp?sLink=ATC\&sSeq=15993682\&sReg=2008 02832871\&sData=20110801\&sTipo=91\&formato=PDF>. Acesso em: 27 dez. 2012.
} 
tão somente em sentença de improcedência anteriormente proferida no próprio juízo sentenciante, o que majora de forma considerável o seu âmbito de incidência. Contudo, havendo entendimento consolidado pelos Tribunais acerca do assunto, mister que o julgador apenas faça uso do permissivo legal caso a sentença paradigma não seja incompatível com referida orientação do Superior Tribunal de Justiça ou com o Supremo Tribunal Federal.

Conforme abordado no item precedente, a nova redação proposta para a técnica da improcedência de plano do pedido busca assegurar expressamente que as sentenças proferidas estejam em consonância com o posicionamento dos Tribunais, trazendo, inclusive, certa restrição ao que preconiza o art. 285-A.

\subsection{Sentença de improcedência de plano e demandas com pedidos cumulados: análise da possibilidade de cisão do julgamento}

De acordo com a redação do art. 285-A do CPC, em caso de sentença de improcedência prima facie, o autor poderá apelar e o réu, caso não ocorra o juízo de retratação, será citado para responder ao recurso. Em regra, do provimento jurisdicional que julga o pedido totalmente improcedente com fulcro no art. 285-A o recurso cabível é o de apelação.

A problemática surge, porém, nos casos de cumulação de pedidos autônomos entre si. O CPC permite que em um único processo o autor cumule pedidos, de sorte que uma demanda faça o papel de tantos quantos forem os pedidos. Basta, para tanto, a existência de compatibilidade entre os pedidos, identidade de competência e de procedimento.

Em primeiro lugar, pertinente o questionamento acerca do cabimento ou não de julgamento parcial de pedidos, isto é, da cisão do julgamento da causa.

Parte da doutrina preconiza que se houver cumulação de pedidos e em um deles não couber a aplicação do dispositivo do art. 285-A do CPC, dever-se-á citar o réu para apresentar defesa, não sendo possível ao magistrado julgar os pedidos em momentos distintos, devendo aguardar para decidir tudo ao final do processo. Argumenta-se que deve o juiz buscar preservar o sistema de concentração da decisão, sendo que a utilização do art. 
285-A somente deve ocorrer quando todas as pretensões contidas na inicial comportarem julgamento liminar. ${ }^{173}$

De acordo com tal pensamento, existindo, por exemplo, dois pedidos, e havendo apenas julgados anteriores de improcedência a respeito de um deles, não poderia o juiz fracionar o julgamento, repetindo a decisão pretérita para um pedido e determinando o prosseguimento quanto ao outro, acerca do qual ainda não houve qualquer pronunciamento no juízo.

Argumenta-se que tal conduta afastaria a razão de ser da aplicação do julgamento de improcedência de plano, uma vez que de qualquer maneira o réu seria citado para responder os demais pedidos. Assim, recomenda-se que nos casos em que houver diversos pedidos, se um deles não comportar o julgamento segundo o art. 285-A do CPC, deverá o juiz citar o réu e julgar todos em uma só oportunidade, após formado o contraditório. ${ }^{174}$

Adotando posicionamento diverso, Luiz Guilherme Marinoni afasta o dogma da unicidade de julgamento por entender que este princípio não mais se coaduna com a atual sistemática processual, desde que um dos pedidos formulados pelo autor esteja maduro para julgamento, quer por se referir a matéria apenas de direito ou, ainda, por não ensejar a necessidade de instrução probatória. ${ }^{175}$

Cândido Rangel Dinamarco que inicialmente mostrava-se desfavorável a essa possibilidade $^{176}$, parece ter alterado seu entendimento, conforme se verifica de edição mais recente de sua obra, quando afirma que o sistema processual brasileiro comporta a possibilidade de cisão do julgamento quando tratar-se de “cisões referentes a parcelas do objeto do processo, decidindo o juiz sobre uma delas e mandando que o processo siga

\footnotetext{
${ }^{173}$ Nesse sentido, Umberto Bara Bresolin ressalta que "sempre que a causa subseqüente trouxer algo novo, algum elemento objetivo que inexista nos precedentes, qualquer um que seja, já não se perfará a hipótese de casos idênticos e, diante da impossibilidade de cisão do julgamento do mérito, não terá lugar o julgamento do mérito, não terá lugar o julgamento ex vi do artigo 285-A”. (BRESOLIN, Umberto Bara. Considerações sobre o artigo 285-A do Código de Processo Civil, cit., v. 1, p. 391). Do mesmo sentir: BONDIOLI, Luís Guilherme Aidar. O julgamento liminar de improcedência da demanda da óptica do réu (art. 285-A do CPC), cit., p. 15 e CIMARDI, Cláudia A. Notas sobre o art. 285-A do CPC (sentença liminar de improcedência), cit., p. 417.

${ }^{174}$ Cf. MONNERAT, Fábio Victor da Fonte. Primeiras aplicações do art. 285-A do CPC. Revista de Processo, São Paulo, v. 33 n. 157, p. 237, mar. 2008.

${ }^{175}$ MARINONI, Luiz Guilherme. Tutela antecipatória e julgamento antecipado: parte incontroversa da demanda. 5. ed. rev. atual. São Paulo: Ed. Revista dos Tribunais, 2002. p. 139.

${ }^{176}$ DINAMARCO, Cândido Rangel. Instituições de direito processual civil. 6. ed. São Paulo: Malheiros Ed., 2002. v. 3, p. 669.
} 
avante para a instrução e julgamento referente às demais”, sendo esse julgamento parcial denominado como sentença. ${ }^{177}$

É na sentença que o juiz acolhe ou rejeita, no todo ou em parte, o pedido formulado pelo autor (art. 459). Essa prática transgride também o disposto no art. 458, inc. II, do Código de Processo Civil, segundo o qual é na motivação da sentença que o juiz deve examinar as questões relativas ao meritum causae. Tal é o princípio da unidade da sentença, que só pode ser contrariado quando uma específica norma de direito o autorizar (Liebman).

Diante de tais considerações, vislumbra-se que não há tanto no art. 285-A, quanto no ordenamento jurídico de modo geral, qualquer ressalva suficientemente séria que afaste a possibilidade de, existindo dois pedidos cumulados, e existindo no juízo decisões de improcedência no tocante a um deles, possa o juiz se utilizar tais decisões para o julgamento liminar somente desse pedido.

Nesse caso, o magistrado poderá proferir julgamento prévio do mérito quanto ao pedido repetido, reproduzindo sentença anterior e, no tocante aos demais pedidos cumulados, determinar a citação. Isto porque, segundo palavras de Daniel Amorim Assumpção Neves, "não se pode previamente descartar a hipótese de sentenças liminares que julguem apenas parcela da pretensão do autor improcedente, desde que presentes todos os requisitos previstos pelo art. 285-A, caput, do CPC”. ${ }^{178}$

A discussão acerca da possibilidade de cisão do julgamento não é questão nova no ordenamento jurídico processual, tendo sido suscitada quando da introdução pela Lei $10.444 / 2002$ do $\S 6^{\circ}$ no art. 273 do CPC, quanto à possibilidade de julgamento antecipado dos pedidos incontroversos. ${ }^{179}$

Paulo Afonso de Souza entende que as situações previstas pelo $\S 6^{\circ}$ do art. 273 e pelo art. 285-A do CPC são distintas. Para o autor, como na hipótese do art. 285-A um dos pedidos cumulados é julgado improcedente, não havendo qualquer modificação no mundo empírico, deveria se aguardar para julgamento em conjunto dos pedidos. ${ }^{180}$

\footnotetext{
${ }^{177}$ DINAMARCO, Cândido Rangel. Instituições de direito processual civil, cit., 6.ed., v. 3, p. 700.

${ }^{178}$ Cf. NEVES, Daniel Amorim Assumpção. Recurso contra a sentença de improcedência liminar (art. 285-A do CPC) e o juízo de retratação. Revista Dialética de Direito Processual, São Paulo, n. 54, p. 48, set. 2007.

${ }^{179}$ ALVIM, Eduardo Arruda. Do julgamento de improcedência de casos repetitivos, à luz da lei $\mathrm{n}^{\mathbf{o}}$ 11.277/2006 - algumas reflexões atinentes ao art. 285-A do CPC, cit., p. 47.

${ }^{180}$ SANT'ANNA, Paulo Afonso de Souza. Ações repetitivas e julgamento liminar (art. 285-A do CPC), cit., p. 106.
} 
Para aqueles que admitem a possibilidade de julgamento cindido, questionáveis são a natureza do pronunciamento judicial que aplica o art. 285-A em face apenas de um ou alguns dos pedidos (por não encerrar totalmente o processo e fundar-se no artigo 269, I), se sentença ou decisão interlocutória de mérito, bem como qual o recurso cabível ante tal decisão.

Importante ressaltar que a atual redação do $\S 1^{\circ}$ do artigo 162 do Código de Processo Civil dada pela Lei $\mathrm{n}^{\mathrm{o}} 11.232 / 2005$, modificou o conceito legal de sentença, eliminando a caracterização de que poria fim ao processo, harmonizando-a com a fase de cumprimento, sem instauração de uma nova relação jurídica processual. Foi definida, portanto, como o ato judicial que aplica os artigos 267 e 269 do referido Estatuto Processual, ou seja, pelo seu conteúdo. ${ }^{181}$

Com referida alteração, sendo a sentença definida por seu conteúdo, entende-se que foi suprimido o grande entrave que havia para que se considerasse como sentença parcial a decisão que aprecia apenas um ou mais pedidos considerados maduros para julgamento antes dos demais formulados de forma cumulativa, em que pese tal provimento não encerre o processo. ${ }^{182}$ Tratando-se de sentença, resultado de cognição plena, está ela apta a produzir coisa julgada material, tão logo restem esgotados os meios impugnatórios.

Luiz Orione Neto de modo diverso, e com o qual não concordamos, defende que o pronunciamento judicial que julga apenas um ou alguns dos pedidos recursivos, por reprodução de julgado anterior, teria natureza de decisão interlocutória. ${ }^{183}$

Denota-se que, tal como ocorre nos casos de julgamento antecipado da lide quanto apenas um ou alguns pedidos, a discussão parece estar longe de ser encerrada. A análise do recurso cabível diante do pronunciamento judicial que, nos casos de ação que cumula mais de um pedido, julga um ou alguns deles, de plano, improcedente, com base no art. 285-A, será objeto de estudo no Capítulo que segue a este.

\footnotetext{
181 “Em termos mais extensos, sentença deve ser conceituada como o provimento judicial que, resolvendo ou não o mérito da causa, põe termo, em primeiro grau, ao ofício de julgar do magistrado relativamente a um certo pedido." (REDONDO, Bruno Garcia. Sentença parcial de mérito e apelação em autos suplementares. Revista de Processo, Sâo Paulo, v. 33, p. 144, n. 160, jun. 2008).

${ }^{182}$ Corroborando esta afirmação, tem-se que "toda a vez que o juiz exercer cognição exauriente, ainda que relativamente apenas à parcela da pretensão deduzida pelo autor, autoriza-se o julgamento definitivo, com prolação de sentença parcial." NOGUEIRA, Glaucia Assalin. O julgamento parcial: possibilidade de cisão do julgamento de mérito relativamente à parte incontroversa da demanda. Dissertação (Mestrado) Faculdade de Direito, Universidade de São Paulo. 2009. p. 131.

${ }^{183}$ ORIONE NETO, Luiz. Recursos cíveis: teoria geral, princípios fundamentais, dos recursos em espécie, tutela de urgência no âmbito recursal, da ordem dos processos no tribunal. 3. ed. São Paulo: Saraiva, 2009. p. 234.
} 


\subsection{Participação do MP (na qualidade de custos legis) e o Art. 285-A}

O Ministério Público é instituição que, após a Constituição Federal de 1988, ganhou posição singular no Estado brasileiro, conforme se percebe da leitura do art. 127, caput: “O Ministério Público é instituição permanente, essencial à função jurisdicional do Estado, incumbindo-lhe a defesa da ordem jurídica, do regime democrático e dos interesses sociais e individuais indisponíveis”.

Em sua tese de doutorado, José Carlos Baptista Puoli salienta a posição de destaque dada pela Constituição ao Ministério Público. Indo adiante, questiona se dado o seu grau de independência em relação aos demais órgãos, poderia ser o mesmo considerado um quarto Poder. Após discorrer brevemente acerca da teoria da separação dos poderes, conclui "haver coincidência de escopos em grau suficiente para negar a existência de um quarto poder e caracterizar o MP com um órgão que, em que pese seu amplo grau de autonomia, efetivamente desenvolve função executiva”. 184

Costuma-se apontar, no processo civil, duas formas de participação do Ministério Público, quais sejam: como parte e como custos legis. ${ }^{185}$

Fala-se, em primeiro lugar, de seu desempenho como litigante, oportunidade em que terá os mesmos poderes e ônus atribuídos às partes. Ressalte-se, por oportuno, que o Ministério Público poderá ser autor somente nos casos previstos em lei, exigindo-se, assim, norma expressa (seja ela constitucional ou infraconstitucional). ${ }^{186}$

O art. 82, por seu turno, prevê a segunda hipótese de intervenção ministerial, quando ele atuará como fiscal da lei ou custos legis, velando pela adequada aplicação da lei em casos a que se atribui peculiar estima, tais como: a) processos em que incapaz for parte ou assistente, independentemente de sua posição no feito ou espécie de direito em disputa (patrimonial ou moral); b) processos em que a natureza do objeto litigioso tenha correlação

\footnotetext{
${ }^{184}$ Cf. PUOLI, José Carlos Baptista. Responsabilidade civil do promotor de justiça na tutela a interesses metaindividuais. Tese (Doutorado) - Faculdade de Direito da Universidade de São Paulo, São Paulo, 2005. p. 39-42.

${ }^{185}$ Cf. BOTELHO DE MESQUITA, Ignácio. A garantia do devido processo legal - aplicação contra excesso do Ministério Público. Revista Forense, Rio de Janeiro, v. 327, p. 149-154, jul./set. 1994. p. 151.

${ }^{186}$ Nos dizeres de Carlos Alberto de Salles: "A legitimação processual do Ministério Público, em matéria de direitos e garantias constitucionais, se dá a partir da verificação da existência de interesse social, assim caracterizado como aqueles difusos ou coletivos, na situação de fato considerada, devendo-se levar em conta, para tanto, não só a violação em concreto de direito constitucionalmente estabelecido, mas também a potencialidade ofensiva do ato de natureza administrativa”. (SALLES, Carlos Alberto de. A legitimação do Ministério Público para defesa de direitos e garantias constitucionais, cit., p. 129).
} 
direta com estado da pessoa, pátrio poder, tutela, curatela, interdição, casamento, declaração de ausência e disposições de última vontade; c) litígios coletivos pela posse da terra rural (nos termos da Lei 9.415/96); d) hipóteses em que, nos termos do inciso III, haja interesse público evidenciado pela natureza da lide ou qualidade da parte.

No tocante aos casos em que se faz necessária a intervenção do órgão ministerial, questão que se apresenta diz respeito à possibilidade de se proferir sentença sem antes proceder à intimação do parquet, diante do silêncio do legislador quanto à atuação do órgão na qualidade de fiscal da lei.

Estando a causa abarcada na previsão do art. 82 (ou de outro análogo), o Ministério Público deve participar, sob pena de nulidade, exigindo o CPC que seja determinada sua cientificação, bem como lhe seja oportunizado manifestar-se nos autos.

O projeto do novo CPC trata da participação do Ministério Público nos artigos 154 a 159. O papel do MP enquanto fiscal da ordem jurídica é ressaltado no art. 156 que prevê em seus incisos I a IV as hipóteses em que será necessária sua intervenção. Da leitura do art. 157, por sua vez, destaca-se a possibilidade do parquet participar da atividade probatória, requerer as medidas que entender necessárias e recorrer, além de ser intimado de todos os atos do processo, sob pena de nulidade (art. 254).

Quer nos parecer que, nos casos em que prevê a lei a necessidade de sua participação, não pode o magistrado julgar improcedente a demanda, aplicando o art. 285A do CPC, sem antes permitir ao Ministério Público que este exare seu parecer na qualidade de fiscal da lei. ${ }^{187}$

Em que pese tal conduta possa fazer com que o mecanismo perca parcialmente seu sentido de possibilitar o julgamento de mérito de plano, deve-se atentar que no caso deve sobressair um interesse maior a ser protegido pelo juiz (o interesse social), sendo que a intervenção ministerial somente na fase recursal poderia ser ineficaz ante a irreversibilidade dos efeitos do julgado e a irreparabilidade total dos interesses possivelmente lesados.

\footnotetext{
${ }^{187}$ No mesmo sentido: CERQUEIRA, Fábio Ruiz; MAIDAME, Márcio Manoel. Art. 285-A do CPC: fundamentos, importância e aplicabilidade no processo civil brasileiro. In: ALVIM, Arruda; ARRUDA ALVIM, Eduardo. Atualidades do processo civil. Curitiba: Juruá, 2007. v. 1, p. 358.
} 


\subsection{Aplicação do Art. 285-A no âmbito dos tribunais, em termos de competência originária}

A estrutura do Poder Judiciário brasileiro é composta por diversos órgãos judicantes, sendo necessária a distribuição do exercício da jurisdição entre estes para sua melhor atuação. Denomina-se competência essa delimitação prévia constitucional e legal da jurisdição. ${ }^{188}$

A fixação da competência se dá através de um processo lógico, em fases sucessivas, que passa pela verificação da competência internacional, justiça e foro competente. ${ }^{189}$ Para tanto, o legislador se utiliza de critérios variados tais como espaço, matéria, pessoa e valor da causa.

A determinação da competência, momento em que se identifica qual o juízo que concretamente vai julgar a causa ocorre, nos termos do art. 87 do CPC, na data da propositura da ação. A ação se considera proposta, por sua vez, na data da distribuição ou não havendo necessidade de distribuição, na data do despacho inicial.

A esse respeito convém salientar que são irrelevantes as modificações do estado de fato ou de direito ocorridos posteriormente, em virtude da chamada regra da perpetuação da jurisdição. Assim, identificado o juízo competente para a causa, é lá que a causa será julgada, pouco importa o que aconteça posteriormente. Esta regra atribui estabilidade ao processo, e só será excepcionada em razão de supressão do órgão judiciário onde a causa está sendo processada ou em virtude de alteração superveniente de competência absoluta (em razão da matéria ou hierarquia).

No tocante à atribuição das causas aos diversos órgãos judiciários, havendo mais de um juízo competente para atuar na mesma causa, o legislador busca fazer sua distribuição

\footnotetext{
${ }^{188}$ Diz-se, pois que "enquanto a jurisdição é abstrata e se relaciona com a função soberana de pacificar as lides aplicando a lei ao caso concreto, temos, de outro lado, a figura da competência, que permitirá a cristalização dessa jurisdição, ou seja, o seu exercício in concreto”. (RODRIGUES, Marcelo Abelha. Manual de direito processual civil. São Paulo: Ed. Revista dos Tribunais, 2008. p. 87).

${ }^{189}$ Acerca do assunto, confira-se: "Para fazer essa distribuição, procede o legislador, certamente apoiado na experiência secular de que o informa a doutrina, mediante três operações lógicas: a) constituição diferenciada de órgãos judiciários; b) elaboração da massa de causas em grupos (levando em conta certas características da própria causa e do processo mediante o qual ela é apreciada pelo órgão judiciário); c) atribuição de cada um dos diversos grupos de causas ao órgão mais idôneo para conhecer destas, segundo uma política legislativa que leve em conta aqueles caracteres e os caracteres do próprio órgão". (CINTRA, Antônio Carlos de Araújo; DINAMARCO, Cândido Rangel; GRINOVER, Ada Pellegrini. Teoria geral do processo, cit., p. 252).
} 
ora tendo por critério o interesse público, ora o interesse das partes, ora a conjugação de ambos os interesses.

Nesse passo, importante o papel do critério funcional, que tomado sob o ângulo de um só processo, que é o que nos interessa neste momento, pode ser analisado sob o plano vertical e sob o plano horizontal. No plano horizontal, o legislador redistribui as funções entre órgãos situados no mesmo plano (no processo penal, por exemplo, a competência do juiz do júri e do conselho de sentença ou, ainda, no processo civil, a expedição de uma carta precatória solicitando providências do outro juízo responsável pela colheita de uma prova). No primeiro vertical, verifica-se a divisão de competência entre instâncias (competência originária e derivada). ${ }^{190}$

Em regra, a competência originária compete à primeira instância que deverá analisar e julgar inicialmente a ação apresentada ao Poder Judiciário. As decisões por ela proferidas poderão ser submetidas à análise da instância superior, dando oportunidade às partes conflitantes de obterem o reexame da matéria.

Excepcionalmente, contudo, cabe aos órgãos jurisdicionais de segundo grau ou tribunais de cúpula apreciar originariamente determinadas ações, isto é, fazer o primeiro exame da causa. No que se refere às Cortes brasileiras de última instância, a Constituição Federal dispõe sobre a competência originária do Supremo Tribunal Federal e do Superior Tribunal de Justiça nos artigos 102, II e 105, II, respectivamente. Demais casos de competência originária dos tribunais são estabelecidos em lei federal ou nas Constituições dos Estados.

No presente tópico, pretendemos discorrer sobre a possibilidade de incidência da inovação trazida pelo art. 285-A do Código de Processo Civil pelos tribunais, em termos de competência originária.

Para tanto, vamos analisar se a redação do dispositivo, ao incluir termos tipicamente de primeira instância, seria óbice à sua aplicação em ações de competência originária dos Tribunais.

Ademais, convém perquirir se a sua localização dentro do Código de Processo Civil, na seção destinada aos requisitos da petição inicial, seria pecha ao seu emprego pelos órgãos de segundo grau.

\footnotetext{
${ }^{190}$ Cf. RODRIGUES, Marcelo Abelha. Manual de direito processual civil, cit., p. 87.
} 
Como já tivemos a oportunidade de abordar, fica claro que com o emprego da expressão "sentença do juízo", não pretendeu o legislador cristalizar sua aplicação aos órgãos de primeiro grau de jurisdição, sujeitando às partes de ações distribuídas perante os tribunais a delonga de uma demanda a respeito de cujo tema já se tenha firmado convicção. $^{191}$

Atento a esse quadro, Eduardo Arruda Alvim assinala não haver motivos plausíveis para restringir a incidência do dispositivo apenas às ações iniciadas na primeira instância. Enfatiza, ainda, que à terminologia "casos idênticos" a que alude o artigo em comento “basta que os precedentes tenham sido proferidos no mesmo juízo”, o que a seu ver "pode ser transportado às Turmas, Câmaras e demais órgãos fracionários dos tribunais, ao julgarem os processos de sua competência originária, mesmo porque a lei não veda tal possibilidade”. ${ }^{192}$

Por fim, destacamos que recentes manifestações da jurisprudência, no que diz respeito à aplicação do art. 285-A do CPC, indicam tendência favorável quando se trata de ações de competência originária dos Tribunais. ${ }^{193}$

\footnotetext{
${ }^{191}$ Nesse sentido: "Defender que juízo e sentença são palavras que inibiriam, por seu emprego, a extensão da aplicação do art. 285-A em sede de tribunal, seria até mesmo um contrasenso em face da comum assertiva contrária. Assim sendo, afasta-se qualquer impedimento terminológico ou topológico que a norma possa ter, para fins de sua aplicação ao julgamento dos mandados de segurança de competência dos tribunais". (KLIPPEL, Rodrigo; SARTÓRIO, Élvio Ferreira. A aplicação do art. 285-A ao julgamento dos mandados de segurança de competência originária dos tribunais, cit., v. 1, p. 402).

${ }^{192}$ Cf. ALVIM, Eduardo Arruda. Do julgamento de improcedência de casos repetitivos, à luz da Lei ${ }^{\circ}$ 11.277/2006 - algumas reflexões atinentes ao art. 285-A do CPC, cit., p. 46.

${ }^{193}$ Nesse sentido, confira-se: "PREVIDENCIÁRIO. AGRAVO REGIMENTAL EM AÇÃO RESCISÓRIA. APLICAÇÃO DO ART. 285-A DO CPC. IMPROCEDÊNCIA DO PEDIDO. MATÉRIA PRELIMINAR REJEITADA. APOSENTADORIA POR IDADE A RURÍCOLA. NÃO OCORRÊNCIA DE ERRO DE FATO. RECURSO DESPROVIDO. - Rejeitada a matéria preliminar arguida pela autarquia, de ausência de documento essencial. - Não há óbice à aplicação do art. 285-A do CPC em ações de competência originária dos Tribunais, desde que satisfeitas todas as exigências legais inerentes à espécie. - A ocorrência ou não, na hipótese dos autos, da circunstância prevista no inc. IX do art. 485 do código processual civil consubstancia tema de direito, a permitir o julgamento da causa pelo art. 285-A do CPC. Improcedência do pedido rescisório. - Matéria preliminar rejeitada. Agravo regimental desprovido." (TRF - $3^{\mathrm{a}}$ Região, $3^{\mathrm{a}}$ Seção, AgRegAR 002750359.2009.4.03.0000/SP, Rel. Des. Fed. Vera Jucovsky, v. u., D.E. 8/11/2010). Cf., ainda: "DIREITO PROCESSUAL CIVIL E PREVIDENCIÁRIO. AÇÃO RESCISÓRIA. DECISÃO MONOCRÁTICA. POSSIBILIDADE. APLICAÇÃO, POR ANALOGIA, DOS ARTS. 557 E 275A, AMBOS DO CPC. APOSENTADORIA POR IDADE RURAL. ART. $3^{\circ}, \S 1^{\circ}$, LEI 10.666/2003. INTERPRETAÇÃO CONTROVERTIDA. PEDIDO RESCISÓRIO COM FULCRO NO INCISO V (VIOLAÇÃO A LITERAL DISPOSIÇÃO DE LEI) DO ART. 485 DO CPC. INOCORRÊNCIA DE LITERAL VIOLAÇÃO A DISPOSITIVO DE LEI. PEDIDO RESCISÓRIO IMPROCEDENTE. DECISÃO AGRAVADA MANTIDA. RECURSO IMPROVIDO. (...) II - As disposições do art. 285-A, e do art. 557, ambos do CPC, são aplicáveis às ações rescisórias julgadas improcedentes monocraticamente (porque fadadas ao insucesso), pois esses preceitos legais possibilitam a celeridade e a racionalização do julgamento de processos repetitivos, imprimindo um novo iter procedimental, em respeito à garantia fundamental da duração razoável do processo prevista no art. $5^{\circ}$, LXXVIII, da Constituição Federal. Precedentes: AR 0002367.89.2011.4.03.0000, julg. 08.02.2011 - Rel ${ }^{a}$. Des. ${ }^{a}$. Federal Vera Jucovsky; AR 0000490-
} 


\subsubsection{Utilização do art. 285-A no julgamento dos mandados de segurança de competência dos tribunais}

Indagação oportuna que surge ao analisar o teor do art. 285-A diz respeito à possibilidade de sua utilização no âmbito dos tribunais. Num primeiro momento, verificaremos se a técnica ali contida é hábil a ser empregada no julgamento dos mandados de segurança de competência originária dos tribunais.

Na Constituição Federal o mandado de segurança está previsto no art. 5º, LXIX ${ }^{194}$, sendo que atualmente o mandado de segurança, ação civil de rito sumário especial, encontra-se disciplinado pela Lei $\mathrm{n}^{\circ} 12.016$ de 17 de agosto de 2009 e apenas de forma subsidiaria se aplica o Código de Processo Civil.

Trata-se o mandado de segurança de ação constitucional que procura proteger direito individual ou coletivo, líquido e certo, não amparado por habeas corpus ou habeas data, de lesão ou ameaça de ato de autoridade, assim entendido qualquer agente público formalmente investido e no desempenho de uma função pública. ${ }^{195}$

Inicialmente, convém fazer algumas ponderações acerca do conceito de direito líquido e certo. Trata-se de tema muito discutido na doutrina e na jurisprudência, sendo que vem prevalecendo a tese de que a expressão direito líquido e certo está ligada à prova préconstituída, a fatos documentalmente provados com a inicial, constituindo verdadeira condição da ação de mandado de segurança. ${ }^{196}$

Hely Lopes Meirelles entende que direito líquido "é o que se apresenta manifesto na sua existência, delimitado na sua extensão e apto a ser exercitado no momento da

17.2011.4.03.0000, julg. 09.02.2011, Rel $^{a}$. Des ${ }^{a}$. Federal Marisa Santos, e AR 0029430-26.2010.4.03.0000, julg. 24.09.2010, Rel ${ }^{a}$. Des ${ }^{a}$. Federal Vera Jucovsky).

(...)”. (TRF3, Terceira Seção, Processo no 2010.03.00.027247-7, AR 7613, Relator Juiz Federal Carlos Francisco, votação unânime, DJF3 em 15.04.2011, página 30).

${ }^{194} \mathrm{O}$ art. $5^{\circ}$ da Constituição Federal diz expressamente: "LXIX - conceder-se-á mandado de segurança para proteger direito líquido e certo, não amparado por habeas corpus ou habeas data, quando o responsável pela ilegalidade ou abuso de poder for autoridade pública ou agente de pessoa jurídica no exercício de atribuições do poder público"

${ }^{195}$ Segundo Luiz Fux o mandado de segurança constitui “instrumento processual constitucional assegurado ao particular, seja pessoa física ou jurídica, brasileiro ou estrangeiro, na defesa de direito líquido e certo, individual ou coletivo, não amparado por habeas corpus ou habeas data, sempre que este for lesado (tutela repressiva) ou ameaçado de lesão (tutela preventiva) por ato ilegal, ou que implique em abuso de poder, praticado pela Administração Pública, através de seus agentes, na representação direta ou indireta da entidade pública”. (FUX, Luiz. Mandado de Segurança. 1. ed. Rio de Janeiro: Forense. 2010. p. 13).

${ }^{196}$ MACIEL, Adhemar Ferreira. Mandado de segurança: direito líqüido e certo. BDJur, Brasília, DF, 11 dez. 2007. p. 17-18. Disponível em: <http://bdjur.stj.gov.br/dspace/handle/2011/11481>. Acesso em: 01 jan. 2011. 
impetração." Ainda segundo o autor “o direito invocado, para ser amparável por mandado de segurança, há de vir expresso em norma legal e trazer em si todos os requisitos e condições de sua aplicação ao impetrante”. No mais, conclui: “direito líquido e certo é direito comprovado de plano. Se depender de comprovação posterior, não é liquido nem certo, para fins de segurança". 197

Cássio Scarpinella Bueno, por seu turno, assevera que, "por direito líquido e certo deve ser entendido aquele direito cuja existência e delimitação são claras e passíveis de demonstração documental”. 198

Em resumo, direito líquido e certo é aquele que não exige a produção de prova posterior, tendo em vista que o direito já está comprovado através de documentos anexados à petição inicial, não havendo que se falar, assim, em instrução probatória. Com efeito, se no caso em concreto os fatos forem imprecisos ou se for necessário maior instrução, a petição inicial do mandado de segurança deverá ser indeferida e o processo extinto sem julgamento de mérito. ${ }^{199}$

Considerações já foram feitas acerca dos requisitos para aplicação do artigo 285-A, quais sejam: ser a matéria objeto de discussão unicamente de direito (ou seja, independa de dilação probatória), e existência, no juízo que pretende aplicar referida técnica, de pronunciamento anterior, em outros casos idênticos, por meio de sentença.

A utilização pelos tribunais, nas causas de sua competência originária, de regramentos voltados inicialmente para pautar a atuação do juiz singular, mostra-se possível. Convém verificar, contudo, se a norma discutida no presente estudo está entre aquelas possíveis de receber uma interpretação ampliativa.

O primeiro requisito parece não suscitar dúvidas, uma vez que como visto a existência de direito líquido e certo é pressuposto para impetração do mandado de segurança, o que se coaduna com a desnecessária dilação probatória.

No tocante ao segundo requisito, passamos a fazer algumas observações.

\footnotetext{
${ }^{197}$ MEIRELLES, Hely Lopes. Mandado de segurança. 27. ed. São Paulo: Malheiros Ed., 2004. p. 36-37.

${ }^{198}$ BUENO, Cássio Scarpinella. Mandado de segurança: comentários às Leis n. 1.533/51, 4.348/64 e 5.021/66. 5. ed. São Paulo: Saraiva, 2009. p. 15.

${ }^{199}$ Sobre o assunto, aduz Vicente Greco Filho que: “o pressuposto do mandado de segurança, portanto, é a ausência de dúvida quanto à situação de fato, que deve ser provada documentalmente. Qualquer incerteza sobre os fatos decreta o descabimento da reparação da lesão por meio do mandado, devendo a parte pleitear seus direitos através de ação que comporte a dilação probatória”. (GRECO FILHO, Vicente. Direito processual civil brasileiro. 16. ed. atual. São Paulo: Saraiva, 2003. v. 3, p. 310).
} 
Apesar de constar da redação do artigo tão somente alusão a "sentença", fato é que despachos, decisões e acórdãos também são definidos pelo Código como atos do juiz e, em assim sendo, não constitui esta terminologia óbice para aplicação da técnica em comento.

No caso da aplicação do art. 285-A, o poder atribuído ao relator ficará até abaixo daquele previsto no art. 557 do CPC, motivo pelo qual não se vislumbra óbice para sua utilização como técnica de economia que impeça a efetivação de inúmeros atos processuais dispensáveis sede de competência originária.

Com efeito, aplica-se, subsidiariamente, o Código de Processo Civil ao procedimento previsto para a ação mandamental. Assim como concluímos ser possível o indeferimento liminar da inicial do mandado de segurança pela não observância das regras processuais para o processamento do feito, entendemos também ser plausível a aplicação do art. 285-A, do CPC, resultando no julgamento liminar de mérito. ${ }^{200}$

Precisa a lição doutrinária de Rodrigo Klippel e Élvio Ferreira Sartório para os quais em sendo possível a aplicação do conteúdo prescritivo do art. 285-A para o julgamento de mandados de segurança pelo juiz singular, muito mais o será no tocante aos Tribunais. $^{201}$

Releva destacar, neste contexto, que presentes as condições exigidas pelo dispositivo legal (que não faz restrição a qualquer espécie de procedimento), isto é, sendo a matéria só de direito e já tendo o juízo articulado sentença de total improcedência em casos anteriores, deve-se fazer proveito do julgamento prévio de mérito, ainda que se refira a mandado de segurança. ${ }^{202}$

\footnotetext{
${ }^{200} \mathrm{Com}$ efeito, o próprio Superior Tribunal de Justiça reconhece a aplicabilidade do art. 285-A aos mandados de segurança de competência originária dos Tribunais. Senão, vejamos: "ADMINISTRATIVO. RECURSO ORDINÁRIO EM MANDADO DE SEGURANÇA. CONCURSO PÚBLICO. CANDIDATO QUE POSTULA SUA NOMEAÇÃO. INDEFERIMENTO DA INICIAL. APRECIAÇÃO DO MÉRITO. IMPOSSIBILIDADE. RECURSO PROVIDO. 1. Ressalvadas as hipóteses de reconhecimento de decadência ou de aplicação da regra prevista no art. 285-A do CPC, é defeso ao relator indeferir liminarmente a inicial de mandado de segurança por razões de mérito. Precedentes do STJ. 2. Recurso ordinário provido”. (RMS 32.710/MG, Rel. Ministro ARNALDO ESTEVES LIMA, PRIMEIRA TURMA, julgado em 02/12/2010, DJe 16/12/2010). Também Fernanda Guedes Pinto mostra-se favorável à incidência da norma em comento no âmbito dos tribunais. (As ações repetitivas e o novel art. 285-A do CPC (racionalização para as demandas de massa), cit., p. 153).

${ }^{201}$ KLIPPEL, Rodrigo; SARTÓRIO, Élvio Ferreira. A aplicação do art. 285-A ao julgamento dos mandados de segurança de competência originária dos tribunais, cit., v. 1, p. 403.

${ }^{202}$ CUNHA, Leonardo José Carneiro da. Primeiras impressões sobre o art. 285-A do CPC (julgamento imediato de processos repetitivos: uma racionalização para as demandas de massa), p. 104.
} 
O julgamento da demanda com base no art. 285-A do CPC, obedecidos os requisitos ali elencados, deve ser feito expressamente, aludindo-se, ainda, aos fundamentos de decisões anteriormente proferidas pelo mesmo juízo em processos semelhantes.

\subsubsection{Utilização do art. 285-A no julgamento de ação rescisória}

Constitui a ação rescisória verdadeira ação prevista nos arts. 485 a 495 do CPC, que assim o sendo inicia-se por petição que deve atender aos requisitos do art. 282, sob pena de indeferimento (art. 490 do CPC). As causas de rescindibilidade constam de rol expresso e taxativo previsto no art. 485 do CPC. O que distingue a ação rescisória das demais ações é seu objetivo: tem por escopo a desconstituição de sentença de mérito já transitada em julgado. $^{203}$

Na Itália, os instrumentos que se assemelham à ação rescisória do direito brasileiro são o recurso de cassação (art. 360 do códice di procedura civile) e a revocazione (arts. 395 a 403 do Código de Processo Civil italiano de 1940). Contudo, tais instrumentos possuem natureza de recurso diferindo, assim, da natureza jurídica de ação que recebe no Brasil. No direito português, a rescisão da sentença também se dá por meio de um recurso, cabível após o trânsito em julgado da decisão, cujas hipóteses estão previstas no art. 771 do Código de Processo Civil de Portugal.

Destina-se, pois, a rescisória a anular o julgamento coberto pela coisa julgada, como tal entendida, a imutabilidade, dentro e fora do processo, da prestação jurisdicional do Estado, definitivamente entregue. ${ }^{204}$

A coisa julgada comporta desdobramento em coisa julgada formal e coisa julgada material. A imutabilidade do julgamento dentro do processo, em virtude de não mais comportar recurso, é a coisa julgada formal; a imutabilidade do julgamento fora do

\footnotetext{
${ }^{203}$ Nas palavras de Alexandre Freitas Câmara constitui a ação rescisória "demanda autônoma de impugnação de provimentos de mérito transitados em julgado, com eventual rejulgamento da matéria neles apreciada”. (CÂMARA, Alexandre Freitas. Ação rescisória. Rio de Janeiro: Lumen Juris, 2007. p. 30).

${ }^{204}$ Tendo em vista a fragilidade do conceito legal, procurou a doutrina definir coisa julgada. Para Humberto Theodoro Júnior a coisa julgada é "uma qualidade da sentença, assumida em determinado momento processual. Não é efeito da sentença mas a qualidade dela representada pela "imutabilidade" do julgado e de seus efeitos, depois que não seja mais possível impugná-los”. (THEODORO JÚNIOR, Humberto. Curso de direito processual civil: teoria geral do direito processual civil e processo de conhecimento, cit., v. 1, p. 537).
} 
processo em que se constituiu, impeditiva de seu reexame por qualquer juiz ou tribunal, é a coisa julgada material. ${ }^{205}$

Instalou-se, no direito pátrio, controvérsia acerca da possibilidade de ser rescindida uma decisão revestida apenas de coisa julgada formal (sentença da qual não caiba mais recurso), sendo que uma expressiva corrente de doutrinadores só admite a rescisão de coisa julgada material.

O pedido por excelência, na rescisória, é no sentido de desconstituir a sentença impugnada. Esse o chamado juízo rescindendo (judicium rescindens). Caso a sentença seja desconstituída, o processo primitivo estará sem um fim. Haverá casos em que a marcha processual deverá ser efetivamente retomada, cabendo ao tribunal, quando do juízo rescindendo, assim determinar. Em outras situações, no entanto, apenas a sentença (ou o acórdão) são atingidos, isto é, fica pendente somente um novo julgamento do processo original, sem prejuízo dos atos anteriores. Nesses casos, o pedido de rejulgamento é obrigatório.

O tribunal, fazendo o juízo rescisório (chamado de judicium rescisorium), apreciará a causa tal qual o faria se estivesse no lugar do juízo primitivo. Se estiver sendo reapreciada uma sentença, a decisão de mérito será do tribunal. Não caberão os mesmos recursos que haveria, fosse novamente prolatada decisão de primeiro grau.

O pedido formulado na ação rescisória, conforme aponta a doutrina, pode decompor-se em 2 (duas) pretensões, quais sejam, juízo rescindente e juízo rescisório: “ $a$ pretensão rescindente é desconstitutiva; a pretensão de re-julgamento pode dar origem a acórdão de qualquer espécie (variará conforme a natureza da causa que se busca ver novamente decidida: declaratória, constitutiva ou condenatória)."206

Na hipótese dos dois julgamentos (rescindendo e rescisório), será proferido único acórdão, que sucessiva e simultaneamente tratará deles. Aliás, o êxito na primeira etapa não garante sucesso na segunda. Suponha-se que a sentença rescindida tenha sido proferida por juiz impedido (único ato por ele praticado). Pode ocorrer que, reapreciada, o novo julgamento seja absolutamente coincidente com o anterior.

\footnotetext{
${ }^{205}$ SILVA, Bruno Freire e. Ação rescisória. Curitiba: Juruá, 2005. p. 28-29.

${ }^{206}$ DIDIER JÚNIOR, Fredie; CUNHA, Leonardo Carneiro da. Curso de direito processual civil: meios de impugnação às decisões judiciais e processo nos tribunais. 10. ed. Salvador: Ed. Jus Podivm, 2012. v. 3, p. 471.
} 
Em suma, regra geral, a ação rescisória invoca a manifestação dos dois juízos: rescindente e rescisório. Contudo, há hipóteses em que o tribunal limitar-se-á à manifestação sobre o juízo rescindente, pois será satisfatório ao caso rescindir a decisão para que seja restituída a autoridade da coisa julgada material produzida pelo pronunciamento jurisdicional prévio. São exemplos dessa situação os incisos I, II (em que o processo será renovado em primeiro grau) e IV do artigo 485 do CPC. ${ }^{207}$

A ação rescisória busca afastar do mundo jurídico decisão que, a despeito de ter alcançado a força da coisa julgada, conta com graves defeitos que afrontam a sua validade. Nos termos do art. 485 do CPC “A sentença de mérito, transitada em julgado, pode ser rescindida”. Na realidade, também acórdãos exarados pelos tribunais, ainda que no exercício de competência originária, estão sujeitos à rescisão.

Verifica-se, inclusive, que atualmente há um tendência na doutrina e jurisprudência de se admitir ajuizamento de ação rescisória de certas decisões. Como bem adverte Barbosa Moreira haverá preclusão se não interposto agravo contra a decisão monocrática do relator, produzindo esta "todos os efeitos atribuídos por lei ao julgamento colegiado, cujo lugar ocupou - revestindo até, se versar matéria atinente ao mérito da causa, a autoridade da coisa julgada substancial, e podendo constituir, então, objeto de ação rescisória”. ${ }^{208}$

Do exposto, entendemos que a decisão que se pretende rescindir por meio da ação rescisória pode ser tanto a sentença, quanto o acórdão, ou ainda, contra decisão interlocutória que tenha adentrado no mérito da causa. ${ }^{209}$

\footnotetext{
${ }^{207}$ THEODORO JÚNIOR, Humberto. Curso de direito processual civil. 36. ed. Rio de Janeiro: Forense, 2006. v. 3, p. 183.

${ }^{208}$ BARBOSA MOREIRA, José Carlos. Comentários ao Código de Processo Civil. 12. ed. Rio de Janeiro: Forense, 2005. v. 5, p. 668.

${ }^{209}$ A ementa do acórdão proferido pela Terceira Seção do TRF da $1^{\text {a }}$ Região, na Ação Rescisória 2003.01.00.036430-7/DF (j. 15/03/2005, DJ. 09/05/2005), da relatoria do Desembargador Federal Fagundes de Deus, consigna: “AÇÃO RESCISÓRIA. DECISÃO MONOCRÁTICA DE RELATOR QUE JULGOU APELAÇÃO NOS TERMOS DO ART. 557 DO CPC. OCORRÊNCIA DE ERRO DE FATO QUE ENSEJA A RESCISÃO DO JULGADO. 1. É cabível ação rescisória, quando a decisão rescindenda fundase em erro de fato consubstanciado na ausência de apreciação de prova relevante para o deslinde da causa. No caso, o Julgador reputou inexistente prova da retroação da opção pelo FGTS, quando o documento comprobatório encontrava-se nos autos. Circunstância em que o erro consubstanciou fator decisivo à errônea conclusão do julgado. (CPC, art. 485, inciso IX). 2. Devida a taxa progressiva de juros a titular de conta vinculada ao FGTS que manifestou opção retroativa, nos termos da Lei $n^{\circ}$ 5.958/73, e permaneceu na mesma empresa, pelo tempo legal exigido. 3. Hipótese em que não é de se confirmar a sentença, como pretende o Autor, na parte em que fixou honorários advocatícios em $5 \%$ sobre o valor da condenação, tendo vista ser aplicável, na espécie, a regra do art. 29-C da Lei 8.036/90, introduzido pela MP 2.164-40/2001. 4. Ação rescisória parcialmente procedente”.
} 
No tocante à possibilidade de aplicação da regra procedimental do art. 285-A no julgamento da ação rescisória, concluímos pela sua admissibilidade, à luz das conclusões lançadas sobre seu cabimento quanto ao mandado de segurança. Por oportuno, lançamos mão das considerações alinhavadas por Diego Cunha Maeso Montes:

Parece, contudo, que a teleologia e ontologia da Lei n. 11.277/06 não poderão ser desprestigiadas pelos Tribunais quando do julgamento da ação rescisória, pelo contrário. Em se tratando de uma ação excepcional, a ação rescisória somente deve ter prosseguimento quando o seu fundamento for plausível. Constatando que a ação rescisória não será provida, nada impedirá que o relator, valendo-se da faculdade prevista no art. 285-A do CPC, julgue-a improcedente, antes mesmo de citar o réu. Nessa hipótese, os princípios da celeridade, economia processual e efetividade, direitos fundamentais positivados no inciso LXXVIII do art. $5^{\circ}$ da CF/88, sobrepõem-se à letra fria do art. 491 do $\mathrm{CPC}^{210}$

Os operadores do direito não podem fazer vistas grossas à seriedade dos vícios que causam gravame à coisa julgada, previstos no art. 485 do Código de Processo Civil, motivo pelo qual devemos buscar a efetividade e celeridade no julgamento da ação rescisória. Aqueles casos em que a improcedência do juízo rescindendo é cristalina, não se verificando na decisão rescindenda nulidade ou injustiça violadora do ordenamento jurídico devem ser pronunciados de plano.

Em que pese haja previsão de citação da parte contrária feita pelo art. 491 do CPC, temos que protocolada a petição e sorteado o relator, a este caberá examiná-la para admitir ou não. Assim, pode o relator indeferir a inicial (art. 490 do CPC) ou, em sendo o caso, determinar ao autor que emende ou corrija a petição.

Contudo, estando em termos a inicial, nada há a impedir que o relator a defira e, afastando a necessidade de citação, e estando presentes os requisitos do art. 285-A, passe ao exame do mérito com o julgamento de plano pela improcedência. Isto porque a ação rescisória diz respeito, em regra, a assuntos apenas de direito, já debatidos e analisados pela decisão rescindenda.

\footnotetext{
${ }^{210}$ MONTES, Diego Cunha Maeso. O princípio do contraditório e a lei n. 11.277/06 (ART. 285-A DO CPC) utilização no procedimento da ação rescisória - aplicabilidade na Justiça do Trabalho. Caderno de Doutrina e Jurisprudência da Ematra XV, v. 2, n. 5, p. 253-254, set./out. 2006. Disponível em: <http://bdjur.stj.gov.br/xmlui/bitstream/handle/2011/35317/principio_contraditorio.pdf?sequence=1>. Acesso em: 27 de maio de 2011.
} 
É de se destacar que o art. 921, § $2^{\circ}$, do novo CPC, no tocante à ação rescisória, traz previsão expressa no sentido de que a mesma poderá ser rejeitada liminarmente nas hipóteses do art. 307.

Questão que surge, porém, diz respeito acerca da possibilidade do relator proferir decisão que envolva o mérito da rescisória. Em outras palavras, constatando o relator que o caso comporta, de plano, julgamento pela improcedência do pedido, pode fazê-lo monocraticamente ou deve, após proferir seu voto, remeter os autos para decisão do órgão colegiado ao qual pertence? Temos para nós que o relator possui competência para julgar improcedente a ação rescisória, nos termos do art. 285-A, sendo que contra tal decisão o recurso cabível será o agravo regimental, para o órgão colegiado do tribunal. 


\section{CAPÍtUlo III. QUESTÕES RECURSAIS ATINENTES À APLICABILIDADE DO ART. 285-A DO CPC}

\subsection{Considerações iniciais}

Releva destacar que o julgamento proferido pela técnica do art. 285-A, adicionada ao Código de Processo Civil pela Lei 11.277 de 2006, traz consigo um peculiar sistema recursal, que deve obedecer ao disposto nos $\S \S 1^{\circ}$ e $2^{\circ}$ da norma, os quais, contudo, parecem dizer menos do que deveriam.

Com o julgamento prévio de mérito, alguns caminhos se delineiam. Tendo o magistrado julgado improcedente o mérito da pretensão do autor, na forma do art. 285-A do CPC, surge para este, em caso de inconformismo em relação à decisão, a possibilidade de, dentro da mesma relação processual, e dentro de prazo determinado, utilizar meio processual visando o seu reexame por suposto vício. Em outras palavras, não estando de acordo com a decisão proferida, poderá o réu se valer de recurso tendo por finalidade a anulação, reforma, integração ou, ainda, o aclaramento do julgado impugnado.

Prevê o $\$ 1^{\circ}$ do art. 285-A do CPC que interposto recurso de apelação contra a referida sentença, será facultado ao juiz exercer o juízo de retratação, no prazo de cinco dias. Caso o magistrado não mantenha a sentença de improcedência proferida, determinará o prosseguimento regular do processo. Ressalte-se que neste momento, o magistrado não poderá rever sua decisão no sentido de julgar procedente ou parcialmente procedente o pedido, mas irá proferir decisão de único teor, anulação da sentença proferida no caso.

Por outro lado, caso decida o juiz por manter a sentença de improcedência proferida com incidência do art. 285-A, deverá o réu ser “citado", nos termos do §2º para responder o recurso de apelação.

Contudo, há, ainda, uma terceira possibilidade. Pode ocorrer que o réu, seja porque consentiu com o julgamento ou, ainda, porque não foi capaz de demonstrar seu inconformismo dentro dos prazos legais, fique inerte, isto é, não interponha qualquer recurso. 
Como se vê, com o julgamento do feito na forma do art. 285-A, abre-se a possibilidade para caminhos e consequências diferenciadas, que merecem uma análise com mais profundidade, da qual nos ocuparemos a partir desse ponto.

Entendemos pertinente alinhavar os nossos estudos com os princípios recursais. Isto porque, se por muito tempo se debitou aos princípios jurídicos papel secundário, hoje, de forma bem diferente, os mais renomados autores reconhecem o significativo papel dos princípios na compreensão do ordenamento jurídico.

Pode-se observar, assim, que os princípios são fundamentos sobre os quais se apoia determinada ciência, sendo que independentemente da área em que se emprega a noção de princípio, tem-se que o mesmo indica "a estruturação de um sistema de idéias, pensamentos ou normas por uma idéia mestra, por um pensamento chave, por uma baliza normativa, donde todas as demais idéias, pensamentos ou normas derivam, se reconduzem elou se subordinam". 211

É de se concluir que os princípios são pontos básicos para a elaboração e aplicação do direito. Diante das peculiaridades dos princípios inerentes a cada ramo do direito e da importância de sua aplicação, é que se torna extremamente necessário seu estudo e compreensão.

Os princípios podem ser divididos em quatro classes: onivalentes, plurivalentes, monovalentes e setoriais. Os primeiros são os princípios lógicos, presentes em qualquer ramo da ciência. Plurivalentes são os princípios comuns a determinado grupo de ciências, enquanto que os monovalentes são os válidos para determinado campo do conhecimento científico como, por exemplo, os princípios gerais de direito. Os princípios setoriais, por fim, são aqueles que dizem respeito apenas a um setor de determinada ciência. ${ }^{212}$

Nessa percepção, ainda dentro do processo civil, é possível abstrair num âmbito mais restrito, o dos princípios setoriais, a existência dos princípios fundamentais do

\footnotetext{
${ }^{211}$ Cf. ESPÍNDOLA, Ruy Samuel. Conceito de princípios constitucionais: elementos teóricos para uma formulação dogmática constitucionalmente adequada. 9. ed. rev. atual. e ampl. São Paulo: Ed. Revista dos Tribunais, 2002. p. 53.

${ }^{212}$ Cf. MARTINS, Nei Frederico Cano. Os princípios do direito do trabalho e a flexibilização ou desregulamentação. Revista da Faculdade de Direito de São Bernardo do Campo, São Bernardo do Campo, v. 6, t. 1, p. 276, 2000.
} 
sistema recursal. ${ }^{213}$ Com efeito, ainda que os mesmos não estejam expressos no ordenamento normativo, são de extrema relevância no âmbito recursal.

Numerosos são os princípios descritos pela doutrina como afetos ao âmbito recursal $^{214}$. Ressalvamos que não pretendemos no presente estudo esgotá-los, e optamos por fazer neste capítulo um apanhado geral sobre o tema, buscando compatibilizar os princípios recursais com as inovações inseridas pelo art. 285-A do CPC.

\subsection{Do cabimento dos embargos de declaração}

De acordo com o art. 535 do CPC, os embargos de declaração são o meio processual concedido à parte para obter esclarecimento da decisão obscura, contraditória ou omissa.

Questiona-se no meio doutrinário a natureza dos embargos declaratórios, se seria um mero incidente de julgamento ou ainda um mero mecanismo de elucidação do julgado $^{215}$. Dentre os argumentos utilizados para se afastar a natureza de recurso dos embargos de declaração costuma-se apontar a ausência de efeito devolutivo, a ausência de contraditório, inexistência de preparo e, ainda, a possibilidade de serem opostos pela parte não sucumbente.

Filiamo-nos, contudo, à corrente que entende que constituem os embargos de declaração uma espécie de recurso, estando em consonância com o princípio da taxatividade, encontrando guarida no Código de Processo Civil, em seus arts. 496, IV, e 535, I e II. Ademais, os embargos de declaração visam reparar eventual defeito do julgado, tais como a obscuridade, a contradição ou a omissão de que o mesmo se ressente. ${ }^{216}$

\footnotetext{
${ }^{213}$ Conforme enfatiza Flávio Cheim, "somente através da identificação e compreensão dos princípios - como elementos estruturantes de um sistema - é que podemos conceber e qualificar uma série de características próprias de todos os recursos”. (JORGE, Flávio Cheim. Teoria geral dos recursos cíveis. 5. ed. São Paulo: Ed. Revista dos Tribunais, 2011. p. 216).

${ }^{214}$ Acerca do tema, remetemos o leitor à obra de Nelson Nery Júnior, Princípios fundamentais: teoria geral dos recursos. São Paulo: Ed. Revista dos Tribunais, 1997.

${ }^{215}$ Nesse sentido, aduz Sérgio Bermudes que: "não se trata de um recurso, embora o art. 496 do código os inclua entre as espécies recursais, no seu inciso IV. Cuida-se, na verdade, de um incidente destinado ao aperfeiçoamento da fórmula pela qual a decisão se materializou”. (BERMUDES, Sérgio. Introdução ao processo civil. Rio de Janeiro: Forense, 1995. p. 160).

${ }^{216} \mathrm{Na}$ mesma esteira, destacamos: "Considerando que os embargos de declaração, que devem ser dirigidos a juiz (primeiro grau) ou ao relator do acórdão (tribunal), não visam, em tese, à modificação do julgado, parte da doutrina tem negado a sua natureza recursal. Porém, como os embargos de declaração estão, de forma taxativa, arrolados dentro do sistema recursal do CPC, aliás como sempre ocorreu tradicionalmente
} 
No que diz respeito aos argumentos acima ventilados contra a sua natureza recursal, temos para nós que os mesmos não são suficientes para extirpar dos embargos de declaração tal natureza. Senão vejamos.

Em que pese seja comum a exigência de preparo aos recursos, a dispensa estabelecida no art. 536, do CPC, em nada interfere na natureza do remédio, tal qual ocorre também com relação à dispensa o recolhimento do preparo na hipótese do agravo retido (art. 522, § único, do CPC).

Igualmente, a possibilidade dos embargos de declaração serem apresentados por quaisquer das partes não interfere no seu caráter recursal, já que o vício contido no julgado prejudica a ambas as partes, uma vez que mesmo a parte vitoriosa não terá alcançado tudo aquilo que poderia estar no julgado, em razão da existência de obscuridade, contradição ou omissão.

No que diz respeito ao contraditório, se a alteração em nada prejudica a parte contrária, o mesmo pode ser considerado desnecessário ou, ainda, impertinente, por somente trazer maior delonga ao processo.

Deve-se frisar também que o efeito devolutivo é resultado da interposição ou oposição de todo e qualquer recurso, ainda que destinado ao mesmo órgão jurisdicional prolator da decisão recorrida, como sucede nos embargos declaratórios.

A doutrina aponta que os embargos declaratórios têm origem lusitana. Estiveram presentes nas ordenações Afonsinas, Manoelinas e também nas ordenações Filipinas. Convém anotar seu ingresso em nosso sistema por intermédio do regulamento 737 , de 1850 (arts. 639 e 641 a 643), bem como sua previsão na Consolidação Ribas (arts. 495, 496 e 1.499 e ss.), sendo que nas duas normas havia prazo de dez dias para sua oposição. Temos, ainda, sua presença no Código de Processo Civil de 1939, no chamado livro "Dos Recursos". ${ }^{217}$

Ressalte-se também que a divergência inicialmente existente no Código de Processo Civil de 1973 com relação ao prazo para oposição do recurso de embargos, 48

no Brasil, a posição contrária acaba enfraquecida, porquanto a natureza do recurso encampa uma opção da lei. Dentro dessa esteira, o CPC é expresso quanto à natureza recursal dos embargos de declaração, ex vi do dispositivo em comento. $O$ entendimento acerca da natureza recursal dos embargos de declaração, aliás, é hoje adotado prevalentemente pela doutrina”. (MIRANDA, Gilson Delgado. Dos embargos de declaração. In: MARCATO, Antonio Carlos (Coord.). Código de Processo Civil interpretado. São Paulo: Atlas, 2004. p. 1592).

${ }^{217}$ BONDIOLI, Luís Guilherme Aidar. Os embargos declaratórios sob a ótica da efetividade. Dissertação (Mestrado) - Faculdade de Direito, Universidade de São Paulo, São Pualo, 2004. p. 19. 
horas e 5 dias, foi erradicada com o advento da Lei n. 8.950/94, que unificou em 5 (cinco) dias o prazo para apresentação dos embargos de declaração em primeiro e segundo grau de jurisdição.

Cabe salientar que os embargos declaratórios são recursos de fundamentação vinculada que, segundo Nelson Nery Júnior e Rosa Maria Nery, "têm finalidade de completar a decisão omissa ou, ainda, de aclará-la, dissipando obscuridades ou contradições". Lembram, ainda, os citados autores que este recurso "não tem caráter substitutivo da decisão embargada, mas sim integrativo ou aclaratório”. ${ }^{218}$

Acerca dos vícios que podem justificar a utilização dos embargos declaratórios, temos que a obscuridade decorre da ausência de compreensão total ou parcial de determinado capítulo ou ideia do julgado. Decorre, assim, da falta de clareza da decisão (seja pela sua imprecisão ou utilização de locução inapropriada), o que dificulta ter-se a sua adequada inteligência ou apropriada interpretação.

A contradição, por seu turno, sucede quando o julgado possui afirmações ou conclusões que se mostram entre si inconciliáveis. Ressalte-se que a contradição pode acontecer entre proposições contidas na motivação, na parte decisória, ou, ainda, entre a ementa e o corpo do acórdão.

No que diz respeito à omissão, temos que se trata da hipótese em que o julgador deixa de analisar questões levantadas no curso do processo. Em outras palavras, refere-se à falta de pronunciamento judicial sobre determinado ponto relevante suscitado pelas partes, o que não se confunde com fundamentos que servem de base fática, lógica para a questão ou ponto, e sobre os quais o magistrado não está obrigado a fazer expressa menção. Nesse sentido, convém destacar que motivação sucinta não se confunde com ausência de motivação, apta a ensejar a oposição dos embargos de declaração. ${ }^{219}$

Insta salientar que com a reforma do Código de Processo Civil pela Lei n. 8.950/1994, suprimiu-se a possibilidade de oposição de embargos de declaração tendo por fundamento a existência de dúvida, sendo que tal requisito se manteve apenas para os

\footnotetext{
${ }^{218}$ NERY JÚNIOR, Nelson; NERY, Rosa Maria Andrade. Código de Processo Civil comentado e legislação processual civil extravagante em vigor, cit., p. 945.

${ }^{219}$ Tem a jurisprudência considerado como omissão a falta de apreciação de pedido de desistência ou renúncia ao direito, manifestado antes do julgamento da causa, bem como o silêncio quanto à verba para honorários pleiteada pelo vencedor. (Cf. TRF $3^{\mathrm{a}}$ Região, QUARTA TURMA, AMS 0039628-78.1998.4.03.6100, Rel. JUIZ CONVOCADO DAVID DINIZ, julgado em 03/05/2012, e-DJF3 Judicial 1 DATA:29/05/2012; STJ, EDcl no REsp 1091744/SP, Rel. Ministro MARCO BUZZI, QUARTA TURMA, julgado em 28/08/2012, DJe 04/09/2012; STJ, EDcl na AR 3.013/RS, Rel. Ministro HUMBERTO MARTINS, PRIMEIRA SEÇÃO, julgado em 28/09/2011, DJe 06/10/2011).
} 
embargos declaratórios a serem opostos nos Juizados Especiais Cíveis, a teor do que dispõe o art. 48, caput, da Lei 9.099/1995.

Em regra, os embargos de declaração não têm caráter substitutivo, modificativo ou infringente da decisão embargada, mas sim integrativo ou aclaratório. Contudo, em alguns casos pode ocorrer que ao suprir uma omissão, eliminar uma contradição ou esclarecer uma obscuridade surja a necessidade de alteração do conteúdo da decisão embargada. Nesse sentido, pode ocorrer de, em casos especiais e em caráter excepcional, ser necessário atribuir aos embargos efeito infringente, isto é, um efeito modificativo.

Em que pese inexista a necessidade de intimação da parte contrária para apresentação de contrarrazões nos embargos de declaração, tem-se de bom tom, sempre que se perceber a probabilidade de produção de efeitos infringentes, determinar a intimação da parte contrária para manifestação, em respeito à garantia constitucional do contraditório e da ampla defesa. ${ }^{220} \mathrm{O}$ projeto do novo CPC, em seu art. 976, parágrafo único, prevê textualmente que "eventual efeito modificativo dos embargos de declaração somente poderá ocorrer em virtude da correção do vício, desde que ouvida a parte contrária no prazo de cinco dias”.

Na legislação pátria, como já noticiamos, os embargos declaratórios têm cabimento nas hipóteses versadas no art. 535 do CPC. Oportuna indagação refere-se à possibilidade de utilização dos embargos para ver-se corrigido eventuais erros materiais do julgado. Nos termos do art. 463, do CPC os erros materiais podem ser corrigidos de ofício ou a

\footnotetext{
${ }^{220}$ Quem defende expressamente essa ideia é Gilson Delgado Miranda, que assim se pronuncia sobre o tema: "A par do afastamento do contraditório na grande maioria dos casos, o fato é que só se pode admitir conduta desse jaez em se tratando de embargos de declaração sem efeitos modificativos ou infringentes. Assim, divorciando-se da natureza usual do recurso, caso se postule a modificação do julgado, em homenagem ao princípio constitucional insculpido no art. $5^{\circ}, \mathrm{LV}$, da CF, deverá o juiz ou relator, conforme o caso, abrir a possibilidade de a parte contrária se manifestar. Do contrário, cerceado o direito da parte, a atuação jurisdicional estará em desconformidade com o princípio fundamental indicado, passível, assim, de acertamento pela via recursal própria”. (MIRANDA, Gilson Delgado. Dos embargos de declaração, cit., p. 1596). Nesse sentido, ainda, confira-se: “AGRAVO REGIMENTAL EM AGRAVO EM RECURSO ESPECIAL. EMBARGOS DE DECLARAÇÃO. EFEITOS INFRINGENTES. AUSÊNCIA DE INTIMAÇÃO DA PARTE CONTRÁRIA. VÍCIO INSANÁVEL. NULIDADE. PRECEDENTES. 1. O Superior Tribunal de Justiça tem entendimento firmado no sentido de que a atribuição de efeitos infringentes aos embargos de declaração supõe a prévia intimação da contraparte, visto que, sem o contraditório, o respectivo julgamento é nulo. 2. Os argumentos expendidos nas razões do regimental são insuficientes para autorizar a reforma da decisão agravada, de modo que esta merece ser mantida por seus próprios fundamentos. 3. Agravo regimental não provido”. (AgRg no AREsp 195.344/RJ, Rel. Ministro RICARDO VILLAS BÔAS CUEVA, TERCEIRA TURMA, julgado em 18/10/2012, DJe 25/10/2012) - grifos nossos.
} 
requerimento das partes, sendo que por construção pretoriana, integrativa, tem se admitido o emprego dos embargos de declaração. ${ }^{221}$

Da análise sistemática do Código conclui-se que todos os pronunciamentos judiciais devem ser claros a fim de não gerar insegurança aos jurisdicionados ou, ainda, dificultar o seu cumprimento na prática. Nesse sentido, admite-se, inclusive o cabimento de embargos de declaração em face de despachos ${ }^{222}$ e de decisões proferidas no julgamento de embargos de declaração, já que também estas não estão imunes a defeitos.

A Lei n. ${ }^{\circ}$ 8.950/94 trouxe ainda outras duas inovações no que diz respeito aos embargos declaratórios. No caput do art. 538, do CPC encontra-se expresso que a apresentação de embargos de declaração interrompe o prazo para a interposição de outros recursos, por ambas as partes. Assim, após a intimação das partes acerca da sentença dos embargos de declaração, retorna-se a contagem do lapso temporal na íntegra para ambas as partes. ${ }^{223}$ Referida novidade, contudo, não veio sozinha. Isto porque o parágrafo único do art. 538, do CPC trouxe previsão de condenação de multa para os casos em que os embargos de declaração forem empregados com fito de protelar o feito.

Questionamento oportuno refere-se ao cabimento de embargos declaratórios em face da sentença prévia de improcedência proferida com fulcro no art. 285-A do CPC, tendo em vista o silêncio do dispositivo. Com efeito, regra geral, o conteúdo decisório definitivo e conclusivo da lide comporta ser esclarecido pela via dos embargos de declaração, sendo que não faria qualquer sentido excluir a sentença de improcedência com fundamento no art. 285-A do rol de situações embargáveis.

\footnotetext{
${ }^{221}$ Cf. "PREVIDENCIARIO. PROCESSO CIVIL. EMBARGOS DE DECLARAÇÃO. OMISSÃO. REQUISTOS PARA CONCESSÃO DE APOSENTADORIA POR INVALIDEZ. I - O objetivo dos embargos de declaração, de acordo com o art. 535 do Código de Processo Civil, é sanar eventual obscuridade, contradição ou omissão e, ainda, conforme o entendimento jurisprudencial, a ocorrência de erro material no julgado. (...) IV - Embargos de declaração opostos pelo INSS rejeitados". (TRF $3^{\mathrm{a}}$ Região, DÉCIMA TURMA, AC 0007803-68.2012.4.03.9999, Rel. DESEMBARGADOR FEDERAL SERGIO NASCIMENTO, julgado em 16/10/2012, e-DJF3 Judicial 1 DATA: 24/10/2012).

${ }^{222}$ Nesse sentido: "Tendo em vista que o despacho integra o rol de atos em que se consubstancia a prestação jurisdicional e que existe o interesse no bom desempenho da atividade do Estado-Juiz como um todo, não há como exclui-lo das hipóteses dos embargos". BONDIOLI, Luís Guilherme Aidar. Os embargos declaratórios sob a ótica da efetividade, cit., p. 77. Em sentido semelhante, acrescenta Araken de Assis que o fato de os despachos não provocarem gravame às partes não os libera dos defeitos previstos no art. 535 do CPC, motivo pelo qual também em face deles são cabíveis os embargos de declaração. (ASSIS, Araken de. Manual dos recursos. São Paulo: Ed. Revista dos Tribunais, 2007. p. 56).

${ }^{223}$ Calha ressalvar que a lei dos Juizados Especiais Cíveis, em seu artigo 50, mantém a opção pela suspensão do prazo ("Quando interposto contra sentença, os embargos de declaração suspenderão o prazo para recurso”).
} 
É injustificável recusar a utilização de embargos de declaração contra as sentenças de improcedência prima facie. No tocante a sua utilização pelo autor, não há, inicialmente, grandes dilemas. O autor somente deverá se utilizar dos embargos de declaração caso vislumbre a presença de algum dos requisitos dispostos no art. 535 do CPC acima abordados, observando o prazo legal de 05 dias.

O julgamento dos embargos declaratórios comporta as mesmas fases do julgamento de qualquer recurso, havendo, num primeiro momento, a análise pelo conhecimento ou não dos embargos e, num segundo momento, se conhecido, passa o magistrado a analisar se lhe dá ou não provimento.

Problema surge quando o embargante pleiteia a reforma do provimento embargado, postulando o chamado efeito infringente, uma vez que, nessas hipóteses, entendendo o magistrado pela procedência do pedido, conforme acima mencionado, necessário se faz a intimação do réu para se manifestar nos autos.

No tocante à utilização dos embargos de declaração pelo réu, mister fazer alguns esclarecimentos. Isto porque o réu somente tem ciência do julgado após a apelação do autor, quando intimado para apresentar contrarrazões. A respeito desse tema, compartilhamos do entendimento que preconiza que o ideal é que se tolere a oposição dos embargos de declaração pelo réu tão logo seja o mesmo intimado para oferecer resposta ao recurso do autor e tome conhecimento da sentença omissa, obscura ou contraditória. Isto porque, tal conduta permitirá “sanar o defeito ainda no primeiro grau de jurisdição e, somente após, remeter o processo ao tribunal hierarquicamente superior”. ${ }^{224}$

Frise-se, por fim, que tendo em vista que como é sabido os embargos de declaração interrompem o prazo para interposição de outros recursos, e que esse efeito perdura até a publicação da decisão impugnada (nos termos do artigo 538, do CPC), somente após a intimação da decisão que julgar os embargos é que se iniciará a contagem do novo prazo para interposição de eventual recurso de apelação.

Todavia, mostra-se desnecessário, em nosso sentir, a ratificação do apelo já interposto pela parte autora após o julgamento desses aclaratórios, quando as matérias

\footnotetext{
${ }^{224}$ POITTEVIN, Ana Laura González. O art. 285-A do CPC e os embargos de declaração, cit., p. 622-623.
} 
discutidas nos dois recursos forem distintas, sob pena de apego demasiado ao formalismo, o que não se coaduna com o objetivo do direito processual contemporâneo. ${ }^{225}$

\subsection{Do recurso adequado diante do julgamento de improcedência de plano e o princípio da fungibilidade recursal}

Em regra, além do interesse do legitimado em impugnar o ato decisório, há necessidade de utilização do instrumento recursal adequado para tal. Com efeito, deixando a parte de usar o recurso disposto em lei para a hipótese impugnada, este deixará de ser recebido pela ausência de um dos requisitos de admissibilidade.

De acordo com o princípio da unirrecorribilidade ou unicidade recursal, para cada ato judicial há uma única espécie recursal, sendo vedada a interposição cumulada e/ou simultânea de mais de um recurso para um mesmo provimento jurisdicional.

O princípio em comento possui relação com o pressuposto da adequação, e quer dizer que só se pode utilizar de um recurso de cada vez. Faz-se importante esclarecer que isto não obsta a possibilidade das partes interporem cada uma um recurso da mesma decisão, na hipótese de haver sucumbência recíproca. ${ }^{226}$

Embora o CPC atual não repita regra idêntica ao artigo 809 do Estatuto processual de 1939, a qual previa que a parte não poderia se utilizar, ao mesmo tempo, de mais de um recurso, nem por isso deixa de ter validade o princípio da singularidade. ${ }^{227}$

Diante da vedação trazida pelo princípio unicidade recursal de interposição cumulada e/ou simultânea de mais de um recurso para uma mesma decisão judicial,

\footnotetext{
${ }^{225}$ Vale dizer que, neste ponto, ousamos discordar do posicionamento adotado pelo Egrégio STJ (a título exemplificativo, ver AgRg no REsp 1287905/PR, Rel. Ministro LUIS FELIPE SALOMÃO, QUARTA TURMA, julgado em 23/10/2012, DJe 07/11/2012), no sentido de que em sendo a apelação apresentada antes da publicação do resultado dos embargos de declaração contra a sentença, isto é, antes de encerrada a prestação jurisdicional no primeiro grau, seria a mesma prematura, sendo necessária a ratificação posterior dos seus termos.

${ }^{226}$ Cf. MIRANDA, Gilson Delgado; PIZZOL, Patricia Miranda. Processo civil: recursos. 5. ed. São Paulo: Atlas, 2006. v. 1, p. 9.

${ }^{227}$ Nesse sentido: "apesar de não restar atualmente expresso, como no CPC antigo, sua presença é implacável e inevitável no CPC atual, e isso se dessume da aplicação sistemática do art. 496 (taxatividade) somada com a co-relatividade do art. 162 e dos arts. 504, 513 e 522, que, ao estabelecerem os atos decisórios do juiz e co-relacionarem tais atos com seu respectivo recurso, acabaram por prever o referido princípio no sistema”. (Cf. RODRIGUES, Marcelo Abelha. Manual de direito processual: teoria geral: premissas e institutos fundamentais, relação jurídica; procedimentos em $1^{\circ}$ e $2^{\circ}$ graus; recursos; execução; tutela de urgência. 4. ed. reform., atual. e ampl. São Paulo: Ed. Revista dos Tribunais, 2008. p. 514).
} 
questão que surge é como proceder nos casos em que certas situações peculiares trazem dúvidas ao coração do recorrente a cerca do recurso adequado à espécie.

A ideia da fungibilidade recursal traduz a possibilidade de substituição de um recurso interposto inadequadamente pelo que seria o correto para se recorrer de determinada decisão judicial.

Este princípio tinha previsão expressa no art. 810, do CPC de 1939 e dizia o seguinte: "Salvo a hipótese de má-fé ou erro grosseiro, a parte não será prejudicada pela interposição de um recurso por outro, devendo os autos ser enviados à Câmara, ou Turma, a que competir o julgamento".

O Código de Processo Civil vigente não contempla nenhum artigo específico sobre a fungibilidade recursal. A justificativa para tanto, segundo aponta a doutrina, seria que " $o$ nosso CPC/73 introduziu um sistema recursal flagrantemente simples, afastando a possibilidade de erro no momento da interposição do recurso". 228

Apesar da falta de previsão legal acerca da fungibilidade recursal, vem-se admitindo sua aplicação, entendendo tratar-se de um princípio jurídico implícito, que merece acolhida ante a complexidade das relações que acometem o direito. De fato, logo se constatou que o princípio da fungibilidade não era desnecessário ou supérfluo, uma vez que ainda hoje há "dúvidas, expressadas na doutrina e refletidas na jurisprudência discrepante, a respeito de qual seria o recurso adequado a esta ou aquela situação”. ${ }^{229}$

Um dos argumentos favoráveis ao cabimento da fungibilidade recursal é que tal princípio “decorre de postulado maior, que é o princípio da instrumentalidade das formas, estatuído expressamente no art. 250 do CPC”. ${ }^{230}$

A aplicação do princípio da fungibilidade em matéria recursal está adstrita ao preenchimento de alguns requisitos.

\footnotetext{
${ }^{228}$ Cf. MIRANDA, Gilson Delgado; PIZZOL, Patricia Miranda. Processo civil: recursos, cit., v. 1, p. 12.

${ }^{229}$ WAMBIER, Teresa Arruda Alvim. O óbvio que não se vê: a nova forma do princípio da fungibilidade. Migalhas, n. 1437, $2006 . \quad$ Disponível em: <http://www.migalhas.com.br/mostra_noticia_articuladas.aspx?cod=25047> Acesso em: 13 de maio de 2010. ${ }^{230}$ NERY JÚNIOR, Nelson. Princípios fundamentais: teoria geral dos recursos, cit., p. 146.
} 


\section{A) Dúvida fundada a respeito do recurso cabível}

O primeiro requisito diz respeito à dúvida objetiva em relação ao recurso cabível diante de determinado pronunciamento judicial. Isto ocorre, em regra, em virtude da existência de divergências doutrinárias e jurisprudenciais acerca do cabimento de um ou de outro recurso.

Preciso o ensinamento de Luís Otávio Sequeira de Cerqueira para o qual a locução dúvida objetiva "corresponde a uma dúvida efetiva, imparcial, existente não só no juízo de quem está em dúvida quanto ao meio mais adequado a utilizar, mas também na doutrina e na jurisprudência”. ${ }^{231}$

Assim, deve existir dúvida efetiva quanto ao tipo de recurso que deve ser aceito diante de determinado pronunciamento, haja vista a existência de entendimento doutrinário e jurisprudencial em sentidos diversos, ora apontando para um recurso ora para outro. É de se ressaltar que a dúvida apta a ensejar a aplicação do princípio em comento não é aquela meramente subjetiva. ${ }^{232}$

De acordo com Nelson Nery Júnior são de três ordens as dúvidas fundadas. A primeira, ocorre quando o próprio ordenamento de forma imprópria ou confusa assinala uma decisão interlocutória como sentença ou, ao contrário, nomeia uma sentença como decisão interlocutória. A segunda, por sua vez, se dá quando há discrepância no que diz respeito à inclusão de determinado ato jurisdicional numa determinada categoria pela doutrina e/ou jurisprudência, o que, por conseguinte não traz consenso quanto ao meio adequado para atacá-lo. Por fim, pode haver dúvida fundada quando o magistrado dá um pronunciamento ao invés de outro esperado. ${ }^{233}$

Luiz Orione Neto entende que apenas o segundo item elencado por Nelson Nery é capaz de configurar a dúvida objetiva e permitir a aplicação da fungibilidade recursal, já que não basta mera previsão em lei de uma decisão interlocutória como sentença ou viceversa para a incidência do princípio. Argumenta que esta previsão legal "só terá alguma

\footnotetext{
${ }^{231}$ CERQUEIRA, Luís Otávio Sequeira de. O princípio da fungibilidade e os poderes do juiz. In: MEDINA, José Miguel Garcia et al (Coord.). Os poderes do juiz e o controle das decisões judiciais: estudos em homenagem à Professora Teresa Arruda Alvim Wambier. São Paulo: Ed. Revista dos Tribunais, 2008. p. 311.

${ }^{232}$ A melhor doutrina afirma que: "dúvida desprovida de controvérsia externa, ou dados objetivos extraídos da lei, e que contamina o espírito do recorrente no ato da interposição, constitui simples erro e, nessas condições, não tem força suficiente para revelar o juízo de admissibilidade a que tem direito o recorrido." (ASSIS, Araken de. Manual dos recursos, cit., p. 87).

${ }^{233}$ NERY JÚNIOR, Nelson. Princípios fundamentais: teoria geral dos recursos, cit., p. 116.
} 
relevância se a impropriedade legislativa tiver o condão de causar perplexidade na doutrina e na jurisprudência”. ${ }^{234}$

Por oportuno, ressalte-se que para que se legitime o emprego do princípio, a dúvida há de ser atual, isto é, que não tenha sido superada pela doutrina e jurisprudência.

\section{B) Inexistência de erro grosseiro}

O erro grosseiro se apresenta quando há a interposição de um recurso por outro contrariando expressa disposição legal ou quando a situação não apresenta dúvida alguma. ${ }^{235}$ Por outro lado, o erro é escusável quando silente a lei, doutrina e jurisprudência divergem acerca do recurso cabível para impugnar um determinado pronunciamento.

Assim, inexistindo no caso em concreto a presença da chamada dúvida objetiva, em virtude da uniformidade doutrinária e jurisprudencial sobre qual seria o recurso próprio, não é possível aplicar-se a fungibilidade. ${ }^{236}$

\section{C) Inexistência de má-fé}

A má-fé era requisito negativo de aplicação do princípio da fungibilidade no sistema do direito anterior. Diante da dificuldade em sua aferição, buscou-se subsídio em um critério objetivo, o prazo. Assim, “prevalecia o entendimento de que o recurso interposto erroneamente deveria havê-lo sido dentro do prazo do recurso próprio, ou, por outra, no prazo 'menor', para que se pudesse aplicar o princípio da fungibilidade (art. 810, CPC/39)". 237

\footnotetext{
${ }^{234}$ ORIONE NETO, Luiz. Recursos cíveis: teoria geral, princípios fundamentais, dos recursos em espécie, tutela de urgência no âmbito recursal, da ordem dos processos no tribunal, cit., p. 181.

${ }^{235}$ Nelson Nery Jr. refletindo sobre o assunto conclui que "em se tratando de erro grosseiro, não é possível aplicar-se a fungibilidade, pois não seria razoável premiar-se o recorrente desidioso, que age em desconformidade com as regras comezinhas do direito processual. Ao revés, se o erro for escusável, não se caracterizando como grosseiro, a regra tem incidência plena". (NERY JÚNIOR, Nelson. Princípios fundamentais: teoria geral dos recursos, cit., p. 137).

${ }^{236}$ O STJ já teve possibilidade de se manifestar neste exato sentido: "PROCESSUAL CIVIL. AGRAVO DE INSTRUMENTO CONTRA DECISÃO QUE NÃO CONHECEU DO RECURSO ESPECIAL. NÃO CABIMENTO. ERRO GROSSEIRO. PRINCÍPIOS DA INSTRUMENTALIDADE DAS FORMAS E FUNGIBILIDADE RECURSAL. INAPLICABILIDADE. (...)2. "A interposição de Agravo de Instrumento ao invés de Agravo Regimental impede a incidência do princípio da fungibilidade, posto dilargar o prazo do recurso corretamente cabivel, além de configurar erro inescusável" (Ag no REsp 1328220/RJ, Rel. Ministro MAURO CAMPBELL MARQUES, SEGUNDA TURMA, julgado em 06/09/2012, DJe 14/09/2012).

${ }^{237}$ Cf. NERY JÚNIOR, Nelson. Princípios fundamentais: teoria geral dos recursos, cit., p. 137.
} 
A maioria da jurisprudência ao analisar esse requisito, hoje, o faz também a partir da teoria do prazo menor. ${ }^{238}$ A doutrina, em posição antagônica ao entendimento dos tribunais, sustenta que é irrelevante o recorrente ter se utilizado de prazo maior entre os recursos cabíveis, sendo que o mesmo deve observar apenas o prazo do recurso efetivamente interposto, pois foi o tido como adequado pela parte.

Araken de Assis a respeito da tese de que deve ser observado o prazo do recurso próprio assevera que tal "exigência representa flagrante excesso e, na prática, impede a troca na sua plenitude”. 239

Refuta-se a subsistência da inexistência de má-fé como fundamento para a aplicação do princípio da fungibilidade sob o argumento que "havendo os pressupostos para aferição da dúvida objetiva, ou, da inexistência do erro grosseiro, o prazo se nos afigura absolutamente irrelevante”. ${ }^{240}$

Tal exigência não se coaduna com o propósito do instituto, já que uma vez presente dúvida objetiva a respeito do recurso cabível, evidentemente também haverá dúvida com relação ao prazo de sua interposição, daí ser desnecessário o pressuposto do prazo menor como condição para aplicação do princípio em comento. ${ }^{241}$

\footnotetext{
${ }^{238}$ Nesse sentido, destacamos: "PROCESSUAL CIVIL. EMBARGOS DE DIVERGENNCIA. EMBARGOS À EXECUÇÃO. EXTINÇÃO. APELAÇÃO. INTERPOSTO AGRAVO DE INSTRUMENTO. ERRO GROSSEIRO. INOCORRÊNCIA. PRINCÍPIO DA FUNGIBILIDADE. CABIMENTO. PRECEDENTES. 1. Agravo de instrumento interposto contra decisão que extinguiu embargos à execução. Recurso incorretamente proposto porquanto o adequado seria a apelação. Inexistência de erro grosseiro ou má-fé. Fungibilidade. 2. O defeito de forma só deve acarretar a anulação do ato processual impassível de ser aproveitado (art. 250 do CPC) e que, em princípio, cause prejuízo à defesa dos interesses das partes ou sacrifique os fins de justiça do processo. Consagração da máxima pas des nullité sans grief. 3. Por força da influência do "princípio da instrumentalidade das formas", tem-se admitido, no campo da inadequação recursal, a aplicação do vetusto princípio da fungibilidade dos recursos, cuja incidência permite o aproveitamento do recurso interposto como se fosse o meio de impugnação cabivel e não utilizado. Fundando-se em ordenação pretérita, a jurisprudência consagrou essa possibilidade, desde que "ausente o erro grosseiro" e a "má-fé do recorrente". 4 . Um dos critérios utilizados tem sido a escorreita verificação da tempestividade; por isso, um recurso com prazo de interposição menor é admissível se interposto no lugar daquele cabível, cujo prazo de oferecimento é mais alongado. A recíproca, contudo, não é verdadeira. 5. Revela malícia do recorrente aproveitar-se de recurso com maior devolutividade e procedimento mais delongado, circunstância inocorrente na hipótese. 6. Precedentes da Corte. 7. Embargos de divergência conhecidos e desprovidos". (EREsp 197.857/RJ, Rel. Ministro PAULO MEDINA, Rel. p/ Acórdão Ministro LUIZ FUX, PRIMEIRA SEÇÃO, julgado em 23/10/2002, DJ 16/12/2002, p. 235). - grifos nossos. Confira-se, ainda: EDcl no REsp 464.425/SP, Rel. Ministro CASTRO FILHO, TERCEIRA TURMA, julgado em 10/08/2006, DJ 11/09/2006, p. 246.

${ }^{239}$ ASSIS, Araken de. Manual dos recursos, cit., p. 93.

${ }^{240}$ Cf. NERY JÚNIOR, Nelson. Princípios fundamentais: teoria geral dos recursos, cit., p. 138.

${ }^{241} \mathrm{Na}$ mesma linha: ORIONE NETO, Luiz. Recursos cíveis: teoria geral, princípios fundamentais, dos recursos em espécie, tutela de urgência no âmbito recursal, da ordem dos processos no tribunal, cit., p. 176177. Também do mesmo sentir: CERQUEIRA, Luís Otávio Sequeira de. O princípio da fungibilidade e os poderes do juiz, cit., p. 312.
} 
Nelson Nery crê ser desarrazoado exigir que a parte recorra no prazo do recurso que deveria ser interposto (o correto), sob os seguintes fundamentos:

\begin{abstract}
a)isto configuraria imputar-se-lhe, presumivelmente, a má-fé, quando o contrário é que seria verdadeiro (a presunção é a da boa-fé); b)em assim agindo, estar-se-ia, em última análise, negando a existência do princípio da fungibilidade; c)esta atitude caracteriza ofensa ao direito constitucional do devido processo legal, pois que se estaria subtraindo do recorrente o direito, que pelas regras processuais ele possui, de, por exemplo, interpor o recurso de apelação em quinze dias. ${ }^{242}$
\end{abstract}

Como já asseverado, do provimento jurisdicional que julga o pedido totalmente improcedente com fulcro no art. 285-A o recurso cabível é o de apelação (art. 162, § $1^{\circ}$, c/c os arts. 269, I e 513 do CPC), não comportando maiores divagações.

Todavia, retornando ao tema tratado anteriormente acerca da possibilidade de cisão do momento do julgamento nas hipóteses de cumulação de pedidos autônomos entre si, resta averiguar o recurso pertinente, daí a utilidade da breve digressão acerca da fungibilidade recursal.

O Código de Processo Civil, ao permitir em seu artigo 505 a impugnação parcial da sentença, admite o fracionamento da decisão judicial, e isso somente é razoável porque se conhece a possibilidade de cisão do julgado em capítulos.

Com efeito, sempre que numa mesma causa houver a reunião de pretensões diversas, com existência própria, ainda que não autônomas, cada uma delas constituíra um capítulo. Deste modo, o pronunciamento do magistrado acerca de cada um dos pedidos constituirá os capítulos de sentença.

A doutrina majoritária compreende a possibilidade de cindir a sentença em capítulos, de acordo com os pedidos processuais ou materiais. ${ }^{243}$ Nessa toada, se o pedido ou, sendo uma demanda complexa, todos os pedidos comportarem o julgamento de improcedência, com a incidência do art. 285-A, maiores digressões não são necessárias, já que com fundamento no $\S 1^{\circ}$ do art. 285-A do CPC o recurso cabível será o de apelação.

Aqui, cabe salientar que nos moldes do art. 505 do CPC a sentença poderá ser impugnada no todo (isto é, o recurso será integral, versando sobre todos os capítulos da

\footnotetext{
${ }^{242}$ NERY JÚNIOR, Nelson. Princípios fundamentais: teoria geral dos recursos, cit., p. 145.

${ }^{243}$ Cf. LIEBMAN, Enrico Tulio. Parte o "capo" di sentenza. Revista di Diritto Processuale Civile, Padova, $\mathrm{n}$. 5, p. 56, 1964. MARQUES, José Frederico. Manual de direito processual civil. Campinas: Bookseller, 1997. v. 3, p. 66.
} 
decisão) ou em parte (também chamado recurso parcial, versando apenas sobre um ou alguns dos capítulos da sentença). O capítulo de sentença proferida com base no art. 285-A não impugnado transitará em julgado formal e materialmente, sendo que sobre ele nenhum efeito produzirá o julgamento do recurso.

Dúvida que surge, e da qual já nos ocupamos no presente trabalho, é sobre a possibilidade de cindir o momento da emissão do pronunciamento judicial. Em outras palavras, questiona-se se estando apenas parcela do processo madura para julgamento, poderia o magistrado julgar imediatamente tais pedidos com fulcro no art. 285-A e determinar o normal prosseguimento da outra parcela.

Com efeito, no capítulo anterior, concluímos que apesar de não ser o comportamento mais adequado, tal solução é admissível em nosso ordenamento. E, assim sendo, ali destacamos que há divergências na doutrina sobre a natureza de tal pronunciamento, se sentença ou, ainda, decisão interlocutória. Resta-nos, agora, refletir a respeito do recurso cabível para atacar tal pronunciamento judicial parcial.

Teresa Arruda Alvim Wambier e Luiz Rodrigues Wambier tecem os seguintes comentários a respeito do tema:

Muitos têm dito que, havendo dois pedidos, o juiz pode decidir apenas um deles com base no 285-A e mandar citar o réu para o outro.

E o recurso que cabe desta sentença nascida precocemente? Qual seria? Segundo alguns, seria o recurso de agravo, e aí se estaria diante de mais uma exceção ao princípio da congruência!

Isto porque se trata de uma sentença, ou seja, de uma decisão cujo conteúdo é encartável no art. 269 do CPC (embora não ponha fim ao procedimento como um todo, já que resta um pedido a ser decidido). Mas, por razões de ordem pragmática, ligadas à operatividade do procedimento, seria agravável e não apelável.

Outros argumentam inteligentemente, dizendo que o recurso adequado seria a apelação, já que ofenderia o princípio da isonomia proporcionar às partes o uso de dois recursos diferentes manejáveis contra decisões da mesma categoria. Afinal, a apelação tem revisão e possibilita que as partes sustentem oralmente. Mas a apelação teria de ser "por instrumento", pois o processo não poderia parar. ${ }^{244}$

\footnotetext{
${ }^{244}$ WAMBIER, Teresa Arruda Alvim e WAMBIER, Luiz Rodrigues. Anotações sobre o julgamento de processos repetitivos. Disponível em: <http://www.buscalegis.ufsc.br/revistas/index.php/buscalegis/article/view/9879/9445>. Acesso em: 13 de jun. de 2010.
} 
Nelson Nery Júnior e Rosa Maria Andrade Nery defendem a possibilidade do julgamento cindido, atribuindo natureza de decisão interlocutória a tal pronunciamento judicial. No tocante ao recurso, salientam que o adequado seria o agravo. ${ }^{245}$

Bruno Garcia Redondo, por seu turno, sugere que diante da prolação de sentença parcial a parte se utilize do recurso de apelação, aperfeiçoada em autos suplementares, com obediência à relação de documentos estabelecidos para o agravo de instrumento. Isto porque a seu ver “o processamento e o julgamento da apelação não poderão paralisar a instrução restante do processo quanto aos demais pedidos ainda não resolvidos, razão pela qual os autos principais não poderão ser levados à instância superior para apreciação do recurso". Quanto ao seu processamento, esclarece que "ainda que se denomine esse recurso de apelação em autos suplementares, sua interposição deverá continuar sendo realizada perante o próprio juízo monocrático (art. 514 do CPC), para que realize o juízo de admissibilidade (art. 518)". Por fim, conclui ser inadequada a alcunha apelação por instrumento, por ensejar o processamento nos moldes do agravo, em que a interposição do recurso é realizada diretamente perante o segundo grau de jurisdição. $^{246}$

Quer nos parecer que no caso em estudo a solução encontrada é a aplicação do princípio da fungibilidade recursal, já que presentes os requisitos necessários para tanto: presença de dúvida objetiva a respeito do recurso cabível, inexistência de erro grosseiro na interposição do recurso e prazo (para aqueles que entendem pela subsistência deste pressuposto).

No que diz respeito à adequação do procedimento a ser seguido em caso de aplicação do princípio da fungibilidade, em especial no que tange a interposição dos recursos de agravo e de apelação, oportuna lição de Marinoni e Arenhart, para os quais deve haver a intimação da parte recorrente para ajustar a petição aos preceitos do procedimento correspondente ao recurso apropriado. ${ }^{247}$

\footnotetext{
${ }^{245}$ NERY JÚNIOR, Nelson; NERY, Rosa Maria Andrade. Código de Processo Civil comentado e legislação processual civil extravagante em vigor, cit., p. 581. Também entende pelo cabimento do recurso de agravo de instrumento quando houver julgamento liminar de improcedência tão somente com relação a uma parcela da pretensão do autor Daniel Amorim Assumpção Neves. (NEVES, Daniel Amorim Assumpção. Recurso contra a sentença de improcedência liminar (art. 285-A do CPC) e o juízo de retratação, cit., p. 53). ${ }^{246}$ REDONDO, Bruno Garcia. Sentença parcial de mérito e apelação em autos suplementares, cit., p. 153.

${ }^{247}$ MARINONI, Luiz Guilherme; ARENHART, Sérgio Cruz. Curso de processo civil: processo de conhecimento. São Paulo: Ed. Revista dos Tribunais, 2007. 2 v, p. 506.
} 
De todo o exposto, temos que somente em casos excepcionais deverá o juiz proferir uma sentença prévia de improcedência parcial, isto é, que abarque apenas uma parcela da pretensão do autor, uma vez que, nessas hipóteses, apesar da natureza de sentença da decisão, razoável a interpretação de cabimento do recurso de agravo de instrumento, o que afastará a utilização à espécie dos preceitos constantes do art. 285-A, parágrafos $1^{\circ}$ e $2^{\circ}$, do CPC.

Ademais, não parece ser muito coerente proferir julgamento prévio de mérito parcial uma vez que, como já tivemos a oportunidade de salientar no presente estudo, o mesmo deve ser entendido como um instrumento de racionalização processual, o que não ocorrerá na hipótese, já que, de qualquer forma, a demanda prosseguirá normalmente para apreciar os demais pedidos.

\subsection{Objeto do recurso}

No presente tópico nos deteremos aos provimentos judiciais que tendo por conteúdo o art. 269 do CPC, encerram, com fulcro no art. 285-A do CPC, de forma prévia, a etapa cognitiva dos processos, motivo pelo qual concentraremos nossos estudos no recurso de apelação.

Feita essa pequena consideração, temos que todo recurso é composto de dois elementos: volitivo e descritivo.

No que diz respeito ao primeiro elemento, temos que o recurso é prolongamento do direito de ação, motivo pelo qual deve haver, por parte do recorrente, manifestação volitiva no sentido de ter julgado o recurso. Os recursos são atos voluntários de não permitir o trânsito em julgado de uma decisão. Por meio do princípio da voluntariedade, “condicionase a existência de um recurso exclusivamente à vontade da parte, que demonstra a vontade de recorrer com o ato de interposição do recurso". ${ }^{248}$

Como se vê, o princípio da voluntariedade está estritamente ligado ao princípio dispositivo através do qual se fixa ao julgador o âmbito de conhecimento e de decisão da questão posta à apreciação da Justiça. A natureza do ônus de recorrer decorre do fato de a decisão não poder ser modificada, senão por pedido da parte.

${ }^{248}$ Cf. NEVES, Daniel Amorim Assumpção. Manual de direito processual civil. Rio de Janeiro: Forense; São Paulo: Método, 2009. p. 521. 
Pelo princípio da voluntariedade, a parte deve ter vontade em recorrer e aduzirá suas razões de inconformismo, que limitará o âmbito de devolutividade do recurso apresentado. Importante ressaltar que o efeito devolutivo refere-se à possibilidade dos recursos provocarem o reexame de decisão. Consoante o caput do art. 515 do Código de Processo Civil, a extensão do efeito devolutivo do recurso de apelação é aferida pela dimensão da impugnação manifestada pelo recorrente, princípio esse consagrado pela máxima tantum devolutum quantum appellatum.

A mera interposição do recurso já demonstra a vontade de recorrer da parte. Não importa se o recurso será ou não recebido ou conhecido, ou ainda se é total ou parcial. A parte, por outro lado, demonstra sua vontade de não recorrer pela não interposição do recurso, quando demonstre concordância com a decisão proferida (aquisciência), ou ainda, por meio da renúncia ao direito de recorrer.

O segundo elemento, o descritivo, versa sobre a dialeticidade, isto porque todo recurso deve possuir fundamentação e pedido, para permitir o contraditório e para delimitar a atuação do Tribunal. Tal princípio encontra-se em consonância com o princípio dispositivo (ao delimitar o mérito recursal) e com o princípio do contraditório.

A fundamentação ou causa de pedir recursal serve para tornar o recurso um exercício dialético porque é por meio das razões do recurso que se admite as contrarrazões recursais. Dialeticidade é debate, estabelecer divergência que só ocorrerá quando houver fundamentação, ainda que sucinta. ${ }^{249}$

A causa de pedir recursal visa combater os vícios contidos na decisão impugnada, que se traduzem nos errores in procedendo, vícios de natureza formal, e errores in iudicando, vícios de natureza substancial. O pedido, por sua vez, visa limitar a atuação do tribunal. Somente diante deste pode-se pensar em acolhimento e não acolhimento.

\footnotetext{
${ }^{249}$ Nesse sentido: "AÇÃO DE COBRANÇA - EXPURGOS INFLACIONÁRIOS - CADERNETA DE POUPANÇA PRESSUPOSTOS - PRINCÍPIO DA DIALETICIDADE - MOTIVAÇÃO - TRANSCRIÇÃO IPSIS LITERIS DA CONTESTAÇÃO - INSUFICIÊNCIA - NÃO-CONHECIMENTO DOS RESPECTIVOS CAPÍTULOS DO RECURSO. - Particularmente no que tange à motivação dos recursos, vige no sistema recursal pátrio o princípio da dialeticidade, pelo qual o recurso deve conter os fundamentos de fato e de direito que consubstanciam as razões do inconformismo com a decisão objeto de impugnação. - A mera transcrição ipsis literis do teor da contestação ou de outras peças processuais anteriores à sentença não pode, jamais, ser suficiente para que se atenda ao requisito da fundamentação recursal. A bem da verdade, o comportamento da parte que, ao invés de se contrapor a cada ponto da decisão, limita-se a reproduzir alegações anteriores, revela intolerável e inaceitável comodismo, que deve ser repudiado pelo Judiciário”. (TJ-MG - 18 ${ }^{\mathrm{a}}$ CÂMARA CÍVEL - APELAÇÃO CÍVEL $\mathrm{N}^{\circ}$ 1.0672.07.251132-8/001 - COMARCA DE SETE LAGOAS - APELANTE(S): BANCO BRASIL S/A - APELADO(A)(S): DIVINO JOSÉ DE PAULA - RELATOR: EXMO. SR. DES. ELPÍDIO DONIZETTI) - grifos nossos.
} 
No recurso da sentença de improcedência prima facie, o autor, além de procurar demonstrar que seu direito procede, deve demonstrar que o seu caso não é idêntico aos outros, nos quais houve sentença de improcedência, que o posicionamento do magistrado de primeira instância não é o mesmo dos tribunais ou, ainda, que a matéria ventilada não é exclusivamente de direito. ${ }^{250}$

Importante frisar que, no direito processual civil brasileiro, as razões do recurso têm que ser apresentadas no ato de interposição, sob pena de preclusão consumativa. Uma vez interposto o recurso, não é possível alterar as razões recursais, por já haver passado a oportunidade de fazê-lo.

Deste modo, pelo denominado princípio da complementaridade, o recorrente somente poderá complementar a fundamentação de seu recurso já interposto, se houver alteração ou integração da decisão, em virtude de acolhimento de embargos de declaração.

É interessante notar que a complementação somente poderá ocorrer nos limites da nova sucumbência, isto é, não pode o recorrente se aproveitar da ocasião para impugnar parte da decisão que deveria ter impugnado, mas não o fez no momento oportuno. Além disso, tem-se que uma vez exercido o direito de recorrer, consumou-se a oportunidade de fazê-lo, de sorte a impedir que o recorrente torne a impugnar o pronunciamento judicial já impugnado, seja pelo mesmo ou outro tipo de recurso.

Caso sejam protocolados dois recursos, o segundo é considerado um ato juridicamente inexistente, vez que ao protocolar o primeiro ocorre preclusão. Pelo mesmo sentido, entendemos pela impossibilidade de interposição de recurso adesivo pela parte que já recorrera de forma independente. ${ }^{251}$

Percebe-se, pelo exposto, que não poderá o autor, que já interpôs recurso de apelação na forma do $\S 1^{\circ}$ do art. 285-A do CPC, apresentar recurso adesivo à resposta ao recurso apresentada pelo réu.

Por fim, conforme expressa disposição legal, incumbe ao recorrente interpor apelação para o Tribunal correspondente a fim de demonstrar que o julgamento efetivado não foi acertado, expondo as razões para a reforma ou anulação da sentença recorrida. Em tal desiderato, o autor pode sustentar a anulação da sentença, porque inadequada a utilização do disposto no art. 285-A do CPC (error in procedendo), motivo pelo qual se faz

\footnotetext{
${ }^{250}$ Cf. POITTEVIN, Ana Laura González. O art. 285-A do CPC e os embargos de declaração, cit., p. 620.

${ }^{251}$ Em tal sentido, REsp 179.586/RS, Rel. Ministro FRANCISCO PEÇANHA MARTINS, SEGUNDA

TURMA, julgado em 16/11/2000, DJ 18/12/2000, p. 175.
} 
necessário o regular processamento da demanda, com seu retorno ao primeiro grau de jurisdição, seja para requerer a reforma da sentença, em virtude da existência de error in iudicando.

\subsection{Juízo de admissibilidade do recurso de apelação}

No sistema processual pátrio, interposto o recurso de apelação, duas espécies de exame serão feitas pelo órgão jurisdicional competente para sua apreciação: o juízo de admissibilidade e o juízo de mérito. O juízo de admissibilidade ${ }^{252}$ é duplo, ou seja, é feito em duas oportunidades.

Primeiramente, o órgão no qual ocorreu a interposição manifesta-se positiva ou negativamente quanto à admissibilidade do recurso. Entendendo pelo recebimento do recurso, o juízo ou o tribunal a quo procede ao seu encaminhamento para o tribunal ad quem, permitindo a apreciação, em segunda etapa, das condições para a admissibilidade do recurso pelo órgão julgador.

Deste modo, antes de apreciar o mérito recursal, deve ser analisado uma série de requisitos (também denominados pressupostos ou condições), que levarão ao conhecimento ou não do recurso interposto.

Não há unanimidade na doutrina no que se refere ao rol dos chamados requisitos de admissibilidade recursal ${ }^{253}$. Contudo, optamos no presente trabalho, pela classificação em requisitos intrínsecos e extrínsecos.

\footnotetext{
${ }^{252}$ Interessante trazer à baila lição de Ovídio Baptista para o qual: "nos recursos haverá sempre a necessidade de uma investigação prévia, destinada a averiguar se o recurso é possível, numa dada hipótese, e se aquele que o interpôs cumpriu todos os requisitos exigidos por lei para que tal inconformidade merecesse o reexame pelo órgão encarregado de julgá-lo. Este exame preliminar sobre o cabimento do recurso denomina-se juízo de admissibilidade, transposto o qual, em sentido favorável ao recorrente, passará o órgão recursal ao juízo de mérito do recurso”. (SILVA, Ovídio A. Baptista da. Curso de processo civil: processo de conhecimento. 7. ed. Rio de Janeiro: Forense, 2005. v. 1, p. 395).

${ }^{253}$ Flávio Cheim Jorge destaca a existência na doutrina pátria de dois critérios utilizados para classificar os denominados requisitos ou pressupostos recursais. O primeiro, encampado por Seabra Fagundes, distingue os requisitos em subjetivos (relacionados à pessoa do recorrente) e objetivos (relacionados ao próprio recurso). O segundo, empregado por Barbosa Moreira, classifica os requisitos em intrínsecos e extrínsecos. Após analisar ambos, conclui o autor que "tanto uma como outra classificação atendem igualmente ao objetivo por elas delineados, que é, justamente, esquematizar um quadro completo e coerente de todos os requisitos de admissibilidade dos recursos. Não existe, propriamente, distinção de conteúdo entre ambas as classificações. Não é possível dizer que uma supera a outra em termos de qualidade”. (JORGE, Flávio Cheim. Teoria geral dos recursos cíveis, cit., p. 106-107).
} 
Os pressupostos intrínsecos são aqueles que se referem à própria existência do poder de recorrer e dividem-se em legitimidade, interesse recursal e possibilidade jurídica do recurso ou cabimento.

A legitimidade refere-se à autorização legal dada em abstrato para alguém recorrer, nos termos do disposto no art. 499 do CPC. Em regra, são legitimadas as partes, o terceiro prejudicado e o Ministério Público (seja como autor ou fiscal da lei). Percebe-se, assim, que a lei procura restringir o rol dos legitimados a recorrer àqueles que sofrerão os principais efeitos de uma determinada decisão.

No caso de recurso de apelação em face de sentença proferida com fundamento no art. 285-A, do CPC, temos que, em regra, o recorrente será o autor, uma vez que até então, muito provavelmente, o réu ainda nem terá conhecimento acerca da existência do processo.

No que diz respeito ao interesse recursal, costuma-se relacioná-lo com a existência da sucumbência, isto é, do potencial ou concreto gravame trazido pela decisão à parte. Inexistindo qualquer gravame à parte recorrente, revela-se a carência da parte de interesse recursal. Registre-se, por oportuno, que há entendimento no sentido de que tanto no caso do terceiro prejudicado como do Ministério Público quando atua como fiscal da lei não é adequado condicionar a existência do interesse de recorrer à existência de sucumbência do recorrente. ${ }^{254}$

Versa o interesse em recorrer na utilidade do recurso interposto, sendo que só haverá interesse em recorrer quando a parte objetivar com o recurso interposto obter uma posição jurídica mais benéfica do que aquela que lhe tenha sido oferecida pela decisão impugnada. Para que reste configurado o interesse em recorrer, além da necessidade do recurso, deverá ser o mesmo adequado. A adequação, conforme já salientamos, pressupõe o uso do recurso cabível e útil para reverter a situação jurídica no caso concreto.

A sucumbência pode ainda ser vista sob dois aspectos: material e formal. A sucumbência material ocorre quando o processo não dá tudo o que a parte poderia obter no mundo fático. ${ }^{255}$ A sucumbência formal, por sua vez, ocorre quando o processo não corresponde a tudo o que a parte poderia obter: uma sentença totalmente procedente e

\footnotetext{
${ }^{254}$ Cf. NEVES, Daniel Amorim Assumpção. Interesse recursal e sucumbência. Disponível em: $<$ http://www.professordanielneves.com.br/artigos/201011151803310.interesseemrecorrer.pdf $>$. Acesso em: 08 nov. 2012.

${ }^{255}$ Diz respeito, assim, ao "bem ou bens da vida que a parte poderia obter em virtude do processo judicial e que não obteve em razão da decisão judicial". (Cf. NEVES, Daniel Amorim Assumpção. Interesse recursal e sucumbência, cit.).
} 
formalmente perfeita para o autor ou, ainda, improcedência total do pedido da parte autora, para o réu.

Verifica-se, a título ilustrativo, a ausência de pressuposto de admissibilidade intrínseco do recurso de apelação consubstanciado no interesse em recorrer quando, num determinado caso, os argumentos da insurgência da parte autora, em sede de apelação, não encontram respaldo, por ter sido proferida sentença com observância do previsto no art. 285-A do Código de Processo Civil, constando desta menção ao julgado anteriormente proferido, bem como dados suficientes para sua identificação. ${ }^{256}$

O terceiro requisito intrínseco é a possibilidade jurídica do recurso, que deve ser entendida como o cabimento do recurso. Há necessidade, assim, de previsão legal dispondo sobre a possibilidade de utilização da via recursal para atacar determinada decisão, bem como que o recurso escolhido seja o adequado para ensejar o reexame da questão.

Em posição contrária àqueles que entendem existir um quarto pressuposto intrínseco de admissibilidade, a inexistência de algum fato impeditivo ou extintivo do direito de recorrer ${ }^{257}$, Nelson Luiz Pinto prefere excluir do elenco dos pressupostos intrínsecos tal requisito, por entender tratar-se de categoria atinente à do interesse em recorrer. ${ }^{258}$

Indo adiante, os requisitos extrínsecos dizem respeito ao modo de exercer o poder recursal e costumam ser divididos, de acordo com a melhor doutrina, em tempestividade, preparo e regularidade procedimental ${ }^{259}$.

A tempestividade constitui requisito de admissibilidade de qualquer recurso e refere-se à necessidade de que o recurso seja interposto no prazo estabelecido em lei. Se o recurso não for interposto em tempo hábil, ele é inadmissível, porque intempestivo, sendo que a situação não mais poderá ser alterada.

Convém ressaltar o entendimento firmado tanto no Superior Tribunal de Justiça ${ }^{260}$ quanto no Supremo Tribunal Federal ${ }^{261}$, no sentido de ser intempestivo o recurso

\footnotetext{
${ }^{256}$ Cf. AC 00099498920094036183, DESEMBARGADORA FEDERAL VERA JUCOVSKY, TRF3 OITAVA TURMA, e-DJF3 Judicial 1 DATA:24/08/2012.

${ }^{257}$ Por todos, confira-se: JORGE, Flávio Cheim. Teoria geral dos recursos cíveis, cit., p. 149.

${ }^{258}$ PINTO, Nelson Luiz. Manual dos recursos cíveis. São Paulo: Malheiros Ed., 2002. p. 63.

${ }^{259}$ Adotam esse entendimento, entre outros: JORGE, Flávio Cheim. Teoria geral dos recursos cíveis, cit., p. 107 e PINTO, Nelson Luiz. Manual dos recursos cíveis, cit., p. 62.

${ }^{260}$ No STJ, a título exemplificativo, confira-se o AgRg no AREsp 153.194/PE, Rel. Ministro NAPOLEÃO NUNES MAIA FILHO, PRIMEIRA TURMA, julgado em 02/10/2012, DJe 05/10/2012.

${ }^{261}$ Nesse sentido, destaca-se: "AGRAVO DE INSTRUMENTO - "AGRAVO REGIMENTAL" INTEMPESTIVO - TERMO INICIAL DOS PRAZOS RECURSAIS - PETIÇÃO RECURSAL PROTOCOLIZADA NO SUPREMO TRIBUNAL FEDERAL APÓS O EXAURIMENTO DO PRAZO LEGAL
} 
interposto antes do prazo, isto é, antes da publicação no diário oficial da sentença/ acórdão. Com efeito, tais órgãos consideram intempestivos por prematuridade os recursos especial e/ou extraordinário interpostos antes da publicação do acórdão dos embargos de declaração, exigindo que, após a publicação deste, seja o recurso reiterado, sob pena de não ser conhecido.

A respeito do tema, é de se destacar inclusive a existência de súmula do STJ ${ }^{262}$. Com efeito, a necessidade de posterior ratificação do recurso só é afastada excepcionalmente como, por exemplo, "quando os embargos de declaração fora oposto por corréu e as teses ali ventiladas não guardam qualquer relação de prejudicialidade com as teses expostas no recurso especial", 263

Heitor Vitor Mendonça Sica manifesta-se de forma desfavorável a esse entendimento por entender que a questão em debate não diz respeito à tempestividade (requisito extrínseco de admissibilidade do recurso) e sim ao cabimento (requisito intrínseco) dos recursos especial e extraordinário. Ademais, salienta a impossibilidade dos Tribunais estipularem condição não prevista em lei - ratificação do recurso - por configurar caso de afronta ao princípio do devido processo legal. Por fim, conclui o autor: "Com o mais elevado e devido respeito àqueles que a acolhem, está-se, aqui, diante de mais uma "armadilha" criada pelos Tribunais Superiores para não conhecer de recursos, consistente na criação de uma formalidade que não encontra previsão legal”. ${ }^{264}$

Pensamos igualmente que a interposição do recurso antes da intimação não pode levar ao seu não conhecimento em virtude de intempestividade. Com efeito, se de algum

- DECISÃO QUE NÃO CONHECEU DO “AGRAVO REGIMENTAL”, POR EXTEMPORANEIDADE RECURSO IMPROVIDO. - A intempestividade dos recursos tanto pode derivar de impugnações prematuras (que se antecipam à publicação dos acórdãos) quanto decorrer de oposições tardias (que se registram após o decurso dos prazos recursais). Em qualquer das duas situações - impugnação prematura ou oposição tardia -, a consequencia de ordem processual é uma só: o não conhecimento do recurso, por efeito de sua extemporânea interposição". (AI 700540 AgR-AgR, Relator(a): Min. CELSO DE MELLO, Segunda Turma, julgado em 06/09/2011, DJe-185 DIVULG 26-09-2011 PUBLIC 27-09-2011 EMENT VOL-02595-03 PP-00365). Confira-se, também: AI 793953 AgR-ED, Relator(a): Min. JOAQUIM BARBOSA, Segunda Turma, julgado em 28/08/2012, ACÓRDÃO ELETRÔNICO DJe-196 DIVULG 0410-2012 PUBLIC 05-10-2012.

262 “É inadmissível o recurso especial interposto antes da publicação do acórdão dos embargos de declaração, sem posterior ratificação”. (Súmula 418, CORTE ESPECIAL, julgado em 03/03/2010, DJe $11 / 03 / 2010)$

${ }^{263}$ Cf. AgRg no REsp 1032657/PR, Rel. Ministro JORGE MUSSI, QUINTA TURMA, julgado em 02/08/2012, DJe 15/08/2012.

${ }^{264}$ SICA, Heitor Vitor Mendonça. Recurso intempestivo por prematuridade? In: NERY JÚNIOR, Nelson; WAMBIER, Teresa Arruda Alvim (Coord.). Aspectos polêmicos e atuais dos recursos cíveis e assuntos afins. São Paulo: Ed. Revista dos Tribunais, 2007. v. 11, p. 134-144. 
modo a parte teve acesso ao conteúdo da decisão, antes mesmo de sua publicação, nada mais coerente que a partir dali tenha fluência o prazo recursal.

Além de ser tempestivo, o recorrente deve comprovar, no ato da interposição do recurso, a realização do preparo previsto no art. 511 do CPC, sob pena de deserção, o qual somente é dispensado se a parte gozar do benefício de justiça gratuita.

Convém salientar que o art. 519 do CPC estabelece a necessidade de comprovação de preparo para interposição do recurso de apelação. Desta feita, deve o recorrente comprovar ter feito o recolhimento prévio das despesas referentes ao processamento do recurso.

Finalmente, a regularidade formal é o requisito pelo qual se exige que o recurso seja interposto obedecendo estritamente à forma estabelecida em lei. Dito de outro modo, não é admissível recurso que não observe as formalidades legais impostas ao ato de recorrer. Em que pese exista previsão legal referente aos requisitos formais para interposição de cada um dos recursos, existem alguns requisitos genéricos, atinentes a todos os recursos, tais como a necessidade petição escrita (excepcionalmente se admite a interposição oral como no caso do agravo retido nas audiências de instrução e dos embargos de declaração nos juizados especiais), identificação das partes, motivação, razão do inconformismo, pedido de nova decisão, e etc.

Em suma, a admissibilidade do recurso interposto em face de sentença proferida tendo por medida o art. 285-A do CPC ensejará a análise de todos os pressupostos exigidos para o recurso de apelação de uma forma geral.

O magistrado de primeira instância ao realizar o exame provisório ${ }^{265}$ de admissibilidade da apelação deverá verificar se estão presentes todos os requisitos

\footnotetext{
${ }^{265}$ Nesse sentido: "PROCESSO CIVIL. TRIBUTÁRIO. ISS. ARRENDAMENTO MERCANTIL. DISCUSSÃO SOBRE A APLICABILIDADE DA SÚMULA 138/STJ. JUÍZO DE $1^{\circ}$ GRAU. APLICAÇÃO DO $\$ 1^{\circ}$ DO ART. 518 DO CPC. DECISÃO DO TRIBUNAL QUE DETERMINA O PROCESSAMENTO DO RECURSO DE APELAÇÃO. JUÍZO POSITIVO DE ADMISSIBILIDADE. PROVISORIEDADE. AUSÊNCIA DE INTERESSE RECURSAL. (...) 2. A decisão que admite o processamento da apelação é irrecorrível, pois, em tais casos, o recurso é desnecessário, já que o juízo positivo de admissibilidade é provisório e será novamente realizado pelo órgão ad quem. Eventual irresignação contra tal decisão apenas poderá ser arguida nas contrarrazões, como matéria preliminar de não conhecimento do recurso, possibilitando-se, futuramente e, caso necessário, que a matéria seja novamente agitada por meio do recurso cabível contra o julgamento final do apelo. 3. A decisão do tribunal que confere provimento ao agravo configura juízo de admissibilidade positivo e provisório do recurso de apelação. O pronunciamento do órgão ad quem acerca do mérito do agravo apenas autoriza o processamento da apelação, não constituindo óbice ao novo exame dos requisitos de admissibilidade recursais pelo tribunal a quo, no momento em que for julgar o apelo. 4 . A revogabilidade do juízo de admissibilidade recursal ocorre porque a apreciação das condições de procedibilidade do recurso não se submetem à preclusão, sendo consideradas como de ordem pública,
} 
necessários para que o recurso possa ser remetido para o Tribunal. Caso seja negado seguimento ao recurso, outra solução não terá o apelante a não ser interpor o recurso de agravo, sob a modalidade de instrumento.

\subsubsection{Súmula de Jurisprudência dominante impeditiva de recurso: um novo requisito de admissibilidade recursal?}

$\mathrm{O}$ art. 518 do CPC foi modificado pela Lei n. 11.276/2006 que alterou a sistemática do dispositivo ao inserir o $\S 1^{\circ}$ que tem por finalidade o fortalecimento dos precedentes. Com efeito, a capacidade para inadmitir o recurso, que já havia sido confiada ao relator pelo art. 557 do CPC, passa a poder ser exercido pelo próprio juízo de primeira instância. Confira-se a redação do dispositivo:

Art. 518. (...).

$\S 1^{\circ}$ O juiz não receberá o recurso de apelação quando a sentença estiver em conformidade com súmula do Superior Tribunal de Justiça ou do Supremo Tribunal Federal.

$\S 2^{\circ}$ Apresentada a resposta, é facultado ao juiz, em cinco dias, o reexame dos pressupostos de admissibilidade do recurso.

Pela leitura do artigo, temos que o não recebimento do recurso poderá ocorrer liminarmente, nos moldes do previsto no $\S 1^{\circ}$ do art. 518 ou depois de oferecida a resposta pelo recorrido, tal como proposto pelo parágrafo $2^{\circ}$ do mencionado dispositivo.

O objetivo é reduzir recursos sem margem de êxito. Em tese aplica-se a todos os recursos interpostos no juízo a quo, uma vez que aqueles interpostos diretamente no tribunal sujeitam-se ao art. 557 do CPC.

Convém salientar que o texto emprega a expressão "súmula" em sentido amplo. Não se trata, assim, de Súmula vinculante, e sim de uma Súmula comum do STJ ou do STF. A decisão não precisa reproduzir nem mencionar a súmula, basta que esteja em

passíveis de conhecimento, portanto, de ofício pelo órgão julgador. 5. O decisum do tribunal opera efeito substitutivo sobre a decisão de $1^{o}$ Grau que não admite o recurso de apelação. Logo, se não é cabível recurso contra a decisão singular que imprime juízo positivo de admissibilidade à apelação, o mesmo raciocínio deve ser aplicado ao acórdão da Corte Estadual que determina a subida do recurso por meio do provimento do agravo de instrumento. 6. Recurso especial não conhecido". (RESP 200802432686, CASTRO MEIRA, STJ - SEGUNDA TURMA, DJE DATA:23/06/2009.) 
conformidade com ela, isto é, adotar o mesmo fundamento e conclusão contidos na súmula.

Para que a súmula tenha força impeditiva é necessário que ela esteja em vigor, isto é, não pode estar cancelada e deve, ainda, representar o entendimento atual (não pode haver decisões posteriores a ela em sentido diverso) do tribunal que a editou.

De acordo com Nelson Nery Jr. e Rosa Nery a norma do $\S 1^{\circ}$ do art. 518 seria inconstitucional uma vez que, na prática, transforma em vinculantes todos os verbetes simples das súmulas do STF e do STJ, em afronta ao sistema instituído pelo art. 103-A da $\mathrm{CF}$, que arquitetou tal efeito apenas para os verbetes editados com esse específico propósito, exclusivamente pelo Plenário do STF, mediante decisão de dois terços dos seus membros. ${ }^{266}$

Em que pese o brilhantismo dos autores, não concordamos com tal argumento, uma vez que para que ocorra o efeito impeditivo do recurso em primeiro grau, apenas se exige a observância aos precedentes jurisdicionais sumulados pelo Supremo Tribunal Federal ou pelo o Superior Tribunal de Justiça, o que está em consonância com os princípios da segurança jurídica e da duração razoável do processo, evitando futuras discussões no que diz respeito à interpretação da lei. ${ }^{267}$

Impõe registrar que o artigo $518, \S 1^{\circ}$, do $\mathrm{CPC}$, condiciona a sua aplicação à existência de súmulas dos Colendos STJ e STF, mas não à jurisprudência predominante, silenciando o legislador nesse ponto, ao que parece, com o intuito de limitar a extensão do paradigma de comparação.

Questão oportuna consiste em saber se o art. 518, $\S 1^{\circ}$ do CPC, acrescentado pela Lei $\mathrm{n}^{\circ} 11.276 / 2006$, ao atribuir ao juízo a quo a possibilidade de não receber o recurso de apelação quando a sentença estiver em conformidade com súmula do Superior Tribunal de Justiça ou do Supremo Tribunal Federal, constitui um novo requisito de

\footnotetext{
${ }^{266}$ NERY JÚNIOR, Nelson; NERY, Rosa Maria Andrade. Código de Processo Civil comentado e legislação processual civil extravagante em vigor, cit., p. 900.

${ }^{267}$ No mesmo sentido são as considerações de José Henrique Mouta Araújo quando, em comentários ao $§ 1^{\circ}$, do artigo 518, assevera que "pretende a nova alteração legislativa evitar a tramitação de apelação que pretenda impugnar decisão fundada em súmula, caminhando em consonância com os ideais da Emenda Constitucional 45 (que implantou efeito vinculante às súmulas do STF em matéria constitucional, ex vi do art. 103-A da CF/88) e com a alteração processual implementada pela Lei 11.277/06 (que permite ao magistrado de $1^{\circ}$ grau a resolução de mérito initio litis, sem sequer determinar a citação do réu para responder ao pedido)”. (ARAÚJO, José Henrique Mouta. Súmula impeditiva de recursos: uma visão sobre o atual quadro processual brasileiro. Revista Dialética de Direito Processual, São Paulo, n. 39, p. 86, jun. 2006).
} 
admissibilidade do recurso ou, ainda, autorização legal para que o juízo de primeira instância ingresse no mérito recursal.

Com o devido respeito àqueles que entendem tratar-se de mais um pressuposto de admissibilidade para os recursos ${ }^{268}$, a ser analisado conjuntamente com aqueles tratados no item anterior, temos para nós que no caso em tela está a se efetivar verdadeira apreciação do mérito recursal. ${ }^{269}$

A propósito, Luiz Rodrigues Wambier, Teresa Arruda Alvim Wambier e José Garcia Medina defendem que o recurso não é indeferido em virtude da ausência de um dos seus requisitos de admissibilidade, uma vez que analisar se o julgado está ou não em conformidade com o entendimento dos Tribunais Superiores é questão pertinente ao mérito do recurso. ${ }^{270}$

Com efeito, o $\S 1^{\circ}$ do art. 518 do CPC não traz novo pressuposto recursal de admissibilidade da apelação, mas permite por meio da denominada "súmula impeditiva de recurso", que o juiz possa examinar a identidade entre o enunciado da súmula e o julgado proferido e, se for o caso, negar prosseguimento ao recurso, quando constatar que a sentença recorrida está lastreada em súmula do entendimento do STJ ou STF. Nesse caso, não há que se falar em ofensa ao duplo grau obrigatório de jurisdição, pois se trata de

\footnotetext{
${ }^{268}$ Flávio Cheim Jorge, a título de exemplo, entende que o dispositivo deve "ser enquadrado dentro do requisito do interesse recursal”. (JORGE, Flávio Cheim. Teoria geral dos recursos cíveis, cit., p. 147).

${ }^{269}$ Nelson Rodrigues Netto manifesta o mesmo entendimento ao assinalar que "apesar de o preceito legal dispor que o 'juiz não receberá o recurso de apelação', a norma não trata de requisito de admissibilidade do recurso de apelação. A imprecisão da linguagem utilizada pelo legislador não tem o condão de alterar a natureza dos institutos”. (RODRIGUES NETTO, Nelson. Cognição limitada do mérito da apelação pelo juízo de primeiro grau (art. 518, § $1^{\circ}$, do CPC). In: NERY JÚNIOR, Nelson; WAMBIER, Teresa Arruda Alvim (Coord.). Aspectos polêmicos e atuais dos recursos cíveis e assuntos afins. São Paulo: Ed. Revista dos Tribunais, 2007, v. 11, p. 239). Também nessa conclusão: PARENTE, Eduardo de Albuquerque. A súmula impeditiva de recursos e o sistema de precedentes. In: CARMONA, Carlos Alberto (Coord.). Reflexões sobre a reforma do Código de Processo Civil: estudos em homenagem a Ada Pellegrini Grinover, Cândido R. Dinamarco e Kazuo Watanabe. São Paulo: Atlas, 2007. p. 180.

${ }^{270}$ WAMBIER, Luiz Rodrigues; WAMBIER, Teresa Arruda Alvim; MEDINA, José Miguel Garcia. Breves comentários à nova sistemática processual civil 2, cit., p. 226. Nesse mesmo sentido, destacamos: "PROCESSUAL CIVIL. APELAÇÃO. NEGATIVA DE SEGUIMENTO PELO JUIZ A QUO. SENTENÇA RECORRIDA NÃO BASEADA EM SÚMULA. EXAME DE MÉRITO. DESCABIMENTO. 1. O exame de admissibilidade da apelação exercido em primeira instância deve-se ater à verificação dos requisitos legais para a interposição do recurso, sendo permitido ao juiz a quo imiscuir-se no próprio mérito recursal, somente quando a sentença recorrida estiver em consonância com súmula do STJ ou STF (CPC, art. 518, \$1 ${ }^{\circ}$, introduzido pela Lei 11.276/2006). 2. Agravo de instrumento da CEF a que se dá provimento, para determinar o regular processamento de sua apelação”. (AG 200501000718735, JUIZ FEDERAL VALLISNEY DE SOUZA OLIVEIRA, TRF1 - QUINTA TURMA, DJ DATA: 01/06/2006 PAGINA:98.). No Tribunal Regional Federal da $3^{\mathrm{a}}$ Região tem-se o mesmo entendimento, como se vê do AI 00870665220074030000, DESEMBARGADOR FEDERAL LUIZ STEFANINI, TRF3 - PRIMEIRA TURMA, DJF3 DATA: 19/05/2008.
} 
hipótese legal cujo objetivo é impedir a repetição de questões já pacificadas nos Tribunais Superiores.

Indo adiante, convém verificar a possibilidade de uma leitura sistemática do art. 285-A com o conteúdo do art. 518, $\S 1^{\circ}$, do CPC. Ora, parece-nos perfeitamente possível conciliar essas duas técnicas. Com efeito, entendemos que se o juiz julgar improcedente o pedido, aplicando o art. 285-A do CPC, alicerçando sua sentença em súmula do Supremo Tribunal Federal ou do Superior Tribunal de Justiça, não haverá óbice algum para sua combinação com a norma contida no $\S 1^{\circ}$ do art. 518 que disserta que o magistrado não receberá o recurso de apelação quando a sentença prolatada estiver em conformidade com entendimento sumulado dos Tribunais Superiores. ${ }^{271}$

Para a incidência de referido dispositivo a parte deve ter recorrido de sentença que se apoiou em súmulas dos Tribunais Superiores. Todavia, quando a parte não impugna em suas razões de apelação o conteúdo da Súmula adotada na sentença, mas sim a sua inadequada aplicação para o caso concreto, o recurso deve ser admitido, pois só assim haverá o controle pelo juízo ad quem, no que toca à correta adoção do entendimento sumulado para o caso concreto.

Apesar do interessante debate doutrinário e jurisprudencial acerca da natureza jurídica da norma contida no $\S 1^{\circ}$ do art. 518 do CPC, fato é que, na prática, se o magistrado não receber o recurso de apelação restará ao autor/ apelante, interpor recurso de agravo de instrumento, nos termos do art. 522 do CPC, o qual deverá limitar-se à alegação de inaplicabilidade da súmula ou na necessidade de sua revisão.

Sendo interposto esse agravo pelo autor, será o réu citado para respondê-lo no prazo de dez dias, oportunidade em que poderá rechaçar a totalidade dos argumentos apresentados pelo autor no agravo. Ressalte-se, por oportuno, que caso seja dado provimento ao agravo do autor, não haverá prejuízo qualquer ao réu que será, a seguir, citado para responder à apelação, aí no prazo de quinze dias.

À evidência, a súmula impeditiva de recurso prevista no $\S^{\circ}$ do artigo 518 do CPC harmoniza-se com o julgamento imediato de processos repetitivos previsto no artigo 285 -

\footnotetext{
${ }^{271}$ Para Luiz Guilherme Marinoni a conexão entre os preceitos contidos nos artigos $285-\mathrm{A}$ e 518 , $\S 1^{\circ}$, é manifesta: "Ambas aludem a demandas repetitivas. A primeira se preocupa em racionalizar a administração da justiça diante dos processos que repetem teses consolidadas pelo juiz de $1^{\circ}$ grau ou pelos tribunais. A segunda objetiva impedir o prosseguimento do processo nas hipóteses em que há súmula do Superior Tribunal de Justiça ou do Supremo Tribunal Federal". (Ações repetitivas e julgamento liminar, cit., p. 57).
} 
A, uma vez que ambos os institutos visam diminuir o número de demandas repetitivas que povoam o Judiciário.

\subsubsection{Compatibilidade com o artigo 557, caput, do CPC}

Cumpre neste item investigarmos a possibilidade de aplicação em conjunto dos seguintes dispositivos: art. 285-A, 518, $\S 1^{\circ}$ e 557, do CPC. Isto porque o art. 557, caput, do CPC, com a modificação ocorrida em 1998, aumentou os poderes do relator para permitir que, monocraticamente, negue seguimento a recurso "manifestamente inadmissível, improcedente, prejudicado ou em confronto com súmula ou jurisprudência dominante do respectivo tribunal, do Supremo Tribunal Federal, ou de tribunal superior".

No tocante ao conteúdo da expressão “negativa de seguimento”, tem-se que a mesma abarca matérias processuais e o próprio mérito "já que tal negativa pode fundamentar-se na inadmissibilidade e na prejudicialidade, que são questões processuais, bem como em julgamento de improcedência que responde ao próprio pedido recursal, negando-lhe procedência”. ${ }^{272}$

Corroborando este posicionamento, Pedro Miranda de Oliveira observa que tal locução "simplesmente engloba (mistura) as fases de admissibilidade e de mérito ("manifestamente inadmissível, improcedente"), o que é de uma impropriedade científica incoerente com a sistematização do Código, tão merecidamente elogiado quanto à sua cientificidade”. 273

Interpretando conjuntamente tais dispositivos temos as seguintes situações possíveis. Num primeiro cenário, havendo julgamento liminar de improcedência do processo, esposando entendimento em consonância com a orientação sumulada dos Tribunais Superiores, ao magistrado de primeiro grau é dada a possibilidade de negar seguimento à apelação, nos termos do art. 518, §1 ${ }^{\circ}$, do CPC. Contra essa decisão interlocutória, é cabível o recurso de agravo de instrumento, sendo que o art. 527, I, do CPC estabelece permissivo ao relator para negar seguimento ao recurso, liminarmente, nos casos especificados no art. 557.

\footnotetext{
${ }^{272}$ SANTOS, Ernane Fidélis dos. Manual de direito processual civil: processo de conhecimento. 14. ed. São Paulo: Saraiva, 2010. v. 1, p. 807.

${ }^{273}$ OLIVEIRA, Pedro Miranda de. Aspectos polêmicos e atuais dos recursos cíveis e assuntos afins. São Paulo: Ed. Revista dos Tribunais, 2006. p. 433. (Série Aspectos polêmicos e atuais dos recursos, v.9).
} 
De outra banda, se a sentença prolatada liminarmente estiver em conformidade com súmula do Superior Tribunal de Justiça ou do Supremo Tribunal Federal, o recurso de apelação interposto não será recebido. E se o for, será rejeitado de forma monocrática pelo relator de segundo grau (art. 557, do CPC). ${ }^{274}$

A decisão monocrática do relator, desde a redação original do art. 557, sempre comportou recurso, podendo aquele que não se convenceu da justiça da decisão, submetêla ao julgamento do órgão colegiado, que seria competente para o julgamento do recurso, o qual pode reformá-la ou confirmá-la. O meio adequado para veicular a pretensão de ver a decisão monocrática revista é o agravo previsto no art. 557, $\S 1^{\circ}$ (denominado por alguns, de forma equivocada, de "agravo regimental" ${ }^{275}$, como resquício do mecanismo previsto nos Regimentos dos Tribunais) encaminhado ao colegiado com competência para apreciar o referido recurso. Caso o mesmo não seja interposto, ocorrerá preclusão, e a decisão singularmente proferida pelo relator produzirá todos os efeitos atribuídos por lei ao julgamento colegiado, cujo lugar ocupou.

Deve-se tomar cuidado para que não ocorra o emprego inadequado da conjugação de tais institutos, o que ocasionaria o indevido fechamento do sistema e diversos gravames à parte recorrente. Afora tal observação, temos que tais institutos, em conjunto, colaboram para a redução da quantidade dos recursos com feições procrastinatórias. Ademais, permitem uniformizar e racionalizar os julgamentos, atendendo aos princípios da isonomia e da celeridade. Com efeito, se os tribunais superiores já sumularam entendimento sobre argumentos anteriormente apreciados e rejeitados, o recurso que os reiterar deve ser evitado, pois representa mais tempo e despesas para a administração da Justiça em relação a um fim já esperado, o que prejudicaria a razoável duração do processo.

\footnotetext{
${ }^{274}$ Correto, deste modo, o entendimento de Paulo Afonso de Souza Sant'Anna segundo o qual "também é possível ao relator, no tribunal de segunda instância, monocraticamente, negar seguimento ou dar provimento ao recurso de apelação quando estiver diante das hipóteses previstas no art. 557 (caput e parágrafo $1^{\circ}$-A, respectivamente). Na hipótese em que seja dado provimento ao recurso, ante o "manifesto confronto" da sentença com súmula ou jurisprudência dominante do STF ou do STJ, nada impede que o relator, desde logo, também monocraticamente, julgue procedente o pedido inicial”. (SANT'ANNA, Paulo Afonso de Souza. Ações repetitivas e julgamento liminar (art. 285-A do CPC), cit., p. 112).

${ }^{275}$ José Antonio Almeida refuta a utilização da terminologia agravo regimental, optando pela utilização da expressão agravo interno, com a qual concordamos. (ALMEIDA, José Antonio. O agravo interno e a ampliação dos poderes do relator. In: NERY JÚNIOR, Nelson; WAMBIER, Teresa Arruda Alvim (Coord.). Aspectos polêmicos e atuais dos recursos cíveis e de outros meios de impugnação às decisões judiciais. São Paulo: Ed. Revista dos Tribunais, 2003. v. 7, p. 331). Também Athos Gusmão Carneiro entende que o melhor termo a ser empregado à espécie é "agravo interno", distinguindo-o do agravo retido e do agravo por instrumento. (CARNEIRO, Athos Gusmão. Poderes do relator e Agravo Interno - Arts. 557, 544 e 545 do CPC. Revista de Processo, São Paulo, v. 25 n. 100, p. 20, out./ dez. 2000).
} 


\subsection{Juízo de retratação (Art. 285-A, $§ 1^{\circ}$, do CPC)}

Regra geral, os recursos são oferecidos perante o próprio juízo que proferiu a decisão recorrida, ao qual caberá tão só processá-lo, isto é, analisar os requisitos de admissibilidade.

Todavia, em alguns casos expressamente previstos em lei admite-se que o próprio juízo recorrido (o juízo a quo), além de proceder ao juízo de admissibilidade, também analise o mérito do recurso. Nessas hipóteses, caso convencido o magistrado do acerto do recurso (e da falha da decisão), deverá reapreciar a decisão recorrida. Exercerá o chamado juízo de retratação.

É o que ocorre hoje em dia na apelação contra o indeferimento da inicial (art. 296 do CPC), nas apelações interpostas nos processos afetos à competência da Justiça da Infância e Juventude (art. 198, inc. VIII, Lei 8.069/90) e agora com o art. 285-A, $\S 1^{\circ}$. Representa tal possibilidade exceção ao disposto no art. 463 do CPC que determina que publicada a sentença, o magistrado só poderá modificá-la na ocorrência das hipóteses dos incisos I e II, quais sejam: com o fito de corrigir, de ofício ou a requerimento da parte, erros materiais ou de cálculos ou por intermédio de embargos declaratórios.

Uma vez pronunciada sentença de improcedência com fundamento no art. 285-A, surge para o autor ou qualquer das pessoas elencadas no art. 499 do CPC, a possibilidade de interpor recurso de apelação por petição dirigida ao magistrado prolator da decisão impugnada que poderá, em cinco dias, depois de realizar o juízo de admissibilidade ${ }^{276}$ e também verificar se a sentença está em consonância com súmula de um dos tribunais superiores, dizer se mantém ou não a sua sentença.

Tal prazo é considerado impróprio por se entender que seu decurso em branco não ensejará preclusão temporal, já que poderá o magistrado anular a sentença enquanto não seja determinada a citação do demandado para responder ao apelo. ${ }^{277}$

\footnotetext{
${ }^{276}$ Daniel Amorim Assumpção Neves destaca que o juízo de retratação somente ocorrerá após a realização do juízo de admissibilidade pelo magistrado de primeiro grau, justificando que "essa circunstância é consequência natural da ausência de geração de efeitos de recurso que não passa pelo juízo de admissibilidade, não se podendo imaginar que a retratação se dê em um recurso não recebido ou não conhecido". (NEVES, Daniel Amorim Assumpção. Recurso contra a sentença de improcedência liminar (art. 285-A do CPC) e o juízo de retratação. Revista Dialética de Direito Processual, São Paulo, n. 54, p. 55 , set. 2007).

${ }^{277}$ SÁ, Djanira Maria Radamés de; PIMENTA, Haroldo. Reflexões iniciais sobre o art. 285-A do Código de Processo Civil. Revista de Processo, São Paulo, v. 31 n. 133, p. 147-148, mar. 2006.
} 
O juízo de retratação previsto no art. 285-A, $\S 1^{\circ}$ do CPC pouco difere daquele estabelecido contra o indeferimento da inicial (art. 296, do CPC), motivo pelo qual faremos apenas algumas observações sobre o tema.

Contra a sentença que indefere a inicial por inobservância do disposto no art. 295, do CPC, cabe apelação com juízo de retratação em 48 horas, na qual não é prevista a participação do réu, que ainda não foi citado (art. 296, CPC). Assim, não havendo retratação pelo juiz, a apelação subirá ao Tribunal sem contrarrazões. Se por qualquer motivo o Tribunal der provimento à apelação, os autos, em regra, retornarão ao Juízo de primeira instância para que o réu seja então regularmente citado e tenha oportunidade de defesa ampla, não ocorrendo preclusão de matéria.

A apelação prevista no art. 285-A, $\S 1^{\circ}$, ao contrário do que ocorre com aquela prevista no art. 296 do CPC, é interposta em face de sentença que resolve o mérito do processo, ou seja, sentença com fundamento no art. 269, I, do CPC. O prazo para interposição do recurso foi ampliado para 5 dias. Prevê o $\S 2^{\circ}$ do referido artigo que mantida a sentença pelo juiz, será ordenada a citação do réu para responder ao recurso. Aqui, diferentemente do que ocorre com a apelação da sentença de indeferimento da petição inicial, a apelação não sobe sem contrarrazões.

Neste último caso, por opção legislativa, é dado ao juiz, percebendo que tem razão o recorrente em seu recurso - por constatar que a hipótese não era de julgamento prima facie do mérito, quer pela existência de matéria de fato a exigir dilação probatória ou, ainda, porque não há identidade entre os casos - retratar-se. Aqui, convencido do desacerto do julgado, caberá ao juiz tornar sem efeito a decisão, determinar a citação do réu e dar seguimento normal ao feito. ${ }^{278}$

A decisão de retratação pelo julgador pode ocorrer por simples despacho, inclusive no corpo do próprio despacho que recebeu a apelação. É decisão irrecorrível, pois inexiste interesse recursal para ambas as partes: o autor obteve o processamento da causa e o réu, após a citação, terá a oportunidade de se defender.

\footnotetext{
${ }^{278}$ Luís Guilherme Aidar Bondioli entende que "para a hipótese de reconsideração da sentença, nada mais precisava ter sido dito pelo legislador. Afinal, tal reconsideração retira do cenário jurídico a sentença liminar e o processo tramita daí em diante como se houvesse acabado de iniciar, como se nada houvesse acontecido anteriormente. Daí ser suficiente o comando para que o juiz simplesmente determine o prosseguimento da ação (art. 285-A, $\S 1^{o}$ )". (BONDIOLI, Luís Guilherme Aidar. Os embargos declaratórios sob a ótica da efetividade, cit., p. 16).
} 
Registre-se que o juízo de retratação não prevê a possibilidade de inversão do sentido do julgado, isto é, julgamento de procedência do pedido antes da citação do réu, devendo, como já salientamos, ser determinado o prosseguimento da ação, nos termos do disposto no 285-A, $\S 1^{\circ}$, do CPC. De outro lado, mantida a decisão, deverá ser processada a apelação, devendo ser citado o réu para responder ao recurso (285-A, $\S 2^{\circ}$, do CPC).

Por fim, é de se destacar o fato de que o dispositivo relativo à improcedência liminar do pedido, no projeto de novo CPC, não aborda a questão referente aos aspectos recursais em seu corpo, remetendo para o art. 306 (constante da Seção afeta ao indeferimento da petição inicial). Referido artigo, por sua vez, unifica o prazo para que juiz exerça o juízo de retratação, tanto no caso de indeferimento da inicial quanto no caso de julgamento de improcedência de plano, em 03 (três) dias.

\subsection{Citação}

Um dos pontos essenciais da redação do art. 285-A do CPC se refere justamente à previsão de dispensa da citação para julgamento de improcedência de plano do pedido inicial. Observa-se, assim, que é possível ao magistrado julgar improcedente o pedido, reproduzindo o julgado em que se baseou, sendo desnecessária a citação do réu, desde que se trate de questão unicamente de direito e haja prolação reiterada de sentenças julgando improcedentes os pedidos formulados em casos idênticos.

Somente será determinada a citação da parte contrária, num segundo momento, se houver a interposição de recurso, depois do juízo de retratação, mantendo-se ou não a sentença de improcedência ( $\S 1^{\circ}$ e $2^{\circ}$ do art. 285-A do CPC).

Conforme dispõe o artigo 213 do Código de Processo Civil, citação é “o ato pelo qual se chama a juízo o réu ou o interessado a fim de se defender". Trata-se, conforme se infere da dicção do dispositivo legal, de ato processual por intermédio do qual é oferecido ao réu ou terceiro conhecimento oficial acerca do teor da demanda, dando-lhe oportunidade de resposta, a qual pode incluir a defesa e também a possibilidade de deduzir uma pretensão. Assim, compõe-se a citação de dois elementos: a cientificação do inteiro teor da demanda e o chamamento do demandado para se manifestar nos autos, 
assegurando-se o direito à ampla defesa e ao contraditório, verdadeiros direitos e garantias individuais, previstos no artigo $5^{\circ}$, inciso LV, da Constituição Federal. ${ }^{279}$

A citação no direito processual brasileiro é ato judicial destinado, nos termos da lei, ao réu ou interessado, acarretando diversos efeitos para o processo, motivo pelo qual se faz necessário verificar quais as consequências de sua dispensa nos casos de julgamento proferido com fundamento no art. 285-A do CPC.

Cabe observar que na nova sistematização do julgamento de improcedência prima facie prevista no art. 307 do PL 8.046/10, o dispositivo pode levar o leitor mais desavisado a entender que há possibilidade de se fazer uso da técnica mesmo após a citação, já que sua redação se utiliza da locução "independentemente da citação do réu”, o que não se coaduna com o seu intento. Isto porque, citado o réu, não será mais hipótese de aplicação do chamado julgamento de improcedência liminar do pedido, restando ao juiz fazer uso do julgamento antecipado da lide, que no projeto do novo CPC passa a ser chamado julgamento imediato da lide, com previsão no art. 341.

A doutrina brasileira, baseada na teoria do processo como relação jurídica de Oskar Von Büllow, concebe o processo como relação jurídica processual trilateral, a qual não se confunde com a relação jurídica de direito material. ${ }^{280}$

Afirma-se, ainda, que o processo estaria condicionado à presença de certos pressupostos processuais, "elementos cuja presença é imprescindível para a existência e para a validade da relação processual e, de outra parte, cuja inexistência é imperativa para que a relação processual exista validamente, nos casos dos pressupostos processuais negativos". 281

De um modo geral, reconhece a doutrina ser a citação pressuposto processual. A divergência reside, todavia, em qual categoria deveria ser a mesma inserida. Há autores que entendem tratar-se de pressuposto processual de existência (condições imprescindíveis

\footnotetext{
${ }^{279}$ A propósito, esclarece André de Luizi Correia que “a citação é ato judicial que tem por finalidade comunicar ao sujeito passivo da relação processual (réu e litisconsortes passivos) ou aos interessados, que foi ajuizada demanda ou procedimento de jurisdição voluntária, a fim de que possam, querendo, vir se defender ou se manifestar, dando-se-lhes oportunidade, dessa forma, de exercer o fundamental direito ao contraditório (no caso do réu e litisconsortes passivos) ou o fundamental direito de ação (no caso dos interessados em integrar a lide)”. (CORREIA, André de Luizi. A citação no direito processual civil brasileiro. São Paulo: Ed. Revista dos Tribunais, 2001. p. 33).

${ }^{280}$ Por todos, confira-se: ALVIM, Arruda. Manual de direito processual civil. 13. ed. São Paulo: Ed. Revista dos Tribunais, 2010. p. 490.

${ }^{281}$ WAMBIER, Teresa Arruda Alvim. Nulidades do processo e da sentença. 6. ed. São Paulo: Ed. Revista dos Tribunais, 2007. p. 46.
} 
sem as quais o processo não poderia ser considerado existente no mundo jurídico), outros, pressuposto processual de validade do processo (necessário para o desenvolvimento regular do processo).

Arruda Alvim sistematiza os pressupostos processuais em pressupostos processuais de existência e de validade da relação jurídica processual, bem como em pressupostos processuais negativos. Para o autor, o art. 263 do CPC somente instaura o processo entre o juiz e o autor, sendo que a citação será a responsável pela formação da necessária relação triangular, sendo pois pressuposto de existência. ${ }^{282}$

Sob este ponto de vista, a citação, como pressuposto processual de existência, teria por função precípua “completar a relação jurídica processual, isto é, formar o processo”. ${ }^{283}$ Em outras palavras, convencionou-se ser a citação o elemento de integração da relação jurídica processual trilateral, momento a partir do qual estaria constituído o processo.

Para os defensores desta corrente, a citação constitui um pressuposto de existência, já que o processo só existirá se aperfeiçoada a relação jurídica triádica (formada pelo juiz, autor e réu). Há, argumentam, com a propositura da ação, apenas um início de relação processual que, ausente o ato citatório, não será integralizado. Corresponderia a citação, assim, a um pressuposto de existência do processo, sem o qual não será possível a "prestação da tutela jurisdicional plena", devendo ser extinto o feito sem resolução do mérito, nos termos do art. 267, IV, do CPC. ${ }^{284}$

Consequência desse raciocínio é que, condicionada a própria existência do processo ao ato citatório, sua ausência ensejará a inexistência de relação jurídica processual, bem como a impossibilidade de se produzir qualquer um dos efeitos mencionados no art. 219, do CPC. Ademais, a ausência dos pressupostos processuais bem como das condições da ação impediriam o magistrado de adentrar no mérito da ação.

\footnotetext{
${ }^{282}$ Dentre os pressupostos processuais de existência elenca a necessidade de demanda, a existência de jurisdição, bem como a efetivação da citação da parte contrária (apesar de incluir no rol a capacidade postulatória, o próprio autor aduz pensar que esta "situa-se fora dos quadros dos pressupostos processuais"). No tocante aos pressupostos de validade da relação processual, elenca a petição inicial regular, órgão competente ocupado por sujeito imparcial e a capacidade da parte. Na última categoria, dos pressupostos processuais negativos, inclui a litispendência e a coisa julgada. (ALVIM, Arruda. Manual de direito processual civil, cit., p. 491-500).

${ }^{283}$ CORREIA, André de Luizi. A citação no direito processual civil brasileiro. São Paulo: Ed. Revista dos Tribunais, 2001. p. 63. Também Teresa Arruda Alvim Wambier defende que a citação é pressuposto processual de existência. (WAMBIER, Teresa Arruda Alvim. Nulidades do processo e da sentença, cit., p. 53).

${ }^{284}$ RODRIGUES, Marcelo Abelha. Manual de direito processual: teoria geral: premissas e institutos fundamentais, relação jurídica; procedimentos em $1^{\circ}$ e $2^{\circ}$ graus; recursos; execução; tutela de urgência, cit., p. 164.
} 
De outra banda, há aqueles que defendem que a citação é um pressuposto processual de validade do processo, no sentido de que sem ela o processo não seria válido.

Antonio Cláudio da Costa Machado, nesse sentido, sustenta que a citação corresponde a um pressuposto processual de validade do processo, já que antes mesmo desta já existe relação processual, que somente não se desenvolverá validamente sem a citação. ${ }^{285}$

Há quem afirme que a citação não é um pressuposto processual e sim um requisito de validade dos atos processuais, além de condição de eficácia do processo em relação ao réu (art. 219 e 263 do CPC), uma vez que esta se dá em momento posterior à existência do processo. $^{286}$

Apoiam-se, para tanto, na dicção do artigo 214 do CPC que determina que é indispensável a citação do réu para a validade do processo, todavia, tanto a falta de citação quanto a sua nulidade ficam supridas caso o réu compareça e conteste a lide.

Defende José Roberto dos Santos Bedaque que dentre os diversos pressupostos de existência elencados pela doutrina o único que poderia ser considerado necessário para a existência do processo é a jurisdição. Os demais pressupostos, no seu sentir, são requisitos intrínsecos processuais necessários ao desenvolvimento regular do feito e que devem ser considerados no momento da análise da admissibilidade do exame do mérito. ${ }^{287}$

Concordamos com Luiz Guilherme Marinoni quando sustenta ser preciso repensar a finalidade de tais pressupostos. Isto porque tais requisitos não são pressupostos de existência ou de validade do processo, tampouco condição para o julgamento de mérito, e sim “condições para a concessão da tutela jurisdicional do direito”, sendo intimamente influenciados pelos interesses do Estado e das partes. ${ }^{288}$

Nesse sentido, a falta dos pressupostos processuais não configura empecilho para que seja proferida uma sentença meritória desde que a tutela jurisdicional do direito não seja contrária ao interesse público e que a sentença de mérito seja favorável àquela parte

\footnotetext{
${ }^{285}$ MACHADO, Antônio Cláudio da Costa. Código de Processo Civil interpretado e anotado: artigo por artigo, parágrafo por parágrafo. 4. ed. São Paulo: Manole, 2012. p. 510. Adotam este entendimento, entre outros, Milton Sanseverino e Roque Komatsu, em sua obra A citação no direito processual civil (São Paulo: Ed. Revista dos Tribunais, 1977. p. 105-106).

${ }^{286}$ Nesse sentido: DIDIER JÚNIOR, Fredie. Curso de direito processual civil: introdução ao direito processual civil e processo de conhecimento. 14. ed. Salvador: Ed. Juspodivm, 2012. v. 1. p. 493-494.

${ }^{287}$ BEDAQUE, José Roberto dos Santos. Efetividade do processo e técnica processual, cit., p. 212-214.

${ }^{288}$ MARINONI, Luiz Guilherme. Teoria geral do processo: curso de processo civil. 4. ed. rev. e atual. São Paulo: Ed. Revista dos Tribunais, 2010. v. 1, p. 482-484.
} 
cujo requisito faltante visava proteger. Portanto, só se justificaria a extinção do feito com fundamento no art. 267, IV, do CPC, quando não fosse possível aferir qual das partes possui razão no mérito. ${ }^{289}$

Percebe-se, assim, que o processo existirá e valerá independentemente de citação, sendo que sua ausência somente surtirá efeitos para o aperfeiçoamento da relação processual em face à parte que deveria ser citada e não o foi.

De fato, o processo surge com a propositura da ação (art. 263, do CPC), o que se dá antes de qualquer citação. ${ }^{290}$ Assim, com o despacho ou o protocolo para distribuição da petição inicial, o processo nasce e passa a ter vida independentemente de eventual e futura citação. Ainda que a petição inicial seja indeferida sem que ocorra citação, este indeferimento equivale a uma sentença de extinção, isto porque, processo existiu. A citação, assim, terá por função vincular a pessoa citada à relação processual, mas a sua ausência não é óbice para a formação da relação processual linear entre autor e juiz. ${ }^{291}$

Convém ressaltar a prescindibilidade da citação em determinadas hipóteses legais, fato que não desnatura a existência do processo. Com efeito, já vimos ser possível a existência do processo mesmo sem a citação da parte contrária, sendo possível, inclusive sua extinção sem julgamento do mérito. Resta-nos agora verificar se é possível o julgamento de mérito, bem como qual sua influência para o demandado, não citado.

O julgamento de mérito, antes da realização da citação do réu, não é novidade em nosso ordenamento, já que as normas dos arts. 295, IV e 269, IV, do CPC, já autorizavam ao magistrado a decidir pela extinção liminar do processo com decisão de mérito, sem citação do demandado, sempre que acolhesse a alegação de prescrição ou decadência.

Percebe-se que o julgamento com fundamento na norma do art. 285-A, do CPC encontra-se acorde com tal entendimento ao vislumbrar que o processo existirá e será

\footnotetext{
${ }^{289}$ Parece que nesse sentido nosso entendimento se coaduna com o de Ernane Fidélis dos Santos quando afirma que o processo tem por objetivo "dar efetivação ao direito material”, motivo pelo qual conclui que "se os fins da lei são alcançados, poderá haver até mesmo convalidação da falta de pressupostos processuais”. (SANTOS, Ernane Fidélis dos. Manual de direito processual civil: processo de conhecimento. 14. ed., cit., v. 1, p. 111).

${ }^{290}$ Aqui, se faz oportuna lição de José Roberto dos Santos Bedaque para quem "a concepção de processo como relação jurídica acaba servindo como justificativa para o formalismo”. (BEDAQUE, José Roberto dos Santos. Efetividade do processo e técnica processual, cit., p. 191).

${ }^{291}$ Também segue este entendimento Ernane Fidélis dos Santos: "Quando não se faz a citação, ou se esta for nula de pleno direito, o processo não é inexistente, conforme pretende alguns doutrinadores, porque a relação processual, embora defeituosa, pode formar-se angularmente, apenas entre autor e juiz. Neste caso, qualquer decisão que se profira terá eficácia e, transitando em julgado, a definitividade dos efeitos atinge somente o autor e não o réu." (SANTOS, Ernane Fidélis dos. Manual de direito processual civil: processo de conhecimento, cit., 14. ed., v. 1, p. 448).
} 
válido, sendo que apenas a relação processual que dele se formar não vinculará o réu naquilo que lhe for prejudicial.

Costuma-se apontar como problema decorrente da falta de angularização da relação jurídica processual a ignorância do demandado acerca de pronunciamento judicial que lhe é favorável. Todavia, tal alegação não deve ser acatada para afastar a aplicação do dispositivo, sendo que solução viável à espécie do art. 285-A seria adotar sistemática semelhante àquela prevista no art. $219, \S 6^{\circ}$, determinando a comunicação do resultado da sentença e do trânsito em julgado ao réu ${ }^{292}$. Tal necessidade, é bom ressaltar, já se faz presente na nova redação proposta pelo PL 8.046/10 (art. 307, $\S 2^{\circ}$ ).

Diante do exposto, inegável a existência de processo, bem como de julgamento meritório sem a presença do réu ou sem citação. Trata-se de hipótese excepcional, é bom salientar, em que a participação do réu se faz desnecessária, haja vista que a sentença proferida não lhe acarreta dano algum estando, ainda, em consonância com os princípios da economia processual e da instrumentalidade das formas.

Indo adiante, convém verificar como a dispensa ou, ainda, a transferência do momento do ato citatório (para depois do juízo de retratação, quando o magistrado manterá ou não a sentença de improcedência - $\S \S 1^{\circ}$ e $2^{\circ}$ do art. 285-A do CPC) interfere na produção dos efeitos processuais e materiais elencados no artigo 219, caput, da lei processual. $^{293}$

O primeiro efeito processual decorrente da citação é tornar prevento o Juízo, o que significa dizer que ocorre a fixação de competência para que um único juízo, dentre outros igualmente competentes, possa decidir demandas conexas ou continentes.

\footnotetext{
${ }^{292}$ Nesse sentido, trazemos a baila ensinamento de Luís Guilherme Aidar Bondioli: "No encerramento deste tópico, registra-se que mesmo que o réu não venha a ser integrado à relação jurídica processual, em razão de o autor não se insurgir contra a sentença liminar e o feito efetivamente se encerrar, ele não deve permanecer alheio aos acontecimentos do processo. Nesses casos, ele deve ser comunicado do resultado do julgamento pelo escrivão (aplicação analógica do art. $219, \S 6^{\circ}$ ), a fim de que tenha ciência do reconhecimento de seu direito em juízo e o faça valer, inclusive, para se defender de futuras investidas judiciais do autor". (BONDIOLI, Luís Guilherme Aidar. O julgamento liminar de improcedência da demanda da óptica do réu (art. 285-A do CPC), cit., p. 15).

${ }^{293} \mathrm{O}$ art. 219, caput, do CPC estabelece que “A citação válida torna prevento o juízo, induz litispendência e faz litigiosa a coisa; $e$, ainda, quando ordenada por juiz incompetente, constitui em mora o devedor $e$ interrompe a prescrição”. Milton Sanseverino e Roque Komatsu acrescentam a estes uma série de outros efeitos na esfera processual, tais como: "impede a modificação do pedido ou da causa de pedir (art. 264, $1^{a}$ parte); acarreta a estabilização das partes, que só podem ser substituídas nos casos permitidos em lei (art. 264, $2^{a}$ parte); estabelece o termo a quo do prazo para resposta ou embargos (arts. 297 e 241, combinados; arts. 738, n. IV; 802, parágrafo único, n. I etc), completa a relação processual, que se iniciara com a ação proposta pelo autor (art. 263, $1^{a}$ parte), tornando o processo apto a desenvolver-se validamente (art. 214)". (SANSEVERINO, Milton; KOMATSU, Roque. A citação no direito processual civil. São Paulo: Ed. Revista dos Tribunais, 1977. p. 115).
} 
O julgamento proferido pelo magistrado com observância do disposto no art. 285-A do CPC implicará na ausência de prevenção do juízo, que ficará condicionada à determinação para citação do réu (magistrados coma a mesma competência territorial) ou, ainda, à ocorrência da efetiva citação do réu (nos casos de juízes de comarcas distintas) advindas da interposição do recurso de apelação pelo autor. ${ }^{294}$ Ainda que seja interposto o recurso de apelação, bem como sobrevenha prevenção do Juízo, o magistrado somente poderá se utilizar da faculdade de reunião de demandas na hipótese em que exercer o juízo de retratação, já que caso mantenha sua decisão, a fase avançada de tal ação (recursal) em relação à outra será considerada um empecilho para tanto.

Outro efeito processual é a possibilidade de induzir litispendência, ou seja, estando em trâmite ações idênticas (mesmas partes, pedido e causa de pedir), em juízos distintos, surge a possibilidade de extinção da ação que teve o seu início por último.

Como já tivemos oportunidade de afirmar, o processo existirá antes da citação, desde a propositura da ação. Seguindo tal raciocínio, o mesmo deve ocorrer no tocante à litispendência, procurando-se afastar a reprodução de demandas idênticas. É claro que desconhecendo a existência da demanda o réu não poderá, num primeiro instante, articular referida objeção. Contudo, trata-se de matéria que pode ser conhecida até mesmo de ofício pelo magistrado.

Diz-se, ainda, que a citação torna litigiosa a coisa, isto é, em sendo o bem infungível, a citação válida "o vincula definitivamente ao processo e seu resultado" ${ }^{295}$ Assim, o bem jurídico objeto do litígio perpetrado pelas partes passa a ser litigioso, sendo que qualquer alteração no estado da coisa sem prévia determinação judicial será considerada ilegal, podendo ensejar inclusive o pagamento de indenização.

Nos casos de julgamento de improcedência do pedido do autor realizado de plano, liminarmente, antes mesmo da citação do réu, temos que para o autor a litigiosidade da coisa surge tão logo proposta a demanda. No que diz respeito ao réu, "a partir desta citação para apresentação de contra-razões, eventual alienação do bem litigioso pelo demandado pode constituir fraude à execução (art. 593 do CPC.)” 296

\footnotetext{
${ }^{294}$ DONOSO, Denis. Julgamento prévio do mérito: análise do art. 285-A do CPC, cit., p. 162-163.

${ }^{295}$ GRECO FILHO, Vicente. Direito processual civil brasileiro. 19. ed. São Paulo: Saraiva, 2008. v. 2, p. 37.

${ }^{296}$ GAJARDONI, Fernando da Fonseca. O princípio constitucional da tutela jurisdicional sem dilações indevidas e o julgamento antecipadíssimo da lide, cit., p. 170.
} 
Entre os efeitos da citação encontram-se também efeitos materiais, que influem diretamente na relação jurídica material discutida no feito. $O$ primeiro deles é a constituição em mora do devedor, nos casos de obrigações sem vencimento certo, bem como naquelas em que é necessária a notificação prévia do devedor (mora “ex persona”). Dentre as consequências da mora do devedor tem-se, por exemplo, a responsabilização pelos danos causados (art. 395, Código Civil) e a possibilidade de rejeição, pelo credor, do cumprimento da prestação, se por causa da mora ela se tornou inútil ou perdeu seu valor (art. 395, parágrafo único, Código Civil).

Quando a dívida é declarada no próprio processo, o devedor fica em mora a partir da citação. Nesse ponto, em sendo a sentença proferida com fundamento no art. 285-A, isto é, de improcedência do pedido, não parece haver maiores implicações a ausência da citação.

Contudo, merece maior atenção o fato do autor se valer do direito de apelar do julgamento prévio de improcedência, já que com este surgirá a possibilidade de que o réu venha a perder a demanda, devendo, assim, arcar com os efeitos da mora. Esta incidirá, a nosso ver, a partir da citação do réu, seja na hipótese em que o juiz se retratar, retomando o curso normal do processo com citação para resposta e demais atos ou, ainda, mantiver sua decisão, determinando a citação do réu para responder ao recurso.

O segundo efeito material descrito no art. 219 é no sentido de que a citação faz interromper a prescrição. Ressalte-se que atualmente entende-se ser necessária a análise conjunta do art. 219, $\S 1^{\circ}$, do CPC com o art. 202, I, do Código Civil. Deste modo, se a parte promover a citação nos termos do art. 219 e seguintes do CPC, a interrupção da prescrição ocorrerá desde o despacho do juiz (art. 202, I, do CC) e a interrupção da prescrição retroagirá à data da propositura da ação (art. 219, §1 $\left.{ }^{\circ}, \mathrm{CPC}\right) .{ }^{297}$

A retroação dos efeitos da prescrição tem por finalidade impedir que a pretensão formulada prescreva por razões alheias à vontade do demandante, uma vez que este, uma

\footnotetext{
${ }^{297}$ Esse entendimento restou consolidado a partir da publicação do Enunciado no 417 da V Jornada de Direito Civil do Conselho da Justiça Federal, o qual possui a seguinte redação: “ $O$ art. 202, I, do CC deve ser interpretado sistematicamente com o art. 219, $\$ 1^{o}$, do CPC, de modo a se entender que o efeito interruptivo da prescrição produzido pelo despacho que ordena a citação é retroativo até a data da propositura da demanda". Há, contudo, entendimento no sentido de que no caso do art. 285-A do CPC, deve-se entender que a prescrição se interrompeu com a prolação da própria sentença. (CUNHA, Leonardo José Carneiro da. Primeiras impressões sobre o art. 285-A do CPC (julgamento imediato de processos repetitivos: uma racionalização para as demandas de massa), cit., p. 104.
} 
vez proposta a ação, não tem como fazer o controle dos atos processuais e do tempo em que serão praticados.

$\mathrm{O}$ art. 285-A do CPC, que autoriza a prolação de sentença de improcedência sem a prévia oitiva da parte contrária, prevê em seu $\S 2^{\circ}$ que será determinada, caso mantida a sentença pelo Juízo "a quo", a citação do réu para responder ao recurso de apelação. É a partir deste despacho, desde que a citação se realize validamente, que será interrompido o prazo prescricional. ${ }^{298}$

Além de todas essas implicações, a citação da parte contrária, nos casos em que houver recurso do autor em face da sentença proferida nos termos do art. 285-A do CPC, possibilitará ao Tribunal, como veremos adiante, a análise do mérito do pedido nos termos do art. 515 do CPC, evitando o retorno dos autos ao Juízo de origem para a prolação da sentença de mérito, em obediência aos princípios da celeridade e economia processual.

Citado, pessoalmente, para responder ao recurso, o réu deverá contratar advogado para representá-lo, visto ser imperativa a necessidade de representação por profissional habilitado nos tribunais e também nas turmas recursais dos Juizados. Caso o réu vencedor não seja localizado para citação pessoal, será o caso de citação ficta, cabendo inclusive nomeação de defensor, a fim de se evitar futura alegação de nulidade por afronta às garantias do devido processo legal. ${ }^{299}$

\subsection{Natureza jurídica da resposta do réu}

A sentença de improcedência proferida liminarmente é de natureza meritória, isto é, resolve a questão com resolução do mérito (art. 269, I, do CPC), comportando, como visto, a interposição de recurso de apelação. ${ }^{300}$

No mesmo sentido do que já era previsto para a hipótese de indeferimento da inicial (art. 296 do CPC), havendo recurso da parte autora contra o pronunciamento do juiz, ao

\footnotetext{
${ }^{298}$ Cf. DONOSO, Denis. Julgamento prévio do mérito: análise do art. 285-A do CPC, cit., p. 184.

${ }^{299}$ MARCATO, Antonio Carlos. Considerações sobre o julgamento de causas repetitivas. Disponível em <http://www.cartaforense.com.br/conteudo/artigos/consideracoes-sobre-o-julgamento-de-causasrepetitivas/4509>. Acesso em: 13 maio 2009.

${ }^{300}$ Ressalva feita anteriormente aos casos de julgamento de improcedência liminar tão somente com relação a um dos pedidos quando houver cumulação de pretensões pelo autor em que considerável parcela da doutrina entende a natureza do ato do juiz será de decisão e o recurso cabível o de agravo de instrumento.
} 
juízo será oportunizado retratar-se. Caso haja a retratação, haverá a citação do réu para prosseguimento da ação em seus regulares termos.

Em não havendo retratação, ou seja, mantida a sentença, o juiz determinará a citação do réu para responder ao recurso (art. 285-A, $\S 2^{\circ}$, do CPC), previsão que se mantém no art. 306, $\S 1^{\circ}$, do PL 8.046/10, como mecanismo que assegura ao demandado vencedor a plenitude de defesa, e garante ao mesmo que, se mantido o entendimento pelo Tribunal, possa se resguardar de eventual inconveniente como o ajuizamento de nova ação pelo réu, no mesmo ou em outro juízo, invocando os efeitos da coisa julgada. ${ }^{301}$

Questão controversa refere-se à definição da natureza jurídica da resposta que o réu citado apresentará (pessoalmente ou por defensor). Contudo, parece prevalecer na doutrina o entendimento de que as contrarrazões ao recurso de apelação terão natureza jurídica de contestação. ${ }^{302}$

Acompanhando tal entendimento, Fernando da Fonseca Gajardoni faz as seguintes ponderações:

Deverá o réu, portanto, antecipar sua defesa de direito para este momento
(princípio da eventualidade), com a reserva de oportunamente impugnar e
provar matéria fática nos casos em que o tribunal a entender necessária,
com anulação da sentença liminar indevidamente proferida. Também é
nesta fase que poderão ser juntados documentos com o propósito de
corroborar o entendimento do juízo sobre o caso (julgados no mesmo
sentido, documentos a confirmar a impressão já obtida pelo magistrado
com a análise dos documentos liminarmente apresentados pelo autor,
etc.). ${ }^{303}$

As contrarrazões de apelação, que funcionam também como contestação ${ }^{304}$, configuram a primeira oportunidade do réu para se pronunciar no processo e opor-se à pretensão deduzida pelo autor, motivo pelo qual deve o réu se atentar não apenas em reforçar a sentença proferida em seu favor, a qual pode não subsistir, como também em

\footnotetext{
${ }^{301}$ PELEJA JÚNIOR, Antônio Veloso. Reformas do Código de Processo Civil e novos mecanismos de acesso à justiça. Curitiba: Juruá, 2010. p.152.

${ }^{302}$ Flávio Cheim, Fredie Didier e Marcelo Abelha Rodrigues, por exemplo, sustentam que as contrarrazões "terão conteúdo muito semelhante ao de uma contestação, uma vez que se trata de sua primeira manifestação. Além disso, o réu defenderá a sentença, reforçando a argumentação do magistrado”. (JORGE, Flávio Cheim; DIDIER JR., Fredie; RODRIGUES, Marcelo Abelha. A terceira etapa da reforma processual civil, comentários às leis 11.187 e 11.232, de 2005; 11.276, 11.277 e 11.280, de 2006. São Paulo: Saraiva, 2006. p. 59).

${ }^{303}$ GAJARDONI, Fernando da Fonseca. O princípio constitucional da tutela jurisdicional sem dilações indevidas e o julgamento antecipadíssimo da lide, cit., p. 171.

${ }^{304}$ AI 00294712720094030000, DESEMBARGADOR FEDERAL NERY JUNIOR, TRF3 - TERCEIRA TURMA, e-DJF3 Judicial 1 DATA:18/10/2010 PÁGINA: 373..FONTE_REPUBLICACAO.
} 
trazer novos dados e informações que impliquem na improcedência com novos fundamentos ou, ainda, na extinção do feito sem julgamento do mérito.

Esse posicionamento, contudo, não é unânime, havendo aqueles que entendem, ao nosso sentir de forma equivocada, que as contrarrazões do recurso de apelação não podem ser recebidas como se contestação fosse, sob o fundamento de que não incidiria sobre esta a regra da eventualidade, uma vez que o demandado ao responder ao apelo se detém ao objeto do recurso. $^{305}$

De opinião semelhante, Vicente de Paula Ataíde Júnior assevera que a citação será apenas para apresentar contrarrazões e não para contestar, não implicando a ausência de resposta do réu em revelia, tampouco confissão ficta, uma vez que provido o recurso, os autos retornarão à origem onde então será oportunizada apresentação de defesa. ${ }^{306}$

Entendemos que o réu deve ter cautela no momento de elaboração de sua contrarrazões, tendo em vista a existência do efeito devolutivo da apelação, que outorga expressiva margem de atuação para o tribunal no julgamento do apelo. ${ }^{307}$

Imperioso ressaltar, por fim, a falta de interesse do réu para recorrer de forma adesiva (art. 500) da sentença liminar de improcedência, uma vez que em $1^{\circ}$ grau a sentença negou tudo o que o autor pleiteou em face dele.

Já afirmamos que as contrarrazões de apelação do réu desempenham o papel da contestação, cabe verificar, agora, a possibilidade de utilização das demais modalidades de resposta (levando em consideração seu tríplice significado: contestação, exceção e reconvenção).

As exceções são uma modalidade especial de defesa, pois não atacam diretamente o direito, mas apenas embaraçam o seu exercício e podem ter natureza processual ou material ${ }^{308}$.

\footnotetext{
${ }^{305}$ PINTO, Fernanda Guedes. As ações repetitivas e o novel art. 285-A do CPC (racionalização para as demandas de massa), cit., p. 148.

${ }^{306}$ ATAÍDE JÚNIOR, Vicente de Paula. A resolução antecipada do mérito em ações repetitivas (lei 11277/2006), cit., p. 124.

${ }^{307}$ A corroborar o que se está a dizer, confira-se: "entendendo-se a resposta do réu como contestação, poderá o tribunal, ao reformar a sentença, julgar desde logo o mérito, aplicando, por analogia, o disposto no art. 515, parágrafo $3^{\circ}$, do CPC, o que nos parece extremamente benéfico ao sistema e atende aos princípios da celeridade e da razoável duração do processo." (SANT'ANNA, Paulo Afonso de Souza. Ações repetitivas e julgamento liminar (art. 285-A do CPC), cit., p. 111).

308 "São exemplos de exceções substanciais: a) de retenção; b) a de prescrição; c) a de contrato nãocumprido (exceptio non adimpleti contractus); d) ou de contrato mal cumprido (excpetio non rite adimpleti contractus); e) a de compensação”. (SILVA, Ovídio A. Baptista da. Curso de processo civil: processo de conhecimento, cit., v. 1, p. 304).
} 
O Código de Processo Civil, em seu art. 304, usa a expressão exceção em sentido muito peculiar, restringindo a expressão a três específicas defesas processuais: exceções de incompetência relativa, de suspeição e de impedimento. Esses três incidentes processuais serão apresentados pelas partes independentemente do mérito da demanda sendo que, uma vez recebida a exceção, o feito deverá ser suspenso até seu julgamento (art. 306 do CPC). Pode o réu, sendo o caso, apresentar todas as três modalidades de exceção, usando para tanto todo o prazo da resposta.

Por meio da exceção de incompetência relativa, busca-se o encaminhamento do processo a outro órgão ou a outro julgador. Quem alega a incompetência tem que declinar qual o órgão entende ser competente para o julgamento da causa, sob pena de ficar prorrogado o foro.

As exceções de impedimento e de suspeição referem-se a vícios que atingem a pessoa do juiz, que por situação subjetiva se acha com a sua imparcialidade comprometida, nos termos dos arts. 134 a 135, do CPC. Tais exceções podem ser articuladas, a qualquer tempo, desde o conhecimento do fato, tanto pelo réu quanto pelo autor e têm por finalidade afastar um juiz da condução de um processo, mas sem interferir na competência do juízo. Desta forma, a procedência desses incidentes levará à convocação de outro magistrado. Nesses casos, ao magistrado não é dado extinguir a exceção, salvo se for para reconhecer a sua parcialidade.

É de se ressaltar que tanto a exceção de impedimento quanto a de suspeição podem ser arguidas em relação a membros dos tribunais seguindo, em tais hipóteses, o procedimento previsto nas normas regimentais.

No que toca à compatibilidade da arguição de exceções com a sistemática do art. 285-A do CPC, não verificamos óbice à sua apresentação pelo réu ${ }^{309}$.

Nos casos de suspeição ou impedimento, essas exceções deverão ser arguidas no prazo de quinze dias do conhecimento do fato que as gerar, devendo ser apresentada ao juiz, a quem caberá, de plano, avaliar a sua suspeição ou o seu impedimento.

\footnotetext{
${ }^{309}$ Concordamos, todavia, com Luís Guilherme Aidar Bondioli quando afirma: "No que diz respeito às exceções de suspeição, impedimento e incompetência relativa, é preciso considerar que por ocasião da integração do réu ao processo o juiz já encerrou o julgamento da causa e o fez de forma totalmente favorável ao demandado. Assim, parece fora de cogitação que a essa altura ele venha colocar em discussão a competência e a imparcialidade do juiz”. (BONDIOLI, Luís Guilherme Aidar. O julgamento liminar de improcedência da demanda da óptica do réu (art. 285-A do CPC), cit., p. 20).
} 
Reconhecendo o fundamento da exceção e, pois, seu comprometimento subjetivo, remeterá os autos ao juiz que for o competente para substituí-lo. ${ }^{310}$

Não reconhecendo a imparcialidade, o magistrado apresentará suas razões, encaminhando os autos da exceção à instância superior, que lá processará o incidente. Se o excipiente não tiver razão, a exceção será arquivada. Caso contrário, reconhecendo-se o impedimento ou a suspeição, o Tribunal condenará o juiz nas custas e os autos serão remetidos a seu substituto legal, que passará a atuar no caso. A nosso ver, a sentença anteriormente proferida pelo magistrado tido por suspeito ou impedido será nula, devendo outra ser proferida em seu lugar. ${ }^{311}$

A possibilidade de alegação de incompetência relativa do juiz traz a lume uma questão interessante, já que tem envergadura para interferir na designação do tribunal de segunda instância competente para apreciação do recurso de apelação.

Com efeito, a exceção de incompetência tem por objeto arguir a incompetência relativa do juízo determinada por critério territorial. Ocorre que a mudança do juiz relativamente incompetente pelo juiz competente pode implicar não apenas o deslocamento da causa para outro juízo, mas também para juízo vinculado a outro tribunal da federação.

Nesse sentido, não nos parece adequado o entendimento de que tal exceção deveria ser ventilada em sede de contrarrazões como forma de "barrar o decreto de procedência da demanda pelo tribunal", ao argumento de que deveria ser analisada somente caso o Tribunal decidisse não manter a sentença de primeiro grau. ${ }^{312}$

Concordamos, neste ponto, com o posicionamento no sentido de que o julgamento das contrarrazões deve estar atrelada à sorte que vier a ter a exceção. Assim, o acolhimento da exceção ensejará a remessa dos autos ao Tribunal competente que, ao julgar a apelação, poderá manter a sentença de primeiro grau (produzindo o chamado efeito susbstitutivo) ou, ainda, remeter os autos ao juízo de primeira instância tido por competente para novo julgamento. $^{313}$

\footnotetext{
${ }^{310}$ GRECO FILHO, Vicente. Direito processual civil brasileiro, cit., v. 2, p. 132.

${ }^{311}$ No mesmo sentido: DONOSO, Denis. Julgamento prévio do mérito: análise do art. 285-A do CPC, cit., p. 214.

${ }^{312}$ BONDIOLI, Luís Guilherme Aidar. O julgamento liminar de improcedência da demanda da óptica do réu (art. 285-A do CPC), cit., p. 20-21.

${ }^{313} \mathrm{Cf}$. DONOSO, Denis. Julgamento prévio do mérito: análise do art. 285-A do CPC, cit., p. 218.
} 
A reconvenção, em que pese não possua caráter defensivo, é uma das modalidades de resposta do réu. Caracteriza-se, nos termos do art. 315 do CPC, por ser uma forma de contra-ataque do réu que passará a ser também demandante, cumulando-se em um único processo dois pedidos em sentidos inversos: um do autor em relação ao réu; outro do réu em face do autor da ação originária. Vê-se, assim, que tal mecanismo faz ampliar a relação processual, exigindo, inclusive, dilação probatória.

Tratando-se de uma demanda em face do autor, deverá o réu observar em sua elaboração todas as condições e requisitos essenciais ao direito de ação, além da necessidade de mesma competência e procedimento das duas ações, bem como conexão com a ação principal ou com os fundamentos da defesa.

Embora a reconvenção não seja acessória à ação principal (a extinção do processo principal, por exemplo, não obsta o prosseguimento da reconvenção), a intenção do legislador foi possibilitar que pretensões mútuas e com fatores de proximidade sejam resolvidas simultaneamente. Deste modo, apesar de se exigir coerência no julgamento das duas demandas, nada obsta que sejam os dois pedidos (principal e reconvencional) julgados procedentes ou mesmo improcedentes.

Revela-se a reconvenção como uma faculdade para o réu, uma vez que, não exercido o direito de ação pelo réu nos mesmos autos, nada impede a sua propositura pelos caminhos habituais.

Cremos, diante das particularidades advindas com o sistema do julgamento de improcedência prima facie, que o mesmo não se compatibiliza com a utilização da via reconvencional pelo réu. Isto porque se a ideia da reconvenção é prestigiar a celeridade com o julgamento em conjunto de demandas e se este (o julgamento), no presente caso já ocorreu, há questões ritualísticas inconciliáveis ${ }^{314}$. Esse pensamento não traz prejuízo algum ao réu que poderá ajuizar demanda pelas vias normais, sendo o mesmo raciocínio aplicável à hipótese de pedido contraposto. ${ }^{315}$

\footnotetext{
${ }^{314}$ BONDIOLI, Luís Guilherme Aidar. O julgamento liminar de improcedência da demanda da óptica do réu (art. 285-A do CPC), cit., p. 19-20.

${ }^{315}$ DONOSO, Denis. Julgamento prévio do mérito: análise do art. 285-A do CPC, cit., p. 211.
} 


\subsection{Julgamento da apelação pelo tribunal e a possibilidade de julgamento per saltum do mérito (Art. 515, § 3, do CPC)}

Recapitulando o que foi visto até o presente momento, temos que a apelação será interposta perante o juízo a quo através de petição de interposição, a qual deverá demonstrar a cabimento do recurso e a presença dos pressupostos recursais, bem como a necessidade de provimento do recurso com o intuito de anular ou reformar a sentença.

Recebido o recurso e não sendo o caso de juízo de retratação previsto no $\S 1^{\circ}$ do art. 285-A, o juiz de primeiro grau determinará a citação do réu para apresentar resposta ao recurso, para depois remeter os autos ao tribunal competente para julgamento.

Neste ponto, emerge a importância de que em suas razões de apelação o autor tenha evidenciado de forma precisa os fundamentos de sua impugnação à sentença, eis que o art. 515 do CPC devolve ao órgão ad quem as questões suscitadas e discutidas no processo. Deve haver correlação entre o objeto do recurso e o julgamento proferido.

No que diz respeito à profundidade do efeito devolutivo, tem se que é permitido ao tribunal, ao analisar o recurso, se valer de todos os elementos que estavam disponíveis ao juiz ao proferir a sentença e relacionadas ao objeto da impugnação. Com a interposição de um recurso, são devolvidas ao Tribunal as questões suscitadas e discutidas, ainda que não tenham sido julgadas por inteiro, bem como todos os fundamentos do pedido e da defesa, ainda que o juiz tenha acolhido apenas um.

Admitida a apelação e encaminhado os autos ao juízo ad quem, haverá sua distribuição a um dos órgãos fracionários (câmara ou turma) do tribunal competente para julgamento, definindo-se desde logo um relator e um revisor. ${ }^{316} \mathrm{O}$ relator é o juiz que receberá os autos em primeiro lugar e que poderá, de acordo com nova redação dada ao art. 557 do CPC, julgar monocraticamente a apelação - decisão da qual cabe nova insurgência ao respectivo colegiado.

Com efeito, como já tivemos a oportunidade de salientar no presente trabalho, atualmente, o relator poderá fazer juízo de admissibilidade negativo do recurso (quando o recurso não é conhecido), provê-lo ou desprovê-lo.

\footnotetext{
${ }^{316}$ SILVA, Ovídio A. Baptista da. Curso de processo civil: processo de conhecimento, cit., v. 1, p. 415.
} 
O relator, não sendo o caso de declarar, desde logo, que o recurso não é conhecido, poderá, se for o caso, negar-lhe provimento se o mesmo for manifestamente improcedente ou estiver em confronto com súmula ou jurisprudência daquele tribunal, do STF ou do STJ.

Vale ressaltar que os poderes do relator são reduzidos quando pretender dar provimento ao recurso, sendo que deverá se restringir a evocar tão apenas súmula ou jurisprudência do STF ou STJ. Em todas as hipóteses, é bom lembrar, fica ressalvada a possibilidade de interposição de agravo, no prazo de cinco dias, ao órgão colegiado. Provido o agravo do art. 557, $\S 1^{\circ}$, o recurso original terá seu processamento ordinário. Do contrário, são cabíveis recursos especial e extraordinário, pois se trata de decisão final por parte do Tribunal.

Constatando o relator não ser o caso de aplicação do art. 557 do CPC, deverá encaminhar os autos para análise pelo revisor, a quem caberá pedir dia para julgamento. Designada a data para o julgamento do recurso, será feita sua publicação no diário oficial, podendo apelante e apelado produzir sustentação oral em referida data, logo após a leitura do relatório pelo relator.

Em sede recursal, o Tribunal poderá tomar as seguintes atitudes: a) confirmar a sentença; b) cassá-la por entender não ser aplicável o art. 285-A do CPC naquele caso, por falta de alguns de seus pressupostos; c) reformá-la.

No primeiro caso, em sendo confirmada a sentença de primeiro grau pelo órgão recursal, manter-se-á decisão de improcedência, ratificando-se a utilização da técnica do art. 285-A. Inconformado com tal decisão, surgirá para o autor a possibilidade de se valer, estando presentes os pressupostos legais, dos recursos excepcionais.

Na segunda hipótese, entendendo ser o caso de cassação da sentença por não ser aplicável o art. 285-A do CPC naquele caso (error in procedendo), deverá o Tribunal anular a sentença e remeter os autos ao juízo originário para que seja proferido novo julgamento. ${ }^{317}$

Destacamos que inova o $\S 2^{\circ}$, do art. 306, do Projeto de Lei $n^{\circ} 8.046 / 10$ ao prever que "sendo a sentença reformada pelo tribunal, o prazo para a contestação começará a correr a contar da intimação do retorno dos autos”. Tal possibilidade, em nosso sentir, só

\footnotetext{
${ }^{317}$ MONNERAT, Fábio Victor da Fonte. Primeiras aplicações do art. 285-A do CPC. Revista de Processo, São Paulo, v. 33 n. 157, p. 240, 2008.
} 
deve ocorrer naqueles casos em que o réu tenha restringindo o conteúdo de suas contrarrazões.

A terceira conduta possível pelo Tribunal, e a que merecerá uma análise mais detida por nossa parte tendo em vista a divergência que suscita, refere-se à possibilidade de reforma da sentença recorrida, quando seja constatada a existência de error in judicando, desde que constatada a presença dos requisitos especificados pelo art. $515, \S 3^{\circ}$ do CPC.

$\mathrm{O} \S 3^{\circ}$ do art. 515 do CPC foi acrescentado pela Lei n. $^{\circ} 10.352 / 2001^{318}$ e importou uma inovação para o direito processual civil brasileiro ao conferir competência ao Tribunal para apreciar a matéria impugnada e também o mérito da causa. Até então, o Tribunal, ao verificar o recurso interposto de uma sentença terminativa, se restringia a reformá-la, ou seja, exercia o juízo rescindente, com posterior remessa ao juiz para que este apreciasse o mérito.

A regra antes da inclusão de tal dispositivo era que o mérito da causa somente poderia ser apreciado pelo Tribunal se o magistrado de primeira instância já o tivesse apreciado, isto é, o Tribunal não poderia decidir mais do que foi decidido pelo juízo originário, sob o fundamento de que estaria usurpando atribuição deste. ${ }^{319}$

O ingresso do parágrafo $3^{\circ}$ no art. 515 rompeu com antiga tradição relacionada com o princípio do duplo grau de jurisdição, uma vez que provida a apelação contra sentença meramente terminativa, a decisão do Tribunal não se restringirá à desconstituição do julgado e remessa dos autos ao juízo a quo que ficaria responsável por proferir nova sentença. Com efeito, hoje, presentes os requisitos legais, fica o órgão ad quem autorizado a desconstituir o julgado e adentrar no mérito, resolvendo a demanda, sem que seja necessário devolver os autos à primeira instância.

Diverge-se a respeito da possibilidade de aplicação conjunta do disposto nos arts. 285A e $515, \S 3^{\circ}$ do CPC, alegando aqueles contrários a tal sistemática que o chamado julgamento per saltum do tribunal só seria aplicável nos casos de sentenças terminativas e não nas sentenças definitivas como é o caso da sentença proferida com fulcro no art. 285-A.

De fato, da leitura do artigo tem-se que a possibilidade do julgamento per saltum diz respeito, a priori, à apelação contra sentença meramente terminativa (há menção

\footnotetext{
${ }^{318} \mathrm{O} \S 3 .^{\circ}$ do art. 515 possui a seguinte redação: "Nos casos de extinção do processo sem julgamento do mérito (art.267), o tribunal pode julgar desde logo a lide, se a causa versar questão exclusivamente de direito e estiver em condições de imediato julgamento".

${ }^{319}$ JORGE, Flávio Cheim. Teoria geral dos recursos cíveis, cit., p. 307.
} 
expressa ao artigo 267), desde que o encerramento do processo tenha sido indevido, a causa verse sobre questão exclusivamente de direito e esteja em condições de ser julgada no mérito.

Ao que parece, a alteração legislativa teve por intuito a celeridade na entrega da prestação jurisdicional, motivo pelo qual não vislumbramos óbice à possibilidade do julgamento per saltum de sentença de mérito, nos casos em que o tribunal houvesse de anular o pronunciamento final.

$\mathrm{O}$ artigo 285-A, conforme noticiado ao longo do presente trabalho, tem por escopo abreviar o procedimento em primeira instância em virtude da existência de entendimento reiterado do juízo acerca da questão unicamente de direito. Os dois dispositivos legais, portanto, perseguem finalidades semelhantes: a racionalidade e celeridade dos julgamentos.

Daí ser correto sustentar-se, segundo pensamos, que verificado pelo Tribunal que a causa encontra-se em condições de ser julgada, já que o réu foi devidamente citado, sendolhe concedida a oportunidade de se defender, e versando a causa sobre matéria de direito, não haverá óbice à aplicação do disposto no novel $\S 3^{\circ}$, do artigo 515 , do Código de Processo Civil, ainda que nos casos de prolação de sentença de mérito com esteio no art. $285-$ A. $^{320}$

Nessa esteira, revela-se de suma importância que tenha ocorrido a citação do réu para apresentação de resposta, e que nesta tenha a parte deduzido toda matéria de defesa, visando reforçar o convencimento de que o pleito do autor não merece prosperar. ${ }^{321}$ Para aqueles que entendem ser necessária a citação do réu com as advertências do art. 285, 2a parte do CPC, acompanha-se a proposta de Denis Donoso no sentido de que, na sua ausência, poderá o Tribunal avisar às partes sua intenção de aplicar o dispositivo legal, oportunizando-lhes manifestação, a teor do que consta no art. $515, \S 4^{\circ}$ do CPC. ${ }^{322}$

\footnotetext{
${ }^{320}$ Cf. MONNERAT, Fábio Victor da Fonte. Primeiras aplicações do art. 285-A do CPC. Revista de Processo - v. 33 n. 157 mar. 2008. São Paulo: Ed. Revista dos Tribunais, 2008, p. 241.

${ }^{321}$ À semelhante conclusão parece ter chegado Patrícia Carla de Deus Lima quando sustenta que "admitindose que o tribunal poderá, no mérito, julgar a apelação do art. 285-A, julgando procedente o pedido se não concordar com o entendimento exposto pelo juízo de primeiro grau, há de reconhecer que, para seu próprio bem, o réu deve, na resposta, aduzir toda matéria de defesa, com o intuito de formar convencimento a si favorável pelo juízo de segundo grau". (LIMA, Patrícia Carla de Deus. Notas sobre o julgamento da apelação do art. 285-A do CPC. In: NERY JÚNIOR, Nelson; WAMBIER, Teresa Arruda Alvim (Coord.). Aspectos polêmicos e atuais dos recursos cíveis e assuntos afins. São Paulo: Ed. Revista dos Tribunais, 2007. v. 11, p. 275).

${ }^{322}$ DONOSO, Denis. Julgamento prévio do mérito: análise do art. 285-A do CPC, cit., p. 224.
} 
Nem se argumente que tal sistemática violaria o princípio do duplo grau de jurisdição por não permitir que o juízo de origem se manifeste sobre o mérito da causa ${ }^{323}$. Com efeito, em que pese existirem aqueles que pugnam pelo seu perfil constitucional, não há previsão explícita e ilimitada do duplo grau de jurisdição na $\mathrm{CF} / 88$, que apenas prevê o respeito ao devido processo legal e ao contraditório, que agasalham, como ideia geral, a recorribilidade das decisões de mérito. ${ }^{324}$

Rui Portanova promove uma abordagem separada do princípio do duplo grau de jurisdição e o princípio da recursividade, por entender que este último possui maior abrangência. Ressalta o autor que "nosso sistema recursal admite hipóteses onde há recurso, mas não propriamente para um outro grau de jurisdição". ${ }^{325}$

Não vislumbramos a necessidade de o apelante formular, em suas razões recursais, pedido expresso de julgamento da lide pelo órgão ad quem caso a sentença seja reformada $^{326}$, já que o Tribunal poderá adentrar o mérito independentemente de requerimento da parte. Apesar de tal conduta poder ser considerada como supressão de instância, convém salientar que o duplo grau de jurisdicional não encontra guarida constitucional, não havendo prejuízo às partes.

Por fim, convém destacar que o novo CPC mantém a permissão aos tribunais de adentrarem na análise do mérito da causa, desde que se trate de questão exclusivamente de direito e esteja, o processo, em condições de imediato julgamento. Da leitura do art. 965, $\S$ $3^{\circ}$, do PL 8.046/10, conclusão que nos parece inevitável é que houve ampliação das hipóteses de cabimento da técnica, havendo, inclusive, previsão textual de que o tribunal deverá resolver desde logo a lide quando "reformar sentença que reconhecer a decadência os prescrição" (prevista no novo CPC como uma das hipóteses de incidência do julgamento de improcedência liminar do pedido).

\footnotetext{
${ }^{323}$ SÁ, Djanira Maria Radamés de; PIMENTA, Haroldo. Reflexões iniciais sobre o art. 285-A do Código de Processo Civil, cit., p. 142.

${ }^{324}$ Importante, nesse sentido, os ensinamentos de Oreste Nestor de Souza Laspro para quem "o duplo grau de jurisdição não é garantido no direito brasileiro a nível constitucional, estando somente regulado a nível ordinário". (LASPRO, Oreste Nestor de Souza. Duplo grau de jurisdição no direito processual civil. São Paulo: Ed. Revista dos Tribunais, 1995. p. 159).

${ }^{325}$ PORTANOVA, Rui. Princípios do processo civil. 6. ed. Porto Alegre: Livr. do Advogado, 2005. p. 106.

${ }^{326} \mathrm{Em}$ sentido contrário, adverte Flávio Cheim Jorge que "se por um lado, existe atualmente a necessidade de se reconhecer uma ampliação da extensão do efeito devolutivo, por outro, é inegável que a fixação da apreciação da matéria não foi retirada do poder dispositivo das partes". (JORGE, Flávio Cheim. Teoria geral dos recursos cíveis, cit., p. 308).
} 


\subsubsection{A reforma da decisão e o princípio da proibição da reformatio in pejus}

O princípio da vedação da reformatio in pejus possui estreita relação com o efeito devolutivo dos recursos, que significa que o tribunal (ou o próprio juízo recorrido, nas excepcionais hipóteses de juízo de retratação) apreciará o recurso nos limites em que proposto: tantum devolutum quantum apellatum. Em outros dizeres, só o que foi objeto de impugnação pode ser revisto.

Há dois sistemas distintos referentes ao efeito devolutivo dos recursos: sistema de proibição da reformatio in pejus e sistema do benefício comum (communio remedii). No primeiro caso, veda-se a piora na posição do recorrente em razão do julgamento de seu recurso, enquanto que no segundo propugna-se que o recurso interposto favorece ambas as partes, sendo tolerado que ocorra piora na posição do recorrente em virtude da apreciação de seu próprio recurso. ${ }^{327}$

Hoje, ainda que inexista previsão expressa no ordenamento vigente, extrai-se o princípio da proibição da reformatio in pejus mediante a interpretação sistemática das regras recursais, em especial do princípio dispositivo. ${ }^{328}$

Por meio de princípio da proibição da reforma para pior veda-se que o julgamento do recurso importe num resultado exatamente contrário àquele pretendido pelo recorrente, consistente na obtenção de uma situação mais confortável. ${ }^{329}$

Costuma-se apontar para a existência de duas espécies de reformatio in pejus, a qualitativa e a quantitativa. A primeira refere-se aos casos "de troca no fundamento da sentença impugnada em desfavor do apelante”, enquanto que a diferença para pior quantitativa "decorre do julgamento que retira algo do recorrente ou agrava-lhe a posição”. 330

\footnotetext{
${ }^{327}$ NEVES, Daniel Amorim Assumpção. Manual de direito processual civil, cit., p. 526.

${ }^{328}$ ASSIS, Araken de. Manual dos recursos, cit., p. 104.

${ }^{329}$ Conforme enfatiza Nelson Nery Júnior, "a proibição da reformação in pejus tem por objetivo evitar que o tribunal destinatário do recurso possa decidir de modo a piorar a situação do recorrente, ou porque extrapole o âmbito de devolutividade fixado com a interposição do recurso, ou, ainda, em virtude não haver recurso da parte contrária". (NERY JÚNIOR, Nelson. Princípios fundamentais: teoria geral dos recursos, cit., p. 153).

${ }^{330} \mathrm{Cf}$. ASSIS, Araken de. Manual dos recursos, cit., p. 106.
} 
Dois são os requisitos necessários para a ocorrência de reformatio in pejus: sucumbência recíproca e recurso de somente uma das partes. ${ }^{331}$

$\mathrm{O}$ primeiro requisito (sucumbência recíproca) refere-se à necessidade de demonstração da situação de desvantagem que a sentença produziu para ambas as partes (se houver uma sucumbência integral, o que sucumbiu não tem, em regra, como ter sua situação alterada para pior).

No tocante ao segundo requisito, recurso só de uma das partes, quer se dizer que sendo recurso de ambas as partes, o que prejudica a parte não é o seu recurso, e sim o recurso do adversário.

A reformatio in pejus é admitida excepcionalmente em algumas situações, tais como a aplicação do efeito translativo dos recursos, que se refere à possibilidade que o tribunal tem de reconhecer mesmo que de ofício as matérias de ordem pública ${ }^{332}$, bem como na hipótese de aplicação da teoria da causa madura (art. $\left.515, \S 3^{\circ} \mathrm{CPC}\right) .{ }^{333}$

Quando ocorre o julgamento do processo com fundamento no permissivo do art. 285-A do CPC, é descabida a fixação de honorários advocatícios, por ausência de citação do réu. Esclarece Fernando da Fonseca Gajardoni que “como o demandado não constituirá advogado neste primeiro momento, obviamente não há espaço para que o autor seja condenado ao pagamento de honorários advocatícios da parte ex adversa, embora a norma seja silente a este respeito". 334

Interposta apelação por parte do autor, os autos serão conclusos, facultando-se ao magistrado, no prazo de 5 (cinco) dias, reconsiderar sua decisão. Se o juiz mantiver a decisão, antes de determinar a subida dos autos, mandará citar o réu para responder ao recurso. Importante ressaltar que a citação deverá ocorrer também na hipótese do juízo retratar-se de sua decisão, recebendo a petição inicial.

Havendo a retratação, o que deve ocorrer de forma fundamentada, o réu se integra à relação jurídica processual nos mesmos moldes em que ocorre em todo e qualquer

\footnotetext{
${ }^{331}$ NEVES, Daniel Amorim Assumpção. Manual de direito processual civil, cit., p. 527.

${ }^{332}$ NERY JÚNIOR, Nelson. Princípios fundamentais: teoria geral dos recursos, cit., p. 153.

${ }^{333}$ No tocante à aplicação da teoria da causa madura, confira-se comentário de Araken de Assis: "Interposta apelação contra sentença terminativa (art. 267), o art. 515, $\$ 3^{\circ}$, autoriza, sob certas condições, o tribunal a superar o obstáculo e apreciar diretamente o mérito. Tal extensão dependerá de pedido do apelante. É bem possível que, ingressando no mérito, o tribunal julgue improcedente o pedido, criando situação mais desvantajosa para o recorrente. Cuidar-se-á, portanto, de outra hipótese de reformatio in pejus autorizada”. (ASSIS, Araken de. Manual dos recursos, cit., p. 112).

${ }^{334}$ GAJARDONI, Fernando da Fonseca. O princípio constitucional da tutela jurisdicional sem dilações indevidas e o julgamento antecipadíssimo da lide, cit., p. 168.
} 
processo, com a possibilidade de se utilizar de todos os mecanismos que o nosso ordenamento prevê.

Chegando o feito ao Tribunal, a este surgem as possibilidades vistas acima: manutenção da decisão de primeira instância, provimento à apelação para determinar o retorno do processo e seu prosseguimento em primeiro grau ou, ainda, provimento à apelação e reforma do julgado.

Improvido ou não conhecido o recurso pelo Tribunal, caso o réu tenha se habilitado na causa, contratando advogado para tanto, indaga-se se seria possível a condenação do autor ao pagamento de honorários advocatícios.

Em sendo positiva esta primeira indagação, questiona-se se isso encontraria óbice no princípio da proibição da reformatio in pejus. Isto porque, mantida a sentença do juízo $a$ quo pelo órgão ad quem, o recorrente terá piorado sua situação, pois, além de manter seu pedido com um julgamento de improcedência, deverá, ainda, arcar com o pagamento de honorários advocatícios ao demandado.

Fernando da Fonseca Gajardoni defende que pode o Tribunal manter a sentença de improcedência liminar e condenar o apelante "ao pagamento das verbas sucumbenciais, inclusive honorários do advogado, já que, tendo o réu sido citado, e tendo apresentado defesa por advogado (caso contrário não se imporá tal verba), incide o disposto no art. 20, $\$$ do $C P C ”, 335$

Entendimento semelhante, e do qual perfilhamos, é no sentido de que ao condenar o autor - apelante - ao pagamento de honorários o Tribunal " $n$ ão profere julgamento extra petitia, nem viola o princípio da reformatio in pejus, porque se trata de questão posterior à sentença, já que a citação se impôs em razão do recurso, e que, por isto, não poderia integrar o âmbito de devolutividade da apelação". ${ }^{336}$

\footnotetext{
${ }^{335}$ GAJARDONI, Fernando da Fonseca. O princípio constitucional da tutela jurisdicional sem dilações indevidas e o julgamento antecipadíssimo da lide. In: CALDERIA, Adriano. Terceira etapa da reforma do código de processo civil: estudos em homenagem ao ministro José Augusto Delgado. Salvador: JusPodivm, 2007. p. 174.

${ }^{336}$ CAMBI, Eduardo. Julgamento prima facie (imediato) pela técnica do art. 285-A do CPC. Disponível em $<$ www.abdpc.org.br/artigos/artigo1033.doc>. Acesso em: 09 jun. 2011. No mesmo sentido: FREIRE JÚNIOR, Américo Bedê. A proibição de "reformatio in peju" e o novo art. 285-A. Jus Navigandi, Teresina, ano 10, n. 1091, 27 jun. 2006. Disponível em: $<$ http://jus2.uol.com.br/doutrina/texto.asp?id=8565>. Acesso em: 13 maio 2010. A respeito do tema, confira-se, ainda, julgado que segue: "APELAÇÃO CÍlVEL. AÇÃO ORDINÁRIA DE COBRANÇA. CADERNETA DE POUPANÇA. CORREÇÃO MONETÁRIA. PRESCRIÇÃO VINTENÁRIA. ART. 177 CCII6 E ART. 2.028 DO NOVO CÓDIGO CIVIL. CRITÉRIO DE REMUNERAÇÃO. CONSTITUI DIREITO ADQUIRIDO DOS POUPADORES, CONFORME DISPÕE O ART. $5^{\circ}$, XXXVI DA CF, A
} 


\subsection{Da formação da coisa julgada}

Outro ponto que merece ser analisado diz respeito à possibilidade de a sentença proferida nos moldes do art. 285-A do CPC fazer coisa julgada, isto é, tornar-se indiscutível dentro e fora do processo em que foi proferida, bem como qual seu limite subjetivo.

A noção de coisa julgada, garantia individual de natureza constitucional (art. 5o., inc. XXXVI, da CF), estabelece que a decisão judicial que enfrente um litígio tenda a ser imodificável, não podendo mais ser impugnada. Sob este rótulo (coisa julgada), todavia, separam-se duas modalidades - a coisa julgada formal e a coisa julgada material.

O Código de Processo Civil não define a coisa julgada formal, que apenas está descrita na Lei de Introdução ao Código Civil: "Chama-se coisa julgada ou caso julgado a decisão judicial de que já não caiba recurso" (art. $6^{\circ}, \S 3^{\circ}$.). Diz-se, assim, que a coisa julgada formal surge quando a decisão não possa mais, naquele mesmo feito no qual foi proferida, ser rediscutida, por esgotadas as vias recursais.

A coisa julgada formal corresponde à hipótese de imutabilidade da sentença dentro do processo em que foi proferida por não mais se sujeitar à apresentação de qualquer recurso (ordinário ou extraordinário) da parte. Assim, exaurida a possibilidade recursal (seja pelo esgotamento dos recursos, pela ausência de interposição de qualquer recurso no prazo legal ou, ainda, pela interposição sem a observância dos requisitos necessários para tanto), a sentença transita formalmente em julgado, tornado-se imutável. ${ }^{337}$

A coisa julgada material, por sua vez, contém dispositivo expresso no artigo 467, do Código de Processo Civil e exige como requisito indeclinável a formação de coisa

INCIDÊNCIA DO REGRAMENTO VIGENTE À ÉPOCA DO ANIVERSÁRIO DA CONTA-POUPANÇA, ASSIM CONSIDERADA A DATA DE DEPÓSITO. PLANOS BRESSER, VERÃO E COLLOR. (...) II. HONORÁRIOS ADVOCATÍCIOS. JULGAMENTO COM ARRIMO NO ART. 285-A DO CPC. FORMACÃO DO CONTADITÓRIO. NECESSIDADE DE FIXACÃO. Quando a sentença julga o processo com arrimo no permissivo do art. 285-A do CPC, descabida a fixação de honorários advocatícios, por ausência de citação do réu. Todavia, interposta apelação pelo autor, com a conseqüente citação do réu, que apresenta contra-razões, impositiva a fixação de honorários ao vencido, na forma do art. 20 do CPC. APELAÇÃO DESPROVIDA. CONDENAÇÃO DA AUTORA, PORÉM, NOS ÔNUS DA SUCUMBÊNCIA, PORQUANTO INSTAURADO O CONTRADITÓRIO COM A APRESENTAÇÃO DE CONTRA-RAZÕES PELO DEMANDADO”. (Apelação Cível No 70021059472, Primeira Câmara Especial Cível, Tribunal de Justiça do RS, Relator: Miguel Ângelo da Silva, Julgado em 27/02/2008) - grifos nossos.

${ }^{337}$ TESHEINER, José Maria. Eficácia da sentença e coisa julgada no processo civil. São Paulo: Ed. Revista dos Tribunais, 2001. p. 72-73. 
julgada formal. Contudo, adiciona qualidade mais ampla: a imutabilidade do decidido vale não apenas para a mesma relação processual, mas também em qualquer outro feito.

A coisa julgada material refere-se, nas precisas palavras de Ovídio Baptista da Silva, à "estabilidade que torna a sentença indiscutível entre as partes, impedindo que os juízes dos processos futuros novamente se pronunciem sobre aquilo que fora decidido". 338

Para melhor compreender essas duas modalidades, cabe lembrar que as sentenças podem analisar o mérito da causa ou não (arts. 267 e 269). Se o processo é extinto sem resolução do mérito, a decisão está apta apenas a formar a coisa julgada formal: a parte pode reiterar a ação, tencionando novamente debater o mesmo litígio. A decisão de mérito, todavia, uma vez tornada irrecorrível, ou seja, formada a coisa julgada formal, impede que também seja reapreciada em outro feito.

Há de se distinguir, ainda, os limites objetivos e subjetivos da coisa julgada. No primeiro caso, a coisa julgada não abrange a sentença como um todo, não se incluindo nela: os motivos, a verdade dos fatos e a apreciação da questão prejudicial, decidida incidentalmente no processo (art. 469, do Código de Processo Civil). O que faz coisa julgada material é o dispositivo da sentença, a sua conclusão.

Os limites subjetivos, por sua vez, dizem respeito às pessoas atingidas pela coisa julgada material. Neste sentido tem-se que a coisa julgada pode operar-se inter partes, quando se vinculam somente às partes do processo (é a regra geral, consagrada no art. 472, CPC), ultra partes, se ela atinge não só as partes do processo como também certos terceiros como, por exemplo, em casos de substituição processual ou erga omnes, quando atinge a todos, tenham ou não participado do processo, como ocorre nas ações coletivas sobre direitos difusos ou individuais homogêneos e ações de controle concentrado de constitucionalidade. ${ }^{339}$

Fixadas essas premissas, temos para nós que a sentença de improcedência proferida com aplicação do art. 285-A é apta a produzir coisa julgada formal e material, isto é, tornar-se imutável e indiscutível.

\footnotetext{
${ }^{338}$ SILVA, Ovídio A. Baptista da. Curso de processo civil: processo de conhecimento, cit., v. 1, p. 457.

${ }^{339}$ Fredie Didier Jr., Paula Sarno Braga e Rafael Oliveira bem explicam a questão. (DIDIER JÚNIOR, Fredie; BRAGA, Paula Sarno; OLIVEIRA, Rafael. Curso de direito processual civil: teoria geral da prova, direito probatório, teoria do precedente, decisão judicial, coisa julgada e antecipação dos efeitos da tutela. 7 . ed. Salvador: Ed. Jus Podivm, 2012. v. 2, p. 428-432).
} 
Com efeito, a sentença de improcedência prima facie apresenta todos os requisitos necessários à formação da coisa julgada material. O primeiro deles refere-se à existência de decisão jurisdicional. O segundo requisito para a coisa julgada material é a existência de decisões de mérito. Necessário, ainda, tratar-se de decisão fundada em cognição exauriente, isto é, necessária cognição exaustiva para que a indiscutibilidade se justifique ${ }^{340}$. Por fim, só haverá coisa julgada material se a decisão já estiver preclusa no processo, se não se puder discutir a decisão no processo em que foi proferida. ${ }^{341}$

No mesmo sentido, Frederico Augusto Leopoldino Koehler assevera que não há como negar que a sentença liminar de improcedência ocasionará, após o trânsito em julgado, a formação da coisa julgada material, à medida que o mérito da lide foi devidamente apreciado e decidido. ${ }^{342}$

Indo adiante, no que diz respeito à investigação dos limites subjetivos da coisa julgada, isto é, apuração de quem será beneficiado ou prejudicado pela sentença, tem-se que, em princípio, os efeitos da sentença de improcedência prima facie só são imutáveis para as partes ${ }^{343}$.

\footnotetext{
${ }^{340}$ Nesse sentido: "Ao aplicar o artigo 285-A, o juiz rejeita o pedido predominantemente jurídico fundado em causa de pedir idêntica à de outra demanda já processada no juízo. Sua cognição não será sumária, mas exauriente, máxime porque seu entendimento, como já visto, estará baseado em súmula ou posição manifestamente dominante dos tribunais superiores". (SILVA, Ricardo Alexandre da. Anotações sobre o artigo 285-A do Código de Processo Civil. In: ABREU, Pedro Manoel; OLIVEIRA, Pedro Miranda de (Coords.). Direito e processo: estudos em homenagem ao desembargador Norberto Ungaretti. Florianópolis: Conceito, 2007. p. 823). Destaque-se, no mesmo sentido, posicionamento de Rodrigo Ramina de Lucca: "Ao julgar prima facie causas repetitivas, o juiz conhece profundamente as questões unicamente de direito - e, por ter convicção já formada sobre aquilo, tendo inclusive decidido de determinada maneira, julga rapidamente o processo. Tal sentença tem como alicerce uma "certeza" de que a pretensão do autor é ilegítima". (LUCCA, Rodrigo Ramina de. Resolução liminar do mérito, cit., p. 135).

${ }^{341} \mathrm{Em}$ sentido contrário, Marco Antônio Ribas Pissurno conclui que, tal espécie de sentença definitiva não passível de produzir coisa julgada formal e material, agride os imediatos interesses do autor que busca o Poder Judiciário para sanar, mediante cognição plena e exauriente, o conflito de interesses qualificado pela pretensão resistida e não para receber um pronunciamento açodado de mérito, sem que ao menos seja o réu citado. (PISSURNO, Marco Antônio Ribas. Primeiras impressões sobre o novo art. 285-a do CPC (Lei ${ }^{\circ}$ 11.277/06): alguns aspectos práticos da sentença de improcedência liminar em "processos repetitivos". Jus Navigandi, Teresina, ano 10, n. 993, 21 mar. 2006. Disponível em: <http://jus2.uol.com.br/doutrina/texto.asp?id=8128>. Acesso em: 13 maio 2010. Em sentido semelhante: "Em sintese, o julgamento aí realizado ocorre in status assertionis e inaudita altera pars, não podendo, por isso mesmo, a decisão dele resultante cristalizar-se em coisa julgada material”. (SÁ, Djanira Maria Radamés de; PIMENTA, Haroldo. Reflexões iniciais sobre o art. 285-A do Código de Processo Civil, cit., p. 144).

${ }^{342}$ KOEHLER, Frederico Augusto Leopoldino. Breve análise sobre alguns aspectos polêmicos da sentença liminar de improcedência (artigo 285-A do CPC), cit., p.75.

${ }^{343}$ José Rogério Cruz e Tucci assevera que o conceito de parte é eminentemente processual e sustenta que "Todo aquele que não atua no processo na condição de sujeito parcial (parte) é considerado terceiro. Não integrando o contraditório, não é titular dos poderes, faculdades, ônus, deveres e sujeição próprios das partes. Ora, por não terem participado dos atos que precedem e preparam o julgamento final, os terceiros não podem sofrer os efeitos da sentença de mérito e muito menos se vincularem à coisa julgada material". (CRUZ E TUCCI, José Rogério. Limites subjetivos: da eficácia da sentença e da coisa julgada civil. São Paulo: Ed. Revista dos Tribunais, 2006. p. 39).
} 
A questão, no que diz respeito ao autor e ao réu, quando citado, não enseja maiores dificuldades, já que a coisa julgada incidirá sobre ambos. Todavia, nos casos em que não haja apelação do autor e, por conseguinte, citação do réu para integrar a relação processual, este não será considerado parte e a imutabilidade da decisão o vinculará tão somente por lhe propiciar benefícios.

Reiteramos, aqui, a necessidade de intimação do réu sobre o resultado do processo, nos casos em que não houver interposição de apelação para que, ciente, possa se valer desta sentença transitada em julgado (coisa julgada material) na hipótese do autor intentar nova ação como os mesmos fundamentos. 


\title{
CAPítulo IV. ANÁlise DA CONSTITUCIONALIDADE DO ARTIGO 285-A DO CÓDIGO DE PROCESSO CIVIL
}

A constitucionalidade dessa norma processual é questionada pelo Conselho Federal da Ordem dos Advogados do Brasil (CFOAB), na ADIn 3.695/DF proposta perante o Supremo Tribunal Federal, em que se discutem cinco vícios que, de acordo com o professor Fernando da Fonseca Gajardoni, afrontariam os seguintes princípios constitucionais:

\begin{abstract}
1) a isonomia constitucional, pois os entendimentos diversos dos vários juízos acarretarão processos com curso normal e outros com curso abreviado (para as varas onde já tenha entendimento consolidado pela improcedência do pedido); 2) a segurança jurídica, porque a repetição da sentença dada em outro caso - da qual terceiros não têm ciência dos argumentos e da analogia com o caso que é apresentado - torna ilegítima a atuação jurisdicional; 3) o direito de ação, preterido pelo súbito bloqueio da regular formação da relação jurídica processual; 4) o contraditório, já que o requerido não poderá debater e convencer o juízo do acerto de sua tese; e 5) o devido processo legal, visto como o feixe de direitos e garantias condutoras do processo de seu começo ao fim. ${ }^{344}$ grifos nossos.
\end{abstract}

Além da Ordem dos Advogados do Brasil, existem alguns doutrinadores que também emitem posicionamento contrário à aplicação, no ordenamento jurídico brasileiro, do julgamento prima facie nos casos de demandas repetitivas por meio do art. 285-A. Dentre as posições contrárias à constitucionalidade do dispositivo, destaca-se, por exemplo, a de Paulo Roberto de Gouvêa Medina que afirma:

Nada mais incompatível com o contraditório do que a possibilidade de o
litígio resolver-se por meio de sentença transladada de outro processo, em
que o autor não interveio. Porque, dessa forma, a lide estará sendo
composta sem que a parte prejudicada tenha podido discutir, previamente,
os elementos que influíram na motivação da sentença. Esta, no caso, terá
sido para o autor (e também para parte contrária em relação à qual o
pedido fora formulado) "res inter alios acta". 345

\footnotetext{
${ }^{344}$ GAJARDONI, Fernando da Fonseca. O princípio constitucional da tutela jurisdicional sem dilações indevidas e o julgamento antecipadíssimo da lide, cit., p. 157.

${ }^{345}$ MEDINA, Paulo Roberto de Gouvêa. Sentença emprestada: uma nova figura processual. Revista de Processo, São Paulo, n. 135, 2006. p. 156.
} 
Paulo Restiffe, em posição análoga, argumenta que a ausência de citação e, por conseguinte, ausência da triangularização processual, bem como a permissão dada ao juiz para prolatar sentença tendo por fundamento julgado proferido em outra demanda, restringem o devido processo legal e elimina o contraditório em primeiro grau. ${ }^{346}$

Desse entendimento também comungam Djanira Maria Radamés e Haroldo Pimenta que advertem que o disposto no art. 285-A do CPC brasileiro "equivale a decisão in limine que, de modo algum é inerente ao devido processo legal e, assim, conspira a um só tempo contra essa garantia e contra um de seus consectários, o princípio do contraditório e da ampla defesa". 347

Para a incidência do art. 285-A do CPC, faz-se necessária prévia e ampla discussão sobre a "tese jurídica", inclusive com a participação de amicus curiae, sob pena de afronta aos princípios do devido processo legal e acesso à justiça, uma vez que "a possibilidade de debate a posteriori da questão é apequenada não só pelo que é possível extrair da letra do art. 285-A mas também porque a apelação interposta da sentença que o aplicar nem sequer terá revisão (art. 515, $\$ 3^{\circ}$ )”. 348

Enquanto o Conselho Federal da Ordem dos Advogados do Brasil defende a inconstitucionalidade do dispositivo, o Instituto Brasileiro de Direito Processual - IBDP intervém como amicus curiae para defender a constitucionalidade do art. 285-A do CPC. Em sua peça, o IBDP repele os argumentos expostos pelo CFOAB, afirmando que o novel dispositivo legal "realiza adequadamente o 'modelo constitucional do processo civil brasileiro', bem combinando as eficácias dos diversos princípios regentes da atuação jurisdicional em busca de um processo civil mais justo, mais equânime, mais racional. „349

O Advogado Geral da União no desempenho de seu papel constitucional defendeu a lei questionada, pugnando pela improcedência do pedido constante da inicial. O Procurador Geral da República, de igual modo, entendeu que Lei 11.416 não configura afronta aos princípios constitucionais ventilados pelo CFOAB e sustentou, ainda, que a

\footnotetext{
${ }^{346}$ RESTIFFE, Paulo Sérgio. Reforma do CPC: modificação das regras recursais e julgamento liminar definitivo em processos repetitivos - Leis 11.276 e 11.277. Revista Dialética de Direito Processual, São Paulo, n. 37, p. 119, abr. 2006.

${ }^{347}$ SÁ, Djanira Maria Radamés de; PIMENTA, Haroldo. Reflexões iniciais sobre o art. 285-A do Código de Processo Civil, cit., p. 138.

${ }^{348}$ Cf. BUENO, Cássio Scarpinella. A nova etapa do Código de Processo Civil: comentários sistemáticos às Leis n. 11.276 de 7-2-2006, 11.277, de 7-2-2006, e 11.280, de 16-2-2006, cit., v. 2, p. 64-65.

${ }^{349}$ As peças eletrônicas da ADIn 3.695/DF podem ser consultadas através do sítio eletrônico do SUPREMO TRIBUNAL FEDERAL. Disponível em: $<$ http://redir.stf.jus.br/estfvisualizadorpub/jsp/consultarprocessoeletronico/ConsultarProcessoEletronico.jsf? seqobjetoincidente $=2373898>$.
} 
mesma está em harmonia também com o princípio da duração razoável do processo, inserido no ordenamento brasileiro pela EC 45/2004.

Parte considerável da doutrina, da mesma maneira, não vê qualquer desrespeito às normas constitucionais, defendendo exatamente o contrário, isto é, que o art. 285-A, na verdade, vai ao encontro dos princípios constitucionais. ${ }^{350}$

Ernane Fidélis dos Santos afasta a tese de inconstitucionalidade do dispositivo por entender que o contraditório e a ampla defesa estariam assegurados pela faculdade reconhecida ao autor de recorrer da sentença de improcedência, não negada pelo parágrafo $1^{\circ}$, do artigo 285-A do CPC. ${ }^{351}$

Em defesa do dispositivo legal, há quem argumente ser importante buscar compatibilizar todas as normas e princípios, uma vez que nenhum deles é absoluto, motivo pelo qual se devem buscar mecanismos que garantam “a efetiva prestação jurisdicional, seriamente comprometida pela multiplicação de demandas com a mesma tese jurídica e que poderiam ser decididas rapidamente com o desafogo evidente da Justiça”. 352

Gustavo Martins dos Santos, após exame do instituto da sentença liminar de improcedência prevista no art. 285-A do CPC, conclui ser o mesmo "compatível com a Constituição e útil ao exercício dos direitos fundamentais que permeiam o processo civil, em especial a celeridade processual, a economia processual, a razoável duração do processo e, até mesmo, o devido processo legal”. 353

Calha registrar, ainda, posicionamento no sentindo de que "não há qualquer inconstitucionalidade no art. 285-A do CPC, que, ao ponderar diversos princípios constitucionais, fixa um procedimento específico para o julgamento de demandas repetitivas, as quais se encontram fadadas à improcedência". 354

\footnotetext{
${ }^{350}$ Cf. ATAÍDE JÚNIOR, Vicente de Paula. A resolução antecipada do mérito em ações repetitivas (lei 11277/2006), cit., p. 118-119; ARAÚJO, Luciano Vianna. 285-A do CPC (julgamento imediato, antecipado e maduro da lide): evolução do sistema desde o Código de Processo Civil de 1939 até 2007, cit., p. 166.

${ }^{351}$ SANTOS, Ernane Fidélis dos. Manual de direito processual civil: processo de conhecimento. 13. ed. São Paulo: Saraiva, 2009. v. 1, p. 230-232.

${ }^{352}$ GRECO FILHO, Vicente. Direito processual civil brasileiro. 20. ed. São Paulo: Saraiva, 2009. v. 2, p. 81.

${ }^{353}$ SANTOS, Gustavo Martins dos. A sentença liminar do artigo 285-A do CPC e a celeridade processual: uma abordagem à luz dos princípios da isonomia, do acesso à justiça e do devido processo legal. Revista da Seção Judiciária do Rio de Janeiro, Rio de Janeiro, n. 26, p. 84, dez. 2009.

${ }^{354} \mathrm{Cf}$. ARAÚJO, Luciano Vianna. 285-A do CPC (julgamento imediato, antecipado e maduro da lide): evolução do sistema desde o Código de Processo Civil de 1939 até 2007, cit., p. 179.
} 
Seguindo tais entendimentos, verifica-se que a Lei 11.277 de 2006, ao instituir o art. 285-A do CPC, não contradiz nenhum princípio, estando em sintonia com as mais hodiernas necessidades processuais.

Até o momento em que se redige este trabalho, a ADIn pende de exame meritório, sendo que a última movimentação no feito refere-se à publicação, em Setembro de 2012, da ata de decisão que dá conta de sua retirada de pauta para julgamento ante a aposentadoria do Ministro relator Cezar Peluso. As manifestações constantes da ação direta de inconstitucionalidade sinalizam para sua improcedência, ou seja, para a declaração de constitucionalidade da Lei $\mathrm{n}^{\mathrm{o}}$ 11.277/2006. Entendemos, contudo, que se o Supremo Tribunal Federal optar por declarar a inconstitucionalidade do dispositivo, sem flexibilizar os efeitos de sua decisão, teremos sérios problemas.

Passaremos, adiante, a uma análise mais detalhada da compatibilidade do dispositivo em comento com os diversos princípios constitucionais, a fim de verificar se se sustentam os supostos vícios que fundamentam a ADIn 3.695/DF, apresentando ao final de cada tópico nossas conclusões a respeito do tema.

\subsection{Princípio da isonomia}

Inicialmente, para que se possa compreender a verdadeira ideia do Princípio da Igualdade, importa fazer uma análise de sua evolução histórica, a qual pode ser dividida em três fases distintas, quais sejam: a nominalista; a idealista; e a realista.

Na primeira fase, conhecida como nominalista, entendia-se que a desigualdade era um atributo do próprio universo, sendo que as pessoas nasceriam desiguais e assim permaneceriam até sua morte. Essa concepção foi utilizada pela sociedade dominante da época para construir um sistema que só fazia privilegiar aqueles que detinham poder e riqueza. Nesse período, "prevaleceram, então, as timocracias, os regimes despóticos, asseguraram-se os privilégios e sedimentaram-se as diferenças, especificadas em leis. As revelações de igualdade eram parcas e as leis não as revelavam, nem resolviam as desigualdades". 355

\footnotetext{
${ }^{355}$ Cf. ROCHA, Cármen Lúcia Antunes. O princípio constitucional da igualdade. Belo Horizonte: Ed. Lê, 1990. p. 36.
} 
Num segundo momento histórico, na chamada fase idealista, sustentava-se que a igualdade é da essência dos homens, o que implicava o dever do legislador elaborar normas gerais e abstratas, esvaziadas de privilégios, bem como fosse a norma aplicada de modo uniforme a toda sociedade. ${ }^{356}$

Com o passar do tempo, contudo, constatou-se que essa igualdade (igualdade formal) era insuficiente para criar uma isonomia efetiva, real, subsistindo, portanto, a desigualdade entre as classes.

Surge, assim, um terceiro momento, denominado como realista, que apesar de reconhecer a igualdade como qualidade ínsita a todo homem, entende existirem desigualdades diversas, de ordem social, política e econômica que obstam a obtenção da isonomia de fato. ${ }^{357}$

A Revolução Francesa de 1789, cujo lema era "Liberdade, Igualdade e Fraternidade", marcou o fim do sistema absolutista e dos privilégios da nobreza naquele país e, além de determinar os fundamentos do que hoje compreendemos por justiça e democracia, foi de fundamental relevância para consolidação dos direitos humanos dentro do cenário internacional e para busca de ideais de isonomia. ${ }^{358}$

A Declaração Universal dos Direitos Humanos da Organização das Nações Unidas de 1948, por sua vez, afirma em seu artigo primeiro que: “Todas as pessoas nascem livres e iguais em dignidade e direitos. São dotadas de razão e consciência e devem agir em relação umas às outras com espírito de fraternidade”. 359

No Brasil, a primeira constituição a mencionar o Princípio da Igualdade foi a Constituição Republicana de 24 de fevereiro de 1891, que dispôs na seção destinada à declaração de direito, em seu art. 72, § $2^{\circ}$ “Todos são iguais perante a lei. A República não admite privilégios de nascimento, desconhece foros de nobreza e extingue as ordens

\footnotetext{
${ }^{356}$ Cf. SARMENTO, Daniel. Livres e iguais: estudos de direito constitucional. Rio de Janeiro: Lumen Juris Ed., 2006. p. 143-147.

${ }^{357}$ Cf. BRUNINI, Gabriela Zancaner. Considerações sobre o princípio da isonomia. Revista Trimestral de Direito Público, São Paulo, n. 46, p. 214, 2004.

${ }^{358} \mathrm{~A}$ corroborar o que acabamos de anotar, confira-se: "Como os ideais de liberdade, igualdade $e$ fraternidade são sedutores a todos os seres humanos, os Estados perceberam a necessidade de efetivar tais idéias e iniciou-se um movimento no sentido de inserir na lei de maior importância dos países esses pensamentos; posteriormente denominado constitucionalização do Direito”. (OLIVEIRA NETO, Olavo de.; OLIVEIRA, Patrícia Elias Cozzolino de. Princípio da isonomia. In: OLIVEIRA NETO, Olavo de; LOPES, Maria Elizabeth de Castro (Orgs.). Princípios processuais civis na Constituição. Rio de Janeiro: Elsevier Campus, 2008. p. 139).

${ }^{359}$ DECLARAÇÃO UNIVERSAL DOS DIREITOS HUMANOS. Adotada e proclamada pela resolução 217 A (III) da Assembléia Geral das Nações Unidas em 10 de dezembro de 1948. Disponível em: <http://portal.mj.gov.br/sedh/ct/legis_intern/ddh_bib_inter_universal.htm>. Acesso em: 27 out. 2012.
} 
honorificas existentes e todas as suas prerrogativas e regalias, bem como os títulos nobiliárquicos e de conselho".

O princípio já começava a ganhar novos contornos, tanto é assim que Rui Barbosa, baseando-se na lição Aristotélica, ao discursar para os formandos em Direito da Universidade Federal de São Paulo em 1920, apregoou que "a regra da igualdade não consiste senão em quinhoar desigualmente os desiguais, na medida em que se desigualam., 360

Presente também em outros textos constitucionais, como por exemplo na Constituição Popular de 1934, Constituição de 1937 e na Constituição de 1967, importante salientar que a Constituição Federal de 1988, ao lado de outros princípios constitucionais, também contemplou o princípio da Igualdade. Contudo, diferentemente das Constituições que lhe antecederam, expressou preocupação não só com seu sentido formal, como também com o seu sentido material. ${ }^{361}$

Antes de continuarmos, faz-se necessário conceituar o que vem a ser esse princípio tão almejado pela sociedade e cuja presença se faz sentir em tantos textos normativos. Cármen Lúcia Antunes Rocha, sobre o conceito do princípio da igualdade, assim se manifesta:

\begin{abstract}
"O princípio jurídico da igualdade é o que a sociedade quer que ele seja. Não é obra de Deuses, nem formas heterônomas, nem de forças exógenas que se impõem a uma sociedade com explicações místicas e mistificadas. O ser humano iguala-se a outro quanto à sua natureza e à sua essência e desiguala-se em sua contingência humana e em sua continência social. $O$ Direito é o que a sociedade - ou, muita vez, o eventual detentor da capacidade de ditar normas diz que ele é". ${ }^{362}$
\end{abstract}

\footnotetext{
${ }^{360}$ BARBOSA, RUI. Oração aos moços. 5.ed. Edição popular anotada por Adriano de Gama Cury. Rio de Janeiro: Edições Casa de Rui Barbosa, 1999. p. 25. Disponível em: <http://www.casaruibarbosa.gov.br/dados/DOC/artigos/rui_barbosa/FCRB_RuiBarbosa_Oracao_aos_moco s.pdf>. Acesso em: 28 out. 2012.

${ }^{361}$ Nessa toada, não é demais concluir que: "a Constituição Federal de 1988 busca a aproximação dos dois tipos de isonomia, uma vez que não se limita à mera enunciação da igualdade perante a lei, trazendo, também, disposições que enunciam preceitos de igualdade material, como as relativas à proibição de discriminações de qualquer natureza (artigo $3^{\circ}, I V$ ). A igualdade assegurada no texto constitucional é o valor supremo que irá permitir a busca pela construção de uma sociedade livre, justa e solidária (artigo $3^{o}$, I)”. SILVA, Júlia Lenzi; PEREIRA NETTO, Juliana Presotto. Digressões acerca do princípio da igualdade enquanto pressuposto de existência do devido processo legal e a questão afeta ao exercício do jus postulandi nos juizados especiais federais. Revista da Faculdade de Direito do Sul de Minas (eletrônica), Pouso Alegre, v. 27 n. 1, p. 217-242, jan./jun. 2011 Disponível em: $<$ http://www.fdsm.edu.br/Revista/Volume27_1/Vol271_10.pdf>. Acesso em: 24 set. 2012.

${ }^{362} \mathrm{Cf}$. ROCHA, Cármen Lúcia Antunes. O princípio constitucional da igualdade, cit., p. 28.
} 
Fernanda Tartuce defende ser possível fazer alusão à isonomia tanto como princípio, direito fundamental ou garantia sem que exista qualquer tipo de embaraço. Isto porque, explica a autora, "a isonomia apresenta um aspecto político relevante e sua adoção exige o comprometimento dos agentes políticos para a efetiva concretização da proposta isonômica”. No mais, assevera que não é verdadeiro "qualquer discurso sobre sua possível limitação pelo legislador porque configuraria princípio e não garantia”. Por fim, conclui: “dada a multiplicidade de contemplações no Estado de Direito, é essencial que haja esforços para sua implementação a despeito da dificuldade experimentada para tanto". 363

Sob seu duplo aspecto, de acordo com Paulo Luiz Netto Lôbo, a igualdade formal tem por intento afastar qualquer diferença entre os indivíduos, sendo que "seu escopo é a esfera normativa que não se pode tornar fonte de privilégios, impondo para tanto tratamento uniforme perante a lei e vedando tratamento desigual a todos que são considerados como iguais". A igualdade, sob o seu aspecto substancial, ressalta o autor, "é aquela que assegura o tratamento uniforme de todos os homens, resultando em igualdade real e efetiva de todos, perante todos os bens da vida". ${ }^{364}$

Verifica-se, assim, que nossa Constituição Federal, ao longo de todo o seu texto normativo, evidencia clara preocupação com o Princípio da Igualdade, tanto em seu aspecto formal quanto em seu aspecto material. ${ }^{365}$

De início, fez constar de seu Preâmbulo a previsão de um Estado Democrático destinado a assegurar a igualdade e a justiça como valores de nossa sociedade. Indo adiante, no caput de seu artigo $5^{\circ}$ consagrou a ideia de que a lei deve ser indistintamente aplicada a todas as pessoas (igualdade, aqui, no sentido formal).

\footnotetext{
${ }^{363}$ TARTUCE, Fernanda. Igualdade e vulnerabilibidade no processo civil. Rio de Janeiro: Forense, 2012. p. 60.

${ }^{364}$ LÔBO, Paulo Luiz Netto. Igualdade. In: TORRES, Ricardo Lobo; KATAOBA, Eduardo Takemi; GALDINO, Flavio (Org.). Dicionário de princípios jurídicos. Rio de Janeiro: Elsevier, 2011. p. 526.

${ }^{365}$ Nesse sentido, destaca Alexandre de Moraes que: “A Constituição Federal de 1988 adotou o princípio da igualdade de direitos, prevendo a igualdade de aptidão, uma igualdade de possibilidades virtuais, ou seja, todos os cidadãos têm o direito de tratamento idêntico pela lei, em consonância com os critérios albergados pelo ordenamento jurídico. Dessa forma, o que se veda são as diferenciações arbitrárias, as discriminações absurdas, pois, o tratamento desigual dos casos desiguais, na medida em que se desigualam, é exigência tradicional do próprio conceito de justiça, pois o que realmente protege são certas finalidades, somente se tendo por lesado o princípio constitucional quando o elemento discriminador não se encontra a serviço de uma finalidade acolhida pelo direito, sem que se esqueça, porém, como ressalvado por Fábio Konder Comparato, que as chamadas liberdades materiais têm por objetivo a igualdade de condições sociais, meta a ser alcançada, não só por meio de leis, mas também pela aplicação de políticas ou programas de ação estatal”. (MORAES, Alexandre de. Direito constitucional. 21. ed. São Paulo: Atlas, 2007. p. 31).
} 
Contudo, não parou aí. A fim de garantir efetividade a este princípio, espalhou por todo o texto constitucional sementes do desejável fruto da igualdade, como se observa dos $\operatorname{artigos} 3^{\circ}$, incisos I e XXXII do artigo $5^{\circ}$, o inciso XXXI, do artigo $7^{\circ}$ e outros (em todos esses, igualdade em sentido substancial).

Além desse duplo aspecto da igualdade: a igualdade formal e a igualdade material, José Souto Maior Borges aponta a existência de outra importante distinção no tratamento da igualdade jurídica, quais sejam: a “igualdade perante a lei e igualdade na lei”. Aduz, ainda, que para o aperfeiçoamento do direito à isonomia mister se faz a presença desses dois conteúdos, bem como de meios assecuratórios desse direito. ${ }^{366}$

Não é demais ressaltar que o aspecto material do princípio constitucional em comento determina além da não discriminação perante a lei, uma atitude pró-ativa por parte do Estado no sentido de dar oportunidades, atentando-se para as peculiaridades daqueles menos favorecidos ou marginalizados. ${ }^{367}$

Quanto aos destinatários do princípio ora analisado, temos para nós que o mesmo serve de baliza para a conduta do legislador ou do próprio executivo, que no momento de elaboração qualquer tipo de norma deve fixar diferenciações abusivas; da autoridade

\footnotetext{
${ }^{366}$ No tocante à primeira, igualdade diante da lei, entende o autor que esta "somente postula que a aplicação da lei corresponda sempre à sua incidência, Daí o seu caráter formal: nada prescreve sobre a igualdade como o conteúdo da própria lei aplicada. A tônica é aí na inexceptualidade da aplicação concreta da norma, sempre que ocorrentes os seus pressupostos fácticos". Já com relação à segunda, igualdade na lei, entende que esta corresponde à igualdade material. Ressalta que esta "somente existe quando a lei prescreve um tratamento igualitário. Será a igualdade, em tais condições, "matéria" do ato legislativo". (BORGES, José Souto Maior. Significação do princípio da isonomia na Constituição de 1988. Revista Trimestral de Direito Público, São Paulo, n. 15, p. 31-33, 1996). Ideia semelhante já havia sido ventilada pelo Ministro Celso de Mello, conforme se verifica da ementa que segue: "O princípio da isonomia, que se reveste de auto-aplicabilidade, não é - enquanto postulado fundamental de nossa ordem político-jurídica suscetível de regulamentação ou de complementação normativa. Esse princípio - cuja observância vincula, incondicionalmente, todas as manifestações do Poder Público - deve ser considerado, em sua precípua função de obstar discriminações e de extinguir privilégios (RDA 55/114), sob duplo aspecto: (a) o da igualdade na lei; e (b) o da igualdade perante a lei. A igualdade na lei - que opera numa fase de generalidade puramente abstrata - constitui exigência destinada ao legislador que, no processo de sua formação, nela não poderá incluir fatores de discriminação, responsáveis pela ruptura da ordem isonômica. A igualdade perante a lei, contudo, pressupondo lei já elaborada, traduz imposição destinada aos demais poderes estatais, que, na aplicação da norma legal, não poderão subordiná-la a critérios que ensejem tratamento seletivo ou discriminatório. A eventual inobservância desse postulado pelo legislador imporá ao ato estatal por ele elaborado e produzido a eiva de inconstitucionalidade." (MI 58, Rel. p/ o ac. Min. Celso de Mello, julgamento em 14-12-1990, Plenário, DJ de 19-4-1991).

${ }^{367}$ Nesse sentido: "A absoluta igualdade jurídica não pode, contudo, eliminar a desigualdade econômica; por isso, do primitivo conceito de igualdade, formal e negativa (a lei não deve estabelecer qualquer diferença entre os indivíduos), clamou-se pela passagem à igualdade substancial. E hoje, na conceituação positiva da isonomia (iguais oportunidade para todos, a serem propiciadas pelo Estado), realça-se o conceito realista, que pugna pela igualdade proporcional, a qual significa em síntese, tratamento igual aos substancialmente iguais". (CINTRA, Antônio Carlos de Araújo; DINAMARCO, Cândido Rangel; GRINOVER, Ada Pellegrini. Teoria geral do processo, cit., p. 59-60).
} 
estatal, no momento de aplicar a lei ao caso concreto, bem como de todos os cidadãos, que deverão evitar condutas discriminatórias.

Do exposto, temos que não implica ofensa ao princípio da igualdade o tratamento diferenciado que pode ser dispensado a algumas pessoas que estejam nas mesmas condições de fato, desde que a distinção guarde congruência substancial com o princípio. $^{368}$

Nesse ponto, questão que surge refere-se em como distinguir quando um tratamento diferenciado é permitido e quando o critério adotado fere o princípio da isonomia, atingindo, por conseguinte, o ordenamento constitucional. O jurista Celso Antonio Bandeira de Mello defende a análise de três passos para a investigação da harmonização entre a distinção concretizada e a determinação contida no princípio da isonomia. Em primeiro lugar, prevê a análise do objeto escolhido como fator de discriminação. Num segundo momento, imperioso verificar a ocorrência de um liame lógico entre o fator colocado como critério de discriminação e a desigualdade estabelecida no tratamento jurídico diversificado. Finalmente, salienta o autor a necessidade de se verificar a conformidade entre essa correlação lógica e a preocupação com os valores do sistema constitucional em exame. O emprego desses três critérios, sustenta o autor, constitui mecanismo hábil para se concluir pela existência ou não de ofensa ao princípio da isonomia. $^{369}$

Avaliando cada um dos critérios articulados por Celso Antônio Bandeira de Mello, temos que para constatação de violação ou não ao princípio da isonomia deve-se, inicialmente, atentar para o fator de discriminação erigido pela lei, que não pode incidir sobre uma única ou determinada situação, nem tampouco pode ser alheio à esfera pessoal. Indo adiante, necessário verificar se a norma de fato precisa daquele aspecto discriminador para atingir seu escopo, isto é, se há relação entre o objeto alçado e a finalidade da norma. Por fim, impende analisar se há harmonia com os valores constitucionais do sistema.

Nesse ponto, tendo em vista que o princípio da isonomia pode ser apontado como um dos pilares do sistema jurídico convém tecer alguns comentários acerca da sua aplicação no âmbito processual, como mecanismo destinado a reequilibrar as partes. Com

\footnotetext{
${ }^{368}$ ADI 2.716, Rel. Min. Eros Grau, julgamento em 29-11-2007, Plenário, DJE de 7-3-2008.

${ }^{369}$ MELLO, Celso Antônio Bandeira de. O conteúdo jurídico do princípio da igualdade. 3. ed. São Paulo: Malheiros Ed., 1995. p. 27-28.
} 
efeito, no Código de Processo Civil, sobejam alusões à isonomia como postulado informador dos demais direitos. ${ }^{370}$

No que tange à finalidade da isonomia no âmbito processual, destacamos posição de Daniel Amorim Assumpção Neves, para o qual a mesma visa "permitir que concretamente as partes atuem no processo, dentro do limite do possível, no mesmo patamar". Para que isso seja possível, sustenta o autor que "alguns sujeitos, seja pela qualidade, seja pela natureza do direito que discutem em juízo, tem algumas prerrogativas que diferenciam seu tratamento processual dos demais sujeitos, como forma de equilibrar a disputa processual”. ${ }^{371}$

A despeito de algumas críticas, sobre as quais nos absteremos de aprofundar, diversos artigos regentes da disciplina processual trazem em seu bojo menção a aspectos diferenciadores, tidos como mecanismos para trazer a almejada igualdade processual. Senão vejamos.

Pode-se dizer que é do princípio da igualdade que deriva o princípio da igualdade das partes no processo. Por meio de tal postulado impõe-se ao juiz que defira idênticas oportunidades a todos os litigantes - tal qual explicita o art. 125, I, do CPC.

Em virtude de tal princípio, entende-se que não poderá ser concedida forma alguma de proteção a alguém por fatores meramente subjetivos, mediante a concessão de vantagem processual por predileções circunstanciais do juiz. ${ }^{372}$

A doutrina nacional vem preconizando uma maior atuação do juiz no tocante à instrução probatória, em detrimento da clássica orientação decorrente do princípio dispositivo. Defende-se que a participação ativa do magistrado na atividade probatória não o torna parcial nem viola o princípio da isonomia; ao contrário, essa participação ativa na produção das provas constitui instrumento basilar para que ocasionais desigualdades sociais, técnicas e econômicas possam ser aplacadas no processo.

Em que pese existam diversos preceitos que tratem de fixar prazos diferenciados

\footnotetext{
${ }^{370}$ Nesse tocante, destaca Fernanda Tartuce que "o processo, enquanto instrumento ético, não mais se pauta por indiferença ou neutralidade quanto aos seus fins, devendo ser regulamentado segundo as concepções filosóficas, políticas e culturais atuais de forma comprometida com a concretização da isonomia”. (TARTUCE, Fernanda. Igualdade e vulnerabilibidade no processo civil, cit., p. 135).

${ }^{371}$ NEVES, Daniel Amorim Assumpção. Manual de direito processual civil, cit., p. 554.

${ }^{372}$ A esse propósito, Rodolfo de Camargo Mancuso aponta que a "dificuldade de converter, in concreto, o valor enunciado na norma nada mais é do que a repercussão, no âmbito do processo, de análoga dificuldade para implementar, na prática, a igualdade 'assegurada' no art. 5', caput e I, CF/88”. (MANCUSO, Rodolfo de Camargo. A resolução dos conflitos e a função judicial no contemporâneo Estado de direito (nota introdutória). Revista dos Tribunais, São Paulo, v. 98, n. 888, p.9, out. 2009).
} 
para a Fazenda Pública e para o Ministério Público, um dos dispositivos mais polêmicos do Código de Processo Civil acerca do tema é o art. 188, que estabelece prazo em dobro para recorrer e em quádruplo para contestar. A doutrina divide opiniões a respeito da constitucionalidade do referido dispositivo, havendo aqueles que defendem que tal privilégio não mais se sustenta. ${ }^{373}$ Filiamo-nos, contudo, àqueles que entendem que tal benefício evidencia-se como uma prerrogativa própria desses entes, justificada pelo seu papel e pelo interesse público que esses entes representam.

Com escopo semelhante à situação anterior, a regra constante do art. 191, do CPC, concede aos litisconsortes, com procuradores diferentes, prazo em dobro para contestar, recorrer e falar nos autos. O preceito, a princípio, não promove maiores dificuldades, devendo ser aplicado quando houver pluralidade de réus ou autores, ou ambos, mas desde que defendidos por procuradores diferentes, visando uma melhor distribuição do tempo para que os procuradores das partes pudessem examinar os autos e elaborar sua resposta. Destaque-se, porém, que o prazo será tão somente dobrado, não importando quantos sejam os advogados constituídos nos autos.

Ao contrário do entendimento firmado para o art. 188 do CPC, entendemos que se a distinção prevista no art. 191 era justificável quando da edição do código em 1973, não há, nos dias atuais, argumentos suficientes para sua manutenção em nosso ordenamento, haja vista o avanço provocado pela informática e o caminho, ao que tudo indica sem volta, para o processo eletrônico.

Outro dispositivo que merece menção é o art. 100, inciso I, do CPC, que estabelece que o foro da residência da mulher seja o competente para a propositura da ação de separação judicial, divórcio e de anulação de casamento; excepcionando, assim, a regra geral de que o foro competente seria o do domicílio do réu.

Há quem defenda que o objeto de discriminação ali mencionado "não está em consonância com os arts. $5^{\circ}$, I, e 226, $\S 5^{\circ}$, da Constituição Federal; razão pela qual se verifica desrespeito ao princípio da isonomia, sendo inconstitucional o referido preceito". ${ }^{374}$ Todavia, mesmo cientes de todo o progresso e do papel da mulher no contexto histórico atual, temos para nós que ainda existem situações de evidente desvantagem entre homens e mulheres que justificam a permanência do dispositivo em comento.

\footnotetext{
${ }^{373}$ Por todos, DINAMARCO, Cândido Rangel. Instituições de direito processual civil. 6. ed. São Paulo: Malheiros Ed., 2009. v. 1, p. 216-217.

${ }^{374}$ OLIVEIRA NETO, Olavo de; OLIVEIRA, Patrícia Elias Cozzolino de. Princípio da isonomia, cit., p. 145.
} 
Como não é objetivo do presente trabalho esgotar todas as hipóteses em que o princípio isonômico adentra no mundo do processo destacamos, antes de tecermos considerações sobre a leitura adequada que se exige do art. 285-A do CPC, a prioridade no trâmite dos processos judiciais dada aos idosos.

No dia 9 de janeiro de 2001 entrou em vigor a Lei $\mathrm{n}^{\circ} 10.173$, que incluiu os artigos 1.211-A a 1.211-C no Código de Processo Civil, tendo por finalidade dar preferência ao andamento dos processos judiciais em que seja parte pessoa com idade igual ou superior a sessenta e cinco anos.

Há, nesse caso, prioridade necessária, sendo o fator discriminatório justificável, tendo em vista a posição peculiar de fragilidade própria da velhice, o que também vislumbramos nos casos de pessoas portadoras de doenças graves. ${ }^{375}$

Após este breve passeio - onde foram apresentados alguns dos aspectos mais importantes do princípio da Isonomia de forma geral e também no campo do Direito Processual Civil - passaremos a analisar se a previsão do art. 285-A do CPC viola este princípio constitucional.

Há aqueles que sustentam que esse dispositivo legal violaria o princípio da isonomia, por instituir tratamento processual distinto para situações iguais, dependendo do entendimento de cada magistrado sobre a matéria de fundo levada a exame. ${ }^{376}$

Entendemos, contudo, que não há que se falar em violação do princípio da isonomia pelo art. 285-A do CPC, uma vez que atento às peculiaridades das demandas de massa, referido artigo estimula que, a um mesmo acontecimento, seja atribuído da forma mais célere possível, mesmo resultado jurídico, conferindo aos litigantes um

\footnotetext{
${ }^{375}$ Atento a tais circunstâncias, Cândido Rangel Dinamarco ressalta que: "A tarefa de preservar a isonomia consiste, portanto, nesse tratamento formalmente desigual que substancialmente iguala. Exemplos vivos são a promessa constitucional e legal de assistência jurídica integral aos necessitados (Const., art. $5^{\circ}$, inc. LXXIV; art. 24, inc. XIII) e o tratamento especial concedido às causas de interesses de idosos, as quais devem ser processadas e julgadas com prioridade (CPC, arts. 1.211-A a 1.211-C)”. (DINAMARCO, Cândido Rangel. Instituições de direito processual civil. 6. ed., cit., v. 1, p. 213-214).

${ }^{376}$ Desse sentir, Alexandre Câmara destaca que a ofensa ao princípio da isonomia pela aplicação da regra do art. 285-A do CPC se daria sob dois aspectos. O primeiro deles diz respeito à existência de juízes com entendimentos discrepantes a respeito do mérito do pedido repetitivo. O segundo aspecto, refere-se ao tratamento processual díspar entre os respectivos jurisdicionados, mesmo encontrando-se em situação jurídica semelhantes. Nesse contexto, ilustra que aquele que tiver sua demanda distribuída ao juízo em que já tenha sido proferido julgamento de total improcedência em casos idênticos terá contra si a sentença liminar, enquanto que aqueles outros que tiverem a ação distribuída a um juízo perante o qual a questão ainda não tenha sido analisada ou sem consolidação de entendimento pela improcedência terá um processo tradicional, com citação do réu para resposta, e demais etapas que lhe são próprias. (CÂMARA, Alexandre Freitas. Lições de direito processual civil. 15. ed. Rio de Janeiro: Lumen Juris, 2006. v. 1, p. 335).
} 
tratamento igualitário. $^{377}$

Com efeito, a decisão estabelecida com base no art. 285-A não macula a igualdade, constituindo, ao contrário, verdadeira homenagem à isonomia. Isto porque, “com a reprodução da sentença precedente, estará o juiz aplicando exatamente o mesmo direito para situações idênticas”. 378

O pensamento contrário configura formalismo processual excessivo, bem como dá guarida ao dispêndio de tempo desnecessário de todos os envolvidos na relação processual e aos dispensáveis gastos com honorários, custas e taxas judiciais pelo demandado.

Se, por ventura, algum outro magistrado entender de forma diversa sobre uma mesma tese jurídica em discussão judicial e, por isso, preferir não se aplicar o preceito do art. 285-A do CPC ao caso analisado, restará aos tribunais, na ocorrência de eventual recurso, "uniformizarem, gradativamente, qual é e qual não é o entendimento prevalecente”. 379

Helena de Toledo Coelho Gonçalves defende uma suposta ofensa ao princípio da isonomia pelo art. 285-A do CPC sob o pretexto de que "fere o princípio da isonomia a administração pública ser beneficiada com sentenças liminares de improcedência quando, nas demandas procedentes, é necessário ao administrado enfrentar contenda até a última instância”. 380

Não há como prosperar tal argumento. Primeiro, porque o benefício estabelecido no artigo 285-A não é dirigido à Administração Pública. Com efeito, em que pese sejamos conhecedores do papel desse ente como “repeat player”, o art. 285-A do CPC há de ser

\footnotetext{
${ }^{377}$ Ilustrativo desse pensamento, destacamos lição de Leonardo Carneiro da Cunha: "Numa sociedade em que se exige celeridade processual, a ponto de constituir princípio constitucional o da duração razoável dos processos $\left(C F / 88\right.$, art. $5^{\circ}$, LXXVIII), é preciso que as demandas de massa tenham "soluções de massa", ou seja, recebam uma solução uniforme, garantindo-se, inclusive, o princípio da isonomia. Realmente, decorre do princípio da isonomia a necessidade de se conferir tratamento idêntico a quem se encontra em idêntica situação. Daí resulta ser imperioso envidar ingentes esforços no sentido de eliminar as divergências jurisprudenciais, pois não se deve admitir que alguém, na mesma situação de outrem, tenha solução judicial diferenciada da que lhe fora conferida. Repugna ao senso comum deparar-se com situações como essa, em que determinado sujeito não logra êxito em sua demanda judicial, quando outra pessoa, na mesma condição, teve seu pleito atendido, ainda mais quando se trata de demandas de massa, em que a situação dos interessados revela-se absolutamente idêntica”. (CUNHA, Leonardo José Carneiro da. Primeiras impressões sobre o art. 285-A do CPC (julgamento imediato de processos repetitivos: uma racionalização para as demandas de massa), cit., p. 94).

${ }^{378}$ Cf. MENEZES, Iure Pedroza. O novo art. 285-A do CPC: reflexões acerca de sua constitucionalidade. Jus Navigandi, Teresina, ano 12, n. 1479, 20 jul. 2007. Disponível em: <http://jus.com.br/revista/texto/10165>. Acesso em: 5 nov. 2012.

${ }^{379}$ BUENO, Cássio Scarpinella. A nova etapa do Código de Processo Civil: comentários sistemáticos às Leis n. 11.276 de 7-2-2006, 11.277, de 7-2-2006, e 11.280, de 16-2-2006, cit., v. 2, p. 191.

${ }^{380}$ GONÇALVES, Helena de Toledo Coelho. Contraditório e ampla defesa. Curitibva: Juruá Ed., 2010. p. 90.
} 
aplicado quando, independentemente de quem seja o réu, ou ainda, o autor, estejam presentes os requisitos determinados na norma, já esmiuçados no decorrer do presente trabalho.

Ademais, o dispositivo em comento constitui instrumento disponibilizado ao réu, como paridade de armas, à autorização contida no art. 273, II, do CPC que prevê a antecipação dos efeitos da tutela ao autor, diante do abuso do direito de defesa. Assim, ambos os artigos trazem mecanismos aptos ao combate à questão da morosidade, assegurando, assim, isonomia de tratamento processual.

Percorrendo os três passos para a investigação da harmonização entre a distinção concretizada e a determinação contida no princípio da isonomia. Em primeiro lugar, prevê a análise do objeto escolhido como fator de discriminação. Num segundo momento, imperioso verificar a ocorrência de um liame lógico entre o fator colocado como critério de discriminação e a desigualdade estabelecida no tratamento jurídico diversificado. Finalmente, salienta o autor a necessidade de se verificar a conformidade entre essa correlação lógica e a preocupação com os valores do sistema constitucional em exame. O emprego desses três critérios, sustenta o autor, constitui mecanismo hábil para se concluir pela existência ou não de ofensa ao princípio da isonomia. ${ }^{381}$

Fazendo a conformação do artigo 285-A com os três passos para a investigação da harmonização entre a distinção concretizada e a determinação contida no princípio da isonomia sugerida por Celso Antônio Bandeira de Mello, temos o que segue.

No primeiro passo, constatamos que o artigo 285-A do $\mathrm{CPC}$, destina-se às demandas multitudinárias, não comportando, assim, singularização de um sujeito a ser colocado sob a incidência de um regime peculiar.

Em um segundo momento, investigando a correlação lógica entre o descrímen e a desequiparação com base nele levada a efeito, verificamos a existência de uma ponderação justificável para o tratamento diferenciado dispensado a esse fenômeno massificador. A aplicação adequada de precedente jurisdicional do juízo, nas situações ali ventiladas, garante uma resposta da atividade jurisdicional com o mínimo de atos praticados e num prazo razoável.

\footnotetext{
${ }^{381}$ MELLO, Celso Antônio Bandeira de. O conteúdo jurídico do princípio da igualdade, cit., p. 27-28.
} 
Existente esse liame lógico, podemos concluir que há harmonia entre a discriminação proposta e os interesses constitucionalmente protegidos tais como a celeridade, duração razoável do processo, segurança jurídica, entre outros.

Finalizado esse raciocínio em três passos, temos que a regra do art. 285-A do CPC não tem nenhuma influência negativa sobre o princípio da igualdade ou isonomia.

\subsection{Princípio da segurança jurídica}

O princípio da segurança jurídica pode ser considerado como um dos preceitos basilares do Estado democrático de Direito. ${ }^{382}$ Referido princípio reveste-se de extrema relevância no nosso atual contexto social. Com efeito, com o pós-guerra, a sociedade passou a enxergar a necessidade de ter um ordenamento que, a par de prever direitos e garantias fundamentais, fosse aplicável não só à sociedade em geral, mas também aos seus governantes, evitando-se, assim, o exercício arbitrário do poder político. ${ }^{383}$

A segurança constitui traço imanente ao direito, tanto nas relações entre indivíduos, como nas relações destes com o Estado. Daí porque faz sentido a afirmação no sentido de que "o direito põe-se para dar segurança, pois, para se ter insegurança, direito não é necessário.” 384

Na mesma toada, Almiro do Couto e Silva sustenta que justiça e segurança são valores fundamentais intimamente ligados, complementares entre si, sendo que somente aparentemente se contrapõe. Ressalta o autor que por vezes a segurança, no caso concreto configura o próprio justo. Conclui, assim, “que as antinomias e conflitos entre justiça e

\footnotetext{
${ }^{382}$ CANOTILHO, José Joaquim Gomes. Direito constitucional e teoria da Constituição. 6. ed. Coimbra: Almedina, 2003. p. 257.

${ }^{383}$ Acerca do papel da segurança jurídica nesse atual contexto, destaca Luís Eduardo Schoueri que "enquanto o pensamento baseado no Estado de direito valorizará a segurança jurídica concernente à certeza dos direitos, abrangendo a elaboração, a interpretação e a própria positivação do ordenamento, penetrando também na linguagem jurídica em busca da clareza e da certeza e no próprio funcionamento dos órgãos do Estado, o Estado Social de Direito trará novas CORES ao mesmo valor da segurança jurídica, onde se prestigiará não mais a mera manutenção de regras, mas a previsibilidade da atuação do Estado quando da intervenção no domínio econômico, conforme os ditames da ordem econômica firmados pelo constituinte, o que implicará a necessária consistência dessa atuação em relação à própria política econômica adotada". (SCHOUERI, Luís Eduardo. Segurança na ordem tributária nacional e internacional: tributação do comércio exterior. In: II CONGRESSO NACIONAL DE ESTUDOS TRIBUTÁRIOS: [segurança jurídica na tributação e estado de direito]. Congresso Nacional de Estudos Tributários (2.: 2004: São Paulo, SP). Coordenação: Eurico Marcos Diniz de Santi. São Paulo: Noeses, 2005. p. 383).

${ }^{384}$ Cf. ROCHA, Cármen Lúcia Antunes (Coord.). Constituição e segurança jurídica: direito adquirido, ato jurídico perfeito e coisa julgada. Belo Horizonte: Fórum, 2004. p. 168.
} 
segurança jurídica, fora do mundo platônico das ideias puras, alheias e indiferentes ao tempo e à história, são falsas antinomias e conflitos". ${ }^{385}$

A Constituição Federal de 1988 não proclama o princípio da segurança jurídica de forma expressa, mas o faz somente de modo implícito. Tal princípio permeia todo o escrito constitucional, podendo ser, inclusive, deduzido a partir dos demais princípios ali previstos.

Com efeito, o princípio da segurança jurídica pode ser deduzido da análise dos diversos dispositivos constitucionais, dentre os quais destacamos o artigo $5^{\circ}$, XXXVI, onde se lê "a lei não prejudicará o direito adquirido, o ato jurídico perfeito e a coisa julgada", artigo 5', II, que prevê "ninguém será obrigado a fazer ou deixar de fazer alguma coisa senão em virtude de lei”, art. $5^{\circ}$, incisos XXXIX e XL que tratam acerca da legalidade e irretroatividade das leis penais, bem como o art. 150, III, alíneas $a$ e $b$ que tratam das regras da irretroatividade e da anterioridade em matéria tributária. O preâmbulo da Constituição Federal brasileira prescreve, ainda, entre outros, a segurança e a justiça como valores supremos norteadores do Estado democrático do direito.

Em que pese previsto implicitamente, importante salientar que o princípio da segurança jurídica exerce igual autoridade no ordenamento jurídico quando comparado com aqueles arrolados explicitamente. ${ }^{386}$

O princípio da segurança jurídica, também de forma implícita, aparece nos ordenamentos constitucionais de Portugal (na enunciação dos fundamentos do Estado de direito democrático, do artigo $2^{\circ}$ ), dos Estados Unidos (por intermédio da exigência de não retroatividade e do acatamento à cláusula do devido processo legal), sendo que também o ordenamento italiano busca valorizar referido princípio. ${ }^{387}$

\footnotetext{
${ }^{385}$ SILVA, Almiro do Couto. Princípios da legalidade da administração pública e da segurança jurídica no Estado de direito contemporâneo. Revista de Direito Público, São Paulo, v. 20 n. 84, p. 46-47, out./dez. 1987.

${ }^{386}$ Não é outro o entendimento de Souto Maior Borges, para o qual "o princípio implícito não difere senão formalmente do expresso. Têm ambos o mesmo grau de positividade. Não há positividade "forte" (a expressa) e outra "fraca" (a implícita). Um princípio implícito pode muito bem ter eficácia (=produzir efeitos) muito mais acentuada do que um princípio expresso". (BORGES, José Souto Maior. O princípio da segurança jurídica na criação e aplicação do tributo. Revista de Direito Tributário, n. 63, p. 207, jan./ mar. 1994).

${ }^{387}$ Cf. THEODORO JÚNIOR, Humberto. A onda reformista do Direito Positivo e suas implicações com o princípio da segurança jurídica. Revista de Doutrina da $4^{a}$ Região. Porto Alegre, ano 24, n. 14, set. 2006. Disponível <http://www.revistadoutrina.trf4.jus.br/index.htm?http://www.revistadoutrina.trf4.jus.br/artigos/edicao014/ Humberto_Junior.htm>. Acesso em: 30 out. 2012.
} 
No plano infraconstitucional do ordenamento jurídico pátrio, a segurança jurídica, de maneira expressa, é encontrada no art. $2^{\circ}$, da Lei $n^{\circ} 9.784^{388}$, de 29 de janeiro de 1999 , no art. 27 , da Lei $n^{\circ} 9.868^{389}$, de 11 de novembro de 1.999 e, também, no art. 11 da Lei $n^{\circ}$ $9.882^{390}$, de 03 de dezembro de 1.999 .

Debruçando-se sobre o assunto, o Ministro José Augusto Delgado, destaca que a segurança jurídica, em sentido genérico, configura “a garantia assegurada pela Constituição Federal ao jurisdicionado para que uma determinada situação concreta de direito não seja alterada, especialmente quando sobre ela exista pronunciamento judicial”. 391

Desta maneira, o princípio da segurança jurídica se mostra como ente essencial para a solidificação da confiança que deve ser depositada no direito, consumando-se, dentre outros, através da irretroatividade da lei, do devido processo legal, do direito adquirido. Através dela é possível conferir estabilidade às relações jurídicas e proteger os indivíduos de variações repentinas em posições consolidadas no tempo.

Destaca Canotilho, ilustre autor português, que a segurança jurídica influencia todo o direito, atuando sobre os atos normativos, atos jurisdicionais e, também, em relação aos atos da Administração. ${ }^{392}$

\footnotetext{
${ }^{388}$ Prescreve o art. $2^{\text {o: }}$ "A Administração Pública obedecerá, dentre outros, aos princípios da legalidade, finalidade, motivação, razoabilidade, proporcionalidade, moralidade, ampla defesa, contraditório, segurança jurídica, interesse público e eficiência."

${ }^{389}$ Dispõe o art. 27: "Ao declarar a inconstitucionalidade de lei ou ato normativo, e tendo em vista razões de segurança jurídica ou de excepcional interesse social, poderá o Supremo Tribunal Federal, por maioria de dois terços de seus membros, restringir os efeitos daquela declaração ou decidir que ela só tenha eficácia a partir de seu trânsito em julgado ou de outro momento que venha a ser fixado".

${ }^{390}$ Prevê o art. 11: "Ao declarar a inconstitucionalidade de lei ou ato normativo, no processo de argüição de descumprimento de preceito fundamental, e tendo em vista razões de segurança jurídica ou de excepcional interesse social, poderá o Supremo Tribunal Federal, por maioria de dois terços de seus membros, restringir os efeitos daquela declaração ou decidir que ela só tenha eficácia a partir de seu trânsito em julgado ou de outro momento que venha a ser fixado".

${ }^{391}$ DELGADO, José Augusto. O princípio da segurança jurídica: supremacia constitucional. Brasília, DF, 2005. Disponível em: <http://bdjur.stj.gov.br/dspace/handle/2011/448>. Acesso em: 31 out. 2012.

${ }^{392}$ Em suas palavras: "(1) relativamente a actos normativos - proibição de normas retroactivas restritivas de direitos ou interesses juridicamente protegido; (2) relativamente a actos jurisdicionais inalterabilidade do caso julgado; (3) em relação a actos da administração - tendencial estabilidade dos casos decididos através de actos administrativos constitutivos de direitos". (CANOTILHO, José Joaquim Gomes. Direito constitucional e teoria da Constituição, cit., p. 257). No mesmo sentido, apregoa Humberto Theodoro Júnior que "a submissão ao princípio de segurança jurídica não é exclusiva do legislador, mas cabe a todos os detentores do poder público. Tanto a Administração como a Justiça (especialmente esta) desempenham relevante papel na preservação da segurança jurídica, de sorte que suas decisões não podem aplicar as leis novas segundo interpretações ofensivas aos critérios da razoabilidade e proporcionalidade e com quebra da confiança incutida aos agentes dos atos jurídicos, quanto aos efeitos normais esperados, segundo as normas e interpretações vigentes ao tempo de sua prática". (THEODORO JÚNIOR, Humberto. A onda reformista do Direito Positivo e suas implicações com o princípio da segurança jurídica, cit.).
} 
Feitas estas considerações iniciais, convém tratar dos diversos conteúdos do princípio da segurança jurídica.

A segurança jurídica apresenta duplo aspecto: um objetivo e outro subjetivo. O primeiro está voltado à proteção da trilogia direito adquirido, ato jurídico perfeito e coisa julgada e envolve o apoio que o Estado deve conceder aos cidadãos, principalmente no que se refere a mudanças na política estatal que possam prejudicar ou fragilizar seus direitos. ${ }^{393}$

O segundo aspecto, de ordem subjetiva, diz que a confiança dos indivíduos depositada na atuação estatal, em todos os seus âmbitos, deve ser preservada. Nesse sentido, Almiro do Couto e Silva esclarece que nos dias atuais, em especial no direito estrangeiro, apesar de atentos à intima relação entre esses dois aspectos, tem-se acolhido a tese da presença de dois princípios diversos: "princípio da segurança jurídica quando designam o que prestigia o aspecto objetivo da estabilidade das relações jurídicas, e em princípio da proteção à confiança, quando aludem ao que atenta para o aspecto subjetivo". 394

Elucidando esses dois princípios, o da segurança jurídica e o da proteção de confiança, temos que ambos "apontam basicamente para (1) a proibição de leis retroactivas; (2) a inalterabilidade do caso julgado, (3) a tendencial irrevogabilidade de actos administrativos constitutivos de direitos". 395

No tocante especificamente ao princípio da segurança jurídica, temos que esta se manifesta em torno de dois conceitos essenciais: previsibilidade e estabilidade. A previsibilidade traz a necessidade da verificação de três condições, quais sejam: prévio conhecimento das normas, possibilidade de sua compreensão e interpretação, bem como efetividade do sistema jurídico. No tocante à estabilidade, aspecto objetivo, destaca-se a necessidade de continuidade das normas e de respeito aos precedentes. ${ }^{396}$

\footnotetext{
${ }^{393}$ SILVA, Almiro do Couto. O princípio da segurança jurídica (proteção à confiança) no direito público brasileiro e o direito da administração pública de anular seus próprios atos administrativos: o prazo decadencial do art. 54 da Lei do Processo Administrativo da União (Lei $\mathrm{n}^{\circ}$ 9.784/99). Revista da Procuradoria-Geral do Estado [do Rio Grande do Sul], Porto Alegre, v. 27, n. 57, p. 36, 2004. Disponível em <http://www.pge.rs.gov.br/upload/revista_pge_57_sup.pdf>. Acesso em: 30 out. 2012.

${ }^{394}$ SILVA, Almiro do Couto. O princípio da segurança jurídica (proteção à confiança) no direito público brasileiro e o direito da administração pública de anular seus próprios atos administrativos: o prazo decadencial do art. 54 da Lei do Processo Administrativo da União (Lei no 9.784/99), cit., p. 36.

${ }^{395} \mathrm{Cf}$. CANOTILHO, José Joaquim Gomes. Direito constitucional e teoria da Constituição, cit., p. 257.

${ }^{396}$ MARINONI, Luiz Guilherme. Princípio da segurança dos atos jurisdicionais. In: TORRES, Ricardo Lobo; KATAOBA, Eduardo Takemi; GALDINO, Flavio (Org.). Dicionário de princípios jurídicos. Rio de Janeiro: Elsevier, 2011. p. 1226-1230.
} 
O conceito de segurança jurídica não é estanque, sofrendo desenvolvimento constante pela doutrina e jurisprudência, em virtude de seu caráter de direito fundamental. Tal princípio, ao lado da certeza jurídica, configura um dos aspectos basilares do Estado de Direito, sendo ambos “absolutamente necessários para que a função estabilizadora do Poder Judiciário, a quem a Constituição Federal lhe concede a competência para de julgar os litígios, seja desenvolvida com estabilidade e credibilidade”. ${ }^{397}$

José Afonso da Silva assinala que a segurança no direito pode ser considerada como gênero, da qual são espécies a segurança do direito e a segurança jurídica propriamente dita. A segurança do direito configura fundamento de validade do direito positivo, guardando intrínseca relação com a Constituição Federal. A segurança jurídica, por sua vez, assume o papel de garantia, visando dar proteção às relações. Feitas essas considerações, destaca o autor que nossa Carta Magna vislumbra quatro formas de segurança jurídica: "a segurança como garantia; a segurança como proteção dos direitos subjetivos; a segurança como direito social e a segurança por meio do direito”. ${ }^{398}$

É imperioso destacar que o princípio da segurança jurídica apresenta facetas diversas, albergando em si uma gama variada de conteúdos. De modo geral, espera-se que o cidadão tenha conhecimento do direito vigente, saiba as condutas que dele o Estado espera, daí a necessidade da relação de confiança, que se materializa com a previsão de legalidade e irretroatividade das normas. Ademais, é preciso que as normas sejam certas, isto é, sejam claras e inteligíveis quanto ao seu conteúdo e com instrumentos suficientemente eficazes para dar-lhes concretude. É necessária, ainda, a presença de um órgão específico, independente, que seja capaz de refrear qualquer tipo de arbitrariedade.

Tornou-se lugar comum em nosso ordenamento jurídico a existência de decisões divergentes para diversos casos com questões semelhantes. Essa imprevisibilidade do Judiciário compromete, muitas vezes, seu papel de pacificador dos conflitos de interesses. Reconhecemos que cada juiz tem convicções pessoais próprias, mas deve-se buscar, sempre que possível, coerência no julgamento dos casos semelhantes. ${ }^{399}$ Não se está a

\footnotetext{
${ }^{397}$ Cf. DELGADO, José Augusto. O princípio da segurança jurídica: supremacia constitucional, cit.

${ }^{398}$ SILVA, José Afonso da. Da Constituição e segurança jurídica. Fórum Administrativo: Direito Público, Belo Horizonte, v. 6, n. 59, p. p. 6653-6654, jan. 2006.

${ }^{399}$ Luiz Guilherme Marinoni em crítica cítrica exalta que: "No direito brasileiro contemporâneo há uma absurda e curiosa não percepção da contradição existente entre a mitificação do duplo grau e a ausência de respeito às decisões dos tribunais superiores. De forma acrítica, ao mesmo tempo em que se vê na obrigatoriedade dos precedentes um atentado contra a liberdade do juiz, celebra-se o duplo grau de jurisdição com garantia de justiça. Os juízes pensam que exercem poder quando julgam como desejam, mas não percebem que não têm poder para decidir (sozinhos) nem sequer uma ação de despejo fundada
} 
defender um direito estático, mas sim um direito capaz de se adequar às diversas realidades que permeiam a sociedade.

Ao aplicar o art. 285-A do CPC o julgador deve ser sensível para que os casos assemelhados recebam o mesmo tratamento, contudo, é preciso, na mesma medida, que os casos diferentes recebam tratamento diferenciado. $\mathrm{O}$ magistrado, ao se deparar com um caso concreto, analisando prudentemente se a situação posta apresenta os requisitos autorizadores da previsão legal, deve fazer uso da solução paradigmática; caso contrário, deverá prosseguir no normal fluxo do processo.

Dirley da Cunha Júnior já teve a oportunidade de preconizar que a segurança jurídica “impõe aos poderes públicos o respeito à estabilidade das relações jurídicas já constituídas e a obrigação de antecipar os efeitos das decisões que interferirão nos direitos e liberdades individuais e coletivas". 400

O julgamento com base no art. 285-A do CPC não importa em qualquer afronta ao princípio da segurança jurídica, visto que o que ele almeja é justamente oferecer aos jurisdicionados, ainda mais se tiver por base também decisões dominantes e súmulas de Tribunais Superiores, uma maior previsibilidade no que toca ao entendimento do juízo sobre um determinado assunto, fazendo tão somente antecipar uma decisão que seria proferida, ao final, da mesma maneira, não dispensando, contudo a necessidade de motivação do julgado. ${ }^{401}$

Na mesma toada, não é correto falar em falta de publicidade da decisão, uma vez que os julgados, salvo exceções contidas na própria lei, são públicos, a teor do que dispõe o art. 93, IX da Constituição Federal. Ademais, em que pese o julgado proferido com fundamento no art. 285-A se utilize das fundamentações de sentenças prolatadas em outros feitos, a decisão não perde sua autonomia. Isto porque, “não se pode olvidar que o

em falta de pagamento ou uma ação ressarcitória derivada de acidente de trânsito, e, além disto, que as suas sentenças, em regra, não interferem na vida dos litigantes”. (MARINONI, Luiz Guilherme. Princípio da segurança dos atos jurisdicionais, cit., p. 1231).

${ }^{400}$ CUNHA JÚNIOR, Dirley. Curso de direito constitucional. 2. ed. Salvador: Ed. Jus Podivm, 2008. p. 678.

${ }^{401}$ Comungando de tal entendimento, confira-se: "É óbvio que não se pode falar em sentença vinculante, eis que a atividade do juiz, nesse tocante, é facultativa; e ao contrário do que afirma a Ordem dos Advogados do Brasil, prestigia-se a segurança, na medida em que o magistrado não irá proferir sentença casuística, contrária a entendimento anterior firmado em situação absolutamente semelhante, unicamente para o fim de beneficiar interesses não declarados." (CAVALCANTE, Mantovanni Colares. A sentença liminar de mérito do art. 285-A do Código de Processo Civil e suas restrições, cit., p. 98). No mesmo sentido: “ $O$ novel art. 285-A do CPC, outrossim, diferentemente do sustentado na ação direita de inconstitucionalidade, solidifica a segurança jurídica, na medida em que prestigia a convergência e igualdade na tutela jurisdicional de casos similares, concretizando, assim, o princípio da isonomia." (PINTO, Fernanda Guedes. As ações repetitivas e o novel art. 285-A do CPC (racionalização para as demandas de massa), cit., p. 134). 
magistrado apenas expõe raciocínio puramente jurídico, outrora firmado e reiterado, em causa idêntica". ${ }^{402}$

No mesmo sentido foi o parecer do Procurador-Geral da República que, nos autos da ADIn 3.695, expressamente afirmou que "o art. 285-A fortalece a segurança jurídica, na medida em que assegura maior previsibilidade das sentenças a serem prolatadas pelos juízos monocráticos”.

Denis Donoso também se filia àqueles que não concordam com a tese de inconstitucionalidade da norma por afronta à segurança jurídica e adiciona a estes argumentos o fato de que, realizado uma interpretação conforme do texto legal, "não há elemento surpresa no julgamento pela técnica do art. 285-A, porque é previsível a forma como julgará o órgão monocrático, o que de resto encontra amparo na tendência mais moderna do processo de supervalorização do precedente judicial”. ${ }^{403}$

Desse modo, não merece acolhida o argumento trazido pelo Conselho Federal da Ordem dos Advogados do Brasil (CFOAB), na ADIn 3695, de que o art. 285-A ofende a segurança jurídica, na medida em que possibilita o encurtamento do caminho normal do processo utilizando-se da repetição da sentença proferida em outro caso, cuja publicidade para os jurisdicionados que não participaram naquele feito inexiste.

Temos, assim, que a segurança jurídica, lastreada nos conceitos de previsibilidade e de estabilidade, é prestigiada pelo novel art. 285-A do CPC, não merecendo prevalecer, neste ponto, a alegada inconstitucionalidade, uma vez que se exige do juiz a demonstração da semelhança do caso que está sendo apreciado com aquele anteriormente julgado, abrindo-se, ainda, a possibilidade de interposição de recurso em face de referida decisão.

\subsection{Princípio do acesso à justiça}

O direito de ação é compreendido como o direito de provocar a tutela jurisdicional. É a resposta estatal à supressão da justiça de caráter privado. Tendo em vista que se

\footnotetext{
${ }^{402}$ Cf. MENEZES, Iure Pedroza. O novo art. 285-A do CPC: reflexões acerca de sua constitucionalidade. Jus Navigandi, Teresina, ano 12, n. 1479, 20 jul. 2007. Disponível em: <http://jus.com.br/revista/texto/10165>. Acesso em: 5 nov. 2012.

${ }^{403}$ DONOSO, Denis. Julgamento prévio do mérito: análise do art. 285-A do CPC, cit., p. 59.
} 
reconhecem direitos, mas se impede o exercício da autotutela, permite-se que o particular movimente a máquina judiciária para dirimir os conflitos, buscando a paz social.

$\mathrm{O}$ artigo $5^{\circ}, \mathrm{XXXV}$, da Constituição Federal, assegura que "A lei não excluirá da apreciação do Poder Judiciário lesão ou ameaça a direito”. ${ }^{404}$ A inserção constitucional dessa garantia é emanação da teoria abstrata do direito de ação. Não se pode aprioristicamente vedar o acesso jurisdicional, motivo pelo qual se defere livre e incondicionalmente o debate em juízo, impondo-se ao Estado o dever de a todos ouvir, dando em cada caso solução.

O direito de ação foi visto por um longo período como um direito meramente formal e abstrato, um simples direito de acesso aos órgãos judiciais. Entretanto, atualmente, tendo como marco a obra de Mauro Cappelletti e Bryant Garth, o movimento pelo acesso à justiça ganhou nova roupagem e papel de destaque no direito processual, através das denominadas ondas renovatórias. ${ }^{405}$

De fato, hoje não se fala acerca da mera possibilidade do titular de um direito reclamá-lo em juízo, mas também do direito a um processo efetivo e justo. O movimento por acesso à justiça trata de analisar e procurar os caminhos para superar os obstáculos que tornam tão distante para grande parcela da população a obtenção da prestação jurisdicional adequada.

A Constituição Brasileira de 1988, marcada pela opção de participação democrática, traz na garantia do acesso à Justiça um caráter transformador da sociedade, uma vez que permite a concretização de direitos fundamentais, antes tão distante da sociedade como um todo. ${ }^{406}$

\footnotetext{
${ }^{404}$ Saliente-se que a garantia da inafastabilidade da tutela jurisdicional foi introduzida de forma expressa no direito brasileiro na Constituição Federal de 1946, que dispunha em seu art. 141, parágrafo 4: “a lei não excluirá da apreciação do Poder Judiciário qualquer lesão de direito individual”.

${ }^{405}$ A primeira onda visou a ampliação da assistência judiciária, buscando afastar os obstáculos decorrentes da pobreza. A segunda, buscou dar luz às demandas coletivas, por intermédio da legitimação de entidades para a tutela dos interesses difusos e individuais homogêneos. A terceira onda, por seu turno, versa sobre a simplificação, racionalização e agilização processuais, bem como sobre os meios alternativos. A doutrina moderna, convém mencionar, não se conforma com a simples eficácia jurídica da norma processual, buscando a eficácia social. (CAPPELLETTI, Mauro; GARTH, Bryant. Acesso à justiça, cit., p. 31).

${ }^{406}$ Acerca do assunto, aduz Arruda Alvim que "O legislador foi sensível ao fenômeno da ascenção das massas que, em certa escala visam mesmo a própria ascenção a uma fatia do poder social, ou, ao menos, exercício de influência política nos rumos do país; teve consciência de que isto gera tensões sociais e, por isto, a forma encontrada foi a de uma tentativa ampla de 'calibrar' interesses, especialmente tendo em vista o acesso à sociedade institucionalizada de grupos que, anteriormente, só de forma "nominal" ou "marginal" integravam a sociedade." (ALVIM, Arruda. Princípios constitucionais na Constituição Federal de 1988 e o acesso à justiça. Revista do Advogado, São Paulo, n. 34, p. 6, jul. 1991).
} 
De fato, como bem esclarece José Roberto dos Santos Bedaque, "muito mais do que prever mera formulação de pedido ao Poder Judiciário, a Constituição da República garante a todos o efetivo acesso à ordem jurídica justa, ou seja, coloca à disposição de todas as pessoas mecanismo destinado a proporcionar a satisfação do direito". 407

Com efeito, de nada adianta a simples previsão de direitos desprovida de meios suficientes para fazê-los valer, daí a relevância da atuação estatal para garantir a igualdade também em âmbito material e a efetividade dos direitos previstos constitucionalmente, disponibilizando instrumentos adequados e eficientes de resolução dos conflitos.

O conceito de acesso à justiça não é universal e tampouco pode ser analisado apenas pelo contexto judiciário, sofrendo, ao longo do tempo, modificações no seu conteúdo de acordo com os modelos culturais, políticos e econômicos da sociedade. ${ }^{408}$

Do exposto até o momento, constata-se que há muito se encontra ultrapassada a estrita visão de simples acesso aos diversos órgãos integrantes do Poder Judiciário. Isto porque o princípio do acesso à justiça não se esgota em seu aspecto formal, isto é, de simples acesso ao Poder Judiciário, encontrando guarida na busca de efetivação dos direitos fundamentais. ${ }^{409}$

Convém ressaltar o aspecto dual do princípio do acesso à justiça: é este, a um só tempo, um direito fundamental que necessita ser concretizado e um caminho para a realização de outros direitos fundamentais. Contudo, esse princípio extrapola as fronteiras judiciais para encontrar arrimo na necessidade de efetivação, ainda que fora da estrutura oficial estatal, dos direitos.

Em que pese sua condição de direito fundamental, o princípio do acesso à justiça não é absoluto, existindo restrições ou condicionamentos para sua utilização. Com efeito, há situações que podem obstar, ainda que por um dado tempo, a possibilidade de se submeter uma causa específica ao Poder Judiciário.

\footnotetext{
${ }^{407}$ BEDAQUE, José Roberto dos Santos. Garantia da amplitude de produção probatória. In: CRUZ E TUCCI, José Rogério (Coord.). Garantias constitucionais do processo civil. São Paulo: Ed. Revista dos Tribunais, 1999. p. 151.

${ }^{408}$ Cf. MANCUSO, Rodolfo de Camargo. Acesso à justiça: condicionantes legítimas e ilegítimas. São Paulo: Ed. Revista dos Tribunais, 2011. p. 32-33.

${ }^{409}$ Em sentido semelhante, Nelson Nery Júnior argumenta que "pelo princípio constitucional do direito de ação, além do direito ao processo justo, todos têm direito de obter do Poder Judiciário a tutela jurisdicional adequada. Não é suficiente o direito à tutela jurisdicional. É preciso que essa tutela seja adequada, sem o que estaria vazio de sentido o princípio”. (NERY JÚNIOR, Nelson. Princípios do processo na Constituição Federal: processo civil, penal e administrativo. 9. ed. São Paulo: Ed. Revista dos Tribunais, 2009. p. 172).
} 
Anote-se que não há que se falar em uma impossibilidade total e absoluta de acesso à justiça, em todo e qualquer caso, por flagrante inconstitucionalidade. O que ser quer dizer é que há limitações constitucionais e infraconstitucionais impostas ao princípio do acesso à justiça, as quais devem ser analisadas à luz de outros princípios importantes, como por exemplo, o princípio da proporcionalidade. Nesse sentido, o art. $217, \S 1^{\circ}, \mathrm{CF}$ prevê a necessidade de prévio esgotamento das instâncias da justiça desportiva para ajuizamento de demanda junto ao Poder Judiciário, o art. 142, $\$ 2^{\circ}$, da CF, veda a utilização do habeas corpus quando se pretender discutir punições disciplinares militares.

Em que pese todos os esforços depreendidos, o pleno acesso à justiça ainda está distante do modelo ideal, necessitando de aprimoramentos. As barreiras que dificultam a plena aplicação desse princípio são de ordem social, econômico e cultural, dentre as quais podemos citar a carência de recursos econômicos e capacidade jurídica, descrença da sociedade no judiciário, falta de conscientização em relação aos direitos difusos e coletivos, além de aspectos psicológicos e ideológicos atrelados à noção de justiça e de poder judiciário.

Mister salientar que todos os obstáculos mencionados merecem reflexão e atuam em conjunto como complicadores da democratização da justiça. Assim, deve-se reconhecer a insuficiência dos direitos individuais e a necessidade de se aparelhar a sociedade civil de elementos de organização e defesa de direitos sociais. ${ }^{410}$

É sensitivo, ainda, que o ordenamento jurídico precisa ser reestruturado a fim de atender aos anseios dessa nova ordem estatal. Assim, nota-se ser necessário o aparelhamento do Poder Judiciário de mecanismos que possibilitem a obtenção de soluções céleres para os litígios que lhe são postos.

Ademais, em que pesem todas essas concepções, o acesso à justiça não pode ser visto apenas como acesso à entrada no sistema, mas como acesso à entrada e à saída, sem dilações indevidas, sob pena de vedar definitivamente o real acesso à justiça. A

\footnotetext{
${ }^{410}$ Registre-se, a esse respeito, lição de Carlos Simões Fonseca: "O cunho eminentemente individualista do processo, traduzido apenas nos direitos individuais simples, limitava muito a representatividade dos interesses de grupos em juízo, por falta de instrumentos jurídicos adequados. Nessa linha, a nova concepção do processo caminhou no sentido de alargar a proteção desses novos direitos, mediante a introdução, no ordenamento, de mecanismos que viabilizassem a defesa dos direitos chamados "difusos", acompanhando a tendência de coletivização da tutela, a partir de demandas envolvendo uma gama maior de sujeitos numa mesma ação". (FONSECA, Carlos Simões. Sincretismo processual e acesso à justiça. São Paulo: LTr, 2009. p. 42).
} 
morosidade, tal como já tivemos a oportunidade de explicitar no presente trabalho, constitui outra barreira ao acesso à Justiça.

O princípio do acesso à justiça encontra intima ligação com outros princípios de igual importância, quais sejam: os princípios da economia, efetividade e celeridade processual.

Segundo o princípio da economia processual, os atos processuais devem ser praticados sempre da forma menos onerosa possível às partes, uma vez que "o desvio da atividade processual para os atos onerosos, inúteis e desnecessários gera embaraço à rápida solução do litígio, tornando demorada a prestação jurisdicional. Justiça tardia é, segundo consciência geral, justiça denegada". 411

O princípio da efetividade, por sua vez, visa a dar uma solução mais justa e mais rápida às demandas. Para que o processo seja efetivo, deve estar predisposto a proporcionar os melhores resultados, por meio de mecanismos legais que viabilizem a entrega do bem da vida. A eficácia do sistema processual será medida, por conseguinte, em função de sua utilidade para o ordenamento jurídico material e para a pacificação social ${ }^{412}$

$\mathrm{O}$ fator tempo também está intimamente ligado à ideia de efetividade. O princípio da razoável duração do processo, também conhecido como princípio da celeridade, foi introduzido ao art. $5^{\circ}$ de nossa Carta Constitucional pela EC n. 45, de 2004. Assim prescreve o inciso LXXVIII: “a todos, no âmbito judicial e administrativo, são assegurados a razoável duração do processo e os meios que garantam a celeridade de sua tramitação". 413

\footnotetext{
${ }^{411}$ Cf. THEODORO JÚNIOR, Humberto. Curso de direito processual civil: teoria geral do direito processual civil e processo de conhecimento, cit., v. 1, p. 42-43.

${ }^{412}$ De acordo com os ensinamentos de Gerson Lacerda Pistori: "o princípio orientador da efetividade se interrelaciona, convive, alterna, se sobrepõe ou se coloca sob o princípio do devido processo legal, este outro princípio orientador, mas sob o prisma das partes, da cidadania. Isso se dá em razão de que se só houvesse o enfoque do princípio do devido processo legal, com a importância do contraditório, duplo grau de jurisdição e outros princípios decorrentes do princípio do devido processo legal, teríamos uma conduta de âmbito remissivo, recorrente e de contínuo direito das partes se manifestarem, dando-se destaque às partes em detrimento da jurisdição e sua necessária função efetiva de dar atendimento ao que se pede como direito e ao dever-poder do Estado de atender ao que se pede tendo em conta sua postura democrática de direito. Teríamos nesse caso apenas o enfoque das balanças do direito, como símbolo, mas sem a presença dos pesos que dão o ajustamento do equilíbrio real, na busca do justo. A efetividade, portanto, possui a função dos pesos, que se colocam nas balanças do princípio do devido processo legal". (PISTORI, Gerson Lacerda. A efetividade como um princípio orientador. Revista do Tribunal Regional do Trabalho da $15^{a}$ Região, Campinas, São Paulo, n. 13, 2000, p. 51. Disponível em: $<$ http://trt15.gov.br/escola_da_magistratura/Rev13Art3.pdf>. Acesso em: 4 dez. 2008).

${ }^{413}$ Há muito, já dizia Carnelutti que a duração do processo agrava progressivamente o peso sobre as costas da parte mais fraca, o que implica a própria negação a esta do acesso à justiça. (CARNELUTTI, Francesco. Diritto e processo. Napoli: Morano, 1958. p. 357).
} 
Cada vez mais tem se buscado o aprimoramento do serviço jurisdicional prestado a fim de que o processo atinja seu ideal com o menor desgaste possível. Em face de tal princípio, foram erigidas normas como a regra prevista no artigo 285-A do CPC.

Sustenta-se que o art. 285-A do CPC contradiz o princípio do acesso à justiça, nas situações em que a sentença liminar esteja baseada em súmula da jurisprudência dominante do STF ou do STJ, pois a apelação não será recebida (CPC art. 518. § $\left.1^{\circ}\right)$. Deste modo, não se poderá propor novamente a discussão no grau superior de jurisdição, isto é, o autor da ação não teria acesso a uma discussão judicial ampla de seu pedido nem em primeiro, nem em segundo grau de jurisdição. ${ }^{414}$

Contudo, este não nos parece ser o melhor entendimento. Já tivemos a oportunidade de expor, no presente trabalho, opinião no sentido de que análise em conjunto do sistema leva justamente a posicionamento favorável à prolação de sentença de improcedência liminar do pedido que esteja em consonância com entendimento sumulado do STF ou do STJ. $^{415}$

Quanto ao direito de ação, como bem referiu Fernanda Guedes Pinto, não podemos considerá-lo de maneira tão abstrata e uniforme que não leve em consideração o direito material a ser protegido:

A concepção da ação, fundada na teoria dos direitos fundamentais, deve estar preocupada com a tutela adequada dos direitos materiais, podendo ser construída no caso concreto, a partir da pretensão à tutela jurisdicional do direito e da causa de pedir. Assim, o direito de ação está voltado à obtenção da tutela dos direitos materiais. Se a pretensão à tutela jurisdicional é inviável, pois a causa de pedir remota revela que a matéria é unicamente de direito e que em outros casos idênticos o órgão julgador já se manifestou contrariamente à pretensão, promover a citação para simplesmente se desincumbir de um requisito formal é descumprir a Constituição, colocando obstáculos não razoáveis ao acesso à justiça. ${ }^{416}$

Não se vislumbra óbice ao direito de ação pela nova autorização para o julgamento de plano acerca do mérito, nos termos do art. 285-A do CPC, uma vez que o processo somente tem seu andamento abreviado por total desnecessidade do prosseguimento do feito e desde que ocorra a persuasão do magistrado, no contato inicial com a causa, ao

\footnotetext{
${ }^{414}$ CÂMARA, Alexandre Freitas. Lições de direito processual civil, cit., v. 1, p. 335-336.

${ }^{415}$ Do mesmo sentir: POITTEVIN, Ana Laura González. O art. 285-A do CPC e os embargos de declaração, cit., p. 619-620.

${ }^{416}$ PINTO, Fernanda Guedes. As ações repetitivas e o novel art. 285-A do CPC (racionalização para as demandas de massa), cit., p. 135.
} 
observar que a matéria é preponderantemente de direito com fatos previamente provados e não há, portanto, debate de ordem fática, bem como a existência no mesmo juízo de julgamento de total improcedência da matéria em casos idênticos. ${ }^{417}$

O entendimento de que o disposto no art. 285-A, do CPC, afastaria o exercício do direito de ação ou ofenderia o princípio de acesso à justiça não há como predominar, como poderia parecer num primeiro contato, eis que, como esclarece Gelson Amaro de Souza, o direito de ação do autor é exercido, havendo, inclusive, julgamento de mérito, o qual apenas não lhe será favorável. ${ }^{418}$

Saliente-se, ainda, que o art. 285-A do CPC não implica em limitação ao direito de ação, já que para que este se concretize não é necessário a formação da relação processual triangular entre o juiz, o autor e o réu (essa, não é demais lembrar, já não existia na hipótese de indeferimento da petição inicial, nos termos do art. 295, do CPC), tampouco está atrelado ao sucesso do pedido, em outras palavras, a uma sentença favorável. ${ }^{419}$

Percebe-se, assim, que a possibilidade de sentença liminar prevista no art. 285-A do CPC se coaduna com os escopos da terceira onda renovatória, já aventados. Nesse sentido, tal instrumento garante ao autor o acesso ao Judiciário e ao provimento jurisdicional mais adequado, num prazo de tempo razoável.

\footnotetext{
${ }^{417}$ Nesse sentido, confira-se: "O princípio do acesso à justiça, consagrado no inc. XXXV do art. $5^{\circ}, C F$, está, pois, absolutamente preservado na medida que o autor exerce o direito constitucional de propor ação e, ainda, ver seu pleito receber apreciação do Poder Judiciário, apesar de desfavorável às suas pretensões. $O$ importante, sob o aspecto constitucional, é ter o direito de ajuizar ação e receber, tempestivamente, sentença do juiz, seja ela favorável ou desfavorável”. (CERQUEIRA, Fábio Ruiz; MAIDAME, Márcio Manoel. Art. 285-A do CPC: fundamentos, importância e aplicabilidade no processo civil brasileiro. . In: ALVIM, Arruda; ARRUDA ALVIM, Eduardo. Atualidades do processo civil. Curitiba: Juruá, 2007. v. 1, p. 356. Não é outro o entendimento de Guilherme Gonçalves Strenger, ao afastar a afirmação de que a ação não teria sido exercida quando há julgamento conforme o disposto no art. 285-A do CPC. (STRENGER, Guilherme Gonçalves. A constitucionalidade nos julgamentos de mérito, sem citação. São Paulo: LTr, 2010. 64-65).

${ }^{418}$ SOUZA, Gelson Amaro de. Sentença de mérito sem a citação do réu - art. 285-A do CPC. Revista Dialética de Direito Processual, São Paulo, n. 43, p. 50, 2006.

${ }^{419}$ No mesmo sentido, Mirna Cianci destacou que: "Já restou demonstrado prefacialmente que temos ação desde que o autor invoque a jurisdição e ainda que não triangularizada a relação, ou restaria sem explicação a atividade desenvolvida nas ações indeferidas in limine sob qualquer outro fundamento, de sorte que o acesso à justiça não resulta maculado pela inovação, admitida a abstração do direito de ação. Temos, portanto, ainda quando julgada de plano improcedente a ação que tenha por objeto matéria exclusivamente de direito, como exige o dispositivo legal, mesmo que negativa ou contraria as aspirações do demandante, o que não se pode traduzir em vedação do acesso à justiça." (CIANCI, Mirna. O acesso à justiça e as reformas do CPC. São Paulo: Saraiva, 2009. p. 193. (Coleção direito e processo - Coordenador Cássio Scarpinella Bueno).
} 


\subsection{Princípio do contraditório}

Em que pese muitos estudos tenham sido feitos tendo por objeto o princípio do contraditório, o tema, ao lado do princípio da ampla defesa, ainda permanece atual e muitos de seus aspectos ainda suscitam o debate.

Enquanto a Constituição de 1824 foi silente tanto quanto ao tema contraditório, quanto à ampla defesa, a de 1891 foi a primeira a referir-se ao vocábulo defesa, sendo que a Constituição de 1934 foi além, prevendo em seu art. 113, § 24 que "A lei assegurará aos acusados ampla defesa, com os meios e recursos essenciais a esta”.

O princípio do contraditório, por sua vez, presente em inúmeros ordenamentos jurídicos ${ }^{420}$, somente ganhou alusão na Constituição Federal brasileira de 1937, em seu art. $122, \S 11$. As garantias do contraditório e da ampla defesa tiveram, em seu nascedouro, campo de aplicação circunscrito ao âmbito do processo penal. Foi a Carta Magna de 1988 que deu maior ênfase à expressão ampla defesa e estendeu o contraditório aos processos civis e administrativos. ${ }^{421}$

O contraditório é elemento integrante do conceito de processo. ${ }^{422}$ Não existe processo democrático onde não se respeita o contraditório. É um conceito não só jurídico, mas também político, podendo ser considerado resultado do postulado do Estado de Direito, pois que se trata de uma reivindicação quase intuitiva e que norteia o sentimento social. $^{423}$

\footnotetext{
${ }^{420}$ O próprio Codice di procedura civile italiano, no seu art. 101, define o princípio do contraditório (Principio del contraddittorio), quando diz expressamente: "Il giudice, salvo che la legge disponga altrimenti, non puo' statuire sopra alcuna domanda, se la parte contro la quale e' proposta non $e^{\prime}$ stata regolarmente citata e non $e^{\prime}$ comparsa". Em tradução livre: $\mathrm{O}$ juiz, salvo se a lei dispuser em contrário, não pode decidir sobre nenhuma demanda se a parte contra a qual é a mesma proposta não foi citada ou compareceu.

${ }^{421}$ Dispõe o Art. 5. ${ }^{\circ}, \mathrm{LV}$, da Constituição Federal: "aos litigantes, em processo judicial ou administrativo, e aos acusados em geral são assegurados o contraditório e a ampla defesa, com os meios e recursos a ela inerentes".

${ }^{422}$ Sobre a amplitude e exigência do contraditório no processo, confira-se lição de Luigi Paolo Comoglio: "In primo luogo, come la protezione costituzionalle della situazione dell'imputato o del convenuto non si limita alla fase di 'constituzione' del rapporto processuale, ma compreende ogni possibile attività difensiva in ciascun grado del procedimento, cosí la situazione processuale dell'attore non può considerarsi costituzionalmente tutelata com la sola possibilità di promuovere il giudizio, poiché soprattutto nel corso del processo si manifesta l'esigenza di un effettivo contraddittorio". (COMOGLIO, Luigi Paolo. La garanzia dell'azzione e il processo civile. Padova: Cedam, 1970. p. 148).

${ }^{423} \mathrm{~A}$ esse respeito, leciona Leonardo Greco: "O contraditório reveste-se, ainda, do mais elevado significado como princípio basilar do próprio Estado de Direito, porque a Democracia do nosso tempo é essencialmente participativa, ou seja, é o regime de relações entre o Estado e os cidadãos nos quais a todos os indivíduos, nos limites de seus interesses, é assegurado o direito de participação na formação da vontade estatal." (GRECO, Leonardo. O princípio do contraditório. Revista Dialética de Direito Processual, São Paulo, n. 24, p. 79, mar. 2005).
} 
Possui o contraditório um viés dialético que se expressa, dentro do processo, com a possibilidade de apresentação de uma pretensão pelo autor (tese), cuja resistência pelo réu dará ensejo à sua antítese e, por fim, com a prolação da sentença pelo juiz, culminará com a síntese. $^{424}$

É de se esclarecer que, embora interligados, o contraditório e a ampla defesa apresentam conceitos que não se confundem. O contraditório permite a isonomia de atuação entre as partes no processo, concedendo-lhes a bilateralidade de informações e manifestações, sempre ouvidas pelo juiz. A ampla defesa, por sua vez, coloca à disposição das partes - não só do réu - uma vasta possibilidade de alegações e de produção de provas como modo de permitir a disputa e o diálogo entre as partes a propiciar a sentença mais adequada e correta possível. ${ }^{425}$

A Constituição Federal ao garantir a todos os litigantes o contraditório e a ampla defesa, quer com isso dizer que tanto o direito de ação, quanto o direito de defesa são a perfeita manifestação do princípio do contraditório. Trata-se de garantia inerente a todas as partes envolvidas na lide, ou seja, uma segurança constitucional estendida às partes para que elas apresentem os seus argumentos, assim como requeiram e produzam as provas que acharem necessárias e adequadas à defesa dos seus direitos alegados.

Apesar de haver pontos de confluência entre o contraditório e a ampla defesa, Gil Ferreira de Mesquista defende a presença de dois critérios distintivos entre os mesmos, quais sejam: o dos destinatários e o do grau de dependência. Para o citado autor, o contraditório, destinado tanto ao autor quanto ao réu, possui maior alcance, em suas palavras "funcionará como um gatilho para a ampla defesa", ficando esta restrita ao réu,

\footnotetext{
${ }^{424}$ Tal pensamento encontra defensores na doutrina pátria: “O contraditório, destarte, apresenta uma dupla configuração: ele é garantia das partes, que terão a oportunidade de oferecer suas razões; e é também elemento de garantia para o juiz e para o próprio processo, na medida em que essa atuação das partes, cada uma tentando dialeticamente demonstrar a veracidade de sua própria versão, permite uma boa probabilidade de se obter a verdade real. Nessa medida, como se verá adiante, tanto numa dimensão quanto na outra o contraditório se toma instrumento de legitimação do processo: é legítimo o processo em que as partes tiveram ampla e eficaz oportunidade de atuação, como é legítima a decisão daí decorrente, porque essa atuação dialética permitirá ao juiz chegar o mais próximo possível da verdade." (BRAGHITTONI, Rogério Ives. O princípio do contraditório no processo: doutrina e prática. Rio de Janeiro: Forense Universitária, 2002. p. 16-17).

${ }^{425}$ A respeito de tais conceitos, confira-se lição de Alexandre de Moraes: "Por ampla defesa entende-se o asseguramento que é dado ao réu de condições que lhe possibilitem trazer para o processo todos os elementos tendentes a esclarecer a verdade ou mesmo de omitir-se ou calar-se, se entender necessário, enquanto o contraditório é a própria exteriorização da ampla defesa, impondo a condução dialética do processo (par conditio), pois a todo ato produzido pela acusação caberá igual direito da defesa de oporse-lhe ou de dar-lhe a versão que melhor lhe apresente, ou, ainda, de fornecer uma interpretação jurídica diversa daquela feita pelo autor". (MORAES, Alexandre de. Direito constitucional, cit., p. 95).
} 
que dela deverá valer-se para “contra-atacar tanto a pretensão do autor quanto os possíveis desmandos do órgão jurisdicional”. 426

De fato, o contraditório possui maior abrangência pois comporta não só o o direito de presença e de ser comunicado dos atos processuais praticados ou pendentes de realização, como também a possibilidade de manifestação a respeito.

Por muito tempo a doutrina resumiu o contraditório ao binômio informação-reação, isto é, faziam alusão à necessidade absoluta de dar-se conhecimento da existência às partes dos atos praticados no processo e à possibilidade de manifestação acerca deles. ${ }^{427}$

Com relação ao primeiro aspecto, referia-se à obrigatoriedade de informação precisa às partes sobre todos os atos processuais praticados no decorrer do processo, fossem eles produzidos pelo juiz ou pela parte adversa. Já no tocante ao segundo aspecto, falava-se da facultatividade de reação da parte ante a informação recebida. ${ }^{428}$

Com relação ao primeiro elemento, informação, parece não haver necessidade de maiores digressões. No tocante ao segundo elemento, reação, convém apenas destacar que daí emerge a possibilidade de produção das mais variadas formas de resistência seja por meio da apresentação de defesa, provas, etc. ${ }^{429}$

${ }^{426}$ MESQUITA, Gil Ferreira de. Princípios do contraditório e da ampla defesa no processo civil brasileiro. São Paulo: Juarez de Oliveira, 2003. p. 177-188.

${ }^{427}$ Sobre esse binômio informação (necessária) e reação (possível), trazemos a baila lição de Sergio La China: "il principio del contradditorio si articola, nelle sue manifestazioni tecniche, in due aspetti o tempi essenziali: informazione, reazione; necessaria sempre la prima, eventuale la seconda (ma necessario que sia resa possibile!)". (LA CHINA, Sergio. L'esecuzione forzata e le disposizioni generali del Codice di Procedura Civile. Milano: Giuffrè, 1970. p. 394).

${ }^{428}$ Nelson Nery Júnior teve a oportunidade de sustentar que: "por contraditório deve entender-se, de um lado, a necessidade de dar conhecimento da existência da ação e de todos os atos do processo às partes, e, de outro, a possibilidade de as partes reagirem aos atos que lhe sejam desfavoráveis. Garantir-se o contraditório significa, ainda, a realização da obrigação de noticiar (Mitteilungspflicht) e da obrigação de informar (Informationspflicht) que o órgão julgador tem, a fim de que o litigante possa exteriorizar suas manifestações. Os contendores têm direito de deduzir suas pretensões e defesas, de realizar as provas que requereram para demonstrar a existência de seu direito, em suma, direito de serem ouvidos paritariariamente no processo em todos os seus termos". (NERY JÚNIOR, Nelson. Princípios do processo na Constituição Federal: processo civil, penal e administrativo, cit., p. 206-207). Outro não é o entendimento de Ada Pellegrini Grinover, Antonio Carlos de Araújo Cintra e Cândido Rangel Dinamarco, para os quais o contraditório é definido como sendo constituído por dois elementos: " $a$ ) informação; $b$ ) reação (esta, meramente possibilitada nos casos de direitos disponíveis)". (CINTRA, Antônio Carlos de Araújo; DINAMARCO, Cândido Rangel; GRINOVER, Ada Pellegrini. Teoria geral do processo, cit., p. 55).

${ }^{429}$ Sobre esse segundo aspecto do contraditório, destacamos o entendimento de Antonio do Passo Cabral: "Ligado à ciência dos atos está o segundo pala que compõe o núcleo essencial do princípio, a garantia de expressão ou de reação no processo (Recht auj Ausserung). As partes têm direito de manifestar-se sobre os elementos fáticos e jurídicos contidos nos autos, sendo-lhes facultadas as vias oral e escrita através de seus advogados, ou mesmo pessoalmente, quando dispensada a capacidade postulatória. E, se por um lado é imperativa a informação aos interessados, sua reação é apenas possível, visto que, em homenagem à liberdade das partes, não se pode impor o exercício de um direito como o contraditório. Pense-se no exemplo da revelia, em que o réu, apesar de citado (e portanto informado do ajuizamento da demanda), 
Contudo, o contraditório não pode mais ser entendido em seu aspecto estático, como o simples direito de ser ouvido pelo juiz ou o direito à bilateralidade da audiência. No contexto atual, o contraditório deve ser entendido tendo por base três elementos: direito à informação necessária, possibilidade da reação à pretensão deduzida e direito ao diálogo pertinente, isto é, à participação. ${ }^{430}$

Em sua aplicação, busca-se garantir uma maior justiça nas decisões, uma vez que confere às partes a faculdade de participação no processo e, conseqüentemente, na formação do convencimento do juiz. ${ }^{431}$

Ao jurista italiano Elio Fazzalari atribui-se a diferenciação entre procedimento e processo, este último marcado pela presença do contraditório. Para este, o processo, como procedimento em contraditório, demanda que todos aqueles que suportarão o resultado do provimento participem de forma paritária para a formação do mesmo. Com efeito, referido autor constata a existência na estrutura do contraditório dos seguintes elementos: (1) participação dos destinatários do ato final na fase preparatória do mesmo; (2) simétrica paridade desses interessados; (3) mútua implicação de seus atos; (4) relevância de tais atos para o ato final. ${ }^{432}$

A concepção clássica de processo baseada na relação jurídica processual e essa apresentada por Fazzarali de processo como procedimento em contraditório não se excluem mas, ao contrário, se complementam. ${ }^{433}$

O contraditório passa da dimensão meramente formal, que garante a todos o direito de participar de um processo que lhes diga respeito, para ter também uma dimensão

não oferece contestação." (CABRAL, Antonio do Passo. Contradiório. In: TORRES, Ricardo Lobo; KATAOBA, Eduardo Takemi; GALDINO, Flavio (Org.). Dicionário de princípios jurídicos. Rio de Janeiro: Elsevier, 2011. p. 196).

${ }^{430}$ Cf. LOPES, Maria Elizabeth de Castro. Princípio do contraditório. In: OLIVEIRA NETO, Olavo de; LOPES, Maria Elizabeth de Castro (Orgs.). Princípios processuais civis na Constituição. Rio de Janeiro: Elsevier Campus, 2008. p. 106.

${ }^{431}$ Elucidativo do caminho a ser trilhado, realçando o terceiro elemento (participação), confira-se lição de Antonio do Passo Cabral: "A decisão deve expressar a melhor resolução do litígio, acolhendo ou refutando os argumentos constantes dos autos e as manifestações dos sujeitos processuais e o ato decisório têm de estampar de forma cristalina a síntese das contribuições colhidas pelo exercício do contraditório, ainda que seja para afastar os argumentos e elementos irrelevantes ou equivocados para a solução da lide. Nesse contexto, a concepção do contraditório como direito de influência justifica-se na moldura de democracia participativa e deliberativa. Com efeito, dentre os escopos políticos do processo destaca-se a missão de permitir a participação do indivíduo na vida política do país. Trata-se de peculiar espectro da condição de cidadão, o 'status ativus processualis', que consubstancia o direito fundamental de participação ativa nos procedimentos estatais decisórios, ou seja, direito de influir na formação de normas jurídicas vinculativas." (CABRAL, Antonio do Passo. Contradiório, cit., p. 200).

${ }^{432}$ FAZZALARI, Elio. Istituzioni di diritto processuale. 8. ed. Padova: CEDAM, 1996. p. 82.

${ }^{433} \mathrm{Cf}$. BRAGHITTONI, Rogério Ives. O princípio do contraditório no processo: doutrina e prática, cit. 
substancial, qual seja, o poder de se manifestar e, através da participação e do debate, influenciar o conteúdo da decisão. ${ }^{434}$

A esse respeito, destacamos voto do Ministro Gilmar Mendes, proferido nos autos do Mandado de Segurança 24268, em que destaca que o princípio do contraditório, assegurado pela Constituição, não se limita à garantia de arguição oportuna e eficaz a respeito de fatos, mas sugere a possibilidade de ser ouvido também em matéria jurídica. ${ }^{435}$

O tema em questão também foi alvo de reflexão no direito português, concluindo José Manuel Lebre de Freitas ter sido de importância fundamental para aquele ordenamento a compreensão de que " a contrariedade não consiste só na contraposição de requerimento e resposta, mas, de modo mais geral, na concessão às partes, ao longo de todo o processo, de todos os meios de actuação legítima susceptíveis de exercer influência na decisão do litígio."

Importa frisar que a doutrina, atenta às necessidades do direito processual moderno, tem entendido que há situações em que, a fim de não comprometer a efetividade da prestação jurisdicional, é possível a remoção do contraditório para um outro momento do curso procedimental. Isto porque, não há qualquer menção na Carta Magna quanto ao momento de incidência do contraditório. Assim, sem que o contraditório seja eliminado, posterga-se a aplicação da garantia para um instante sucessivo do provimento, para não inutilizar a sua eficácia. Trata-se do chamado contraditório diferido. ${ }^{437}$

Conclui-se de tudo que foi exposto que o contraditório deve ser interpretado atualmente como mecanismo que assegure às partes ao máximo sua participação no curso

\footnotetext{
${ }^{434}$ Como bem observa Antonio do Passo Cabral, essa nova dimensão do contraditório faz com que se afastem as "chagas individualistas" que tanto prejudicam a compreensão do princípio e possibilitam a admissão de diferentes entidades no processo, a fim de estimular o diálogo e "oxigenar o litígio com outros pontos de vista argumentativos”. (CABRAL, Antonio do Passo. Contradiório, cit., p. 201).

${ }^{435}$ Assinala, assim, que no art. 5 $5^{\circ}, \mathrm{LV}$, da Constituição, vislumbram-se os seguintes direitos: “1) direito de informação (Recht auf Information), que obriga o órgão julgador a informar à parte contrária dos atos praticados no processo e sobre os elementos dele constantes; 2) direito de manifestação (Recht auf Äusserung), que assegura ao defendente a possibilidade de manifestar-se oralmente ou por escrito sobre os elementos fáticos e jurídicos constantes do processo; 3) direito de ver seus argumentos considerados (Recht auf Berücksichtigung), que exige do julgador capacidade, apreensão e isenção de ânimo (Aufnahmefähigkeit und Aufnahmebereitschaft) para contemplar as razões apresentadas (Cf.Pieroth e Schlink, Grundrechte -Staatsrecht II, Heidelberg, 1988, p. 281; Battis e Gusy, Einführung in das Staatsrecht, Heidelberg, 1991, p. 363-364; Ver, também, Dürig/Assmann, in: Maunz-Dürig, GrundgesetzKommentar, Art. 103, vol IV, no 85-99)”. (MS 24268, Relator(a): Min. ELLEN GRACIE, Relator(a) p/ Acórdão: Min. GILMAR MENDES, Tribunal Pleno, julgado em 05/02/2004, DJ 17-09-2004 PP-00053 EMENT VOL-02164-01 PP-00154 RDDP n. 23, 2005, p. 133-151 RTJ VOL-00191-03 PP-00922).

${ }^{436}$ FREITAS, José Manuel Lebre de. A exigência de celeridade e os princípios processuais (a experiência portuguesa). Revista da Faculdade de Direito do Sul de Minas, Pouso Alegre, v. 26, n. 2, p. 186, jul./dez. 2010.

${ }^{437}$ Cf. LOPES, Maria Elizabeth de Castro. Princípio do contraditório, cit., p. 107.
} 
do processo e possibilite, em igualdade de condições, influenciar no convencimento do magistrado, que terá assim possibilidade de atingir uma decisão mais justa e legítima.

Há, ainda, situações excepcionais previstas em lei em que se admite seja o contraditório adiado, sem que ocorra ofensa ao preceito fundamental. Para tanto, admite-se que algumas fases do procedimento sejam suprimidas ou que haja sua centralização em um só momento, por ser tal posicionamento mais benéfico, prestigiando-se outros valores também importantes como a celeridade e economia processual.

Feito esse breve apanhado sobre o princípio do contraditório, cumpre verificar a existência ou não de afronta ao mesmo nos casos de julgamento liminar de improcedência, sem citação do réu, utilizando-se do permissivo do art. 285-A, do CPC.

Parcela da doutrina sustenta a inconstitucionalidade da norma por suposta violação ao princípio do contraditório. ${ }^{438}$

Defende-se a inconstitucionalidade do artigo, argumentando que o art. 285-A implica restrição ao direito de se constituir um diálogo entre os sujeitos do processo e, mais, de influenciar na formação do convencimento do magistrado. ${ }^{439}$

Contudo, este posicionamento não parece ser o mais adequado à solução da questão que ora se analisa. Senão vejamos.

Após a prolação de sentença com fundamento no art. 285-A, do CPC, três situações podem advir: a) o autor, inconformado, interpõe apelação, e o juiz se retrata da decisão, na forma do $\S 1^{\mathrm{o}}$; b) o autor, inconformado, apela e o juiz não se retrata, mantendo a sua decisão, nos termo do $\S 2^{\circ}$; c) o autor se conforma com a sentença de $1^{\circ}$ grau, deixando fluir integralmente o prazo, sem interpor recurso.

Nos dois primeiros casos, não há como sustentar ofensa ao contraditório, pois, em ambos, haverá a citação do réu.

Na primeira situação, prescreve o $\S 1^{\circ}$ : “Se o autor apelar, é facultado ao juiz decidir, no prazo de cinco (5) dias, não manter a sentença e determinar o prosseguimento da ação”. Assim, caso o autor apele e o juiz opte pela retratação, determinará o normal

\footnotetext{
${ }^{438}$ Nesse sentido: MEDINA, Paulo Roberto de Gouvêa. Sentença emprestada: uma nova figura processual, cit., p. 155, 2006 e MITIDIERO, Daniel. A multifuncionalidade do direito fundamental ao contraditório e a improcedência liminar (art. 285-A, CPC): resposta à crítica de José Tesheiner. Revista de Processo, São Paulo, v. 32 n. 144, p. 109-110, fev. 2007.

${ }^{439}$ Cf. GONÇALVES, Helena de Toledo Coelho. Contraditório e ampla defesa, cit., p. 81.
} 
seguimento do feito, devendo o réu ser citado para apresentar resposta, como se não houvesse aplicação do art. 285-A.

Dispõe o $\S 2^{\circ}$ do artigo 285-A do CPC, por sua vez, que caso o magistrado opte por manter sua sentença, deverá o réu ser citado para que possa responder ao recurso do autor. Nesse sentido, havendo a citação do réu, o contraditório também estará assegurado. ${ }^{440}$

O contraditório, como se percebe, não foi abandonado pelo juiz da causa, mas diferido para momento posterior. Somente poderia cogitar-se em desrespeito ao contraditório caso o juiz proferisse julgamento de procedência ou parcial procedência da ação sem a participação do réu no processo. ${ }^{441}$

Com efeito, trata-se de situação, prevista na própria lei, em que tal princípio recebe limitação, levando-se em conta que a dispensa prévia da citação da parte demandada, para fins de apresentar resposta, não lhe causaria nenhum prejuízo, quer processual quer material. Em outros dizeres, o contraditório não fez falta ou, no mínimo, seria medida vazia na hipótese, diante da posição benéfica do réu. ${ }^{442}$

A problemática parece já ter sido superada pela doutrina e pela jurisprudência, nas discussões travadas nos casos de antecipação dos efeitos da tutela e da concessão de medida liminar, sem a audiência da parte adversa, oportunidade em que se justificou sua prática a fim de garantir efetividade da atividade jurisdicional.

\footnotetext{
${ }^{440}$ Cf. BONDIOLI, Luís Guilherme Aidar. O julgamento liminar de improcedência da demanda da óptica do réu (art. 285-A do CPC), cit., p. 16. Do mesmo sentir: CAVALCANTE, Mantovanni Colares. A sentença liminar de mérito do art. 285-A do Código de Processo Civil e suas restrições, cit., p. 98-99.

${ }^{441}$ Salientamos, por oportuno, o excelente trabalho desenvolvido por Ruy Fernando Zoch Rodrigues em sua tese de doutorado que, a par da impossibilidade de uma sentença de procedência prima facie, promove o estudo da possibilidade de antecipação, total ou parcial, de efeitos práticos do pedido formulado pelo autor, tendo por base apenas a evidência do direito, oriunda das anteriores demandas repetitivas. Referido autor, após longo estudo, conclui ser possível a antecipação da tutela de direito evidente em ações repetitivas, inclusive sem a oitiva da parte contrária e sem necessidade do requisito da urgência, porém, se aproveitando dos mesmos mecanismos de efetivação utilizados para as medidas urgentes. (RODRIGUES, Ruy Fernando Zoch. Antecipação de tutela sem o requisito da urgência em ações repetitivas. 2009. Tese (Doutorado) - Faculdade de Direito, Universidade de São Paulo, São Paulo, 2009).

${ }^{442}$ O professor Flávio Luiz Yarshell traz passagem bem elucidativa em que abona tal afirmativa: "Conquanto a constitucionalidade do dispositivo tenha sido posta em dúvida, não parece lícito afirmar que decisão dessa ordem seja, só por dispensar o contraditório, ilegítima ou injusta. Assim ocorre na medida em que, decretada a total improcedência da demanda, nenhum resultado juridicamente superior poderia o réu (na demanda) obter, por mais e melhores argumentos que pudesse trazer ao órgão judicial. Portanto, sua participação se torna desnecessária, porque, embora o contraditório até funcione como fator de aprimoramento dos atos de poder, o que verdadeiramente determina a observância da garantia é a aptidão do ato de desvincular desfavoravelmente alguém. Pensar diferentemente - isto é, levar às últimas consequências a ideia de contraditório como forma de aperfeiçoamento de decisões judiciais - seria supor que realmente o dispositivo seria inconstitucional”. (YARSHELL, Flávio Luiz. Antecipação da prova sem o requisito da urgência e direito autônomo à prova. São Paulo: Malheiros Ed., 2009. p. 167).
} 
Questão mais complexa se afigura na terceira situação, já que, inexistindo recurso, não será o réu citado, e, ainda assim, a sentença transitará em julgado, operando todos os seus efeitos. Todavia, ainda aqui não vislumbramos qualquer ofensa ao contraditório. Isto porque um dos maiores vetores do princípio do contraditório é o amparo da parte processual. Se a sentença judicial, em tese, não tem aptidão de causar prejuízo ao réu, não haveria necessidade de a este ser assegurado o direito de contribuir para a formação do convencimento do julgador, que, repita-se, já lhe é favorável. ${ }^{443}$

De fato, o art. 285-A do CPC não fere a garantia constitucional do contraditório uma vez que a sentença revela-se favorável ao réu. Nesse sentido, não há que se falar em determinação de citação se a sentença será de improcedência. Inexiste interesse em se chamar o réu a juízo uma vez que não haverá nada do que se defender.

Nesse contexto, confira-se lição de Flávio Luiz Yarshell:

Se a demanda é desde logo julgada improcedente, parece lícito presumir que nenhuma ordem de restrição ou prejuízo se impôs ao réu que, portanto, só se pode entender beneficiado pelo indeferimento; como, aliás, ocorre nas hipóteses em que, também em seu favor, pronuncia-se a prescrição ou a decadência. Portanto, na hipótese aventada, não há violação ao contraditório porque a participação do réu, em princípio, não o levará a situação mais vantajosa do que aquela que estabeleceu a sentença. $^{444}$

O artigo 285-A, ainda, não inibe a participação das partes por aplicar ao caso concreto outro decisum, anteriormente proferido, para o qual a parte não influiu. ${ }^{445}$

\footnotetext{
${ }^{443}$ Do mesmo sentir, vale destacar o posicionamento de Gelson Amaro de Souza acerca do assunto: "Princípios basilares do processo como o contraditório, a ampla defesa e o devido procedimento legal foram instituídos em benefício da parte para evitar que ela sofra prejuízo. No entanto, se nenhum prejuízo advier à parte, nada há a reclamar. É o que acontece quando o mérito é julgado a favor do réu, em que a sua citação em nada importa e mesmo desta não o prejudique. A ausência da citação nenhum prejuízo traz ao réu (art. 249, parágrafo $2^{\circ}$, do CPC). Exigir-se o atendimento do contraditório quando a sua presença em nada altera o resultado final e a sua ausência em nada prejudica a parte é dar mais valor à forma que ao direito. É andar na contramão da moderna processualística”. (SOUZA, Gelson Amaro de. Sentença de mérito sem a citação do réu - art. 285-A do CPC, cit., p. 51).

${ }^{444}$ Cf. YARSHELL, Flávio Luiz. Indeferimento da inicial e improcedência da demanda? Carta Forense. Disponível em: <http://www.cartaforense.com.br/conteudo/colunas/indeferimento-da-inicial-eimprocedencia-da-demanda/60>. Acesso em: 25 out. 2012.

445“"O art. 285-A do CPC exige que mais de uma causa tenha sido analisada, de maneira minuciosa em seus elementos objetivos e o Poder Judiciário, pelos Tribunais Superiores e pelo STF, tenham definido jurisprudência dominante ou sumulada. O contraditório, portanto, teria sido exercido, de forma participativa, por vários sujeitos, para a obtenção de uma sentença de improcedência. Por isso, falsa é a ideia de que não teria havido contraditório. Muito pelo contrário. Houve grande participação, anterior, para se chegar à conclusão jurisprudencial que autoriza o indeferimento imediato da petição inicial." (STRENGER, Guilherme Gonçalves. A constitucionalidade nos julgamentos de mérito, sem citação. São Paulo: LTr, 2010. p. 69).
} 
Em que pese os estudos sobre o princípio do contraditório façam referência à necessidade de participação da parte no processo para, inclusive, poder influenciar, legitimamente, a convicção do juiz, temos para nós que o anseio da parte em influir no convencimento do magistrado é precisamente para obter para si um resultado favorável no processo. Ocorre, contudo, que esse resultado ocorreu mesmo diante da ausência da parte no processo, não havendo que se suscitar qualquer nulidade, por carência de prejuízo ao réu.

Não há, portanto, por qualquer ângulo que se analise a questão, inconstitucionalidade no art. 285-A, do CPC, por agressão às exigências do contraditório e da ampla defesa. A sentença liminar de improcedência além de não violar o contraditório, defende os valores da celeridade processual e permite a racionalização do julgamento das demandas repetitivas.

\subsection{Princípio do devido processo legal}

A cláusula do due processo of law (traduzida pela doutrina brasileira como devido processo legal), originou-se do direito inglês. A noção, não a terminologia due process of law, advém do artigo 39 da Magna Carta inglesa de João Sem Terra, no ano de 1215, sob a terminologia de legem terrae, termo posteriormente traduzido para a língua inglesa como law of the land. ${ }^{446}$

Referida lei, é bom salientar, surgiu como instrumento protetor dos direitos e liberdades dos nobres e proprietários de glebas contra os excessos e tiranias da coroa inglesa, servindo, assim, de mecanismo de resistência ao poder do monarca, que somente poderia avançar sobre seus bens desde que observado os parâmetros estabelecidos em lei.

Foi somente no ano de 1354, durante o reinado de Eduardo III, que o Parlamento inglês editou o conhecido "statute of Westminster of the Liberties of London”, substituindo

\footnotetext{
${ }^{446}$ Sobre a Magna Carta Libertatum, destacamos, a título de curiosidade, relato de Yoshikawa: “o documento, escrito em latim e com mais de sessenta artigos, dispunha sobre diversos assuntos (administração da justiça, liberdades pessoais, tributação, separação entre Estado e Igreja e outros que hoje têm apenas interesse histórico), estabelecendo princípios que subsistem até os dias de hoje, o que explica o duradouro prestígio da Magna Carta depois de oito séculos, apesar de a maior parte de seus dispositivos se encontrar revogada". (YOSHIKAWA, Eduardo Henrique de Oliveira. Execução extrajudicial e devido processo legal. São Paulo: Atlas, 2010. p. 45-46).
} 
a expressão per legem terrae pela hoje conhecida due processo of law, estendendo-se as garantias da Carta Magna para todas as pessoas do reino. ${ }^{447}$

Os Estados Unidos da América, que sofreu forte influência do direito inglês, não tratou originalmente do instituto na sua Constituição Federal de 1787, o que só veio ocorrer de forma expressa com a $5^{\mathrm{a}}$ emenda à Constituição realizada em 1791, surgindo ao lado do trinômio "vida, liberdade e propriedade". ${ }^{448}$

A $14^{\mathrm{a}}$ emenda à Constituição americana, no ano de 1868, pode ser destacada no processo evolutivo do devido processo legal daquele sistema, pela nova amplitude que deu à clausula ao garantir igualdade na lei e não só "perante a lei”, promovendo a proteção de direitos fundamentais contra ações arbitrárias. ${ }^{449}$

Ressalte-se, também, que referido princípio constou implicitamente do artigo 18 da Carta Argentina de 1853 e, no México, do artigo 14 da Constituição de $1857 .{ }^{450}$

\footnotetext{
${ }^{447}$ Acerca dessa passagem histórica no direito inglês, trazemos a baila lição de Arruda Alvim: "A Magna Carta, do ano de 1215, de João Sem Terra, exerceu função limitadora do poder real e não do Parlamento, propriamente dito. Foi considerada como monumento das liberdades inglesas; hoje, é tida, todavia, como tendo sido representativa de uma auto-limitação real, de não infração de privilégios dos barões, ainda que esses privilégios não fossem compatíveis com os de outros súditos (ou, com a ausência de tais privilégios), o que é um indicativo de que nela se ostentava, apenas palidamente, a noção ou idéia de democracia (é o que observa Rodney L. Mott, Due Process of Law, 1926, p. 4, ao lado de diversos outros autores, no mesmo sentido). Falava-se na Magna Carta em "per legem terrae" ou "law of the land", significando-se com isto regras emergentes, que marcaram profundamente, sem maior solução de continuidade histórica, a evolução do direito inglês. Em 1354 são tais expressões substituídas pela cláusula do "due process of law", cuja substituição foi precedida de episódio digno de nota (O Conde Arundell se insurgiu contra a prisão de seu pai, sem julgamento e de forma ilegal)". (ALVIM, Arruda. Princípios constitucionais na Constituição Federal de 1988 e o acesso à justiça, cit., p. 15).

${ }^{448}$ Assim dispõe a $5^{\circ}$ emenda à Constituição americana: "No person (...) shall be compelled in any criminal case to be a witness against himself, nor be deprived of life, liberty, or property, without due process of law (...)." Em tradução livre: "Ninguém será obrigado em qualquer processo criminal a servir de testemunha contra si mesmo; nem ser privado da vida, liberdade, ou bens, sem o devido processo legal".

${ }^{449}$ Com propriedade, sobre a origem histórica do instituto no direito americano, Patrícia Mothé Glioche anota: "Nos Estados Unidos, com a Guerra da Independência, em 1776, e a Constituição Americana de 1787 foi implantado o federalismo e, na busca de um controle legal dos indivíduos contra o governo nacional, foi instituído o Bill of Rights, sendo que na $5^{a}$ Emenda da Constituição norte-americana foi abraçado o princípio do devido processo legal, posteriormente também mencionado na sua $14^{a}$ Emenda. Desse modo, nos Estados Unidos, onde há tradicionalmente a descentralização do poder, em razão da estrutura própria do federalismo, o princípio do devido processo legal foi ampliado para proteger o povo em relação também às leis e Constituições Estaduais". (BÉZE, Patrícia Mothé Glioche. Devido processo legal. In: TORRES, Ricardo Lobo; KATAOBA, Eduardo Takemi; GALDINO, Flavio (Org.). Dicionário de princípios jurídicos. Rio de Janeiro: Elsevier, 2011. p. 246).

${ }^{450}$ Cf. DIAS, Jefferson Aparecido. Princípio do devido processo legal. In: OLIVEIRA NETO, Olavo de; LOPES, Maria Elizabeth de Castro (Orgs.). Princípios processuais civis na Constituição. Rio de Janeiro: Elsevier Campus, 2008. p. 28. Gil Ferreira de Mesquita aponta, ainda, a presença do princípio em comento em outros ordenamentos, dentre os quais destacamos o direito alemão, direito espanhol, direito peruano, direito japonês, entre outros. (MESQUITA, Gil Ferreira de. Princípios do contraditório e da ampla defesa no processo civil brasileiro, cit., p. 21-33).
} 
A ideia sobre o devido processo legal e seu espectro de alcance foi se ampliando e ingressou, em 1948, na Declaração dos Direitos do Homem (art. 10), e em 1966, no Pacto Internacional dos Direitos Civis e Políticos (art. $9^{\circ}$ ).

No constitucionalismo brasileiro, por sua vez, iniciado pela constituição imperial de 1824, a cláusula do devido processo legal, como cláusula autônoma, somente veio ao texto constitucional em 1988, em que pese já fosse vista como cláusula implícita em outros textos, pela consignação dos princípios da ampla defesa, do contraditório e da igualdade. ${ }^{451}$

Tal princípio pode ser considerado uma síntese das aspirações constitucionais no que se refere ao direito processual, de sorte que todos os princípios representariam seu desdobramento. É o que se denomina de cláusula geral, ou seja, toda norma principiológica cujo conteúdo é aberto, não é definido pelo texto normativo, permite que se extraiam outras normas, sendo preenchida historicamente. ${ }^{452}$

O devido processo legal é ferramenta imprescindível à manutenção dos direitos e garantias fundamentais num Estado democrático. Trata-se de cláusula protetiva das liberdades públicas, contra os excessos praticados por autoridades legislativas, judiciárias e administrativas. ${ }^{453}$

O devido processo legal não tem uma definição fixa, perene. Com efeito, o conceito sofreu modificações através dos tempos, sendo que a doutrina e a jurisprudência alargaram o âmbito de sua abrangência.

É importante observar que analisando o processo evolutivo do devido processo legal constatamos que nos primórdios de sua criação, o princípio possuía uma acepção meramente formal. Desse modo, inicialmente, os processualistas entendiam como

${ }^{451} \mathrm{O}$ princípio do devido processo legal encontra-se expressamente consagrado na Constituição Federal brasileira, em seu artigo $5^{\circ}$, inciso LIV, com a seguinte redação: "ninguém será privado da liberdade ou de seus bens sem o devido processo legal."

${ }^{452}$ Comoglio afirma que a cláusula é uma proposição com elementos necessariamente em branco, cuja determinação destina a variar de acordo com as condições históricas, políticas, econômicas e sociais próprias do momento de sua aplicação. Em suas palavras: "La clause è dunque una proposizione con elementi necessariamente in bianco, la cui determinazione è destinata a variare con il variare delle condizioni storico-politiche ed economico-sociali, proprie del momento della sua applicazione." (COMOGLIO, Luigi Paolo. La garanzia constituzionale dell'azione ed il processo civile. Padova: Cedam, 1970. p. 128).

${ }^{453}$ Nesse diapasão, destaca-se que: “Os princípios processuais, e, especialmente, a cláusula do "devido processo legal" supõem uma moldura do Estado, que é, por excelência, a do Estado democrático, onde inúmeras garantias são asseguradas aos cidadãos. Tais princípios, em verdade, gravitam em torno da cláusula do "devido processo legal". O "devido processo legal" tem profunda expressão constitucionalprocessual, e, ademais disto, patrimonial e tributária. O que pode dizer é que a sua expressão processual (constitucional) é um reflexo das garantias constitucionais-materiais outorgadas aos cidadãos." (ALVIM, Arruda. Princípios constitucionais na Constituição Federal de 1988 e o acesso à justiça. Revista do Advogado, São Paulo, n. 34, p. 14, jul. 1991). 
cumprido o due process of law quando fosse cumprido o devido processo legal formal, isto é, quando cumprido o procedimento.

Posteriormente, passou-se a entender que tanto o tratamento impróprio das regras processuais, como também, e na mesma proporção, a existência de normas de sentido questionável, distanciadas da razoabilidade, acarretariam efeitos negativos para o processo. ${ }^{454}$ Aponta-se, assim, a existência de duas dimensões de devido processo legal, quais sejam, material (o substantive due process) e formal (procedural due process). ${ }^{455}$

O devido processo adjetivo ou procedimental é considerado mais restrito que o devido processo material e caracteriza-se pelo conjunto de garantias processuais que tornam a decisão legítima. Transcorre da ideia de que para o alcance do fim do processo, isto é, prolação de uma decisão por uma autoridade estatal, seja ela no âmbito administrativo ou judicial, é necessário que todos possuam conhecimento prévio do caminho a ser percorrido. ${ }^{456}$

Diz respeito, assim, à exigência de ordenação e regularidade legal de processos e procedimentos, judiciais e administrativos. Constitui garantia de acesso à justiça e, ainda, de obediência aos caminhos do rito legal previamente estipulado para que o Estado possa extrair de qualquer cidadão alguma liberdade conquistada.

Já em sua dimensão material ou substancial passa-se a uma análise não só da forma, mas da substância. Trata-se de um limite ao conteúdo das decisões, para que não se afastem de um sentido razoável ou do justo, a fim de tutelar o direito material do cidadão, inibindo sua ofensa por lei em sentido genérico ou ato administrativo desarrazoado.

\footnotetext{
${ }^{454}$ Cf. MEDEIROS, Luiz Cézar. Princípio do devido processo legal: procedural due process e substantive due process. In: CRUZ, Paulo Márcio; GOMES, Rogério Zuel et al. Princípios constitucionais e direitos fundamentais: contribuições ao debate. Curitiba: Juruá, 2007. p. 73.

${ }^{455}$ Acerca da coexistência no devido processo legal de dois sentidos (processual e material), esclarece Nelson Nery Junior: "A cláusula due process of law não indica somente a tutela processual, como à primeira vista pode parecer ao intérprete menos avisado. Tem sentido genérico, como já vimos, e sua caracterização se dá de forma bipartida, pois há o substantive due process e o procedural due process, para indicar a incidência do princípio em seu aspecto substancial, vale dizer, atuando no que respeita ao direito material, $e$, de outro lado, a tutela daqueles direitos por meio do processo judicial ou administrativo". (NERY JÚNIOR, Nelson. Princípios do processo na Constituição Federal: processo civil, penal e administrativo, cit., p. 81). Como bem ressalta Eduardo Henrique de Oliveira Yoshikawa "o devido processo legal controla se e em que medida alguém pode ser privado da sua vida, liberdade ou propriedade (substantive due process) e, se puder, determina que um processo seja empregado para que ocorra tal privação (procedural due process), vedando, em qualquer das hipóteses, escolhas arbitrárias e desarrazoadas por parte do legislador (quanto à privação e quanto ao processo)". (YOSHIKAWA, Eduardo Henrique de Oliveira. Execução extrajudicial e devido processo legal, cit., p. 79).

${ }^{456}$ Cf. BÉZE, Patrícia Mothé Glioche. Devido processo legal, cit., p. 246.
} 
Por esse aspecto, o devido processo legal manifesta-se em todos os ramos do direito, e mesmo fora dele, estando já consolidadas as noções de devido processo administrativo.

Ainda sobre o conteúdo material do devido processo legal, ensina José Cretella Neto que:

\begin{abstract}
"Esse caráter substantivo do devido processo legal implica que, no Estado de Direito, a elaboração da lei deve obedecer a critérios que atendam ao senso de Justiça e aos preceitos constitucionais de aplicação da norma pelo Poder Judiciário, possibilitada pela via do processo. De um lado, o Estado enuncia o Direito por meio de ato normativo geral e vinculativo; de outro, cabe-lhe solucionar as controvérsias geradas pelas normas que promulga, ou pela diversidade de interpretação delas. É precisamente a conjugação desses fatores - a lei elaborada de forma regular, correta e razoável, e sua aplicação por um Poder Judiciário independente, utilizando mecanismo em que as partes são colocadas em pé de igualdade quanto às oportunidades que lhes são oferecidas (ampla defesa, contraditório, juiz natural) - que remete ao conceito de processo justo". ${ }^{457}$
\end{abstract}

Paulo Friedrich Wilhelm Löwenthal, após estudar a aplicação do devido processo legal, no que tange à sua faceta substancial, pela Suprema Corte americana, constata que o conceito sofreu diversas alterações ao longo do tempo, passando por arrimo da liberdade contratual e, ostentando, nos dias de hoje, o papel de um plausível meio de defesa de liberdades das mais diversas ordens. ${ }^{458}$

Entende-se por esta face do devido processo legal que nenhum direito pode ser tolhido sem motivo razoável, independentemente de ter-se utilizado do procedimento adequado para tanto. A cláusula do devido processo legal, em seu conteúdo substantativo, representa, assim, um "mecanismo de controle axiológico da atuação do Estado e de seus agentes", bem como do "mérito dos atos normativos". 459

Essa ideia é bastante significativa porque fez expandir, principalmente no direito norte-americano, a atuação e o poder judicial por dois motivos: primeiro, deu às cortes poder discricionário para decidir quais direitos deveriam ser tutelados e a extensão de tal

\footnotetext{
${ }^{457}$ Cf. CRETELLA NETO, José. Fundamentos principiológicos do processo civil. Rio de Janeiro: Forense, 2002. p. 42.

${ }^{458}$ LÖWENTHAL, Paulo Friedrich Wilhelm. As origens do devido processo legal substancial e o seu desenvolvimento na Suprema Corte norte-americana. Revista de Direito Constitucional e Internacional, v. 19, n. 75, p. 306, abr./ jun. 2011.

${ }^{459}$ CASTRO, Carlos Roberto Siqueira. O devido processo legal e os princípios da razoabilidade e da proporcionalidade. Rio de Janeiro: Forense, 2010. p. 40.
} 
proteção. Ademais, uma vez que a corte decide quais direitos devem ser protegidos, pelo devido processo legal material, há possibilidade de se usar o poder judicial de revisão para forçar sua consecução, revisando toda a legislação para incorporar direitos. ${ }^{460}$

No Brasil, em que por muito tempo a terminologia devido processo legal foi usada somente no sentido processual, já há manifestações a confirmar a postura substantiva do princípio, apresentando-o como norteador da devida aplicação das normas aos casos concretos. $^{461}$

Destacamos, quanto aos aspectos substancial e formal do devido processo legal, o seguinte trecho elucidativo do voto do relator Ministro Carlos Velloso, na liminar concedida na ADIn n. 1.511-7-DF:

\begin{abstract}
“"Due process of law", com conteúdo substantivo - "substantive due process" - constitui limite ao Legislativo, no sentido de que as leis devem ser elaboradas com justiça, devem ser dotadas de razoabilidade ("reasonableness") e de racionalidade ("rationality"), devem guardar, segundo W. Holmes, um real e substancial nexo com o objetivo que se quer atingir. Paralelamente, "due process of law", com caráter processual - "procedural due process" - garante às pessoas um procedimento judicial justo, com direito de defesa". ${ }^{462}$ (grifos presentes no original)
\end{abstract}

O princípio do devido processo legal, em sua dimensão material, refere-se ao controle da regularidade do conteúdo da norma, impedindo a existência de leis arbitrárias e zelando para que estejam em harmonia com os preceitos constitucionais, bem como diz respeito à sua devida aplicação ao caso concreto, com base em reflexões acerca de razoabilidade e proporcionalidade, tornando-se um instrumento de amparo dos direitos individuais e liberdades públicas.

\footnotetext{
${ }^{460}$ Cf. DIAS, Jefferson Aparecido. Princípio do devido processo legal, cit., p. 25-46, p. 38.

${ }^{461}$ A esse respeito, destacamos lição de Oreste Nestor de Souza Laspro para o qual "o devido processo legal deixa de ser apenas formal - porque garante a obediência de certos princípios procedimentais - para ser material -, enquanto ampara os direitos subjetivos negados, violados ou ameaçados em sua essência e torna efetiva a tutela jurisdicional". (LASPRO, Oreste Nestor de Souza. Devido processo legal e a irreversibilidade da antecipação dos efeitos da tutela jurisdicional. In: MARINONI, Luiz Guilherme (Coord.). Estudos de direito processual civil: homenagem ao professor Egas Dirceu Moniz de Aragão. São Paulo: Ed. Revista dos Tribunais, 2005. p. 265-275, p. 268). Ainda neste sentido "Por não estar sujeito a conceituações apriorísticas, o devido processo legal revela-se na sua aplicação casuística, de acordo com o método de "inclusão" e "exclusão" característico do case system norte-americano, cuja projeção já se vê na experiência jurisprudencial pátria. Significa verificar in concreto se determinado ato normativo ou decisão administrativa ou judicial está em consonância com o devido processo legal”. (LUCON, Paulo Henrique dos Santos. Devido processo legal substancial. Disponível em: <http://www.revistadoutrina.trf4.jus.br/index.htm?http://www.revistadoutrina.trf4.jus.br/artigos/edicao015/ paulo_lucon.htm>. Acesso em: 25 out. 2012).

${ }^{462}$ ADI 1511 MC, Relator(a): Min. CARLOS VELLOSO, Tribunal Pleno, julgado em 16/10/1996, DJ 06-062003 PP-00029 EMENT VOL-02113-01 PP-00071.
} 
Verifica-se diante de todo o exposto, que o due process of law representa a possibilidade efetiva de a parte ter acesso à justiça deduzindo pretensão e defendendo-se do modo mais amplo possível. Tamanha é a importância de sua previsão constitucional que não seria demais considerá-lo o vértice de toda ordem democrática e justa. ${ }^{463}$

Na expressão empregada, se deseja resumir a necessidade de associar ao processo um conjunto de garantias que permitam desde a regular instauração até o justo desfecho, dependendo tudo de adequado desenvolvimento em que seja respeitada a possibilidade de defesa, a fundamentação das decisões, a imparcialidade do julgador, o estabelecimento de prévio procedimento, o tratamento igualitário das partes etc. ${ }^{464}$

Após essa breve incursão sobre o devido processo legal, entendemos que se configura duvidoso sustentar a inconstitucionalidade do artigo 285-A do CPC, sob a alegação de ferir referido princípio. Em primeiro lugar, a promulgação da Lei 11.277/06, que trouxe a lume o artigo 285-A no Código de Processo Civil, foi antecedida de regular processo legislativo sendo que, ademais, traz em seu bojo conteúdo que vai ao encontro das aspirações da sociedade por uma justiça célere.

Não é demais mencionar, ainda, que na hipótese do art. 285-A do CPC, por clara opção do legislador, há uma racionalização do caminho do processo. Há uma prévia estipulação de um novo procedimento a ser seguido para uma hipótese particular, as chamadas "demandas repetitivas" que, por evidente, precisa ser acatada. Mantém-se, assim, intacta a possibilidade do autor acionar o Judiciário na busca pelo seu direito, havendo o devido exame da matéria, de forma semelhante a outras demandas que tramitaram por aquele juízo.

Além da obediência às regras processuais, deve ser verificado se o dispositivo em

\footnotetext{
${ }^{463}$ Nelson Nery Júnior destaca que "bastaria a norma constitucional haver adotado o princípio do due process of law para que daí decorressem todas as consequencias processuais que garantiriam aos litigantes o direito a um processo e a uma sentença justa. É, por assim dizer, o gênero do qual todos os demais princípios constitucionais do processo são espécies”. (NERY JÚNIOR, Nelson. Princípios do processo na Constituição Federal: processo civil, penal e administrativo, cit., p. 77).

${ }^{464}$ Sobre o assunto, valiosa a lição de Humberto Theodoro Júnior: "A exemplo da Constituição italiana, também a Carta brasileira foi emendada para explicitar que a garantia do devido processo legal (processo justo) deve assegurar "a razoável duração do processo" e os meios que proporcionem "a celeridade de sua tramitação” (CF, art. 5\%, novo inciso LXXVIII, acrescentado pela Emenda Constitucional 45, de 08.12.2004). Nesse âmbito de comprometimento com o "justo", com a "correção", com a "efetividade" $e$ a "presteza” da prestação jurisdicional, o due process of law realiza, entre outras, a função de um superprincípio, coordenando e delimitando todos os demais princípios que informam tanto o processo como o procedimento. Inspira e torna realizável a proporcionalidade e razoabilidade que deve prevalecer na vigência e harmonização de todos os princípios do direito processual de nosso tempo". (THEODORO JÚNIOR, Humberto. Curso de direito processual civil: teoria geral do direito processual civil e processo de conhecimento, cit., v. 1, p. 27).
} 
análise, em seu conteúdo, está em consonância com o substantive due process, ou seja, se está subordinado aos princípios constitucionais do processo. Ainda que se analise a questão sob o ponto de vista do mérito, percebe-se, claramente, que não há desrespeito ao princípio do devido processo legal. ${ }^{465}$ Isto porque o art. 285-A do CPC nada tem de arbitrário, estando em harmonia com os valores constitucionais, como visto nos tópicos que antecederam a este.

Impende lembrar que sua devida aplicação ao caso concreto, com base em reflexões acerca de razoabilidade e proporcionalidade, possibilita que os processos cumpram celeremente sua marcha, juntamente com a economia de custo, atos e eficiência da administração judiciária, garantindo o efetivo cumprimento das normas processuais existentes. ${ }^{466}$

Neste mesmo sentido, Luiz Guilherme Marinoni entende que não se pode esquecer que "o titular de posição consolidada em casos idênticos tem o direito à pronta tutela do seu direito material, e, ainda, que a racionalidade do processo não admite que um mesmo juízo seja obrigado a proferir fundamentações várias para a solução de ações repetitivas”. ${ }^{467}$

Ressalte-se, assim, que não há óbice para que o Magistrado, dispensando a citação do réu, entenda por bem julgar improcedente, de plano, determinada demanda, não se constituindo tal situação afronta ao princípio do devido processo legal, desde que estejam preenchidos os requisitos especificados no art. 285-A, caput, do Código de Processo Civil.

À luz de todo o exposto no presente Capítulo, conquanto respeitáveis os argumentos favoráveis à inconstitucionalidade do dispositivo, entendemos que referida tese não merece prosperar. Os mencionados princípios do contraditório, da isonomia, acesso à justiça, devido processo legal e segurança jurídica foram instituídos em favor das partes e não são afrontados, inclusive no tocante ao réu, pelo julgamento prima facie de improcedência disciplinado no art. 285-A do CPC.

\footnotetext{
${ }^{465}$ Não é outra a conclusão de Denis Donoso: “O que parece ser uma conclusão inafastável é que o julgamento prévio do mérito passa, após a edição da Lei n. 11.277/2006, a ser parte integrante deste todo denominado devido processo legal". (DONOSO, Denis. Julgamento prévio do mérito: análise do art. 285A do CPC. São Paulo: Saraiva, 2011. p. 99).

${ }^{466}$ Assim se expressa Ada Pellegrini Grinover: "As garantias do devido processo legal, afirmamos em estudos anteriores, devem ser adaptadas à sumarização do processo - de que a técnica do art. 285-A é mais um exemplo -, podendo o contraditório ser diferido e sendo a pedra de toque para a validade do processo a ausência de prejuízo às partes". (GRINOVER, Ada Pellegrini. O tratamento dos processos repetitivos. In: JAIME, Fernando Gonzaga; FARIA, Juliana Cordeiro de; LAUAR, Maira Terra (Coords.). Processo civil: novas tendências: estudos em homenagem ao Professor Humberto Theodoro Júnior. Belo Horizonte: Del Rey, 2008. p. 9).

${ }^{467}$ Cf. MARINONI, Luiz Guilherme. Ações repetitivas e julgamento liminar. Revista Jurídica, Porto Alegre, v. 55 n. 354, p. 61, abr. 2007.
} 


\section{CONSIDERAÇÕES CONCLUSIVAS}

A título de síntese do que foi analisado ao longo do presente estudo, lançamos mão das conclusões que seguem.

A sociedade vem sofrendo, ao longo dos tempos, substancial alteração, tornando imperiosa também a evolução do direito, de modo peculiar do direito processual civil. As compreensões individualistas típicas da doutrina liberal começaram a perder terreno diante das crises sociais, dos avanços tecnológicos e do fenômeno das demandas de massa que passaram a exigir do Estado uma nova conduta.

O problema da demora na tramitação dos feitos tem sido objeto de preocupação tanto no ordenamento pátrio como em outros ordenamentos estrangeiros. As principais causas que contribuem para a demora na prestação jurisdicional podem ser agrupadas em três categorias: fatores estruturais, fatores endoprocessuais e fatores extraprocessuais.

No caso brasileiro, a facilitação do acesso à justiça, além de um contexto social todo peculiar estimulou a cultura da litigância, levando à judicialização de boa parte de todas as crises de direito material surgidas. Ocorre, contudo, que o sistema processual civil não colocava à disposição da sociedade técnicas processuais aptas a tutelar de forma efetiva e célere as novas situações, em especial aquelas atinentes às demandas de massa, que brotaram em número e velocidade muito maior do que o legislador ou o Judiciário estavam aptos a acompanhar.

A solução deste problema, além do fortalecimento das estruturas do Poder Judiciário e da alteração da mentalidade dos operadores do direito, passa pelo aprimoramento das técnicas processuais, em especial aquelas voltadas às situações de massa, que se compõem, na sua grande maioria, de demandas individuais repetitivas que veiculam questões juridicamente idênticas, embora cada ação esteja identificada por titulares de direito diversos.

Nessa toada, foram pensados diversos mecanismos de contenção da litigiosidade de massa. Inicialmente, os mecanismos foram criados para aplicação no âmbito recursal, tais como as técnicas de julgamento por amostragem, súmulas vinculantes, repercussão geral, cujo objetivo era racionalizar a duração do processo e evitar decisões conflitantes. Com o 
decorrer do tempo, contudo, viu-se ser necessário também estender as medidas para o primeiro grau.

Neste panorama, é que foi inserido no direito pátrio o art. 285-A no Código de Processo Civil, objeto do presente estudo, pela Lei 11.277/2006, técnica que permite o julgamento de improcedência, de plano, sem a necessidade de citação do réu, de demandas repetitivas e que tem por intuito dar concretude ao disposto no artigo $5^{\circ}$, inciso LXXVIII, da CF, introduzido pela Emenda Constitucional n. 45, de 2004.

Impende destacar que a improcedência prima facie prevista no art. 285-A do CPC não configura temática inédita no sistema processual, na medida em que já existiam, em nosso ordenamento jurídico, dispositivos que, de certa forma, e ainda que diante de situações específicas e requisitos diversos, possibilitavam o abreviamento do iter procedimental, tais como a sentença que reconhece a prescrição ou decadência e o julgamento prévio de improcedência da ação de improbidade.

Pode-se dizer, então, que o julgamento de plano pela improcedência previsto no art. 285-A fez tão somente tornar a norma mais genérica e abrangente, sendo que atualmente vislumbra-se sua aplicabilidade nos Juizados Especiais Cíveis e Federais, bem como na Justiça do Trabalho.

Com a inclusão do dispositivo em comento, o julgamento do mérito da causa passou a ser possível em três momentos distintos: no primeiro contato do juiz com a petição inicial (art. 285-A do CPC), na fase saneadora, de forma antecipada, nos termos do art. 330 do CPC ou, ainda, finda a fase instrutória (art. 456 do CPC), após o procedimento ser plenamente desenvolvido, com a realização de todas as suas fases cognitivas (postulatória, saneadora, instrutória e decisória).

Das pesquisas levadas a cabo, apesar de a preocupação com a razoável duração dos processos estar presente na maioria dos ordenamentos, existindo diversas normas que procuram abreviar o percurso do processo até o julgamento final, não constatamos nenhuma regra idêntica àquela prevista no art. 285-A do CPC.

Algumas condições despontam como necessárias para que se tenha a aplicação do julgamento de plano de improcedência, fornecidas pelo caput do art. 285-A, quais sejam: a) que a matéria alegada na petição inicial seja unicamente de direito e, sendo de direito e envolvendo matéria fática, esta possa ser comprovada pela prova documental, prescindindo da produção de prova pericial e/ou oral para o julgamento do pedido do autor; b) a 
existência de casos idênticos, isto é, aqueles em que a tese jurídica ventilada na ação em curso tenha sido exatamente a mesma de outras ações julgadas improcedentes, envolvendo tão somente partes diversas, tal qual ocorre com as denominadas demandas repetitivas (fala-se, assim, em similitude entre pedido e causa de pedir, porém entre partes distintas); c) a existência, no juízo (que não se confunde com o "juiz", pessoa física), de anterior sentença de total improcedência (jamais de procedência) em outros casos idênticos.

Saliente-se que a identidade exigida pelo artigo 285-A, do CPC é aquela que incide sobre a causa de pedir e o pedido. Isto porque, caso houvesse identidade de partes, causa de pedir e pedido, estaríamos diante ou de litispendência ou de coisa julgada, conforme o caso.

Sobreleva notar, também, que para aplicação da norma exige-se que não apenas um, mas pelo menos dois casos idênticos tenham sido julgados improcedentes anteriormente, os quais servirão como paradigma para a ação que agora será julgada.

Em que pese existir divergência doutrinária, entende-se que o julgamento nos moldes aqui preconizados configura faculdade do juiz, a quem cabe verificar a conveniência e oportunidade em sua utilização, conforme estejam ou não presentes os requisitos exigidos. Além disso, apesar não haver determinação expressa no dispositivo legal, aconselha-se que o magistrado de primeiro grau proceda na forma do art. 285-A do CPC apenas se o julgado a servir de base para a sentença a ser proferida estiver de acordo com súmulas e posicionamento predominante sobre a matéria.

A sentença que julga o caso novo deve conter os três requisitos exigidos pelo art. 458, do CPC (relatório, fundamentos e dispositivo), apresentando breve apanhado do caso, a fim de que se possa verificar a semelhança com o caso paradigma, para, em seguida, transcrever o mesmo fundamento usado naquele. Não é suficiente a simples referência aos números dos processos julgados naquele sentido, nem tampouco a juntada de cópias dos julgados anteriores.

Peculiaridade notável é, ainda, o fato de que a decisão proferida com fundamento no art. 285-A tem natureza de sentença de mérito, enquadrando-se no disposto no artigo 269, inciso I do Código de Processo Civil. Ademais, em que pese o artigo em comento faça expressa menção a "sentença", o dispositivo terá aplicação em processos de competência originária dos Tribunais, tais como mandados de segurança e ações rescisórias. 
Convém salientar que com a modificação ocorrida no conceito de sentença, pela Lei 11.232/2005, entende-se não haver mais impedimento para que se profiram julgamentos parciais, nas hipóteses em que haja cumulação de pedidos e apenas parcela deles comporte o julgamento com base na norma ora em análise. Deste modo, estando um ou mais pedidos em condições de serem julgados de plano, de acordo com artigo 285-A do CPC, pode o magistrado encerrar o processo em relação a eles (art. 269, I, do CPC), prosseguindo o feito em relação aos demais pedidos.

A fim de evitar tramas processuais de autores inconformados com a sentença de improcedência, entende-se recomendável a intimação do réu acerca do teor do resultado do julgamento, por analogia do disposto no $\S 6^{\circ}$ do art. 219 do CPC, a fim de que possa o mesmo se resguardar invocando os efeitos da coisa julgada na hipótese de ajuizamento de nova ação.

Nas hipóteses em que prevê a lei a necessidade de participação do Ministério Público, na qualidade de custos legis, não deve o magistrado julgar improcedente a demanda, aplicando o art. 285-A do CPC, sem antes chamar o parquet a fim de que este exare seu parecer.

Pouco falou o legislador acerca do desenvolvimento do processo após o julgamento de improcedência de plano, talvez porque imaginasse que o autor se conformaria com a sentença proferida fundamentada na reiterada negativa em casos similares. Fato é que a possibilidade de apelação da sentença e o modo de continuidade do feito estão previstos de forma sucinta nos dois parágrafos do art. 285-A.

$\mathrm{O} \S 1^{\mathrm{o}}$ do artigo traz a faculdade de retratação da sentença pelo magistrado nos casos em que for interposta apelação pelo autor, hipótese em que o juiz poderá reformar a sentença e determinar o prosseguimento do feito. Trata-se de norma bastante similar àquela prevista no artigo 296 do Código de Processo Civil, que retira do mundo jurídico a sentença proferida, passando o processo a tramitar como se nada houvesse acontecido anteriormente. A diferença entre os dispositivos está no prazo, já que o $\S 1^{\circ}$ do art. 285-A estabelece o prazo de 5 (cinco) dias, e não de apenas 48 (quarenta e oito horas) como prevê o art. 296 do CPC.

Não havendo retratação, isto é, mantida a sentença pelo juiz, dispõe o $§ 2^{\circ}$ do artigo que o réu deverá ser citado para responder ao recurso. É aqui que o silêncio do legislador se faz sentir. Isto porque o réu se integra à relação jurídica processual com a causa já 
julgada. Aqui, os princípios, ainda que não positivados, ganham papel de destaque e foram trabalhados como pano de fundo para melhor sistematização.

De acordo com a dicção legal, o réu é chamado a juízo para responder ao recurso do autor, não à demanda, daí porque há controvérsia acerca do papel da citação no feito, bem como em torno da natureza dessa resposta, parecendo-nos razoável aceitar que as contrarrazões do réu terão conteúdo muito semelhante ao de uma contestação, já que se trata de sua primeira manifestação no processo, devendo, porém, ter como argumento principal a ausência de identidade entre a sentença paradigma e a sentença objeto do recurso.

No que se refere a outras modalidades de resposta do réu, ficou evidenciado que o pedido reconvencional não se harmoniza com o julgamento prévio de improcedência, tampouco parece razoável, em que pese possível, a apresentação das exceções de suspeição, impedimento e incompetência relativa. Tanto o autor quanto o réu podem apresentar embargos de declaração se presentes os requisitos previstos no art. 535 do CPC.

De se destacar a relevância do princípio da fungibilidade, em especial para resolver aqueles casos em que surgem dúvidas quanto ao recurso cabível, tal qual ocorre para alguns nos casos em que o juiz julga, de plano, tão somente parcela dos pedidos formulados pelo autor na inicial e que apresentam os requistos autorizadores apresentados pela norma, determinando o regular prosseguimento da demanda com relação aos demais pedidos que não comportam o julgamento nos moldes traçados pelo art. 285-A.

Verifica-se que o estudo do art. 285-A do CPC deve ser feito em harmonia com outros dispositivos. Assim, por exemplo, nos termos do $\S 1^{\circ}$ do art. 518 do CPC, o juiz não admitirá o recurso de apelação interposto pela parte quando este estiver em desconformidade com o julgamento de súmula do STJ ou do STF.

Possível e altamente recomendável é, ainda, a aplicação conjunta do art. 285-A com o art. 557, caput, do CPC, o que pode tornar ainda mais célere a tramitação processual.

Em seu julgamento, o Tribunal pode adotar uma das seguintes condutas: i) negar provimento à apelação, mantendo a decisão de primeira instância; ii) dar provimento ao recurso e julgar desde logo o pedido nos termos do $\S 3^{\circ}$ do art. 515 do CPC, caso entenda tratar-se de causa madura, oportunizando, preferencialmente, o contraditório, a fim de evitar efeito surpresa; iii) o Tribunal deverá, contudo, se restringir a anular a sentença e determinar o regular processamento da causa em primeiro grau, quando verificar que há 
questões a esclarecer que demandam dilação probatória e que, por tal motivo, não poderia ter sido aplicado o art. 285-A (error in procedendo).

Não se vislumbra qualquer óbice à possibilidade de o Tribunal, ao confirmar a sentença do juiz a quo proferida com base no art. 285-A do CPC, condenar o apelante em honorários advocatícios em favor do apelado, não configurando tal conduta afronta ao princípio da proibição de reformatio in pejus.

Julgando com fundamento no artigo 285-A do CPC, o magistrado emite pronunciamento de mérito acerca do pedido. Logo, não havendo recurso de apelação, a sentença ficará acobertada pelo manto da coisa julgada formal e material.

No que diz respeito à alegada inconstitucionalidade da norma, tal qual argumentou o Conselho Federal da Ordem dos Advogados do Brasil quando ajuizou a ação direta de inconstitucionalidade (ADIn) $n^{\circ} 3695$, temos que a mesma não merece prosperar.

Analisando separadamente cada um dos princípios supostamente afrontados e confrontando-os com o art. 285-A do CPC, conclui-se que o dispositivo não macula os princípios constitucionais regentes do processo civil: isonomia, segurança jurídica, direito de ação, devido processo legal e contraditório. Senão vejamos.

Não há violação à isonomia constitucional, pois apesar de haver abreviação no caminho que leva até a prolação da sentença, não há que se falar em tratamento desigual entre as partes, já que o magistrado, dada a presenças de certos requisitos previamente estipulados, aplica o mesmo direito a situações análogas, sendo que os entendimentos divergentes entre juízos diferentes será objeto de análise posterior pelos Tribunais.

Também a segurança jurídica, que possui como fundamento a previsibilidade e a estabilidade, é observada pelo art. 285-A, do CPC. A adoção do entendimento veiculado em anteriores sentenças de improcedência proferidas pelo juízo possibilita aos jurisdicionados previsibilidade acerca do posicionamento sobre um determinado assunto, já que as sentenças, com poucas exceções são públicos, a teor do que dispõe o art. 93, IX da Constituição Federal Ademais, resguarda-se a estabilidade, na medida em que há uma antecipação de decisão final já conhecida de antemão, cabendo recurso contra a má aplicação do dispositivo.

Igualmente, o artigo 285-A, do CPC também não possui pecha de inconstitucionalidade por ferir o acesso à Justiça, uma vez este já é exercitado com o 
simples acesso ao Judiciário, e o autor terá sua pretensão analisada de forma fundamentada, somente de forma mais abreviada.

$\mathrm{O}$ art. 285-A, do CPC não engendra nenhuma limitação ao contraditório e à ampla defesa, já que não se inibe a participação das partes no processo, tampouco o direito de influenciar, quando necessário, a convicção do magistrado. De fato, o réu, até que haja eventual apelação, não tem interesse processual em vir ao processo trazer seus argumentos, haja vista que o magistrado, com base em outros casos idênticos por ele já decididos, já possui sua conviç̧ão formada acerca daquele tema, a qual lhe é favorável. Assim, inexiste a suposta lesão ao contraditório, como alhures delineado, sendo que este é apenas diferido para momento posterior. À parte autora fica reconhecida a possibilidade de recorrer e o réu também não sofre nenhuma restrição, pois foi vencedor e, em caso de recurso, será citado, oportunidade em que poderá apresentar a defesa do seu interesse.

Também não há violação do princípio do devido processo legal, pois, além da edição do art. 285-A ter sido precedida de regular processo legislativo, a aplicação do dispositivo, por estar em conformidade com o princípio da duração razoável dos processos, vem ao encontro dos desejos por justiça célere e efetiva.

A técnica do julgamento de improcedência prima facie proferido com fundamento no art. 285-A do CPC leva à seguinte reflexão: diante da realidade contemporânea do Judiciário e do sistema processual civil atual, essa opção legislativa de encurtamento do iter procedimental se justifica? Após a análise realizada, pode-se concluir que a faculdade atribuída aos magistrados, desde que adotada com cuidado e bom senso, é de extrema valia para o processo, haja vista que privilegia a economia e celeridade processual, trazendo benefícios tanto para o autor quanto para o réu.

A referida técnica beneficia o autor da demanda, na medida em que este terá uma resposta jurisdicional imediata à sua postulação, bem como não precisará arcar com os honorários de sucumbência em primeira instância. O réu, por sua vez, tem seus direitos e interesses resguardados por inteiro, de forma rápida e sem a necessidade de contratar serviços advocatícios.

O projeto de novo Código de Processo Civil, ainda que de maneira mais tímida, possui dispositivo expresso (art. 307, do PL 8046/2010) prevendo a improcedência liminar do pedido, incorporando, ainda, em seu $\S 1^{\circ}$, a hipótese de julgamento de improcedência para os casos em que se verificar a ocorrência de decadência ou prescrição. O art. 307 do 
projeto do novo CPC acompanha a tendência presente em diversos artigos do atual Código no sentido de potencializar a força dos precedentes judiciais, privilegiando a uniformização dos julgados.

Dentro desta ótica, é de se concluir, finalmente, ser extremamente relevante a adaptação das técnicas processuais às exigências da sociedade e do direito material. $\mathrm{O}$ art. 285-A do CPC não afronta as garantias fundamentais do processo de forma a ensejar eventual inconstitucionalidade; se o referido dispositivo processual for bem utilizado, pode contribuir com o Judiciário no sentido de dar vazão às denominadas demandas repetitivas, naqueles casos em que já se sabe, em virtude de julgamentos anteriormente proferidos, que as mesmas se encontram fadadas à improcedência, proporcionando a todos os envolvidos um resultado concreto positivo. 


\section{REFERÊNCIAS}

ALMEIDA, Diogo Assumpção Rezende de. O Case Management inglês: um sistema maduro? Revista Eletrônica de Direito Processual - REDP, São Paulo, v. 2, p. 287-335. Disponível em: <http://www.redp.com.br/arquivos/redp_7a_edicao.pdf>. Acesso em: 23 dez. 2012.

ALMEIDA, José Antonio. O agravo interno e a ampliação dos poderes do relator. In: NERY JÚNIOR, Nelson; WAMBIER, Teresa Arruda Alvim (Coord.). Aspectos polêmicos e atuais dos recursos cíveis e de outros meios de impugnação às decisões judiciais. São Paulo: Ed. Revista dos Tribunais, 2003. v. 7.

ALVIM, Arruda. A EC. N. 45 e o Instituto da Repercussão Geral. WAMBIER, Tereza Arruda Alvim et al. (Coord.) Reforma do Judiciário: primeiras reflexões sobre a Emenda Constitucional n. 45/2004. São Paulo: Ed. Revista dos Tribunais. 2005.

Manual de direito processual civil. 13. ed. São Paulo: Ed. Revista dos Tribunais, 2010.

. Princípios constitucionais na Constituição Federal de 1988 e o acesso à justiça. Revista do Advogado, São Paulo, n. 34, jul. 1991.

ALVIM, Eduardo Arruda. Do julgamento de improcedência de casos repetitivos, à luz da lei $\mathrm{n}^{\circ}$ 11.277/2006 - algumas reflexões atinentes ao art. 285-A do CPC. Revista Forense, Rio de Janeiro, v. 103, n. 393, p. 39-51, set./out. 2007.

AMORIM FILHO, Agnelo. Critério científico para distinguir a prescrição da decadência e para identificar as ações imprescritíveis. In: NERY JÚNIOR, Nelson; NERY, Rosa Maria Andrade (Orgs.). Responsabilidade civil: teoria geral. São Paulo: Ed. Revista dos Tribunais, 2010. v. 1, p. 779-814.

ANDREWS, Neil. O moderno processo civil: formas judiciais e alternativas de resolução de conflitos na Inglaterra. Orientação e revisão da tradução Teresa Arruda Alvim Wambier. São Paulo: Ed. Revista dos Tribunais, 2009.

ARAÚJO, José Henrique Mouta. Súmula impeditiva de recursos: uma visão sobre o atual quadro processual brasileiro. Revista Dialética de Direito Processual, São Paulo, n. 39, jun. 2006. 
ARAÚJO, Luciano Vianna. 285-A do CPC (julgamento imediato, antecipado e maduro da lide): evolução do sistema desde o código de processo civil de 1939 até 2007. Revista de Processo, São Paulo, v. 33 n. 160, p. 157-179, jun. 2008.

ASSIS, Araken de. Manual dos recursos. São Paulo: Ed. Revista dos Tribunais, 2007.

ATAÍDE JÚNIOR, Vicente de Paula. A resolução antecipada do mérito em ações repetitivas (lei 11277/2006). Revista de Processo, São Paulo, v. 31 n. 141, nov. 2006.

BAPTISTA, José João. Processo Civil I: parte geral e processo declarativo. 8. ed. Coimbra: Coimbra Ed., 2006.

BARBOSA MOREIRA, José Carlos. Comentários ao Código de Processo Civil. 12. ed. Rio de Janeiro: Forense, 2005, v. 5.

A duração dos processos: alguns dados comparativos. Revista Síntese de Direito Civil e Processual Civil, v. 5, n. 29, p. 28-36, maio/jun. 2004.

BARBOSA, Rui. Oração aos moços. 5. ed. Edição popular anotada por Adriano de Gama Cury. Rio de Janeiro: Edições Casa de Rui Barbosa, 1999. p. 25. Disponível em: <http://www.casaruibarbosa.gov.br/dados/DOC/artigos/rui_barbosa/FCRB_RuiBarbosa_O racao_aos_mocos.pdf>. Acesso em: 28 out. 2012.

BARIONI, Rodrigo. O recurso extraordinário e as questões constitucionais de repercussão geral. WAMBIER, Teresa Arruda Alvim (Coord.). Reforma do Judiciário. São Paulo: Ed. Revista dos Tribunais, 2005. p. 721-734.

BEDAQUE, José Roberto dos Santos. Efetividade do processo e técnica processual. 2. ed. São Paulo: Malheiros Ed., 2007.

- Garantia da amplitude de produção probatória. In: CRUZ E TUCCI, José Rogério (Coord.). Garantias constitucionais do processo civil. São Paulo: Ed. Revista dos Tribunais, 1999.

BERMUDES, Sério. Direito processual civil: estudos e pareceres: $2^{\text {a }}$ série. 2. ed. São Paulo: Saraiva, 1994.

Introdução ao processo civil. Rio de Janeiro: Forense, 1995.

A reforma do Judiciário pela Emenda Constitucional $N^{o}$ 45. Rio de Janeiro: Forense, 2005. 
BÉZE, Patrícia Mothé Glioche. Devido processo legal. In: TORRES, Ricardo Lobo; KATAOBA, Eduardo Takemi; GALDINO, Flavio (Org.). Dicionário de princípios jurídicos. Rio de Janeiro: Elsevier, 2011.

BONDIOLI, Luís Guilherme Aidar. Os embargos declaratórios sob a ótica da efetividade. Dissertação (Mestrado) - Faculdade de Direito, Universidade de São Paulo, São Pualo, 2004.

O julgamento liminar de improcedência da demanda da óptica do réu (art. 285-A do CPC). Revista Jurídica, Porto Alegre, v. 56, n. 367, p. 19-20, maio 2008.

BORGES, José Souto Maior. O princípio da segurança jurídica na criação e aplicação do tributo. Revista de Direito Tributário, n. 63, p. 206-210, jan./ mar. 1994.

Significação do princípio da isonomia na Constituição de 1988. Revista Trimestral de Direito Público, São Paulo, n. 15, p. 31-33, 1996.

BOTELHO DE MESQUITA, Ignácio. A garantia do devido processo legal - aplicação contra excesso do Ministério Público. Revista Forense, Rio de Janeiro, v. 327, p. 149-154, jul./set. 1994.

BRAGHITTONI, Rogério Ives. O princípio do contraditório no processo: doutrina e prática. Rio de Janeiro: Forense Universitária, 2002.

BRESOLIN, Umberto Bara. Considerações sobre o artigo 285-A do Código de Processo Civil. CARMONA, Carlos Alberto. Reflexões sobre a reforma do Código de Processo Civil. 1. ed. São Paulo: Atlas, 2007. v. 1.

BRUNINI, Gabriela Zancaner. Considerações sobre o princípio da isonomia. Revista Trimestral de Direito Público, São Paulo, n. 46, 2004.

BRUSCHI, Gilberto Gomes. Casos idênticos e os requisitos para a aplicação do art. 285-A do CPC. Revista Dialética de Direito Processual, São Paulo, n. 78, set. 2009.

BUENO, Cássio Scarpinella. Curso Sistematizado de direito processual civil. 3. ed. São Paulo: Saraiva, 2009. v. 1.

Mandado de segurança: comentários às Leis n. 1.533/51, 4.348/64 e 5.021/66. 5. ed. São Paulo: Saraiva, 2009.

A nova etapa do código de processo civil: comentários sistemáticos às Leis n. 11.276 de 7-2-2006, 11.277, de 7-2-2006, e 11.280, de 16-2-2006. São Paulo: Saraiva, 2006. v. 2. 
CABRAL, Antonio do Passo. Contradiório. In: TORRES, Ricardo Lobo; KATAOBA, Eduardo Takemi; GALDINO, Flavio (Org.). Dicionário de princípios jurídicos. Rio de Janeiro: Elsevier, 2011.

CÂMARA DOS DEPUTADOS. Projeto de Lei n. ${ }^{\circ}$ 4.728, de 2004. Disponível em: <http://www.camara.gov.br/proposicoesWeb/prop_mostrarintegra;jsessionid=8B69B11D2 97D0322DB9B0153DB0F8AEC.node2? codteor=272449\&filename=Avulso+PL+4728/2004>. Acesso em: 23 out. 2012.

CÂMARA, Alexandre Freitas. Ação rescisória. Rio de Janeiro: Lumen Juris, 2007. Lições de direito processual civil. 15. ed. Rio de Janeiro: Lumen Juris, 2006. v. 1.

CÂMARA LEAL, Antônio Luiz da. Da prescrição e decadência. 3. ed. Rio de Janeiro: Ed. Forense, 1978.

CAMBI, Eduardo. Julgamento prima facie (imediato) pela técnica do art. 285-A do CPC. Disponível em <www.abdpc.org.br/artigos/artigo1033.doc>. Acesso em: 09 jun. 2011.

CANOTILHO, José Joaquim Gomes. Direito constitucional e teoria da Constituição. 6. ed. Coimbra: Almedina, 2003.

CAPPELlETTI, Mauro; GARTH, Bryant. Acesso à justiça. Trad. de Ellen Gracie Northfleet. Porto Alegre: Fabris, 2002.

CARMONA, Carlos Alberto. Recurso extraordinário: uma análise do acesso do Supremo Tribunal Federal. São Paulo: Atlas, 2007.

CARNEIRO, Athos Gusmão. Intervenção de terceiros. São Paulo: Saraiva, 2008.

. Poderes do relator e Agravo Interno - Arts. 557, 544 e 545 do CPC. Revista de Processo, São Paulo, v. 25 n. 100, out./ dez. 2000.

CARNELUTTI, Francesco. Diritto e processo. Napoli: Morano, 1958.

CASTRO, Carlos Roberto Siqueira. O devido processo legal e os princípios da razoabilidade e da proporcionalidade. Rio de Janeiro: Forense, 2010.

CAVAlCANTE, Mantovanni Colares. A sentença liminar de mérito do art. 285-A do Código de Processo Civil e suas restrições. Revista Dialética de Direito Processual, São Paulo, n. 42, p. 95-104, set. 2006. 
CERQUEIRA, Fábio Ruiz; MAIDAME, Márcio Manoel. Art. 285-A do CPC: fundamentos, importância e aplicabilidade no processo civil brasileiro. In: ALVIM, Arruda; ARRUDA ALVIM, Eduardo. Atualidades do processo civil. Curitiba: Juruá, 2007. v. 1.

CERQUEIRA, Luís Otávio Sequeira de. O princípio da fungibilidade e os poderes do juiz. In: MEDINA, José Miguel Garcia et al (Coord.). Os poderes do juiz e o controle das decisões judiciais: estudos em homenagem à Professora Teresa Arruda Alvim Wambier. São Paulo: Ed. Revista dos Tribunais, 2008.

LA CHINA, Sergio. L'esecuzione forzata e le disposizioni generali del Codice di Procedura Civile. Milano: Giuffrè, 1970.

CIANCI, Mirna. O acesso à justiça e as reformas do CPC. São Paulo: Saraiva, 2009. (Coleção direito e processo - Coordenador Cássio Scarpinella Bueno).

—. A prescrição na Lei 11.280, de 2006. Disponível em: $<$ http://www.migalhas.com.br/dePeso/16,MI31614,51045-

A+Prescricao+na+Lei+11280+de+2006>. Acesso em: 16 dez. de 2012.

CIMARDI, Cláudia A. Notas sobre o art. 285-A do CPC (sentença liminar de improcedência). In: MEDINA, José Miguel Garcia et al (Coord.). Os poderes do juiz e o controle das decisões judiciais: estudos em homenagem à Professora Teresa Arruda Alvim Wambier. São Paulo: Ed. Revista dos Tribunais, 2008.

CINTRA, Antônio Carlos de Araújo; DINAMARCO, Cândido Rangel; GRINOVER, Ada Pellegrini. Teoria geral do processo. 26. ed. São Paulo: Malheiros Ed., 2010.

COELHO, Gláucia Mara. Direito processual civil português. In: CRUZ E TUCCI, José Rogério (Coord.). Direito processual civil europeu contemporâneo. São Paulo: Lex Ed., 2010.

COMOGLIO, Luigi Paolo. La garanzia dell'azzione e il processo civile. Padova: Cedam, 1970 .

CONSELHO NACIONAL DE JUSTIÇA. Demandas repetitivas e a morosidade na justiça cível brasileira. Disponível em: <http://www.cnj.jus.br/images/pesquisasjudiciarias/Publicacoes/pesq_sintese_morosidade_dpj.pdf>. Acesso em 29 nov. 2012.

CORREIA, André de Luizi. A citação no direito processual civil brasileiro. São Paulo: Ed. Revista dos Tribunais, 2001. 
CRETELLA NETO, José. Fundamentos principiológicos do processo civil. Rio de Janeiro: Forense, 2002.

CRUZ E TUCCI, José Rogério. Direito processual civil inglês. In: CRUZ E TUCCI, José Rogério (Coord.). Direito processual civil europeu contemporâneo. São Paulo: Lex Ed., 2010.

Limites subjetivos: da eficácia da sentença e da coisa julgada civil. São Paulo: Ed. Revista dos Tribunais, 2006.

- Tempo e processo: uma análise empírica das repercussões do tempo na fenomenologia processual (civil e penal). São Paulo: Ed. Revista dos Tribunais, 1997.

CUNHA, Leonardo Carneiro da. Anotações sobre o incidente de resolução de demandas repetitivas previsto no Projeto de Novo Código de Processo Civil. Revista de Processo, São Paulo, v. 36, n. 193, p. 255-279, mar. 2011.

- Primeiras impressões sobre o art. 285-A do CPC (julgamento imediato de processos repetitivos: uma racionalização para as demandas de massa). Revista Dialética de Direito Processual, n. 39 jun. 2006.

DECLARAÇÃO UNIVERSAL DOS DIREITOS HUMANOS. Adotada e proclamada pela resolução 217 A (III) da Assembléia Geral das Nações Unidas em 10 de dezembro de 1948.

Disponível

em:

$<$ http://portal.mj.gov.br/sedh/ct/legis_intern/ddh_bib_inter_universal.htm>. Acesso em: 27 out. 2012.

DELGADO, José Augusto. O princípio da segurança jurídica: supremacia constitucional. Brasília, DF, 2005. Disponível em: <http://bdjur.stj.gov.br/dspace/handle/2011/448>. Acesso em: 31 out. 2012.

Reforma do poder judiciário: art. 5, LXXVIII, da CF. In: WAMBIER, Teresa Arruda Alvim (Coord.). Reforma do Judiciário: primeiros ensaios críticos sobre a EC $\mathrm{n}^{\circ}$ 45/2004. São Paulo: Ed. Revista dos Tribunais, 2005.

DIAS, Luciana Drimel. Dossiê Itália: a grave e profunda crise da duração dos processos/ alerta e subsídio. Revista de Direito Processual Civil Genesis, Curitiba, v. 7, n. 26, p. 779820, out./dez. 2002.

DIAS, Jefferson Aparecido. Princípio do devido processo legal. In: OLIVEIRA NETO, Olavo de; LOPES, Maria Elizabeth de Castro (Orgs.). Princípios processuais civis na Constituição. Rio de Janeiro: Elsevier Campus, 2008. p. 25-46. 
DIDIER JÚNIOR, Fredie. Curso de direito processual civil: introdução ao direito processual civil e processo de conhecimento. 14. ed. Salvador: Ed. Juspodivm, 2012. v. 1.

- Curso de direito processual civil: teoria geral do processo e processo de conhecimento. 14. ed. Salvador: Ed. JusPodivm, 2012. v. 1.

- Razões para um novo CPC. Confiteor. Fredie Didier. Disponível em: $<$ http://www.jurisciencia.com/noticias/razoes-para-um-novo-cpc-confiteor-frediedidier/1523/>. Acesso em: $01 \mathrm{dez} .2012$.

; BRAGA, Paula Sarno; OLIVEIRA, Rafael. Curso de direito processual civil: teoria geral da prova, direito probatório, teoria do precedente, decisão judicial, coisa julgada e antecipação dos efeitos da tutela. 7. ed. Salvador: Ed. Jus Podivm, 2012. v. 2.

; CUNHA, Leonardo Carneiro da. Curso de direito processual civil: meios de impugnação às decisões judiciais e processo nos tribunais. 10. ed. Salvador: Ed. Jus Podivm, 2012. v. 3.

DINAMARCO, Cândido Rangel. Instituições de direito processual civil. 6. ed. São Paulo: Malheiros Ed., 2009. v. 1.

Instituições de direito processual civil. 6. ed. São Paulo: Malheiros Ed., 2002. v. 3.

A reforma do Código de Processo Civil. São Paulo: Malheiros Ed., 2001.

- O relator, a jurisprudência e os recursos. In: NERY JÚNIOR, Nelson;

WAMBIER, Teresa Arruda Alvim (coord.). Aspectos polêmicos e atuais dos recursos cíveis de acordo com a lei 9.756/98. São Paulo: Ed. Revista dos Tribunais, 1999.

DINIZ, Maria Helena. Curso de direito civil brasileiro: teoria geral do direito civil. 24. ed. São Paulo: Saraiva, 2007. v. 1.

DONIZETTI, Elpídio. Curso didático de direito processual civil. 12. ed. Rio de Janeiro: Lumen Juris, 2009.

DONOSO, Denis. Julgamento prévio do mérito: análise do art. 285-A do CPC. São Paulo: Saraiva, 2011.

DUARTE, Ricardo Quass. O tempo inimigo no processo civil brasileiro. São Paulo: LTr, 2009.

ESPÍNDOLA, Ruy Samuel. Conceito de princípios constitucionais: elementos teóricos para uma formulação dogmática constitucionalmente adequada. 9. ed. rev. atual. e ampl. São Paulo: Ed. Revista dos Tribunais, 2002. 
FALTA de juízes explica lentidão da Justiça, aponta pesquisa. Disponível em: $<$ http://veja.abril.com.br/noticia/brasil/falta-de-juizes-explica-lentidao-da-justica-apontapesquisa>. Acesso em 04 dez. 2012.

FARIA, José Eduardo. A crise do poder judiciário no Brasil. Justiça e Democracia, São Paulo, n. 1, p. 18-64, jan./jun. 1996.

FAZZALARI, Elio. Istituzioni di diritto processuale. 8. ed. Padova: CEDAM, 1996.

FAZZIO JÚNIOR, Waldo. Improbidade administrativa: doutrina, legislação e jurisprudência. São Paulo: Atlas, 2012.

FEDERAL Rules of Civil Procedure With Forms, as amended to December 1, 2010. U.S. Government Printing Office - Washington: 2010. Disponível em: $<$ http://www.uscourts.gov/uscourts/RulesAndPolicies/rules/2010\%20Rules/Civil\%20Proce dure.pdf>. Acesso em: 24 de dez. 2012.

FONSECA, Carlos Simões. Sincretismo processual e acesso à justiça. São Paulo: LTr, 2009.

FREIRE JÚNIOR, Américo Bedê. A proibição de "reformatio in peju" e o novo art. 285A. Jus Navigandi, Teresina, ano 10, n. 1091, 27 jun. 2006. Disponível em: <http://jus2.uol.com.br/doutrina/texto.asp?id=8565>. Acesso em: 13 maio 2010.

FREITAS, José Manuel Lebre de. A exigência de celeridade e os princípios processuais (a experiência portuguesa). Revista da Faculdade de Direito do Sul de Minas, Pouso Alegre, v. 26, n. 2, p. 181-194, jul./dez. 2010.

FREITAS, Vladimir Passos de. [Entrevista concedida a Aline Pinheiro]. Revista Consultor Jurídico, 18 mar. 2007. Disponível em: <http://www.conjur.com.br/2007-mar18/nao_aposentadoria_doenca_judiciario?pagina=4>. Acesso em: 27 nov. 2012.

FUX, Luiz. Mandado de Segurança. 1. ed. Rio de Janeiro: Forense. 2010.

GAJARDONI, Fernando da Fonseca. Flexibilização procedimental. São Paulo: Atlas, 2008.

O princípio constitucional da tutela jurisdicional sem dilações indevidas e o julgamento antecipadíssimo da lide. In: CALDERIA, Adriano. Terceira etapa da reforma do código de processo civil: estudos em homenagem ao ministro José Augusto Delgado. Salvador: JusPodivm, 2007. 
GALANTER, Marc. Afterword: explaining litigation. Law and Society Review, v. 9, p. 347-368, $1975 . \quad$ Disponível em: $<$ http://marcgalanter.net/Documents/afterwardexplaininglitigation.pdf>. Acesso em: 04 dez. 2012.

GERALDES, António Santos Abrantes. Temas da reforma do processo civil. 4. ed. rev. e actual. Coimbra: Almedina, 2004. v. 1.

GODOY, Arnaldo Sampaio de Moraes. Processo civil dos EUA buscou excepcionalismo. Revista Consultor Jurídico, 16 mar. 2011. Disponível em: $<$ http://www.conjur.com.br/2011-mar-16/tudo-eua-construcao-processo-civil-buscouexcepcionalismo?pagina=4>. Acesso em: $23 \mathrm{dez} .2012$.

GONÇALVES, Helena de Toledo Coelho. Contraditório e ampla defesa. Curitibva: Juruá Ed., 2010.

GRECO, Leonardo. O princípio do contraditório. Revista Dialética de Direito Processual, São Paulo, n. 24, p. 79, mar. 2005.

GRECO FILHO, Vicente. Direito processual civil brasileiro. 16. ed. atual. São Paulo: Saraiva, 2003. v. 3.

. Direito processual civil brasileiro. 19. ed. São Paulo: Saraiva, 2008. v. 2.

Direito processual civil brasileiro. 20. ed. São Paulo: Saraiva, 2009. v. 2.

GRINOVER, Ada Pellegrini. A crise do Poder Judiciário. In: O processo em evolução. 2. ed. Rio de Janeiro: Forense Universitária, 1998.

O julgamento antecipado da lide: enfoque constitucional. Revista de Processo, São Paulo, v. 2 n. 5, p. 101-112, jan./ mar. 1977.

- Mudanças estruturais no processo civil brasileiro. Revista IOB de Direito Civil e Processo Civil. Porto Alegre:, v. 8, n. 44, p. 35-55, nov./dez. 2006.

. O tratamento dos processos repetitivos. In: JAIME, Fernando Gonzaga; FARIA, Juliana Cordeiro de; LAUAR, Maira Terra (Coords.). Processo civil: novas tendências: estudos em homenagem ao Professor Humberto Theodoro Júnior. Belo Horizonte: Del Rey, 2008.

HM COURTS \& TRIBUNALS SERVICE. The small claims track in civil courts. Disponível em: <http://hmctsformfinder.justice.gov.uk/courtfinder/forms/ex306-eng.pdf>. Acesso em: 23 dez. 2012. 
JAIME, Fernando Gonzaga; FARIA, Juliana Cordeiro de; LAUAR, Maira Terra (Coords.). Processo civil: novas tendências: estudos em homenagem ao Professor Humberto Theodoro Júnior. Belo Horizonte: Del Rey, 2008.

JORGE, Flávio Cheim. Teoria geral dos recursos cíveis. 5. ed. São Paulo: Ed. Revista dos Tribunais, 2011.

; DIDIER JR., Fredie; RODRIGUES, Marcelo Abelha. A terceira etapa da reforma processual civil, comentários às leis 11.187 e 11.232, de 2005; 11.276, 11.277 e 11.280, de 2006. São Paulo: Saraiva, 2006.

KLIPPEL, Rodrigo; SARTÓRIO, Élvio Ferreira. A aplicação do art. 285-A ao julgamento dos mandados de segurança de competência originária dos tribunais. In: ALVIM, Arruda; ARRUDA ALVIM, Eduardo. Atualidades do processo civil. Curitiba: Juruá, 2007. v. 1.

KOEHLER, Frederico Augusto Leopoldino. Breve análise sobre alguns aspectos polêmicos da sentença liminar de improcedência (artigo 285-A do CPC). Revista Dialética de Direito Processual, São Paulo, n. 41, ago. 2006.

LASPRO, Oreste Nestor de Souza. Devido processo legal e a irreversibilidade da antecipação dos efeitos da tutela jurisdicional. In: MARINONI, Luiz Guilherme (Coord.). Estudos de direito processual civil: homenagem ao professor Egas Dirceu Moniz de Aragão. São Paulo: Ed. Revista dos Tribunais, 2005.

Duplo grau de jurisdição no direito processual civil. São Paulo: Ed. Revista dos Tribunais, 1995.

LEONEL, Ricardo de Barros. Revisitando a teoria geral dos recursos: o efeito suspensivo. p. 1-46, Disponível em: < http://www.justitia.com.br/artigos/b9yc1y.pdf>. Acesso em: 27 nov. 2012.

LIEBMAN, Enrico Tulio. Parte o "capo" di sentenza. Revista di Diritto Processuale Civile, Padova, n. 5, 1964.

LIMA, Patrícia Carla de Deus. Notas sobre o julgamento da apelação do art. 285-A do CPC. In: NERY JÚNIOR, Nelson; WAMBIER, Teresa Arruda Alvim (Coord.). Aspectos polêmicos e atuais dos recursos cíveis e assuntos afins. São Paulo: Ed. Revista dos Tribunais, 2007. v. 11.

LÔBO, Paulo Luiz Netto. Igualdade. In: TORRES, Ricardo Lobo; KATAOBA, Eduardo Takemi; GALDINO, Flavio (Org.). Dicionário de princípios jurídicos. Rio de Janeiro: Elsevier, 2011. 
LOPES, Maria Elizabeth de Castro. Princípio do contraditório. In: OLIVEIRA NETO, Olavo de; LOPES, Maria Elizabeth de Castro (Orgs.). Princípios processuais civis na Constituição. Rio de Janeiro: Elsevier Campus, 2008.

LÖWENTHAL, Paulo Friedrich Wilhelm. As origens do devido processo legal substancial e o seu desenvolvimento na Suprema Corte norte-americana. Revista de Direito Constitucional e Internacional, v. 19, n. 75, p. 306, abr./ jun. 2011.

LUCCA, Rodrigo Ramina de. Resolução liminar do mérito. Revista Dialética de Direito Processual, São Paulo, n. 79, p. 115-135, out. 2009.

LUCON, Paulo Henrique dos Santos. Devido processo legal substancial. Disponível em: $<$ http://www.revistadoutrina.trf4.jus.br/index.htm?http://www.revistadoutrina.trf4.jus.br/ar tigos/edicao015/paulo_lucon.htm>. Acesso em: 25 out. 2012.

Prescrição, decadência e processo civil. In: JAIME, Fernando Gonzaga; FARIA, Juliana Cordeiro de; LAUAR, Maira Terra (Coords.). Processo civil: novas tendências: estudos em homenagem ao Professor Humberto Theodoro Júnior. Belo Horizonte: Del Rey, 2008.

MACHADO, Antônio Cláudio da Costa. Código de Processo Civil interpretado e anotado: artigo por artigo, parágrafo por parágrafo. 4. ed. São Paulo: Manole, 2012.

Relatório sobre novo CPC na Câmara é autoritário. Consultor Jurídico, 29 ago. 2012. Disponível em: <http://www.conjur.com.br/2012-ago-29/costa-machado-relatoriocpc-camara-autoritario>. Acesso em: $01 \mathrm{dez} .2012$.

MACIEL, Adhemar Ferreira. Mandado de segurança: direito líqüido e certo. BDJur, Brasília, DF, 11 dez. 2007. Disponível em: <http://bdjur.stj.gov.br/dspace/handle/2011/11481>. Acesso em: 01 jan. 2011.

MANCUSO, Rodolfo de Camargo. Acesso à justiça: condicionantes legítimas e ilegítimas. São Paulo: Ed. Revista dos Tribunais, 2011.

A jurisprudência, dominante ou sumulada, e sua eficácia contemporânea. In: NERY JÚNIOR, Nelson; WAMBIER, Teresa Arruda Alvim (coord.). Aspectos polêmicos e atuais dos recursos cíveis de acordo com a lei 9.756/98. São Paulo: Ed. Revista dos Tribunais, 1999.

A resolução dos conflitos e a função judicial no contemporâneo Estado de direito (nota introdutória). Revista dos Tribunais, São Paulo, v. 98, n. 888, out. 2009. 
MARCATO, Antonio Carlos. Considerações sobre o julgamento de causas repetitivas. Disponível em <http://www.cartaforense.com.br/conteudo/artigos/consideracoes-sobre-ojulgamento-de-causas-repetitivas/4509>. Acesso em: 13 maio 2009.

Crise da Justiça e influência dos precedentes judiciais no direito processual civil brasileiro. Tese (Professor Titular) - Faculdade de Direito, Universidade de São Paulo, São paulo, 2008.

MARINONI, Luiz Guilherme. Ações repetitivas e julgamento liminar. Revista Jurídica, Porto Alegre, v. 55, n. 354, abr. 2007.

. Princípio da segurança dos atos jurisdicionais. In: TORRES, Ricardo Lobo; KATAOBA, Eduardo Takemi; GALDINO, Flavio (Org.). Dicionário de princípios jurídicos. Rio de Janeiro: Elsevier, 2011.

. Teoria geral do processo: curso de processo civil. 4. ed. rev. e atual. São Paulo: Ed. Revista dos Tribunais, 2010. v. 1.

Tutela antecipatória e julgamento antecipado: parte incontroversa da demanda. 5. ed. rev. atual. São Paulo: Ed. Revista dos Tribunais, 2002.

; ARENHART, Sérgio Cruz. Curso de processo civil: processo de conhecimento. São Paulo: Ed. Revista dos Tribunais, 2007. 2 v.

MARQUES, José Frederico. Manual de direito processual civil. Campinas: Bookseller, 1997. v. 3, p. 66.

MARTINS, Nei Frederico Cano. Os princípios do direito do trabalho e a flexibilização ou desregulamentação. Revista da Faculdade de Direito de São Bernardo do Campo, São Bernardo do Campo, v. 6, t. 1, p. 276, 2000.

MARTINS FILHO, Ives Gandra da Silva. O critério de transcendência no recurso de revista. Brasília. Disponível em <http://www.planalto.gov.br/ccivil_03/revista/Rev_20/artigos/IvesGandra_rev20.htm>. Acesso em 04 jun. 2010.

MEDEIROS, Luiz Cézar. Princípio do devido processo legal: procedural due process e substantive due process. In: CRUZ, Paulo Márcio; GOMES, Rogério Zuel et al. Princípios constitucionais e direitos fundamentais: contribuições ao debate. Curitiba: Juruá, 2007.

MEDINA, Paulo Roberto Gôuvea. As reformas do CPC. Disponível em: <http://www.oab.org.br/oabEd./users/revista/1205506460174218181901.pdf>. Acesso em 15 nov. 2010. 
MEDINA, Paulo Roberto de Gouvêa. Sentença emprestada: uma nova figura processual. Revista de Processo, São Paulo, n. 135, 2006.

MEIRELLES, Hely Lopes. Mandado de segurança. 27. ed. São Paulo: Malheiros Ed., 2004.

MELlo, Celso Antônio Bandeira de. O conteúdo jurídico do princípio da igualdade. 3. ed. São Paulo: Malheiros Ed., 1995.

MENDES, Gilmar Ferreira; COELHO, Inocêncio Mártires; BRANCO, Paulo Gustavo Bonet. Curso de direito constitucional. 2. ed. rev. e atual. São Paulo: Saraiva, 2008.

MENEZES, Iure Pedroza. O novo art. 285-A do CPC: reflexões acerca de sua constitucionalidade. Jus Navigandi, Teresina, ano 12, n. 1479, 20 jul. 2007. Disponível em: $<$ http://jus.com.br/revista/texto/10165>. Acesso em: 5 nov. 2012.

MESQUITA, Gil Ferreira de. Princípios do contraditório e da ampla defesa no processo civil brasileiro. São Paulo: Juarez de Oliveira, 2003.

MINISTROS do STJ destacam pontos críticos do novo CPC. Migalhas. Disponível em: $<$ http://www.migalhas.com.br/Quentes/17,MI162264,101048-

Ministros+do+STJ+destacam+pontos+criticos+do+novo+CPC>. Acesso em: 01 dez. 2012.

MIRANDA, Gilson Delgado. Dos embargos de declaração. In: MARCATO, Antonio Carlos (Coord.). Código de Processo Civil interpretado. São Paulo: Atlas, 2004.

; PIZZOL, Patricia Miranda. Processo civil: recursos. 5. ed. São Paulo: Atlas, 2006. v. 1.

MITIDIERO, Daniel. A multifuncionalidade do direito fundamental ao contraditório e a improcedência liminar (art. 285-A, CPC): resposta à crítica de José Tesheiner. Revista de Processo, São Paulo, v. 32, n. 144, fev. 2007.

MOLICA, Rogerio. Os processos repetitivos e a celeridade processual. 2010. Tese (Doutorado) - Faculdade de Direito da Universidade de São Paulo, São Paulo, 2010..

MONNERAT, Fábio Victor da Fonte. Primeiras aplicações do art. 285-A do CPC. Revista de Processo, São Paulo, v. 33 n. 157, 2008.

MONTES, Diego Cunha Maeso. O princípio do contraditório e a lei n. 11.277/06 (ART. 285-A DO CPC) - utilização no procedimento da ação rescisória - aplicabilidade na Justiça do Trabalho. Caderno de Doutrina e Jurisprudência da Ematra XV, v. 2, n. 5, p. 253-254, set./out. $2006 . \quad$ Disponível em: $<$ http://bdjur.stj.gov.br/xmlui/bitstream/handle/2011/35317/principio_contraditorio.pdf?seq uence $=1>$. Acesso em: 27 de maio de 2011 . 
MORAES, Alexandre de. Direito constitucional. 21. ed. São Paulo: Atlas, 2007.

NEIVA, José Antonio Lisbôa. Improbidade administrativa: estudo sobre a demanda na ação de conhecimento e cautelar. 2. ed. Rio de Janeiro: Impetus, 2006.

NERY JÚNIOR, Nelson. Princípios do processo na Constituição Federal: processo civil, penal e administrativo. 9. ed. São Paulo: Ed. Revista dos Tribunais, 2009.

Princípios fundamentais: teoria geral dos recursos. São Paulo: Ed. Revista dos Tribunais, 1997.

; NERY, Rosa Maria Andrade. Código de Processo Civil comentado e legislação processual civil extravagante em vigor. 11. ed. São Paulo: Ed. Revista dos Tribunais, 2010.

NEVES, Daniel Amorim Assumpção. Interesse recursal e sucumbência. Disponível em: $<$ http://www.professordanielneves.com.br/artigos/201011151803310.interesseemrecorrer.p df>. Acesso em: 08 nov. 2012.

. Manual de direito processual civil. Rio de Janeiro: Forense; São Paulo: Método, 2009.

. Recurso contra a sentença de improcedência liminar (art. 285-A do CPC) e o juízo de retratação. Revista Dialética de Direito Processual, São Paulo, n. 54, set. 2007.

NOGUEIRA, Daniel Moura. A nova sistemática do processamento e julgamento do recurso especial repetitivo, art. 543-C, do CPC. Revista de Processo, São Paulo, v. 33, n. 164, out. 2008.

NOGUEIRA, Glaucia Assalin. O julgamento parcial: possibilidade de cisão do julgamento de mérito relativamente à parte incontroversa da demanda. Dissertação (Mestrado) - Faculdade de Direito, Universidade de São Paulo. 2009.

OLIVEIRA, Pedro Miranda de. Aspectos polêmicos e atuais dos recursos cíveis e assuntos afins. São Paulo: Ed. Revista dos Tribunais, 2006. (Série Aspectos polêmicos e atuais dos recursos, v.9)..

OLIVEIRA NETO, Olavo de; OLIVEIRA, Patrícia Elias Cozzolino de. Princípio da isonomia. In: OLIVEIRA NETO, Olavo de; LOPES, Maria Elizabeth de Castro (Orgs.). Princípios processuais civis na Constituição. Rio de Janeiro: Elsevier Campus, 2008.

ORIONE NETO, Luiz. Recursos cíveis: teoria geral, princípios fundamentais, dos recursos em espécie, tutela de urgência no âmbito recursal, da ordem dos processos no tribunal. 3 . ed. São Paulo: Saraiva, 2009. 
PARENTE, Eduardo de Albuquerque. A súmula impeditiva de recursos e o sistema de precedentes. In: CARMONA, Carlos Alberto (Coord.). Reflexões sobre a reforma do Código de Processo Civil: estudos em homenagem a Ada Pellegrini Grinover, Cândido R. Dinamarco e Kazuo Watanabe. São Paulo: Atlas, 2007.

PELEJA JÚNIOR, Antônio Veloso. Reformas do Código de Processo Civil e novos mecanismos de acesso à justiça. Curitiba: Juruá, 2010.

PINTO, Fernanda Guedes. As ações repetitivas e o novel art. 285-A do CPC (racionalização para as demandas de massa). Revista de Processo, São Paulo, v. 32 n. 150, p. 131, ago. 2007.

PINTO, Nelson Luiz. Manual dos recursos cíveis. São Paulo: Malheiros Ed., 2002.

PISSURNO, Marco Antônio Ribas. Primeiras impressões sobre o novo art. 285-a do CPC (Lei $\mathrm{n}^{\circ}$ 11.277/06): alguns aspectos práticos da sentença de improcedência liminar em "processos repetitivos". Jus Navigandi, Teresina, ano 10, n. 993, 21 mar. 2006. Disponível em: <http://jus2.uol.com.br/doutrina/texto.asp?id=8128>. Acesso em: 13 maio 2010.

PISTORI, Gerson Lacerda. A efetividade como um princípio orientador. Revista do Tribunal Regional do Trabalho da 15 ${ }^{a}$ Região, Campinas, São Paulo, n. 13, 2000. Disponível em: <http://trt15.gov.br/escola_da_magistratura/Rev13Art3.pdf>. Acesso em: 4 dez. 2008.

POITTEVIN, Ana Laura González. O art. 285-A do CPC e os embargos de declaração. In: MEDINA, José Miguel Garcia et al (Coord.). Os poderes do juiz e o controle das decisões judiciais: estudos em homenagem à Professora Teresa Arruda Alvim Wambier. São Paulo: Ed. Revista dos Tribunais, 2008.

PORTANOVA, Rui. Princípios do processo civil. 6. ed. Porto Alegre: Livr. do Advogado, 2005.

PORTUGAL. Código de Processo Civil. Disponível em: $<$ http://www.dgpj.mj.pt/sections/leis-da-justica/livro-iii-leis-civis-e/consolidacaoprocesso/codigo-processocivil/downloadFile/file/CODIGO_PROCESSO_CIVIL_VF.pdf?nocache=1286970369.12>. Acesso em: 21 dez. 2012.

PUOLI, José Carlos Baptista. Responsabilidade civil do promotor de justiça na tutela a interesses metaindividuais. Tese (Doutorado) - Faculdade de Direito da Universidade de São Paulo, São Paulo, 2005. 
REDONDO, Bruno Garcia. Sentença parcial de mérito e apelação em autos suplementares. Revista de Processo, Sâo Paulo, v. 33, n. 160, jun. 2008.

RESTIFFE, Paulo Sérgio. Reforma do CPC: modificação das regras recursais e julgamento liminar definitivo em processos repetitivos - leis 11.276 e 11.277. Revista Dialética de Direito Processual, São Paulo, n. 37, abr. 2006.

ROCHA, Cármen Lúcia Antunes. O princípio constitucional da igualdade. Belo Horizonte: Ed. Lê, 1990.

(Coord.). Constituição e segurança jurídica: direito adquirido, ato jurídico perfeito e coisa julgada. Belo Horizonte: Fórum, 2004.

ROCHA, Cesar Asfor. Breves reflexões críticas sobre a ação de improbidade administrativa. Ribeirão Preto: Migalhas, 2012.

RODRIGUES, Marcelo Abelha. Manual de direito processual civil. São Paulo: Ed. Revista dos Tribunais, 2008.

. Manual de direito processual: teoria geral: premissas e institutos fundamentais, relação jurídica; procedimentos em $1^{\circ}$ e $2^{\circ}$ graus; recursos; execução; tutela de urgência. 4. ed. reform., atual. e ampl. São Paulo: Ed. Revista dos Tribunais, 2008.

RODRIGUES, Ruy Fernando Zoch. Antecipação de tutela sem o requisito da urgência em ações repetitivas. 2009. Tese (Doutorado) - Faculdade de Direito, Universidade de São Paulo, São Paulo, 2009.

RODRIGUES, Viviane Siqueira. O processo coletivo para a defesa dos direitos individuais homogêneos. 2012. Dissertação (Mestrado) _ Faculdade de Direito, Universidade de São Paulo, São Paulo, 2012.

RODRIGUES NETTO, Nelson. Cognição limitada do mérito da apelação pelo juízo de primeiro grau (art. 518, § $1^{\circ}$, do CPC). In: NERY JÚNIOR, Nelson; WAMBIER, Teresa Arruda Alvim (Coord.). Aspectos polêmicos e atuais dos recursos cíveis e assuntos afins. São Paulo: Ed. Revista dos Tribunais, 2007. v. 11, p. 238-245.

SÁ, Djanira Maria Radamés de; PIMENTA, Haroldo. Reflexões iniciais sobre o art. 285-A do Código de Processo Civil. Revista de Processo, São Paulo, v. 31 n. 133, p. 147-148, mar. 2006.

SADEK, Maria Tereza. Entrevista concedida por Maria Tereza Sadek a Aline Pinheiro. Consultor Jurídico. Disponível em: <http://www.conjur.com.br/2006-jan08/justica_trabalha_nao_chega_cidadao>. Acesso em: 28 nov. 2012. 
SALlES, Carlos Alberto de. A legitimação do Ministério Público para defesa de direitos e garantias constitucionais. 1992. Dissertação (Mestrado) - Faculdade de Direito, Universidade de São Paulo. São Paulo, 1992.

- Mecanismos alternativos de solução de controvérsias e acesso à justiça: a inafastabilidade da tutela jurisdicional recolocada. In: FUX, Luiz; NERY JR., Nelson; WAMBIER, Tereza Arruda Alvim (Coiord.). Processo e Constituição: estudos em homenagem ao Professor José Carlos Barbosa Moreira. São Paulo: Ed. Revista dos Tribunais, 2006.

SANSEVERINO, Milton; KOMATSU, Roque. A citação no direito processual civil. São Paulo: Ed. Revista dos Tribunais, 1977.

SANT'ANNA, Paulo Afonso de Souza. Ações repetitivas e julgamento liminar (art. 285-A do CPC). Revista Dialética de Direito Processual, São Paulo, n. 70, p. 109-110, jan. 2009.

SANTOS, Ernane Fidélis dos. Manual de direito processual civil: processo de conhecimento. 13. ed. São Paulo: Saraiva, 2009. v. 1.

. Manual de direito processual civil: processo de conhecimento. 14. ed. São Paulo: Saraiva, 2010. v. 1.

SANTOS, Ernane Fidélis dos. As reformas de 2005 e 2006 do Código de Processo Civil. 2. ed. São Paulo: Saraiva, 2006.

SANTOS, Gustavo Martins dos. A sentença liminar do artigo 285-A do CPC e a celeridade processual: uma abordagem à luz dos princípios da isonomia, do acesso à justiça e do devido processo legal. Revista da Seção Judiciária do Rio de Janeiro, Rio de Janeiro, n. 26, p. 72, dez. 2009.

SARMENTO, Daniel. Livres e iguais: estudos de direito constitucional. Rio de Janeiro: Lumen Juris Ed., 2006.

SATO, Priscila Kei. Jurisprudência (Pre) Dominante. NERY JÚNIOR, Nelson; WAMBIER, Teresa Arruda Alvim (Coords.). Aspectos polêmicos e atuais dos recursos. São Paulo: Ed. Revista dos Tribunais, 2000.

SCHOUERI, Luís Eduardo. Segurança na ordem tributária nacional e internacional: tributação do comércio exterior. In: II CONGRESSO NACIONAL DE ESTUDOS TRIBUTÁRIOS: [segurança jurídica na tributação e estado de direito]. Congresso Nacional de Estudos Tributários (2.: 2004: São Paulo, SP). Coordenação: Eurico Marcos Diniz de Santi. São Paulo: Noeses, 2005. p. 375-406. 
SICA, Heitor Vitor Mendonça. Recurso intempestivo por prematuridade? In: NERY JÚNIOR, Nelson; WAMBIER, Teresa Arruda Alvim (Coord.). Aspectos polêmicos e atuais dos recursos cíveis e assuntos afins. São Paulo: Ed. Revista dos Tribunais, 2007. v. 11.

SILVA, Almiro do Couto. O princípio da segurança jurídica (proteção à confiança) no direito público brasileiro e o direito da administração pública de anular seus próprios atos administrativos: o prazo decadencial do art. 54 da Lei do Processo Administrativo da União (Lei n ${ }^{\circ}$ 9.784/99). Revista da Procuradoria-Geral do Estado [do Rio Grande do Sul], Porto Alegre, v. 27, n. 57, p. 33-77, 2004. Disponível em $<$ http://www.pge.rs.gov.br/upload/revista_pge_57_sup.pdf>. Acesso em: 30 out. 2012.

Princípios da legalidade da administração pública e da segurança jurídica no Estado de direito contemporâneo. Revista de Direito Público, São Paulo, v. 20 n. 84, p. 4663, out./dez. 1987.

SILVA, Bruno Freire e. Ação rescisória. Curitiba: Juruá, 2005.

SILVA, José Afonso da. Da Constituição e segurança jurídica. Fórum Administrativo: Direito Público, Belo Horizonte, v. 6, n. 59, p. 6653-6661, jan. 2006.

SILVA, Júlia Lenzi; PEREIRA NETTO, Juliana Presotto. Digressões acerca do princípio da igualdade enquanto pressuposto de existência do devido processo legal e a questão afeta ao exercício do jus postulandi nos juizados especiais federais. Revista da Faculdade de Direito do Sul de Minas (eletrônica), Pouso Alegre, v. 27 n. 1, p. 217-242, jan./jun. 2011 Disponível em: <http://www.fdsm.edu.br/Revista/Volume27_1/Vol271_10.pdf>. Acesso em: 24 set. 2012.

SILVA, Ovídio A. Baptista da. Curso de processo civil: processo de conhecimento. 7. ed. Rio de Janeiro: Forense, 2005. v. 1.

SILVA, Paulo Eduardo Alves da. Gerenciamento de processos. São Paulo: Saraiva, 2010.

SILVA, Ricardo Alexandre da. Anotações sobre o artigo 285-A do Código de Processo Civil. In: ABREU, Pedro Manoel; OLIVEIRA, Pedro Miranda de (Coords.). Direito e processo: estudos em homenagem ao desembargador Norberto Ungaretti. Florianópolis: Conceito, 2007.

SLAIBI FILHO, Nagib. Notas sobre o art. 557 do CPC. Competência do relator de prover $e$ de negar seguimento a recurso. Jus Navigandi, Teresina, ano 7, n. 62, fev. 2003. Disponível em: <http://jus2.uol.com.br/doutrina/texto.asp?id=3792>. Acesso em: 11 nov. 2007. 
STRENGER, Guilherme Gonçalves. A constitucionalidade nos julgamentos de mérito, sem citação. São Paulo: LTr, 2010.

TARTUCE, Fernanda. Igualdade e vulnerabilibidade no processo civil. Rio de Janeiro: Forense, 2012.

TESHEINER, José Maria. Eficácia da sentença e coisa julgada no processo civil. São Paulo: Ed. Revista dos Tribunais, 2001.

THEODORO JÚNIOR, Humberto. Curso de direito processual civil. 36. ed. Rio de Janeiro: Forense, 2006. v. 3.

- Curso de direito processual civil: teoria geral do direito processual civil e processo de conhecimento. 52. ed. Rio de Janeiro: Forense, 2011. v. 1.

A onda reformista do Direito Positivo e suas implicações com o princípio da segurança jurídica. Revista de Doutrina da $4^{a}$ Região. Porto Alegre, ano 24, n. 14, set. $2006 . \quad$ Disponível em: <http://www.revistadoutrina.trf4.jus.br/index.htm?http://www.revistadoutrina.trf4.jus.br/ar tigos/edicao014/Humberto_Junior.htm>. Acesso em: 30 out. 2012.

VIANA, Ulisses Schwarz. A repercussão geral e a Verfassungsbeschwerde. Revista Jurídica Consulex, ano 13, n. 290, p. 51-53, 15 fev. 2009.

VIGLIAR, José Marcelo Menezes. Litigiosidade contida (e o contigenciamento da litigiosidade). In: SALLES, Carlos Alberto de (Coord.). As grandes transformações do processo civil brasileiro: homenagem ao professor Kazuo Watanabe. São Paulo: Quartier Latin, 2009. p. 49-66.

WAMBIER, Luiz Rodrigues. Uma proposta em torno do Conceito de Jurisprudência Dominante. Revista de Processo. São Paulo, v. 25 n. 100, p. 85, out./dez. 2000.

; WAMBIER, Teresa Arruda Alvim; MEDINA, José Miguel Garcia. Breves comentários à nova sistemática processual civil 2. São Paulo: Ed. Revista dos Tribunais, 2006.

WAMBIER, Teresa Arruda Alvim. Nulidades do processo e da sentença. 6. ed. São Paulo: Ed. Revista dos Tribunais, 2007.

O óbvio que não se vê: a nova forma do princípio da fungibilidade. Migalhas, n. 1437, $2006 . \quad$ Disponível em: <http://www.migalhas.com.br/mostra_noticia_articuladas.aspx?cod=25047> Acesso em: 13 de maio de 2010. 
WAMBIER, Teresa Arruda Alvim. Questões de fato, conceito vago e a sua controlabilidade através de recurso especial. In: WAMBIER, Teresa Arruda Alvim. Aspectos polêmicos e atuais do recurso especial e do recurso extraordinário. São Paulo: Ed. Revista dos Tribunais, 1997.

WATANABE, Kazuo. Acesso à justiça e sociedade moderna. In: DINAMARCO, Candido Rangel; GRINOVER, Ada Pellegrini; WATANABE, Kazuo. (Orgs.). Participação e processo. São Paulo: Ed. Revista dos Tribunais, 1988. p. 128-135.

. Cognição no processo civil. 4. ed. São Paulo: Saraiva, 2012.

XAVIER, José Tadeu Neves. Julgamento de improcedência prima facie em ações repetitivas na sistemática processual civil atual e no contexto do projeto de novo Código de Processo Civil. Revista Jurídica. Sapucaia do Sul, v. 59, n. 404, p. 11-44, jun. 2011.

YARSHELL, Flávio Luiz. Antecipação da prova sem o requisito da urgência e direito autônomo à prova. São Paulo: Malheiros Ed., 2009.

Indeferimento da inicial e improcedência da demanda? Carta Forense. Disponível

em: $\quad<$ http://www.cartaforense.com.br/conteudo/colunas/indeferimento-da-inicial-eimprocedencia-da-demanda/60>. Acesso em: 25 out. 2012.

YOSHIKAWA, Eduardo Henrique de Oliveira. Execução extrajudicial e devido processo legal. São Paulo: Atlas, 2010. 